\title{
EXPLORING FACTORS THAT MAY INFLUENCE ONTARIO NURSE PRACTITIONERS' PATIENT PANEL SIZE IN PRIMARY HEALTHCARE SETTINGS
}

\author{
By \\ Nicole Bennewies \\ BScN, Western University, 2013 \\ A thesis \\ Presented to Ryerson University \\ In partial fulfillment of the \\ requirements for the degree of \\ Master of Nursing \\ in the program of Nursing \\ Toronto, Ontario, Canada, 2016 \\ (C) Nicole Bennewies, 2016
}




\section{AUTHOR'S DECLARATION FOR ELECTRONIC SUBMISSION OF A THESIS}

I hereby declare that I am the sole author of this thesis. This is a true copy of the thesis, including any required final revisions, as accepted by my examiners. I authorize Ryerson University to lend this thesis to other institutions or individuals for the purpose of scholarly research. I further authorize Ryerson University to reproduce this thesis by photocopying or by other means, in total or in part, at the request of other institutions or individuals for the purpose of scholarly research. I understand that my thesis may be made electronically available to the public. 


\begin{abstract}
Exploring Factors that May Influence Ontario Nurse Practitioners' Patient Panel Size in Primary Healthcare Settings

(C) Nicole Bennewies, 2016

Master of Nursing

Ryerson University

Limited knowledge exists about the factors that may influence nurse practitioner (NP) patient panel size. Patient panel size refers to the number of patients for whom a NP is their usual care provider. Increased knowledge of these factors may improve patient care, NP practice, and primary health care (PHC) workforce planning. Two hundred and eighty-three NPs working in Ontario PHC were surveyed to explore patient, NP, and organizational factors that may influence NP patient panel size. Three factors were associated with NP panel size. Higher percentages of certain health conditions and/or longer appointment time for multi-morbid and palliative care were associated with smaller NP patient panel size. NPs who worked more hours per week had larger patient panels. Also, the PHC practice model was related to NP patient panel size, which was largest in NP-led clinics. Decision makers can use these findings to support optimization of NP patient panel size.
\end{abstract}




\section{Acknowledgements}

I would like to sincerely thank Dr. Faith Donald whose wisdom and expertise guided me through the process of organizing my thoughts into a meaningful written work. Faith was a supportive mentor, always kind and respectful, and challenged me to think more critically. Her guidance and support has provided me with confidence in the skills I have learned that I can extend into the next stage of my career.

I would also like to extend my thanks to my thesis committee, Dr. Heather Beanlands and Dr. Souraya Sidani. Their thoughtful feedback, statistical expertise, and unique perspectives were very appreciated and added tremendous value to the final product.

Special thanks to my family and friends who supported and encouraged me on this academic journey, I could not have done it without you. 


\section{Table of Contents}

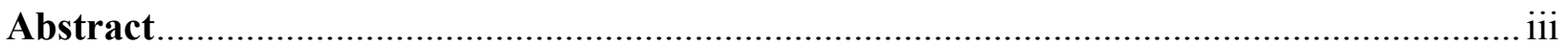

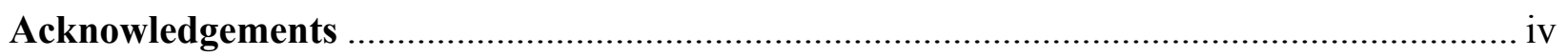

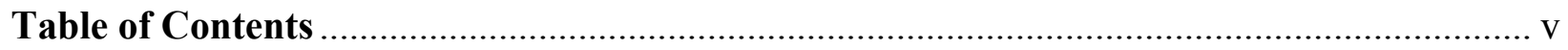

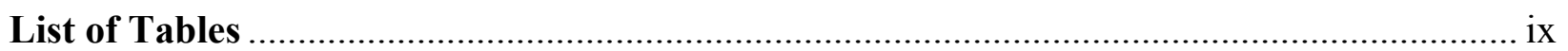

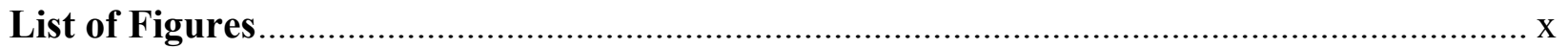

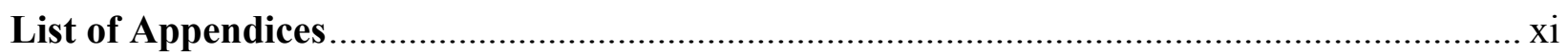

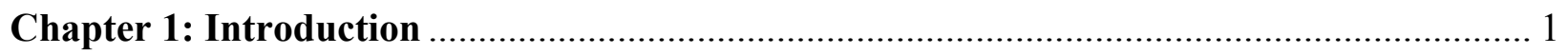

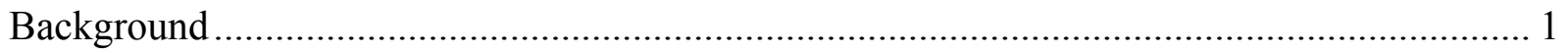

Problem Statement ........................................................................................................ 5

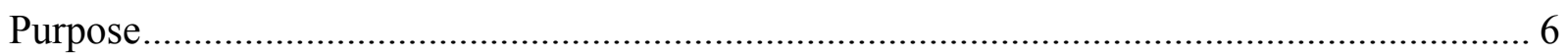

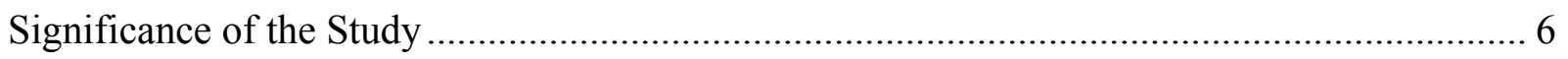

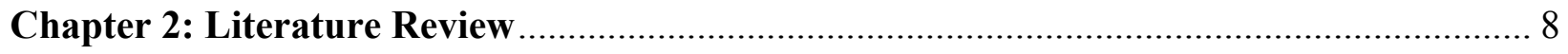

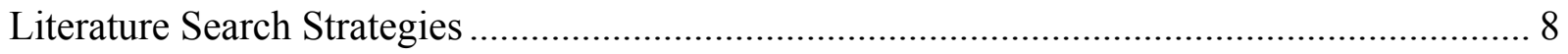

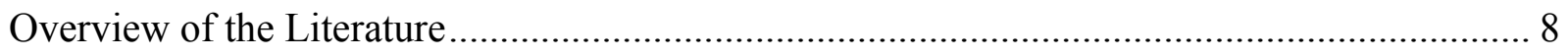

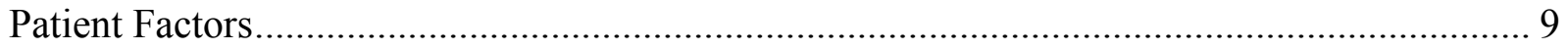

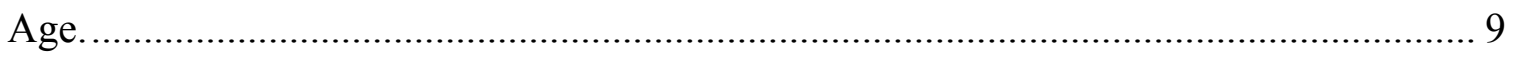

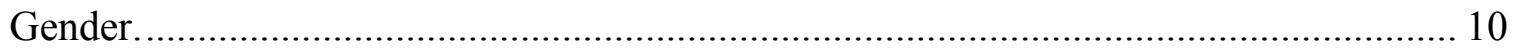

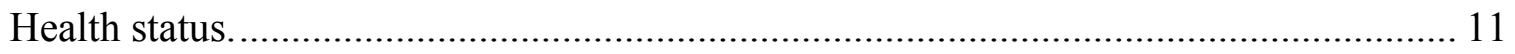

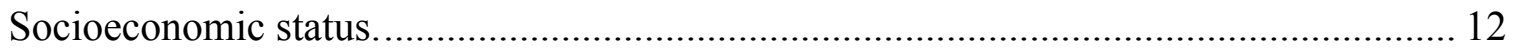

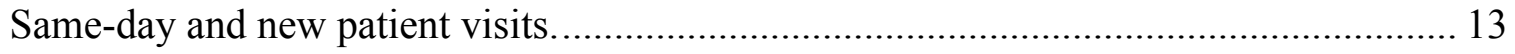

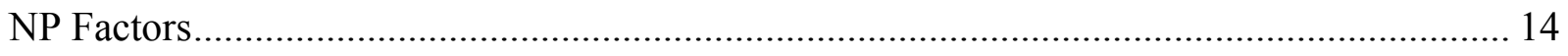

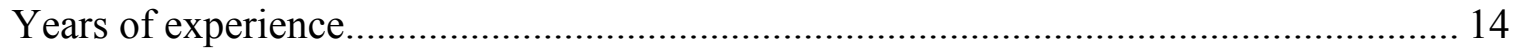




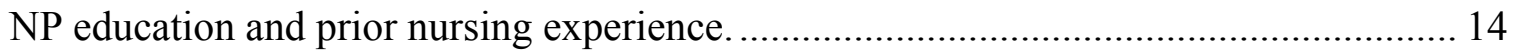

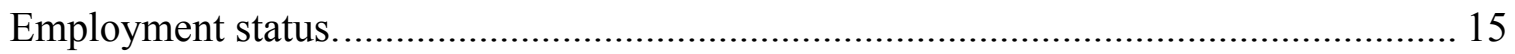

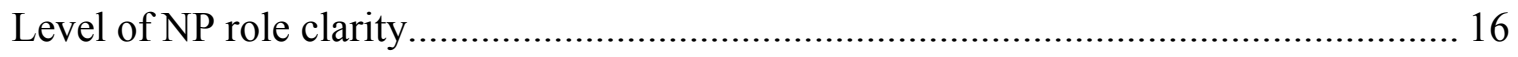

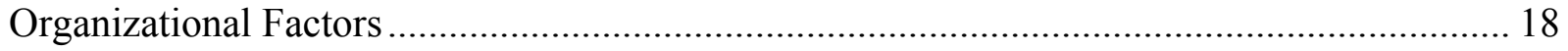

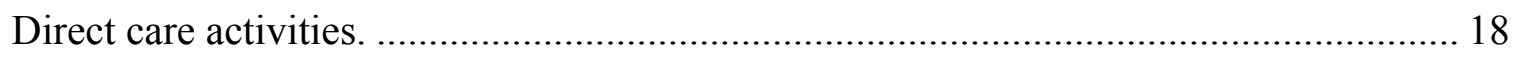

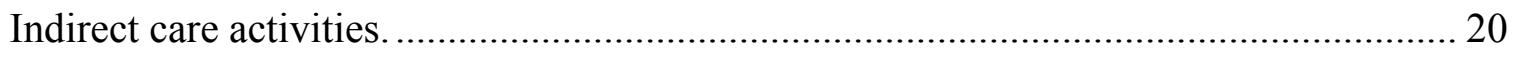

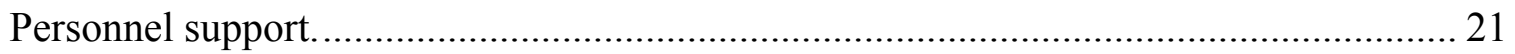

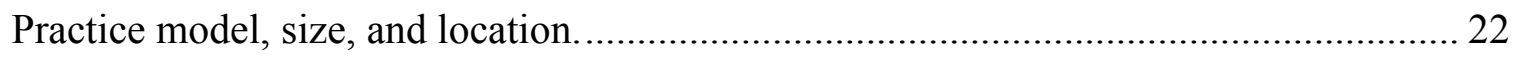

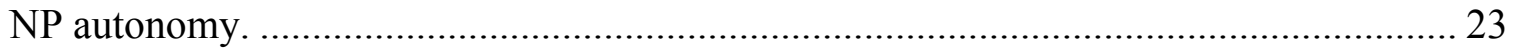

Interdisciplinary team and NP-physician collaboration....................................... 25

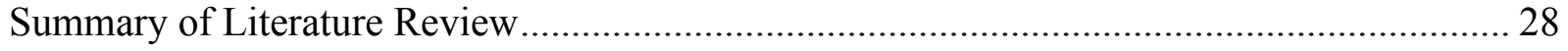

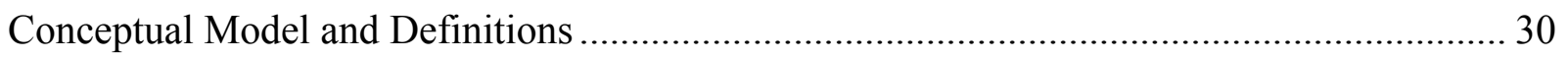

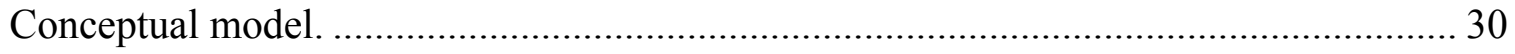

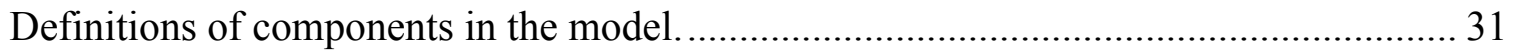

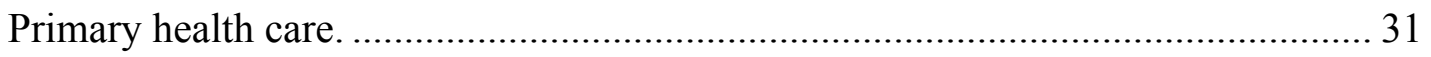

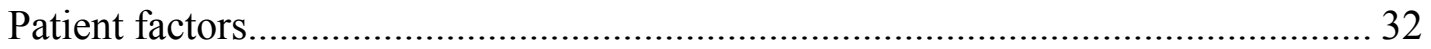

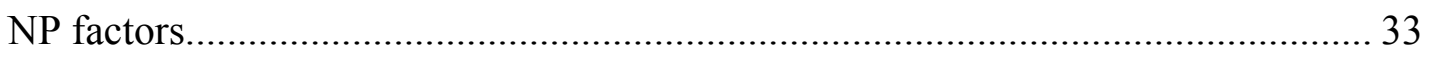

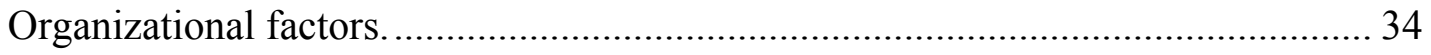

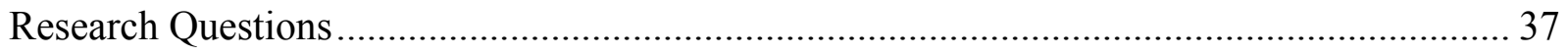

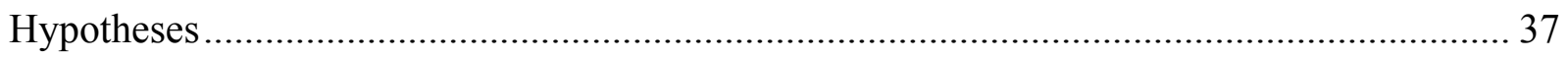

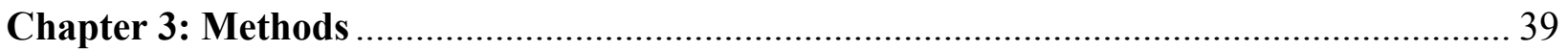

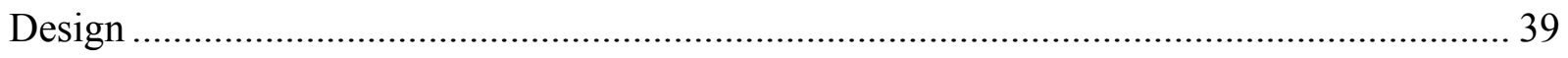

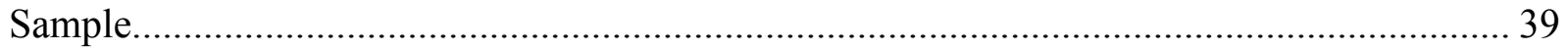


Sample Size, Power, and Effect Size .................................................................................. 40

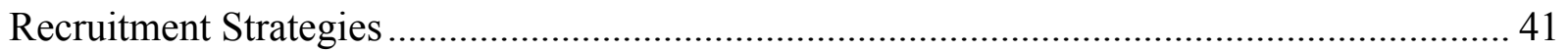

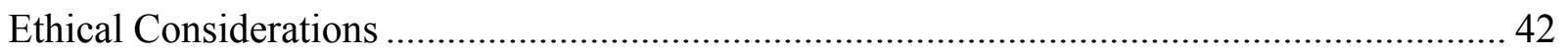

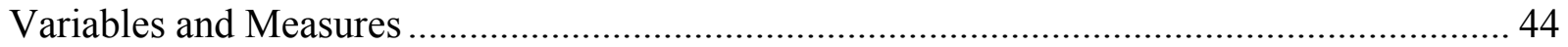

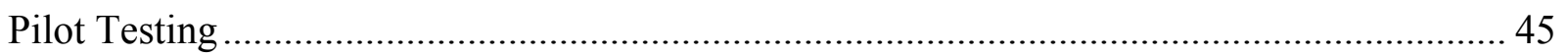

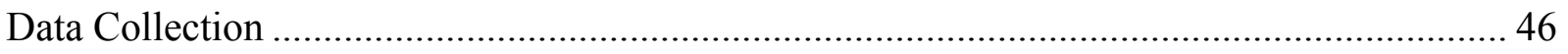

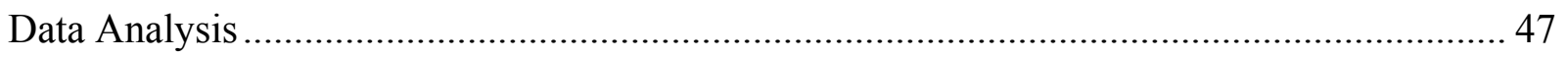

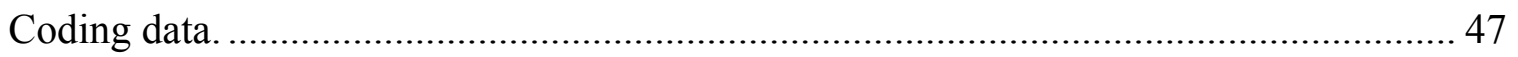

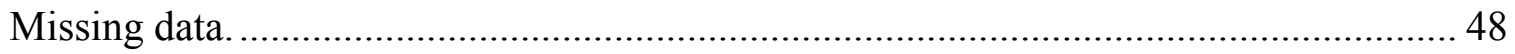

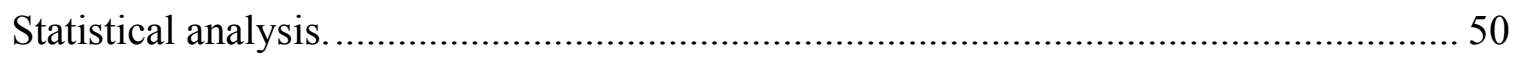

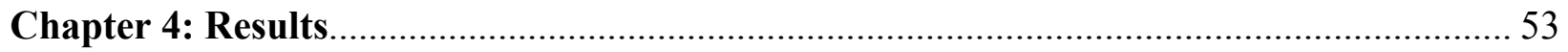

Sample

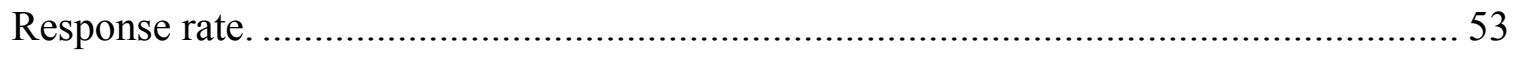

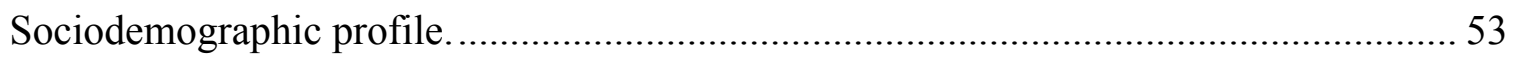

Findings for Patient, NP, and Organizational Factors …………………............................ 55

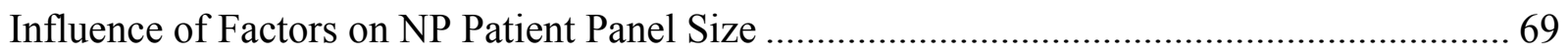

Analysis of NP Patient Panel Size by PHC Practice Model ..................................................... 69

Bivariate Relationships Between Factors and NP Patient Panel Size...................................... 72

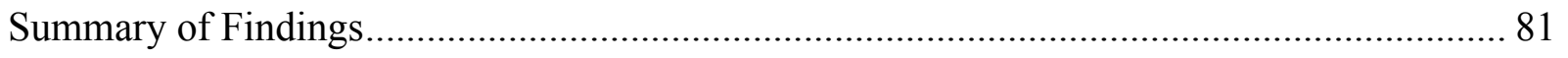

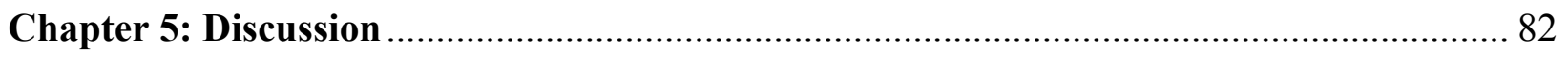

Representativeness of the Sample..................................................................................... 82

NP Patient Panel Size

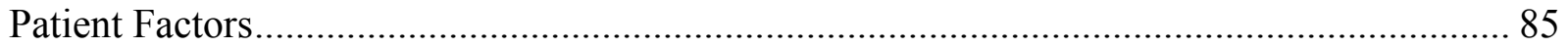




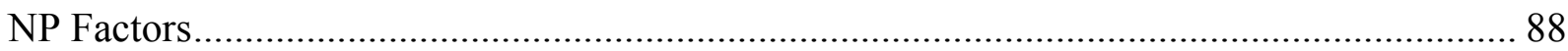

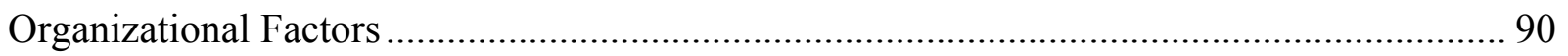

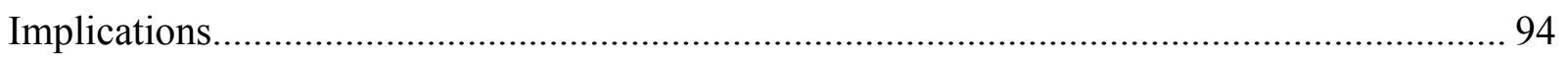

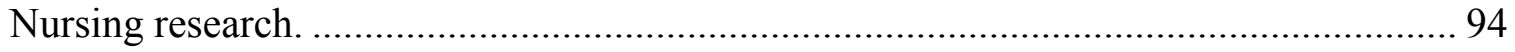

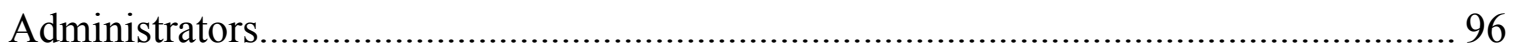

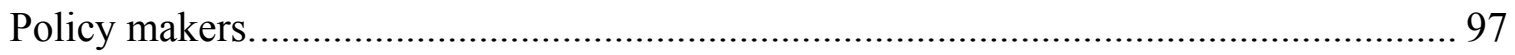

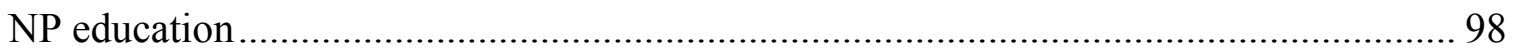

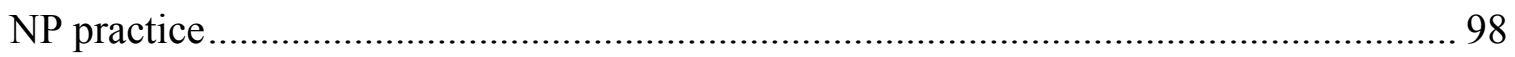

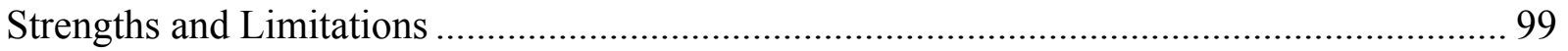

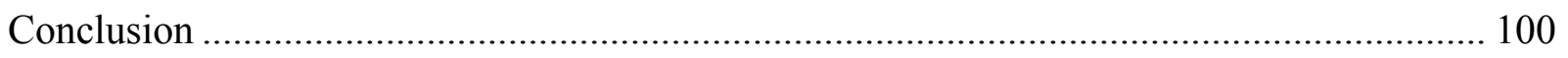

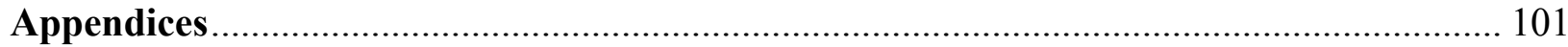

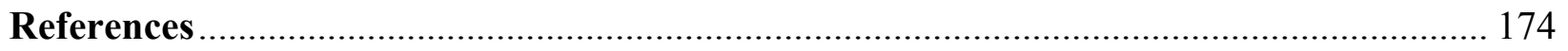




\section{List of Tables}

Table 1. Demographic Characteristics of NP Respondents ..................................................... 54

Table 2. Characteristics of Patients Most Commonly Cared for by NPs................................ 56

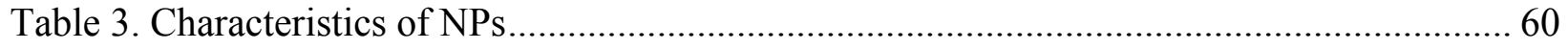

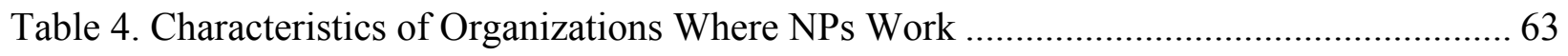

Table 5. Characteristics of NP Patient Panel Size .................................................................. 68

Table 6. PHC Practice Model and Existence of Independent NP Patient Panel Relationship..... 71

Table 7. Patient Factors and NP Patient Panel Size Correlation............................................. 74

Table 8. NP Factors and NP Patient Panel Size Correlation................................................. 76

Table 9. Organizational Factors and NP Patient Panel Size Correlation .................................. 79 


\section{List of Figures}

Figure 1. Conceptual Model for NP Patient Panel Size................................................................ 31

Figure 2. Distribution of NP Patient Panel Size by PHC Practice Model .................................... 80 


\section{List of Appendices}

Appendix A. Literature Review Search Terms ....................................................................... 101

Appendix B. Summary of Literature Examining Patient Factors .............................................. 102

Appendix C. Summary of Literature Examining NP Factors .................................................... 117

Appendix D. Summary of Literature Examining Organizational Factors .................................. 127

Appendix E. Flyer for Primary Care Today Conference ............................................................. 159

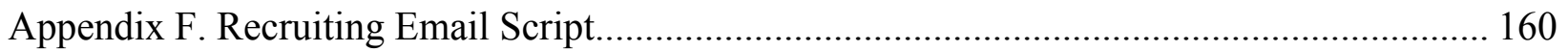

Appendix G. Ryerson Ethics Review Board Approval Letter ................................................... 161

Appendix H. Cover Letter for Province-wide Questionnaire ……............................................. 162

Appendix I. Description of Variables by Question................................................................. 163

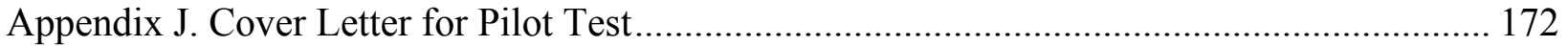

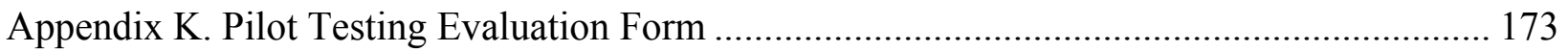




\section{Chapter 1: Introduction}

\section{Background}

Primary healthcare (PHC) in Ontario has become increasingly complex. With healthcare needs intensifying due to an aging population, chronic illness on the rise, and increasing quality of care demands from patients and their families, the healthcare system faces amplified costs and responsibilities (Kaasalainen et al., 2010). New models of care including family health teams (FHTs) and nurse practitioner-led clinics (NPLCs) are currently being funded by the Ontario Ministry of Health and Long Term Care (MOHLTC) as one solution to increase access to quality PHC services while controlling costs. However, with increasing patient complexity and multiple models of care, there is concern around how various healthcare professional roles fit into interdisciplinary teams (Donald et al., 2010; Kaasalainen et al., 2010). Questions around accountability and the roles and responsibilities of healthcare providers in optimizing patient care and health outcomes have also arisen. Specifically, debate exists around what activities, responsibilities, and workload factors influence the nurse practitioner (NP) role, and the ability of NPs to care for patients (DiCicco-Bloom \& Cunningham, 2015; Donald et al., 2010).

NPs are advanced practice nurses with additional education, experience and competencies that allow them to diagnose, order and interpret diagnostic tests, prescribe some medications, and perform specific procedures (College of Nurses of Ontario [CNO], 2011). NPs' expanded scope of practice is recognized to have some overlap with that of family physicians in PHC, resulting in similar roles and responsibilities (Donald et al., 2010; Marchildon, 2005). For example, both NPs and family physicians in PHC focus on chronic disease monitoring and management, health promotion, disease prevention, and the diagnosis and treatment of common acute illnesses (Donald et al., 2010). Historically, NPs were introduced into the Canadian 
healthcare system to fill the need for family physicians in rural areas. Over time, the NP role has evolved into a collaborative partnership with both family physicians and other PHC professionals to meet complex patient needs (DiCenso et al., 2010; Kaasalainen et al., 2010). Strong collaborative relationships have been developed between NPs and family physicians to negotiate shared areas of practice (Marchildon, 2005). NPs now practice closely with family physicians in a variety of PHC settings including FHTs, community health centers (CHCs), Aboriginal health access centers (AHACs), NPLCs, and family physician offices.

Research has demonstrated that NPs provide continuity of care, enhance education and emotional support for patients and families, and facilitate collaboration among interdisciplinary teams (Kaasalainen et al., 2010; Marchildon, 2005). In addition, it has been well-documented internationally that NPs are capable of providing safe and effective PHC to patients with equal and sometimes better health outcomes than patients seen by family physicians (Dierick-van Daele, Metsemakers, Derckx, Spreeuwenberg, \& Vrijhoef, 2009; Donald et al., 2014; Horrocks et al., 2002; Kuo, Chen, Baillargeon, Raji, \& Goodwin, 2015; Martin-Misener et al., 2015; Poghosyan, Boyd, \& Knutson, 2014; Swan, Ferguson, Chang, Larson, \& Smaldone, 2015). Patient ratings of satisfaction have also been consistently high for NP care (Parker et al., 2013; Swan et al., 2015). Moreover, it has been noted that NPs provide holistic care, such as providing written instructions, health education, and family-centred care, thereby creating a positive patient experience (Jennings et al., 2008; Mayo-Bruinsma, Hogg, Taljaard, Dahrouge, 2013). In addition, NPs have been shown to provide increased access to PHC services. For example, DiCenso et al. (2010) discussed the case of Sudbury, Ontario, where many residents did not have access to a regular family physician. The implementation of a NPLC allowed six full-time NPs to provide PHC access to approximately 4,800 patients, which improved patients' access to care, 
satisfaction, and health outcomes (DiCenso et al., 2010). The effectiveness of the NP role in patient care is well-documented in the literature.

However, with much of the literature focusing on NP effectiveness in both primary and acute care settings, there has been little focus on what activities, responsibilities, workload, and productivity factors influence the NP role and the ability of NPs to care for patients. Two of these factors, workload and productivity, are highly interconnected concepts. Workload refers to the amount of care allocated to patients based on an assessment of their needs and the care they require (Canadian Nurses Association [CNA], 2004). Productivity refers to the efficiency of work completed during a specific period of time (Glenngård, 2013; Rhoads, Ferguson, \& Langford, 2006).

Murray, Davies, and Boushon (2007) found that workload and productivity are related to patient panel size, i.e., the number of patients under the care of a specific primary care provider (PCP). In recent years, the concept of NP patient panel size has gained the attention of policy makers. This attention is in part due to NPs' integral role in PHC interdisciplinary teams and to evidence indicating that patient panel size is a way to measure the workload and productivity of family physicians (The College of Family Physicians Canada [CFPC], 2012). Muldoon, Dahrouge, Russell, Hogg, and Ward (2012) in Ontario and CFPC (2012) in Canada first identified the concept of patient panel size for physicians and indicated other PCPs could also use this concept. However, patient panel size is a relatively new term for NPs in Ontario, and accurate measures to determine NP patient panel size have not been developed. Several factors could account for the complexity of estimating patient panel size for NPs, including: diverse patient populations; the varied settings in which NPs work; participation in activities outside a typical clinic setting, such as shelter visits, home visits, and travelling between PHC sites; and 
decision makers' inconsistent understanding of NP activities (Morris, MacNeela, Scott, Treacy, \& Hyde, 2007). However, these factors have not yet been studied in order to determine their potential influence on NP patient panel size in Ontario.

There remains a gap in knowledge around factors that may influence NP patient panel size and how these factors may impact the delivery of PHC in Ontario. Furthermore, administrative databases in Ontario are not designed to track NP activities or to link NPs with the patients they care for, as has been done for physicians (Glazier, Zagorski, \& Rayner, 2012). Recently, the Association of Ontario Health Centres has been working with the Institute for Clinical Evaluative Sciences (ICES) to capture data regarding NP care in CHCs and some NPLCs; however, these data are not yet available for all NPs working in PHC settings in Ontario. This lack of data has resulted in uncertainties of what activities, responsibilities, and workloads influence NP patient panel size across the province. This is an important issue, as currently in Ontario there are 2,587 NPs practicing, with 1,897 registered in the PHC designation and over 50 percent of all NPs working in PHC settings (CNO, 2015). With approximately 200 PHCNP graduates per year in Ontario, NPs in PHC are an increasingly large cohort of the health workforce, for which there is limited information about the factors that influence their patient panel size. Yet, developing an appropriate patient panel, consisting of both manageable complexity and number of patients within the context of other responsibilities in PHC, is essential to delivering high quality, consistent, and accessible care (Murray et al., 2007). Similarly, Evans, Schneider, and Barer (2010) describe a clear link between understanding health human resources and high quality patient care.

Research around PHC physician patient panel size has identified some patient, provider, and organization factors that likely influence the determination of physician patient panel size 
(CFPC, 2012; Muldoon et al., 2012). Examples of identified patient factors include health status of patients and demographic characteristics such as age and gender (Muldoon, Rayner, \& Dahrouge, 2013). Various physician provider factors have been identified, including years of experience working in $\mathrm{PHC}$ and at a particular clinic, employment status, and prior education (CFPC, 2012). Some of the identified organizational factors include type of interdisciplinary team within a clinic; availability of support personnel (e.g., clerical); and practice structure, size, model, and location (Muldoon et al., 2012). Because NPs work closely with physicians, and given the overlap in their roles in PHC and similar PHC work environments, these factors may be applicable to the NP practice context and may contribute to NP patient panel size. For example, provider factors can be adapted to specifically refer to the NPs' prior nursing experience and NP experience.

With the increased use of NPs and their demonstrated value to the healthcare system, there is a growing need to further understand the factors that influence NP patient panel size in PHC settings in Ontario. This increased understanding may result in improved healthcare system planning, and more manageable workloads for NPs to achieve better patient health outcomes. Understanding factors that influence NP patient panel size may also aid in improving the use of health human resources, workforce planning (Gorman, 2015), and healthcare team design to promote high quality PHC in Ontario.

\section{Problem Statement}

For NPs, the concept of patient panel size is not well-defined or understood, with limited knowledge about the activities, responsibilities, workload, and productivity factors that may influence NP patient panel size. Health policy makers are currently unclear regarding how the NP role is being used in various PHC settings, and if changes need to be made to the NP role or 
the models in which the role operates. Further exploration of the relevant factors is required to understand their potential influence on patient panel size for NPs practicing in PHC in Ontario.

\section{Purpose}

The purpose of the present study was to explore, from the perspective of NPs, factors at the patient, NP, and organizational levels that may influence NP patient panel size in Ontario PHC settings.

\section{Significance of the Study}

This present study was part of a larger study conducted by Drs. Faith Donald and Ruth Martin-Misener, titled "Measuring Factors that Influence Nurse Practitioner Activities and the Implications for Optimizing NP Patient Panel Size in Primary Healthcare Settings,” where a scoping review was conducted, a time and motion tool was used to track NP daily activities, and interviews were conducted with NPs, physicians, administrators, and receptionists. The present study added to the larger study's findings with NP-specific province-wide data.

Increased knowledge around patient, NP, and organizational factors that influence NP patient panel size in PHC settings is also essential for patients, the nursing profession, the healthcare system, and policy decision makers. Gaining a greater understanding of the types of patients that NPs are treating in PHC settings and their needs may allow for better patient panel size estimation and may ultimately increase access to quality care for patients in PHC. Understanding NP-related factors may promote appropriate workloads for NPs, inform NP graduate education program curriculum, and advance nursing and inter-professional practice. Lastly, by increasing the knowledge of various organizational factors that influence patient panel size, policy makers can understand how these factors are impacting the workplace and wider healthcare system. This knowledge may allow policy makers to create informed decisions 
relating to the allocation of human and financial resources, and potentially lead to improved PHC working conditions. Knowledge about the factors influencing NP patient panel size is needed to further understand how NPs are currently practicing and the workload they experience in order to explore strategies to optimize NP patient panel size. The present study also provides a foundation for future nursing, healthcare, and health workforce studies in Canada to further determine how to make the best use of NPs in PHC settings to continue to improve access to quality care for patients. 


\section{Chapter 2: Literature Review}

In this chapter the empirical literature surrounding patient, NP, and organizational factors is examined in relation to their influence on NP patient panel size in various PHC settings. At the beginning of the chapter, a description of the literature search strategies is presented. The conceptual model that guides the present study is discussed, and key concepts are defined. Research questions and hypotheses are also presented.

\section{Literature Search Strategies}

The literature search was conducted using CINAHL, Medline via Ovid, ProQuest Nursing, Scholars Portal Journals, Proquest Dissertation and Theses, Cochrane Database, and Google Scholar databases. See Appendix A for the search terms used. The searches were limited to English language, from 2000 to 2016 to capture literature relevant to the current context of NP practice. Articles were included in the review if they 1) discussed caseload, workload, and/or patient panels for NPs in community-based PHC settings serving an all-ages population, and 2) were in English. A total of 56 peer-reviewed journal articles met the selection criteria and were examined. Relevant professional and government websites, such as the Ontario MOHLTC were also examined using the same search strategies for relevant information on NP patient panel size, and 11 additional reports were found. In total, 42 articles were international, 20 were from Ontario, and five were from other Canadian provinces. Data extracted from the articles were synthesized to gain an understanding of the topic.

\section{Overview of the Literature}

The literature review process revealed a number of patient, NP, and organizational factors that may influence NP patient panel size. Patient characteristics identified in the literature as likely to impact NP patient panel size included patient demographic factors such as age, gender, 
and socioeconomic status. The health status of patients, whether the patients were new to a clinic or provider, and whether they were a same-day or unscheduled visit were identified as factors likely to impact NP patient panel size. NP-related factors included years of experience, previous nursing experience and education, employment status, and the presence of role clarity for the NP. Lastly, several organizational factors were identified as influential to NP patient panel size. These factors included: time spent in direct and indirect care activities; personnel support; practice model, size and location; NP autonomy; interdisciplinary team; and NP-physician collaboration. These factors are explored further in the next sections.

\section{Patient Factors}

Several patient factors emerged from the literature that may impact NP patient panel size. These were: patient age, gender, health status (e.g., if they presented with an acute illness, chronic illnesses, or multi-morbidities), socioeconomic status, and if the patient was new to a practice, provider, and/or whether she/he was a same-day or unscheduled visit. These patient characteristics are important to consider, as they may affect patient panel size for NPs. See Appendix B for a detailed summary of the literature that examined patient factors.

Age. The impact of patient age on NPs' workload was well documented in Canadian and international studies. Three international studies, Dierick-van Daele et al. (2010) and the Department of Veterans Affairs, Veteran Health Administration (VHA; 2009, 2014), found that increased patient age was associated with an increased workload for the provider. Only one Ontario study specified that clients' age is an important factor to consider when measuring provider workload and estimating patient panel size (Rayner, 2014). Rayner (2014) used the Standardized Adjustment Clinical Group Morbidity Index (SAMI) to understand the average complexity of CHC patients and to estimate patient panel size for providers at CHCs. A SAMI 
score above 1 indicated a client population that was sicker and required more resources than average patients, thus decreasing panel size. A higher proportion of older patients contributed to a score greater than 1 in Ontario CHCs due to multi-morbidities. The findings from this study, however, were exclusive to CHCs in Ontario.

Other studies reported the proportion of patients within different age categories cared for by the NP. Sangster-Gormley et al. (2012) and Roots and MacDonald (2014) found that NPs in British Columbia worked with approximately $42 \%$ adults (patients aged 18 to 64 years) and $32 \%$ seniors (patients aged 65 years and older), and that older patients contributed to an increased workload for the provider. Multiple Ontario studies reported similar proportions of patient ages cared for by NPs (e.g., Koren, Mian, \& Ruckholm, 2010; Mian, Lacarte, \& Koren, 2012; Sloan, Pong, Rukholm, \& Caty, 2006). Dahrouge et al.'s (2014) study found that NPs in these Ontario CHCs included in their study tended to care for younger patients; however, NP patient populations varied across the province. None of the above studies specifically examined the association of patient age with NP patient panel size. Further exploration is needed to understand how different ages impact NP patient panel size.

Gender. Gender was another factor that emerged as important to consider in determining NP patient panel size. International studies indicated that NPs treat a high number of female patients, who often make more frequent visits and have more complex health issues compared to males (Deshefy-Longhi, Swartz, and Grey, 2008; Dierick-van Daele et al., 2010; Hing, Hooker, \& Ashman, 2011; Morgan, Everett, \& Hing, 2015; Oritz, Wan, Meemon, Paek, \& Agiro, 2010; VHA, 2009, 2014). This same finding has also been reported in Ontario studies that have examined a variety of PHC settings (Koren et al., 2010; Rayner, 2014; Shortt, Hogg, Devlin, Russell, \& Muldoon, 2012; Sloan et al., 2006). Rayner (2014) noted that client gender was 
important to consider for measuring provider workload because female gender increased SAMI scores impacting a provider's patient panel size. One Ontario study and one United States (US) study found that female gender influenced provider workload, because female patients required longer procedures, such as physical exams (e.g., pap smears) compared to male patients and made more frequent visits (Bertakis, Azari, Helms, Callahan, \& Robbins, 2000; Canadian Women's Health Network, 2005). These longer procedures and/or more frequent visits can result in females requiring more NP consultation time, thus impacting on available time for additional patients in the panel. Therefore, gender has been identified as an important factor to consider for NP patient panel size. Anecdotal evidence suggests that transgender clients require longer NP consultation time as well. However, there is a lack of literature surrounding transgender influence on NP workload. As such, transgender was included in the present study's questionnaire to explore this gap in knowledge.

Health status. Health status emerged as a prominent factor that impacts NP time and resources. Consistent findings have been reported in the international and Canadian literature indicating that patients with chronic illnesses, including hypertension, diabetes, renal disease, congestive heart failure, mental illness and addiction, and multi-morbidities required more resources, care coordination, and provider time in comparison to those with acute illnesses (Dahrouge et al., 2014; Glazier et al., 2012; Muldoon et al., 2012; Potts, Adams, \& Spadin, 2011; Sangster-Gormley et al., 2012; VHA 2009, 2014; Watts et al., 2009; Way, Jones, Baskerville, \& Busing, 2001). Rayner (2014) found a high prevalence of patients with multi-morbidities in CHCs in Ontario, and highlighted the need to factor multi-morbidities into provider workload. Russell et al. (2009) found a high prevalence of chronic illness across all models of PHC practices in Ontario. Deshefy-Longhi et al. (2008) and Koren et al. (2010) reported that about 
$45 \%$ of patient visits to NPs were focused on acute illnesses and $30 \%$ of patient visits on chronic illnesses. However, patients also often presented with co-occurring chronic and acute illnesses. In contrast, Morgan et al. (2015) found that in the US, NP patient visits were more often for preventive care and less often for chronic care than visits to physicians or physician assistants. The majority of the authors recognized that chronic illness and multi-morbidities impact NP time, as patients with these conditions require more care coordination and resources in comparison to those with acute illnesses.

Socioeconomic status. Patients with low socioeconomic status often require more provider time for health teaching and linking to health resources. Canadian and international literature indicates that lower socioeconomic status increases patients' social concerns and need for care, and requires increased coordination of care among providers; thereby, increasing overall provider workload (Duck, DeLia, \& Cantor, 2001; Glazier et al., 2012; Holcomb, 2000; Muldoon et al., 2012; Oritz et al., 2010; Poghosyan, Lucero, Rauch, \& Berkowitz, 2012; VHA, 2009, 2014). It is well documented that NPs report that the majority of their patients consist of marginalized populations including low-income earners, unemployed persons, people with substance abuse issues, people with mental illness, ethnic minorities, and recent immigrants (Buerhaus, DesRoches, Dittus, \& Donelan, 2015; Donald et al., 2010; Koren et al., 2010; Sloan et al., 2006). Rayner (2014), Dahrouge et al. (2014), and Muldoon et al. (2013) looked specifically at Ontario CHC patient populations and found a high prevalence of poverty, unemployment, and homelessness that impacted provider patient panel size. Dahrouge et al. (2014) specifically reported that CHC patients who tended to be homeless and did not have a postsecondary education were more likely to receive care from a NP. This may influence NP patient panel size, as patients with complex social issues and lower education may require more 
care coordination, more time for health teaching, and more organization of services to enhance access to required community resources. Muldoon et al. (2013) reported that although poor patients generate a higher workload for PHC providers in CHCs, multi-morbidities had more of an impact on provider workload. However, Muldoon et al. (2013) had a strong focus on physician patient panel size, which may differ from that of NPs.

Same-day and new patient visits. Patients who are new to a practice and/or provider, or who present with an appointment made on the same-day or as an unscheduled visit may require more NP time. In such cases, patients may be new to the NP; their health histories may be unknown, and simple issues (e.g., acute ear infection) may require a more comprehensive assessment. Hing et al. (2011) and Glazier et al. (2012) reported that Ontario CHCs are more likely to accept new patients and have a higher number of newcomers, compared to office-based PHC practices. Dahrouge et al. (2014) found that NPs in CHCs accepted and attended to more same-day visits than family physicians. However, these studies did not specify how this increased proportion of same-day visits impacted provider time and workload in relation to NP patient panel size.

Overall, these patient factors need to be further examined in an Ontarian context to understand their prevalence and relation to NP patient panel size in PHC settings. Patient age and gender need to be further examined to understand who NPs care for most often and the association these patient factors may have with NP patient panel size. In addition, understanding how chronic illness and multi-morbidities impact NP patient panel size is important for estimating time and resources required of NPs. Patients' socioeconomic status requires further exploration in relation to NP patient panel size, because those with low socioeconomic status may require more NP time for health teaching and linking to health resources. Lastly, further 
research is needed to understand how same-day and new patient visits impact NP patient panel size. Gaining a greater understanding of these patient factors may allow for patient panel size to be better optimized for NPs in PHC.

\section{NP Factors}

NP-related factors found to be relevant to NP patient panel size included years of experience, educational background, prior nursing experience, employment status, and whether there was role clarity for the NP within the interdisciplinary team. See Appendix C for a detailed summary of the literature that addresses NP-related factors.

Years of experience. This factor included years of experience working as a NP, as well as years of experience a NP had been working in a particular PHC setting; each impacted how quickly patients were assessed and how many patients a NP saw per day. Several international studies identified that the outcomes of patients cared for by novice/beginner NPs with one to five years of experience were similar to those of patients seen by family physicians (Dierick-van Daele et al., 2009; Dierick-van Daele, Steuten, Romeijn, Derckx, and Vrijhoef, 2011; Johnson, 2005; Venning, Durie, Roland, Roberts, \& Leese, 2000). Novice NPs, however, were more likely to ask the patient to return for a follow-up visit and took more time doing consultations. The VHA (2009) also found that NPs newer to a PHC practice may take 12 to 15 months to build a panel of patients, which impacts clinic productivity and NP patient panel size. However, none of these studies were completed in Canada.

NP education and prior nursing experience. Few studies examined NP education and prior nursing experience in PHC in relation to NP patient panel size. Many investigators found that the majority of NPs have a master's degree with NP certification (Koren et al., 2010; MartinMisener et al., 2010; Sangster-Gormley et al., 2012; van Soeren, Hurlock-Chorostecki, Goodwin, 
\& Baker, 2009). Waszynski, Murakami, and Lewis (2000) reported that the process of obtaining a master's degree allowed NPs to develop clinical, interpersonal, and organizational skills. Martin-Misener et al. (2010) further noted that NPs in Nova Scotia had a wide array of prior nursing experience, with a mean of 24 years working as a registered nurse (RN) prior to starting as a NP in PHC, indicating that more education and prior nursing experience may make a NP more efficient and skilled. However, in a US study, Rich (2005) found a negative correlation between years of experience as an RN and NP clinical practice skills; she concluded that $\mathrm{RN}$ experience does not necessarily result in adequate preparation for NP practice. Despite these conflicting perspectives, education and prior nursing experience were identified by MartinMisener et al. (2010) and Rich (2005) as impacting provider time in the sense that the more education and prior RN experience the more efficient the NP may be. Additionally, increased NP education and prior nursing experience have been identified as important to clinic productivity and economic costs in a study conducted in the Netherlands (Dierick-van Daele et al., 2010, 2011), suggesting that NPs with higher levels of education and RN experience may be more efficient and have larger patient panels. Therefore, these factors need to be assessed in relation to NP patient panel size in Ontario PHC settings.

Employment status. Employment status may also influence NP practice. Ortiz et al. (2010) and Donelan, DesRoches, Dittus, and Buerhaus (2013) found that NPs with full-time employment in PHC had increased productivity (i.e., they saw more patients per day), as compared to NPs who were employed on a part-time or casual basis. Buerhaus et al. (2015) reported that NPs in the US worked fewer hours and saw fewer patients than family physicians. Donelan et al. (2013) found that full-time employment was associated with increased productivity and allowed NPs more time to get to know regular patients. Martin-Misener et al. 
(2010), Sloan et al. (2006), and Sangster-Gormley et al. (2012) reported the percentage of NPs in full-time, part-time, and casual employment, but did not relate employment status to NP patient panel size. Martin-Misener et al. (2010) found that $68 \%$ of NPs in PHC were employed full-time in either a CHC or family practice in Nova Scotia. Sloan et al. (2006) in Ontario and SangsterGormley et al. (2012) in British Columbia found that approximately 75\% of NPs were employed full-time, $21 \%$ were part-time, and $2 \%$ were casual.

Level of NP role clarity. It is well recognized that lack of role clarity for NPs inhibits NP practice and role development (Donald et al., 2010; IBM Business Consulting Services, 2003; Koren et al., 2010); however, the literature is mainly from an organizational perspective rather than how NPs view their role clarity. Donald et al. (2010) and IBM Business Consulting Services (2003) found that lack of role clarity was associated with lack of planning, poorly defined goals, and outcomes and potential impact of the role that were not evaluated properly. Lack of role clarity also inhibited NP role integration into interdisciplinary practice teams. IBM Business Consulting Services (2003) found that Ontario NPs with a clearly defined role and/or job description were more likely to be satisfied with their role, and both physicians and NPs were less likely to express concern regarding NP scope of practice and/or liability. Role clarity for both NPs and other members of the interdisciplinary team is important because uncertainty around which patients NPs can care for or how their scope of practice can be used may decrease NP productivity and influence NP patient panel size (Donald et al., 2010; IBM Business Consulting Services, 2003; Koren et al., 2010). Koren et al. (2010) in Ontario and MartinMisener et al. (2010) in Nova Scotia found similar results in that the physician with whom NPs worked most often had a clear understanding of the NP role and supported the NP to practice to their full scope of knowledge and skill; however, some physicians outside of the practice lacked 
this understanding. Many NPs reported frustration with the inability to practice to their full scope due to a lack of interdisciplinary education and of familiarity with the NP role and responsibilities (DiCicco-Bloom \& Cunningham, 2015; Miller, Zantop, Hammer, Faust, \& Grumback, 2004; Sloan et al., 2006; van Soeren et al., 2009; Waszynski et al., 2000; Way et al., 2001).

Having NPs practice to their full scope has the potential to increase their patient panel size. In one study, a physician stated that "understanding the NP scope of practice was difficult at first, taking six months to fully understand the competencies; however, understanding the scope of practice was important to understand the boundaries and how the role could be used" (Humbert et al., 2007, p. 32). Many PHC clinics in Ontario are interdisciplinary; therefore, it is important for NPs and interdisciplinary teams to develop an understanding of NP activities and capabilities in order for the role to be used to its full potential. Most studies have focused on the implications of role clarity in an interdisciplinary team, with few studies looking at how clear NPs were regarding their role.

Overall, further exploration of these NP-related factors in the Ontario PHC context is required to determine their influence on NP patient panel size. The influence of NPs' experience, both as a NP and working in a particular PHC setting, need further exploration in relation to NP patient panel size in Ontario, as available literature was derived from international sources. Similarly, NP education, prior nursing experience, and employment status require further exploration, due to their impact on provider time that may influence NP patient panel size. In addition, the influence of role clarity for NPs and inter-professional team members on NP patient panel size in PHC needs to be further examined in an Ontario context. 


\section{Organizational Factors}

A number of organizational factors that may influence NP patient panel size were noted in the literature. These factors included: time spent in direct care activities; time spent in indirect care activities; clerical and administrative support; structures that influence continuity of care; the interdisciplinary team; NP autonomy; location, size, and model of practice; and NP-physician collaboration. Please see Appendix D for a detailed summary of the literature on organizational factors.

Direct care activities. Overall, research on direct care activities for NPs focused primarily on determining the percentages of time NPs focus on acute illness, chronic illness, health promotion and disease prevention activities, and/or listed the most common types of NP direct patient care activities. The majority of studies reported that NPs spend approximately $75 \%$ of their time in direct patient care activities, with about $45 \%$ on acute illness and $30 \%$ on chronic illness (Deshefy-Longhi et al., 2008; Dierick van Daele et al., 2011; IBM Business Consulting Services, 2003; Koren et al., 2010; Martin-Misener et al., 2010; Mian et al., 2012; Mian \& Koren, 2011; Roots \& MacDonald, 2014; Sloan et al., 2006; van Soeren et al., 2009). NPs' direct patient care activities that were reported across studies included general medical exams, counseling, home visits, chronic disease monitoring and management, wellness and health promotion, and disease prevention (Deshefy-Longhi et al., 2008; Humbert et al., 2007; Koren et al., 2010; Martin-Misener et al., 2010). Donald et al. (2010) and Holcomb (2000) identified that approximately $90 \%$ of the NP roles and responsibilities involved direct patient care activities.

Other studies examined NP direct care activities from the lens of each model of PHC practice. Dahrouge et al. (2014) found that NPs and family physicians in Ontario CHCs spent a similar amount of time in direct clinical care and administrative tasks. However, they did not 
specify what the amount of time was, which is important to understand because of its potential influence on NP patient panel size. Dahrouge et al. (2014) further noted that NPs in Ontario CHCs provide more off-site visits and same-day visits compared to physicians in CHCs. Koren et al. (2010) found that NPs working in FHTs spent more time in direct patient care than did NPs and general practitioner physicians in other practice settings.

Innovative clinical patient visits were important to the NP role and time in direct patient care (Guey-Chi Chen et al., 2014; Koren et al., 2010). These types of visits included group medical visits, telephone, and email for patient correspondence. Email and telephone correspondence had positive impacts among patients and PCPs in that they lowered costs, provided timely appointments, and improved patient satisfaction (Guey-Chi Chen et al., 2014). Koren et al. (2010) found that Ontario NPs estimated engaging in about five telephone patient consultations on average per day. This finding highlights the importance of incorporating telephone patient consultations into the estimation of a NP's time spent in direct patient care activities.

Several studies examined the possibility of using group medical visits for those with chronic illness, and also investigated their impact on provider productivity (Guey-Chi Chen et al., 2014; Mehrotra \& Auerbach, 2014; Watts et al., 2009; Yoshida, Fenick \& Rosenthal, 2014). Group visits have become popular in the US to decrease provider backlog, lower costs, provide timely appointments, improve patient satisfaction, and increase effectiveness of chronic illness management (Guey-Chi Chen et al., 2014; Mehrotra \& Auerbach, 2014; Watts et al., 2009; Yoshida, Fenick \& Rosenthal, 2014). In contrast, Miller et al. (2004) found that group visits for chronic illness did not improve or change provider productivity. In Miller and colleagues' study; 
however, there was no control group to compare provider productivity and participants had complex medical and psychosocial issues.

Indirect care activities. Indirect care included clinical and non-clinical activities such as administration, community development, on-call, research, teaching students, documentation, telephone calls with other care providers, consultation request letter writing, team meetings, leadership, and management activities such as hiring, scheduling or training staff (Chumber, Geller, \& Weier, 2000; Deshefy-Longhi et al., 2008; Dierick van Daele et al., 2011; Koren et al., 2010; Hing et al., 2011; Humbert et al., 2007; IBM Business Consulting Services, 2003; MartinMisener et al., 2010; Mian and Koren, 2011; Mian et al., 2012; Sangster-Gormley et al., 2012; Sloan et al., 2006; Venning et al., 2000). Sangster-Gormley et al.'s (2012) study was one of the few that estimated the number of hours devoted to indirect care activities: NPs spent approximately 10 hours per week in non-clinical activities in British Columbia. Eighty-two percent of NPs in Nova Scotia identified community development as a large part of their role, which included planning and implementing health programs and speaking to communities about health related topics (Martin-Misener et al., 2010). It is important to note that documentation was classified as an indirect patient care activity. No literature was found on electronic medical record (EMR) systems that NPs in PHC clinics use for documentation and how EMRs may impact NP productivity and patient panel size. Questions about EMRs were included in the questionnaire for this study to address this gap in knowledge.

Several studies examined NP indirect care activities through the lens of each model of PHC practice. Koren et al. (2010) and Thibeault (2011) found that NPs who worked in NPLCs spent more time in administrative activities including budgeting, hiring, and health services planning than did NPs who worked in other PHC settings. Holcomb's (2000) was the only study 
that highlighted which contextual factors influenced indirect care noting that the age of the NP, the race of the majority of the patients, the community size, and practice setting predicted how much time a NP needed for community development. In addition, Holcomb found that NPs who worked in FHTs were less involved in research activities than were NPs who worked in other PHC settings. These findings highlight the importance of practice-specific factors that require further consideration when estimating the amount of NP time in indirect care activities that may influence NP patient panel size.

Two other studies focused on unique indirect care activities. Haber et al. (2009) presented an example of NPs who joined forces with a dental clinic to foster collaboration and referrals to PHC. In this study, NPs networked with dental school faculty to develop relationships to foster this collaboration. In exchange, NPs taught second year dental students to take an accurate blood pressure reading. This was one unique example of an indirect patient care activity in which NPs participated with other health care professionals to create better models of care for patients. Reay, Patterson, Halma, and Steed (2006) used qualitative methods in a rural FHT and found that part of the NP role was to work closely with other clinic staff to develop programs for particular chronic diseases aimed at improving patient outcomes. Through this collaboration, the NP developed strong community partnerships to address many community health issues; engagement in this activity increased the value of NP care and the community's satisfaction with the NP role. These studies highlighted some of the indirect care activities in which NPs engage, as well as the complexities inherent in these activities.

Personnel support. Structures such as staff support (e.g., reception, secretarial, administrative, and housekeeping staff) increase clinic productivity and patient panel size (Dahrouge et al., 2014; DiCenso et al., 2010; Duck et al., 2001; Hayes, 2007; Liu, Finkelstein, \& 
Poghosyan, 2014; Muldoon et al., 2012; Rayner, 2014; Sloan et al., 2006; VHA, 2009, 2014).

Both Poghosyan et al. (2015) in the US and van Soeren et al. (2009) in Ontario reported that NPs in PHC were frustrated with the lack of funding for clerical support. In a qualitative study, Abood (2005) found that "NPs often have to do everything including being the NP, RN, scheduler, setting up rooms, etc.” (p. 121). The VHA (2009) recommended 2.17 full-time equivalent (FTE) support staff per one FTE PCP in order to support a patient panel of approximately 1,200 patients who require comprehensive primary care. In 2014, the VHA increased this recommendation to a support staff ratio of at least three FTE support staff per one FTE PCP. The VHA defined support staff generally as an RN care manager, a clinical associate such as a registered practical nurse (RPN), or an administrative associate (e.g., receptionist). The VHA $(2009,2014)$ reports were the only literature sources to provide specific recommendations regarding numbers and types of staff support. Because the VHA is a US source the relevance of this evidence to the Canadian context is unclear.

Practice model, size, and location. Contextual factors related to practice model, size, and location require further consideration in relation to NP patient panel size. Two studies found that the number of patients seen per day by a NP depended on the practice model. IBM Business Consulting Services (2003) in Ontario and Oritz et al. (2010) in the US reported that NPs in FHTs tended to see more patients per day than did those in CHCs (approximately 14 vs. 11 patients per day, respectively). This difference was attributed to the fact that CHCs had more same-day patient visits, new patients, and patients who presented with complex psychosocial issues (IBM Business Consulting Services, 2003).

Several studies found that the size of the practice played an important role in terms of the number of patients it could accommodate. Larger practices were often able to have a greater 
number of exam rooms per PCP and more staff overall to support an increased patient panel size (Dahrouge et al., 2014; DiCenso et al., 2010; Duck et al., 2001; Hayes, 2007; Liu et al., 2014; Muldoon et al., 2012; Rayner, 2014; Sloan et al., 2006; VHA 2009, 2014). The VHA (2009, 2014) recommended three exam or consult rooms per PCP. The VHA also noted that teaching students and other learners requires additional clinic rooms. Dierick-van Daele et al. (2011) and Oritz et al. (2010) found that a larger practice was associated with a larger number of NPs and therefore, more NPs to see patients, potentially increasing NP patient panel size.

Lastly, practice location emerged as an important contextual factor. Several studies in the US and Canada found that urban practices tend to have more NPs than do rural practices. In rural locations, NPs worked longer hours, with less support, saw more patients, and often had to travel between PHC sites (Buerhaus et al., 2015; Koren et al., 2010; Martin, 2000; Huang, Yano, Lee, Chang, \& Rubenstein, 2004). In addition, Koren et al. (2010) and Thibeault (2011) found that NPs working in Ontario NPLCs often worked between multiple sites. Humbert et al. (2007) highlighted that NP travel time between PHC settings in Ontario must be taken into consideration to understand its influence on NP patient panel size.

NP autonomy. The benefits of NPs having an increased level of autonomy in PHC are well documented. Several studies in Canada and the US have found that NPs who had greater clinical decision-making authority in their work setting, and were able to share decisions and practice to their full scope, provided high quality patient care, and had increased clinic productivity and job satisfaction (Abood, 2005; Chumber et al., 2000; Duck et al., 2001; GueyChi Chen et al., 2014; IBM Business Consulting Services, 2003; Koren et al., 2010; Poghosyan, Nannini, \& Clarke, 2013; Tomblin Murphy, 2004; van Soeren et al., 2009). In addition, Roots and MacDonald (2014), Carryer and Yarwood (2015), and IBM Business Consulting Services 
(2003) found that optimizing NP autonomy in PHC improved patient safety, inter-professional relationships, and resulted in better patient health outcomes. Waszynski et al. (2000) and Way et al. (2011) reported that NPs were often not utilized to their full capacity due to a lack of understanding of the NP competencies. Venning et al. (2000) found that NPs reported spending a mean of 1.33 minutes per patient waiting for a prescription signature from the family physician, which resulted in wasted time and fragmented care.

Johnson (2005) found that NP autonomy often depended on the type of care environment in which a NP works: NPs in specialty practices were viewed as an added value, whereas NPs in PHC practices were often viewed as a substitute for a physician. Dierick van Daele et al. (2009, 2011) and Liu and D'Aunno (2012) found that when a NP in PHC assumed a substitution role for a physician, they were able to replace $70-80 \%$ of physician activities. Furthermore, when NPs worked in a complimentary role, as an addition to the team to augment particular care needs, they spent more time on non-substitutive activities, such as health promotion and disease prevention, and they were able to improve quality of care and optimize costs (Kralewski, Dowd, Curoe, Savage, \& Tong, 2015; Martin-Misener et al., 2015).

Interest in NP patient panel size is relatively recent, and therefore research on the topic is limited. However, several studies suggested that having NPs carry their own patient panel led to many benefits in terms of workload and patient care. For example, Martin (2000) found that NPs working in rural settings were more likely to be the principle PCP for patients, and therefore saw more patients compared to NPs that were not the principle PCP for their patients. Other studies recognized that NPs who were the principle PCP for a group of patients had greater clinical decision-making authority and increased productivity, which translated into increased patient accessibility to care and overall satisfaction (Abood, 2005; Chumber et al., 2000; Rayner 2014; 
VHA, 2009, 2014). Muldoon et al. (2013) found that NPs were the principle PCPs for $22 \%$ of patients in CHCs. Koren et al. (2010) found that PHC NPs provided care for $80 \%$ of their clients autonomously or with minimal physician consultation. These results indicate that NPs may have different patient panel sizes depending on the PHC practice model, and that there are benefits to carrying their own patient panel.

Interdisciplinary team and NP-physician collaboration. Interdisciplinary team and NP-physician collaboration are both highly interconnected, as well as connected to the concept of role clarity as previously noted. Working within multidisciplinary teams was well-documented in the literature as a way to increase patient panel size (Chumbler, 2000; Duck et al., 2001; Muldoon et al., 2013; Poghosyan et al., 2012; Rayner, 2014; Roots \& MacDonald, 2014; Sangster-Gormley et al., 2012; Sangster-Gormley et al., 2015; VHA, 2009, 2014). In contrast, Muldoon et al. (2013) found that the addition of inter-professional staff in Ontario CHCs, such as a social worker to the team, did not increase patient panel size. However, this finding was specific to the CHC model where additional resources are provided, such as a co-location with food banks (Muldoon et al., 2013).

Various patient panel-sharing methods between NPs and physicians have been identified, including provider capacity pooling and partial pooling methods. Liu, Ozen, and Balasubramanian (2013) discussed the usefulness of a partial pooling model, wherein the providers formed a team and shared a subgroup of patients, but retained a certain number of patients who were assigned to only one PCP. This partial pooling model allowed for both continuity of patient care and provider independence. Physicians and NPs who engaged in a shared-panel model, worked as a team, and shared equal role status within the team had overall 
increased communication, productivity, and cost-efficiency (Buerhaus et al., 2015; IBM Business Consulting Services, 2003; Lui and D’Aunno, 2012; Miller et al., 2004).

Grover and Niecko-Najjum (2013) highlighted the fact that some physicians continue to be reluctant to allow NP autonomy, to work as part of a team, and to share patient responsibility, office space, and examination rooms with NPs. These physician behaviours perpetuate the barriers to team-based PHC models. In settings where this reluctance and siloed practice occurs, NPs typically view their relationship with physicians as supervisory rather than collaborative, NPs in such settings often report dissatisfaction with intra- and inter-practice partnerships, which negatively impacts NP productivity (IBM Business Consulting Services, 2003; Koren et al., 2010; Poghosyan et al., 2012; Poghosyan \& Aiken, 2015; Roots \& MacDonald, 2014; SangsterGormley et al., 2012). On the other hand, shared decision making, the implementation of a shared patient care plan, and respect for each other's skills and knowledge when making shared decisions were factors associated with greater satisfaction with NP-physician collaborations (Chumbler, 2000; DiCicco-Bloom \& Cunningham, 2015; IBM Business Consulting Services, 2003). Phillips, Bazemore, and Peterson (2014) stressed that inter-professional practice has great potential to improve continuity of care for patients due to NPs having more independence with their patients and the ability to consult their physician partner when needed. Despite this literature, inter-professional team dynamics have not been explored specifically in relation to NP patient panel size in an Ontario PHC context; therefore, further exploration is required.

Other studies focused on the impact on physician patient panel size when a physician delegated to and supervised NPs. Altschuler, Margolius, Bodenheimer, and Grumbach (2012), Dierick-van Daele et al. (2011), Duck et al. (2001), and Muldoon et al. (2012) highlighted how inter-professional teams allowed physician patient panel size and productivity to be increased 
either through substitution, delegation, and/or supplementation using a NP. However, one study by Lui and D'Aunno (2012) revealed the supervisory role of general practitioners decreased their productivity and patient panel size due to the extra time spent in managing NPs and accepting their referrals. These studies indicate the focus on physician patient panel size in the literature and bring attention to the lack of studies regarding NP patient panel size.

As discussed above, there are many organizational barriers that require further exploration from the Ontario perspective in relation to NP patient panel size. The majority of the literature investigating direct and indirect care activities is based on the percentage of NP time or types of activities in which NPs engage. However, to date, no study has described the relationship between these activities and NP patient panel size to further understand what direct and indirect activities NPs engage in that may impact how many patients they can care for. Therefore, this relationship needs to be investigated. Innovative direct clinical patient visits, such as group visits, tele-health, etc., also require further exploration in relation to NP patient panel size due to their novel use in health care. In addition, the amount and types of personnel support to which NPs have access in various PHC settings requires further exploration in Canadian settings, as much of the literature is international and little is known around this factor's influence on NP patient panel size. Organizational factors that potentially influence NP patient panel size, such as multiple versus single site PHC settings; NP autonomy; interdisciplinary team; and physician collaborative relationship need to be investigated. Much of the literature described above has noted the importance of these organizational factors to NP practice and workload; however, the literature has not examined these factors' influence on NP patient panel size. 


\section{Summary of Literature Review}

The literature reviewed identified many patient, NP, and organizational factors that may influence NP workload and patient panel size; however, few studies examined these factors specifically in relation to NP patient panel size, and few were conducted in an Ontario PHC context. Patient factors consistently identified as impacting NP consultation time and requiring more resources included older age, female gender, and lower socioeconomic status. However, few studies assessed the relationship between these patient factors and NP patient panel size. Furthermore, many studies found that a master's education for NPs, full-time employment, and role clarity for the NP role all increased a NP's ability to handle an increased workload. Although the literature has identified these factors as important to NP practice and workload, few studies have explored the relationship between these factors to NP patient panel size. Organizational factors such as the amount of time NPs spend in direct and indirect care activities, NP autonomy, practice-specific factors across PHC settings, personnel support, and the NP role within an interdisciplinary healthcare team were all identified as impacting NP workload and productivity; however, these organizational factors were also not assessed in relation to NP patient panel size.

Other factors that appear important to consider, yet have little research to demonstrate their impact on NP patient panel size include: same-day patient visits; new patients to a practice and/or a NP; NPs having their own patient panel; innovative health visits; and the prior nursing experience of NPs. Conflicting results were found around the use of group patient visits for chronic illness patients, which were seen as a way to potentially improve provider productivity that may influence panel size, as well as the patient age groups a NP sees within different PHC practice models. Gaps in the literature around emerging factors such as EMR systems and 
transgender patients were identified and were included in the present study to determine their influence on NP patient panel size.

In terms of research design, most of the studies included in the review used crosssectional surveys that focused on self-reporting measures around aspects of the NP role (e.g., percentage of time NPs spend in direct and indirect care activities). Few studies assessed the relationship between these aspects and NP patient panel size. Also, the existing literature has primarily investigated factors that influence physician, rather than NP, patient panel size. As previously described, factors influencing physician patient panel size are likely similar to factors affecting NP patient panel size due to similar work environments, overlap in roles, and types of patients being cared for. However, without evidence that these factors are also applicable to NP patient panel size, this remains an untested assumption. Another consideration is that $70 \%(n=$ 47) of the 67 articles reviewed were not conducted in Ontario. For example, the VHA (2009, 2014) has published articles providing strong recommendations around numbers and types of support personnel required within a PHC clinic in order to support an adequate patient panel for PCPs. As these reports were from the US, the findings may not be applicable in a Canadian context where the healthcare system differs considerably. Furthermore, even within Canada, the NP scope of practice, role, and contextual factors such as clinic location (e.g., the proportion of rural clinics) may vary from province to province, and also may differ from international settings. The 20 articles (30\%) reviewed that represented an Ontario sample did not specifically relate patient, NP, or organizational factors to NP patient panel size. The analysis of the literature demonstrates a need for further examination of the identified factors that influence NP practice and workload in Ontario in order to inform efforts to optimize NP patient panel size. 


\section{Conceptual Model and Definitions}

In this section, the overarching conceptual model is presented, the components of the model guiding this study are further explained, and the corresponding concepts are defined.

Conceptual model. The conceptual model that guided the present study is shown in Figure 1. Martin-Misener et al. (2015) developed a model for determining NP patient panel size through a rigorous review of the literature. This model shows the relevant factors believed to be associated with the NP role and activities to consider when determining NP patient panel size in PHC. The model includes three components that impact NP roles and activities located in the center of the model. These components include 1) influencing factors, 2) outcomes, and 3) patient panel size. Each component is involved in a reciprocal relationship with the other three components of the model. The model highlights the importance of accounting population needs, patient, provider, organizational, and system factors that affect the NP role and scope of practice. These factors may in turn affect the optimal patient panel size for a PHC setting. It is important to note that the NP roles and activities also impact patient, provider, and healthcare system outcomes. The link between patient panel size and outcomes is also critical; however, at this time the relationships with outcomes remain unknown and panel size should be adjusted accordingly once the relationships between patient panel size and outcomes are clarified with further research. NP roles and activities are situated in the middle of the model, as the NP role is the focus of both the present study and the larger research study. Bidirectional arrows, interconnectedness among the model's components, and the circular shape of the model indicate the dynamic interaction between the model elements (Martin-Misener et al., 2015).

The present study focuses on select components of the model. The three model components that were assessed include the influencing factors, NP roles and activities, and 
patient panel size (as indicated by the grey boxes in Figure 1). Influencing factors included patient, NP, and organizational factors. These factors were identified based on existing literature. Since the presence, direction, and magnitude of the association between these factors and NP patient panel size were not clearly and consistently described in the literature, this study explored these associations.

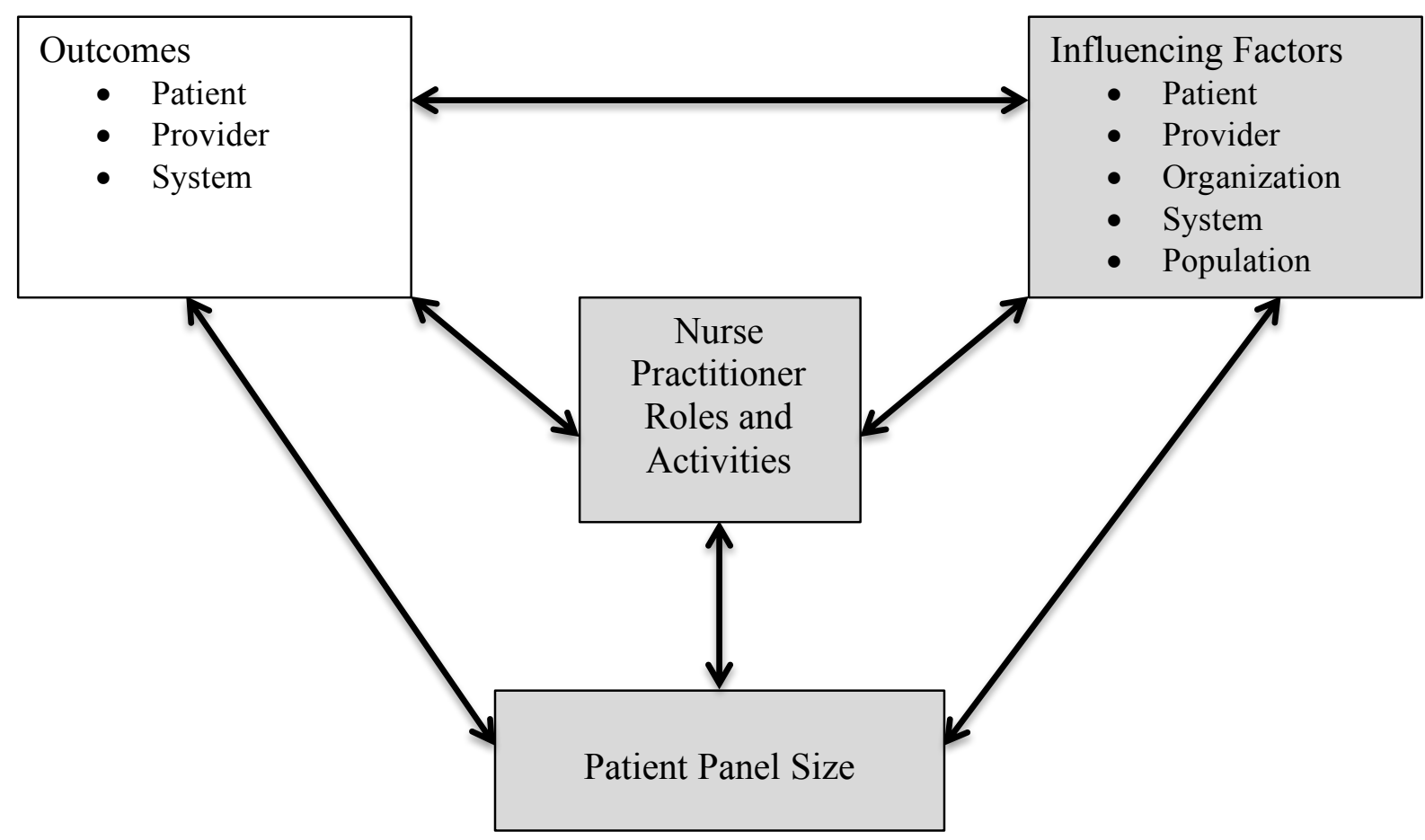

Figure 1. Adapted from conceptual model for NP patient panel size in PHC taken from MartinMisener et al.'s (2015) Benchmarking for nurse practitioner caseload and comparative analysis of nurse practitioner pay scales: Update of a scoping review. The grey boxes indicate the areas of focus for the present study. Adapted with permission from the primary author.

\section{Definitions of components in the model.}

Primary health care (PHC). PHC was defined as first contact for care related to all issues encompassing health, including income, housing, education, and environment, that often takes place in a community setting (Health Canada, 2012). Primary care is the element within PHC that focuses on health care services, including health promotion, disease prevention, and the 
diagnosis and treatment of illness and injury (Health Canada, 2012). A patient within PHC is a person receiving and/or registered to receive any service and/or treatment from a PCP within a community setting with a focus on health promotion, disease prevention, health empowerment, and the diagnosis and treatment of illness and injury (CNA, 2015). Models of PHC clinics vary and may or may not consist of a priority and/or specialty patient population such as a community mental health clinic where primary care is provided.

Patient factors. Patient factors examined within this study included demographic and health-related characteristics of the individual patient that may affect the contact time with a NP. They included: age, gender, socioeconomic status, health status, and whether a patient is new to a practice, provider, and/or is a same-day visit.

Age. Patient age referred to the number of years that a person has lived (MerriamWebster's, n.d.).

Gender. Gender was the person's self-identification as male, female, or transgendered. It does not exclusively refer to biological sex, but rather the socially-constructed roles, behaviours, activities, and attributes that shape a given patient (Merriam-Webster's, n.d.).

Socioeconomic status. Socioeconomic status was the social standing or class of an individual. It is often measured as a combination of education, income, and occupation (Merriam-Webster's, n.d.). Income was used as the measure of socioeconomic status in this study.

Health status. Health status is a holistic and subjective concept that reflects the person's overall state and is determined by more than the presence or absence of any disease. It is often self-assessed and involves measures of functioning, physical illness, mental wellness, and quality of life (Statistics Canada, 2013). However, the health status of a patient in the present study was 
operationalized with having an acute, chronic, or multi-morbid condition. An acute condition was defined as any illness that has sudden onset and lasts a relatively short period of time (e.g., infection or trauma) where the patient returns to their original healthy state within three months (Medical Dictionary, n.d.). A chronic condition was defined as any illness persisting for longer than three months that cannot generally be cured but rather requires proper management (e.g., diabetes; Wallace et al., 2015). Multi-morbidity was defined as two or more chronic conditions in an individual (Wallace et al., 2015).

New patient visits. New patients are patients who have not received any professional services (e.g., face-to-face consultation, assessment, and/or management) from either a specific PHC practice and/or from a specific NP, in a particular clinical setting within the previous two years (Hing et al., 2011). New patient visits were distinct from patients who had not been seen by the NP, but were known to the clinic. New patient visits may also be same-day visits.

Same-day patient visits. Same-day patient visits included those made by patients who call the PHC clinic for an appointment on the same day or walk into a clinic seeking a service (e.g., assessment by a PCP, prescription renewal) without having arranged for an appointment (Dahrouge et al., 2014). These patients may or may not have been regularly seen by a PCP at that particular site.

NP factors. The definition of a NP and their scope of practice were provided in Chapter 1. NP factors included demographic characteristics of the NP and the experience of an individual NP that influence how the NP practices. These factors were the years of experience the NP has practiced in total and in their current practice setting, NP education, prior nursing experience, employment status, and lack of role clarity for the NP. 
Years of experience. Years of experience working as a NP referred to the amount of time in years a NP has been working in the NP role in any healthcare setting (Dierick-van Daele et al., 2009). Years of experience a NP had in a particular PHC setting was the number of years a NP had worked at a particular PHC site (VHA, 2009).

NP education. NP education was the highest degree (e.g., master's degree) and credentials (e.g., certification) attained by a NP (Canadian Association of Schools of Nursing, 2012).

Prior nursing experience. Prior nursing experience was defined as a NPs' previous type of nursing experience prior to attaining NP certification (Rich, 2005).

Employment status. Employment status was operationalized by the classification of a NP's work as full-time, part-time, or casual in a particular PHC setting (Buerhaus et al., 2015; Donelan et al., 2013). Full-time was greater than or equal to 35 hours per week worked, part time was 20 to 34 hours per week worked, and causal was less than 20 hours per week worked.

Level of NP role clarity. NP role clarity was defined as a NPs' understanding of their overall job description, scope of practice, responsibilities, and key accountabilities within an interdisciplinary healthcare team (Donald et al., 2010). This concept also overlapped with how well other team members understand the NP role, which was considered an organizational factor in the present study. Both were examined in the present study.

Organizational factors. Organizational factors were characteristics within PHC settings, including the structure, activities, communication, and culture in a PHC practice that may influence NP patient panel size. Organizational factors included NP engagement in activities that involved both direct and indirect care activities; personnel support; practice model, size, and location; NP autonomy; the interdisciplinary team; and NP-physician collaboration. 
Direct care activities. These were conceptually defined as any activity in which the NP engages directly with the patient in-person or via technology (e.g., email, telephone) to influence a patient's health. Example activities include: counseling, assessment, patient education, home visits, and chronic disease monitoring and management (Deshefy-Longhi et al., 2008; Humbert et al., 2007; Koren et al., 2010).

Indirect care activities. These included any clinical or non-clinical activity in which a NP engages that does not involve direct contact with the patient; however, these activities may still influence a patient's plan of care and/or health outcomes. Example activities include: community development, referral letter writing, documentation, team meetings about patient care, and telephone calls with other care providers (Koren et al., 2010; Martin-Misener et al., 2010; Sangster-Gormley et al., 2012).

Personnel support. Personnel support refers to staff (e.g., clerical and housekeeping staff) who help NPs schedule appointments, fax letters, and clean exam rooms in between patients. These personnel enable NPs to better focus on patient care responsibilities (Muldoon et al., 2012; Rayner, 2014). Personnel support also referred to other healthcare professionals with whom the NP works in order to provide holistic patient care (e.g., social workers) (VHA 2009; 2014).

Practice model. Practice model was the type of PHC setting in which a NP works (IBM Business Consulting Services, 2003). For the purposes of this study, practice models included: FHTs, NPLCs, AHACs, CHCs, family physician's office or walk-in clinics.

Practice size. Practice size referred to the physical structure of the practice in terms of physical space (e.g., number of exam rooms and offices), and the number of patients and staff a PHC clinic could accommodate (Dahrouge et al., 2014; VHA, 2009). 
Practice location. Practice location distinguished between remote, rural, small town or urban communities in which a PHC clinic was situated, and in characterizing the geographic location of the population it served. Remote was defined as a geographical area without year round road access or which relied on a third party (e.g., train, airplane, or ferry) for transportation to a larger centre (MOHLTC, 2011). Rural was defined as a community in Ontario with a population of less than 30,000 that was greater than 30 minutes away from a community with a population of more than 30,000 (MOHLTC, 2011). A small town was defined as having a population of generally 30,000 to 50,000 (Statistics Canada, 2015). Lastly, an urban community generally had an urban core of 50,000 and a regional population of greater than 100,000 (Statistics Canada, 2015).

NP autonomy. NP autonomy was defined as the degree to which a NP had the authority to make independent decisions and act in accordance with his or her professional knowledge to impact a patient's health and/or plan of care (Abood, 2005). A high degree of autonomy may lead NPs to have their own patient panel (Abood, 2005; Duck et al., 2001; Guey-Chi Chen et al., 2014; IBM Business Consulting Services, 2003; Poghosyan, Nannini, \& Clarke, 2013)

Interdisciplinary team. The interdisciplinary team included the group of healthcare professionals from diverse fields with whom a NP worked in a coordinated fashion to achieve common patient goals (IBM Business Consulting Services, 2003).

NP-physician collaboration. NP-physician collaboration describes the process and relationship through which a NP collaborates with one or more physicians to deliver healthcare services (IBM Business Consulting Services, 2003).

Inter-professional collaborative practice. Bridges, Davidson, Odegard, Maki, and Tomkowiak (2011) defined inter-professional collaborative practice as a sharing process, which 
includes communication and decision-making that enables a synergistic influence of grouped knowledge and skills of care providers that improve patient outcomes and the quality of patient care. NPs engage in inter-professional collaborative practice with both the interdisciplinary team and the physician(s) with whom they work regularly.

\section{Research Questions}

Primary research question. What are the patient, NP, and organizational factors that are associated with NP patient panel size in PHC settings in Ontario?

Secondary research questions. Secondary research questions included:

1. What is the relationship between each of the patient, NP, and organizational factors and NP patient panel size?

2. Of the patient factors, which have the strongest association with NP patient panel size?

3. Of the NP factors, which have the strongest association with NP patient panel size?

4. Of the organizational factors, which have the strongest association with NP patient panel size?

\section{Hypotheses}

Based on the literature and the conceptual model, some relationships could be hypothesized in advance. Patient panel size was hypothesized to be lower for NPs who care for a high proportion of patients who are older, female, economically disadvantaged, and/or have multiple chronic diseases; these patients require longer consultation times and more organization of resources. Novice NPs were hypothesized to be more likely to be assigned smaller patient panel sizes due to inexperience and their need for slightly longer times to complete assessments. It was also hypothesized that NPs who work in large, urban practices with more support staff and 
increased autonomy may have larger patient panel sizes. These hypotheses were tested in the present study. 


\section{Chapter 3: Methods}

In this chapter, the study design is explained, followed by a description of the target population and sample. Procedures used for data collection, the protection of human subjects, and the data analysis plan are explained. Information about the instrument that was used in the study is also presented.

\section{Design}

This quantitative study employed a cross-sectional survey design. This design was appropriate for use in exploring and describing a phenomenon of interest in real-life situations, and is considered to be particularly useful for the generation of new knowledge on an understudied topic (Grove, Burns, \& Gray, 2013). A survey design also allowed for data to be collected over a short period of time and was relatively inexpensive (Grove et al., 2013). Factors influencing NP patient panel size in PHC from an Ontario-wide NP perspective have not been previously investigated.

A mailed questionnaire was used to gather a broad range of information about patient, NP, and organizational factors that may impact NP patient panel size in PHC from the Ontario NP perspective. Self-administered questionnaires are useful for collecting data on the knowledge, opinions, attitudes, and values of a sample of individuals (Polit \& Beck, 2004).

\section{Sample}

All NPs working in PHC settings in Ontario were invited to participate in this study. The inclusion criteria for participation in this study were: 1) NPs (PHC, adult, and paediatric) registered with the $\mathrm{CNO}, 2$ ) employment in a PHC setting in Ontario (e.g., CHCs, NPLCs, FHTs, AHACs, and family physician clinics), and 3) had provided consent through the CNO to be contacted for nursing research purposes and/or provided their mailing addresses to the 
researchers via email. NPs that indicated on their CNO registration that their first language was French were included; however, the questionnaire was only distributed in English. Exclusion criteria included NPs working in outpatient settings within acute care facilities, long-term care, rehabilitation, and other areas that are not clearly identified as PHC settings.

\section{Sample Size, Power, and Effect Size}

Prior to completing the data analysis plan, sample size, power, and effect size were considered. A sample size calculation using a power analysis could not be completed accurately prior to this study. This was due to uncertainty around how many members of the target population had consented through the $\mathrm{CNO}$ to be contacted for research purposes, as well as the novelty of NP patient panel size and there being limited knowledge about the likely effect size prior to statistical analysis. However, CNO`s membership statistics $(2014 ; 2015)$ were used to gain an understanding of the accessible population. Furthermore, Cohen (1988) recommends a power of 0.80 and an alpha $(\alpha)$ or significance criterion of 0.05 to reduce the risk of Type II error. Tabachnick and Fidell (2007) offer a simple guideline for regression analysis when effect size is not known where $\mathrm{N} \geq 50+8 k$ where $k$ is the number of predictors/independent variables (IVs). Applying this guideline, there were approximately seven patient variables, five NP variables, and 10 organizational barriers for the three regression models requiring minimum sample sizes of 106, 90, and 130 respectively. Cohen (1988) also uses the general rule of 10 cases per IV when effect size cannot be calculated. These guidelines offered a frame of reference for required sample size of approximately 220 to 326 cases to obtain an adequately powered study. 


\section{Recruitment Strategies}

A two-pronged recruitment strategy was used. The first strategy involved obtaining a convenience sample through the CNO after Research Ethics Board (REB) approval had been obtained for this study. The CNO registration process asks NPs for consent to be contacted for research purposes. Those who consent are placed on a list for the CNO to release to researchers. This list of all the NPs who consented to be contacted and who were working in PHC settings in Ontario was obtained from the CNO following the submission of a data request form. The NPs on the list were invited to participate by mailing them a package that contained an information letter and the study questionnaire. According to the CNO's 2014 membership statistics, there were 1,167 NPs working in PHC; this statistic was not updated in their 2015 membership statistics (CNO, 2014, 2015). At the time of the list request (July, 2015), the CNO sent 558 names and mailing addresses of NPs who met the study eligibility criteria.

Convenience sampling has both strengths and limitations. Convenience samples are useful to obtain information in previously unexamined areas, are economical and accessible, and require less time to attain than random sampling methods (Grove et al., 2013). Because of these considerations, convenience sampling was used for the present study's novel research topic. On the other hand, this sampling method has weaknesses due to its limited opportunities for researchers to control for biases, such as selection bias. Due to voluntary participation in convenience samples, this may result in the oversampling of people who have strong opinions and under-sampling of people who do not. This sampling bias also has the potential to yield an unrepresentative sample, which impacts the generalizability of findings (Grove et al., 2013). Inclusion and exclusion parameters were implemented to combat potential sampling bias. As well, the characteristics of the present study's sample were compared to those reported by CNO 
to determine the extent to which the study sample was representative of the target population (See Chapter 5). These limitations were also taken into consideration when interpreting the findings.

The second recruitment strategy involved a networking approach that was employed to further increase both the sampling pool and response rates. At two conferences that have a high number of NP attendees, Primary Care Today (PCT) and the Nurse Practitioner-Led Clinic Leadership Conference, a flyer (Appendix E) was displayed at an information booth in an effort to recruit NPs who were interested in hearing more about the present study. A sign-up sheet was available for interested NPs to provide their names and email addresses. Fifty-two NPs provided email addresses during these conferences. In addition, six NPs who heard about the study from colleagues contacted the research team requesting that the questionnaire be mailed to them. These additional 58 NP names were compared to the CNO list; 28 of them were not on the CNO list. These 28 NPs were sent, via email (Appendix F) information about the study. Two reminder emails were sent at two-week intervals for those that did not reply. Fifteen of the 28 NPs responded with their mailing addresses. This brought the total accessible sample to 573 .

\section{Ethical Considerations}

The researcher obtained approval from the Research Ethics Board at Ryerson University (Appendix G). A code was assigned to each potential participant. All study participants were provided with an information letter that invited them to participate, which detailed the purpose of the study, the voluntary nature of participation, strategies used by the researchers to provide confidentiality, and the researchers' contact information (Appendix H). Return of the completed questionnaire was indicative of consent to participate (i.e., implied consent). Participants were informed that data collection and responses were strictly confidential and only the researchers 
would have access to questionnaire responses. Participants were not asked to identify the specific clinic in which they work or their name. Numeric codes facilitated confidentiality during data analysis (Grove et al., 2013), and only aggregate data were reported.

No participant harm was anticipated as a result of taking part in this study. A personal incentive of a five-dollar Tim Horton's gift card was attached to each initial questionnaire package in appreciation of the time participants took to complete the questionnaire. Research has also shown that response rates for postal questionnaires increase by more than two-fold when a monetary incentive is included that is not conditional on response (Dillman, 2009; Edwards et al., 2002).

Returned completed questionnaires were kept in a locked file cabinet in the office at the researcher's home during data analysis. Both the $\mathrm{CNO}$ list of names and the additional list of collected names with assigned numeric codes were kept in a separate locked cabinet in the researcher's home. All coded data were stored in encrypted password-protected files on password-protected computers, as well as encrypted and password protected USB keys. Participants were informed they had up to one month after their questionnaire submission to withdraw their consent and request their responses to be deleted from the database. No participants withdrew from the study.

As per the recommended Ryerson REB policy, data and relevant study materials will be kept at Ryerson in a locked cabinet in a secure area for a minimum of five years following the study. Anonymized data may be accessed for further research about NP practice and/or patient panel size by graduate students until March 31, 2021. It will not be possible to link these data to an individual participant or their organization, as all identifying information has been removed. 
After March 31, 2021 all electronic data will be deleted and all paper data will be cross-shredded to ensure complete destruction.

\section{Variables and Measures}

Variables. The three categories of study variables included patient, NP, and organizational factors. Study variables have been previously described in Chapter 2 .

Instrument. The questionnaire was adapted from three publicly-available instruments from the Canadian Institute of Health Information (CIHI)(2013): "Measuring Patient Experiences in Primary Healthcare”, "Attributes of Primary Healthcare Providers”, and "Measuring Organizational Attributes of Primary Healthcare". These three questionnaires can be retrieved directly from the CIHI website (https:/www.cihi.ca/en/types-of-care/primary-healthcare). A panel of experts developed the patient, provider, and organizational questionnaires based on available literature and publicly available questions. During the process, two conceptual frameworks were consulted, those of Hogg, Rowan, Russell, Geneau, and Muldoon (2008) and Watson, Broemeling, and Wong (2009), to guide aspects of PHC that would be included in the questionnaires (CIHI, 2013). Development of the questionnaires was further informed by results of cognitive interview testing in the field and input from stakeholder groups in both English and French. The CIHI (2013) did not report data on the reliability and validity of the instruments.

For the present study, relevant questions from these three CIHI instruments were selected to obtain data on the variables of interest. The CIHI (2013) instruments were not used in their entirety due to their very broad scope, which is intended to cover multiple topics within PHC. The selected questions were closed-ended and were adapted to a NP-focus. For example, 'physician' was replaced with 'NP' where relevant. Topics addressed in the resulting questionnaire included: demographic characteristics of both NPs and the patients they care for; 
how NPs spent their time; clinical and non-clinical activities performed; NPs' perceptions of autonomy; and organizational structures including personnel support, technology support, coordination of care and collaboration, and team functioning. Selected questions operationalized the factors identified in the literature as likely to influence NP patient panel size. In addition, questions were created and added based on discussions and feedback with experts in PHC, including NPs working in PHC settings, PCPs, the larger research study team, and the Canadian Centre for Advanced Practice Nursing Research (CCAPNAR) team. These discussions resulted in the addition of questions designed to assess factors that did not appear in the literature. For example, experts recognized that additional time was likely required for patients experiencing personal crises or identity confusion, such as those who are questioning their gender. As such, a question on the topic of gender identity was included.

The final questionnaire contained 54 closed-ended questions that were estimated to take 45 minutes to complete. The response options included eight Likert scale questions, three rank order questions, and various response options for the remaining 43 items, including lists, categories, time in minutes/years, and estimated percentage. Each question was designed to measure an aspect of a particular study variable (See Appendix I for a summary of the questions used for each variable). Some variables (e.g., NP satisfaction with the interdisciplinary team) were measured using several questions; a total score based on the sum of the relevant items was computed to quantify the NPs' overall level on such variables.

\section{Pilot Testing}

A pilot test was conducted to obtain feedback regarding the readability, content appropriateness, and format of the cover letter and questionnaire. Pilot testing involved four NPs (with different amounts and types of PHC experience, including a Francophone NP) from four 
different PHC settings. These NPs were mailed a package that included the following items: 1) a cover letter outlining the purpose of the pilot test, their role as a pilot tester, and the process for their feedback (Appendix J); 2) a consent form for participation in the pilot; 3) an evaluation form (Appendix K); 4) the information form that would be sent to all participants; 5) the questionnaire; and 6) a ten-dollar Tim Horton's gift card as a token of appreciation for their time and effort. Two reminder emails were sent at one-week intervals to remind the NPs to mail back the pilot questionnaire and the evaluation form. All four pilot testers returned the survey, and all four indicated that the questionnaire was comprehensive, the content was appropriate, and the format of the questionnaire was easy to follow. Based on their feedback, minor changes were made to 14 questions to improve clarity prior to mailing the questionnaire to all study participants. The four NPs who participated in the pilot testing and their responses on the pilot questionnaire were excluded from the final study sample.

\section{Data Collection}

A package, containing the cover letter, information form, the questionnaire, a return stamped envelope, and a five-dollar Tim Horton's gift card was mailed to all eligible participants in early November, 2015. Participants completed the questionnaire at a time and place of their choosing, and at their own pace. They were asked to return the completed questionnaire within two weeks, using the provided researcher-addressed return envelope with pre-paid postage. The use of a return envelope with pre-paid postage ensured that completing the questionnaire will result in no cost to the participants and increases response rates (Edwards et al., 2002). In order to increase response rates, Dillman's (2009) method was used, whereby participants were informed that if they did not return the questionnaire within two weeks, up to two reminder questionnaires would be automatically sent at two-week intervals. The reminder packages 
consisted of a cover letter, information form, and the questionnaire, and a researcher-addressed envelope, but gift cards were only sent in the initial mailing. Numeric codes were used by the researcher to track responses and to identify participants who required a reminder questionnaire. Questionnaires were accepted for a period of 11 weeks after the initial mailing date (from November 5, 2015 to January 25, 2016) to avoid holiday interruptions.

\section{Data Analysis}

All data were coded and entered into a database created in the Statistical Package for the Social Sciences (SPSS), version 23. The data were crosschecked for accuracy against the participants' raw data and frequencies were used to detect data entry errors. The data were then checked for missing values and then analyses were run to address the study questions.

Coding data. All questions were entered independently in SPSS. Fowler (2009) describes a code as "a set of rules that translates answers into numbers and vice versa" for computer analysis (p.145). Coding principles used in the present study included having missing data codes that differentiated between "not ascertained information," "inapplicable information," and a code indicating that the participant "didn't know" the information they were being asked. Consistency was used in assigning codes throughout the questionnaire to reduce errors, and codes were made to fit the data where possible, for example the code for a 31-year-old was " 31 " (Fowler, 2009; Polit \& Beck, 2004). In addition, for responses that reflected a range of values, the midpoint for the range was entered as the participant's response. For example, in response to the question regarding an appropriate appointment time for an acute condition, if the response was 20 to 30, 25 minutes was entered. The midpoint was selected to avoid skewing the results upward or downward; the midpoint response increases measurement reliability (Polit, 2010). 
Coding for "other" categories was an interactive process. Written responses were first analyzed to see if they fit into one of the provided categories to eliminate duplicate answers. Answers that did not fit into the provided categories were put into frequency tables to see how common they were among overall questionnaire responses (Polit \& Beck, 2004). New categories were created based on frequent responses ( $\geq 10$ responses) and were treated as an additional option to that question (Polit \& Beck, 2004). A separate code for "other" responses that did not fit into the defined coded categories was created and these different responses were analyzed. Notes were used to expand, clarify, and/or add a needed category to create mutually exclusive and exhaustive categories with corresponding codes (Fowler, 2009). Responses that were less frequent were grouped together under an "other" label.

For select questions, responses were grouped for certain analyses (e.g., t-tests) based on number of responses. The original coded question; however, was retained in the SPSS file. For example, NP education obtained was originally coded as four categories, but was collapsed into two categories for analysis due to the small number of responses in each category. See Appendix I for a summary table of each variable, the questions that address the variables, and how each question was scored in SPSS.

Missing data. Missing data represent an important issue in research, as they can negatively impact the reliability, validity, and generalizability of conclusions about relationships among variables (McKnight, McKnight, Sidani, \& Figueredo, 2007; Polit, 2010). Various approaches can be used to address missing data. Examples include substituting missing values with the mean, deleting cases only when they are missing data for a specific analysis (i.e., pairwise deletion), or deleting entire cases with a large amount of missing data (Polit, 2010). Polit (2010) suggests evaluating for the pattern (whether one or more items are missed 
consistently or randomly) and extent of missing data (the percent of missing values) before a decision is made.

Pairwise deletion was chosen to deal with the missing data. Pairwise deletion involves omitting cases (individual participants) from the analysis on a variable-by-variable basis (Polit, 2010). This option allowed the case to be excluded only if it was missing the data required for a specific analysis (Polit, 2010), and maintained sample size and power. In the present study, pairwise deletion was a better option than listwise deletion, which is the default setting for SPSS and may unnecessarily limit the sample size (Pallant, 2010; Polit, 2010).

During data entry, true missing data or "not ascertained information" were left as empty cells within the spreadsheet as SPSS is able to recognize blank cells as missing data (Pallant, 2010). Because some questions directed respondents to skip questions that were not applicable to them, non-response to these questions could not be avoided. These were coded as "zero" for "not applicable," as they were not true missing data. Using zero as a code did not impact the scoring of these skipped questions, as they were all nominal questions with categories scored with one or higher.

Once the data had been entered, the extent of missing data was assessed. For the majority of variables, missing data accounted for less than $10 \%$ of the data (range: $0.39-14.79 \%, M=$ $5.59 \%$, across the questionnaire). Each respondent was also assessed for missing data with a range of: $0.52-15.10 \%, M=7.65 \%$ across all items. Fox-Wasylyshyn and El-Masri (2005) suggest that a range of $10-40 \%$ of missing data for a given variable is acceptable before consideration of variable elimination. Pairwise deletion was therefore reasonable for this study, because the majority of instances of missing data involved less than $10 \%$ missing (two questions had approximately 14\% missing data), which didn't affect the inferences that could be made 
from the data and no variables were eliminated (Polit, 2010). Fox-Wasylyshyn \& El-Masri (2005) suggest that greater than $15 \%$ missing data may be considered high; however what is considered "high" is likely to depend on how important the variable is to the study.

Statistical analysis. Data analysis was conducted in three steps. The first step used descriptive statistics to describe the participants' responses to the questionnaire items. In the second step, a multiple regression analysis was conducted. The third step involved the analysis of relationships among variables using the appropriate statistical tests (based on each variable's level of measurement and distribution).

To begin, both the participants' demographic characteristics and their responses to questions pertaining to each variable were explored and described using descriptive statistics. Responses to nominal and ordinal questions (e.g., NPs' highest level of education and certification) were described using frequency distributions to investigate which answers occurred most often. Responses to interval and ratio level questions (e.g., NPs' years of experience) were analyzed using measures of central tendency including a mean and median, and measures of dispersion including standard deviation $(S D)$ and range. The mean and median are appropriate measures of central tendency for interval/ratio level data and offer the most succinct representation of the location of data within the distribution of scores (Grove et al., 2013). The $S D$ provides information about how far scores deviate from the mean (Grove et al., 2013).

The second step of data analysis occurred after frequency distributions were complete. Multiple regression analysis was used to examine which patient, NP, and organizational factors were the strongest predictors of NP patient panel size to answer secondary research questions 2 , 3, and 4. Multiple regression analysis is used with several IVs and one dependent variable (DV) to model the relationship among these variables (Grove et al., 2013). Multiple regression also 
allows the researcher to calculate the percentage of variance in the DV explained by the IVs by computing $R^{2}$ (the coefficient of determination; Polit, 2010). An $R^{2}$ close to 1 is desirable because it indicates that approximately all the variance in the DV is accounted for by the IVs; therefore, the IVs are considered to be good predictors of the DV. A low $R^{2}$ suggests that the IVs are poor predictors of the DV, and that the variance in the DV can be attributed to other factors, which may be unidentified. In nursing research, an $R^{2}$ of .40, which indicates that $40 \%$ of the variance in a DV can be explained by the IVs, is considered acceptable (Polit, 2010). The standardized regression coefficient $(\beta)$ also indicates how strongly each IV was associated with the DV (Polit, 2010). A strong association is indicated by a regression coefficient equal to or larger than .60 (Polit, 2010). Multicollinearity, a phenomenon where two or more predictor variables or IVs in a multiple regression model are highly correlated, is also a factor to consider (Draper \& Smith, 2003). A variance inflation factor (VIF) equal to or greater than 10 indicates moderate to high correlation among IVs (Draper \& Smith, 2003). Multicollinerity can be addressed by removing one of the variables from the model because they supply redundant information to the DV (Polit, 2010). Despite the robust nature of this statistical test, low variance in the DV and many of the IVs attenuates the relationships.

The third step of the statistical analysis involved analysis of relationships between each IV with the DV using inferential statistical tests such as independent sample t-tests and one-way analyses of variance (ANOVA). This third step was done because of the low variance in the DV and many of the IVs to detect relationships using multiple regression. IVs were selected for this third step of analysis by examining their frequencies, distribution, measures of central tendency (mean, median, and mode) and measures of dispersion (SD and range) to determine the amount of variance within each factor that could be associated with NP patient panel size (the DV). 
Depending on the level of measurement of the selected variable, independent samples t-tests, or ANOVA were used to examine relationships for nominal and ordinal IVs, respectively. An independent samples t-test was used to compare the mean scores of two different groups of NPs on the continuous DV (Grove et al., 2013). ANOVA is an extension of t-tests in that ANOVA compares data between two or more groups to investigate the presence of differences between those groups on a continuous DV (Grove et al., 2013). An $F$ statistic was produced that was compared to the $F$ distribution to determine whether the groups are significantly different from each other on the DV studied (Grove et al., 2013). Post-hoc tests were completed after the $F$ statistic was calculated to determine which group(s) differed from the others. There are several widely used post-hoc tests, including the Newman-Keuls test, Scheffé test, Tukey Honestly Significant Difference (HSD), Duncan's multiple-range test, and Fisher's significant difference (LSD) test. The Tukey HSD test was used in the present study, as it the most stringent (Grove et al., 2013; Polit, 2010). Pearson's product moment correlation coefficient (Pearson's $r$ ) was used to examine associations between interval and ratio IVs and the DV. The relative strength of each correlation coefficient ( $r$ ) was determined using Cohen's (1988) guidelines: a weak relationship is .00 to .29 , a moderate relationship is .30 to .49 , and a strong relationship is $>.50$. 


\section{Chapter 4: Results}

This chapter presents the study results. The first section describes the response rate, sociodemographic profile of the participants, and the descriptive statistics of the factors hypothesized to influence NP patient panel size. The second section presents the analyses pertaining to the research questions.

\section{Sample}

Response rate. Of the 573 total questionnaires distributed, 24 were excluded for various reasons: of these 20 NPs emailed or returned the questionnaire indicating that they no longer worked in PHC, three questionnaires were returned because the address was incorrect, and one respondent did not meet sampling inclusion criteria (NP worked in an outpatient unit in an acute care setting), leaving a total potential sample size of 549 NPs. It is reasonable to exclude these 24 NPs from the response rate calculation because they are not considered to be part of the target population (American Association for Public Opinion Research, 2000). Two hundred and eightythree questionnaires were returned, yielding a response rate of 52\% $(n=283$ returned out of 549 possible questionnaires).

Sociodemographic profile. In Table 1, demographic results are presented for NPs with their own patient panel, NPs without their own patient panel, and for the overall total sample of participants. There were approximate even numbers of NPs with and without their own patient panel. Of the 283 NPs who participated, most graduated from a PHC-NP certificate program, with the majority educated through a post-RN or post-baccalaureate NP program. Respondents were mostly women in their mid-forties. The most frequently described work settings were FHTs and CHCs. The majority of NPs were employed full time, worked some overtime hours, and were not members of a union. 
Table 1

Demographic Characteristics of NP Respondents

\begin{tabular}{|c|c|c|c|}
\hline Characteristic & $\begin{array}{c}\text { NPs With Own Panel } \\
(n=141)\end{array}$ & $\begin{array}{l}\text { NPs Without Own Panel } \\
\qquad(n=142)\end{array}$ & $\begin{array}{c}\text { Total } \\
(n=283)\end{array}$ \\
\hline \multicolumn{4}{|l|}{ Age (years) } \\
\hline Min, Max & $28.0,66.0$ & $29.0,65.0$ & $28.0,66.0$ \\
\hline Mean $(S D)$ & $47.5(10.6)$ & $45.8(9.9)$ & $46.6(10.3)$ \\
\hline Median & 49.0 & 46.0 & 47.0 \\
\hline \multicolumn{4}{|l|}{ Gender } \\
\hline Female & 132 & 132 & $264(93.3 \%)$ \\
\hline Male & 9 & 10 & $19(6.7 \%)$ \\
\hline \multicolumn{4}{|l|}{ NP category ${ }^{a}$} \\
\hline NP-PHC & 140 & 138 & $278(98.2 \%)$ \\
\hline NP-Adult & 3 & 6 & $9(3.2 \%)$ \\
\hline \multicolumn{4}{|l|}{$\begin{array}{l}\text { NP certification } \\
\text { program }\end{array}$} \\
\hline $\begin{array}{l}\text { Post-RN or Post- } \\
\text { Baccalaureate NP }\end{array}$ & 83 & 82 & $165(58.3 \%)$ \\
\hline $\begin{array}{r}\text { Master's or Post- } \\
\text { Master's NP }\end{array}$ & 52 & 56 & $108(38.2 \%)$ \\
\hline Other & 6 & 4 & $10(3.5 \%)$ \\
\hline \multicolumn{4}{|l|}{$\begin{array}{l}\text { Current practice } \\
\text { setting }\end{array}$} \\
\hline FHT & 35 & 96 & $131(46.5 \%)$ \\
\hline $\mathrm{CHC}$ & 65 & 24 & $89(31.4 \%)$ \\
\hline NPLC & 30 & 1 & $31(11.0 \%)$ \\
\hline AHAC & 6 & 7 & $13(4.6 \%)$ \\
\hline Other & 4 & 14 & $18(6.4 \%)$ \\
\hline \multicolumn{4}{|l|}{ Hours worked/week } \\
\hline \multicolumn{4}{|l|}{ Scheduled } \\
\hline Min, Max & $8.0,40.0$ & $1.5,80.0$ & $1.5,80.0$ \\
\hline Mean $(S D)$ & $34.72(6.3)$ & $32.36(11.8)$ & $33.49(9.5)$ \\
\hline Median & 37.0 & 35.0 & 36.0 \\
\hline \multicolumn{4}{|l|}{ Overtime } \\
\hline Min, Max & $0.0,20.0$ & $0.0,28.0$ & $0.0,28.0$ \\
\hline Mean $(S D)$ & $3.84(3.9)$ & $2.86(3.8)$ & $3.36(3.9)$ \\
\hline Median & 3.0 & 2.0 & 3.0 \\
\hline \multicolumn{4}{|l|}{ Union membership } \\
\hline Yes & 21 & 11 & $32(11.3 \%)$ \\
\hline No & 120 & 131 & $251(88.7 \%)$ \\
\hline
\end{tabular}

${ }^{a}$ Could select more than one category. 
Demographic characteristics were compared for NPs with a patient panel and those without a patient panel using an independent samples $t$-test or a non-parametric chi-square test for independence, depending on the level of measurement of the variable, to gain an understanding of any potential differences between these two groups of NPs. Of the demographic characteristics displayed in Table 1, employment status quantified by the number of scheduled hours worked per week $(t(280)=2.18, p=.05$, two tailed $)$ and current practice setting $\left(x^{2}(6, n=\right.$ $282)=80.16, p=.00, \mathrm{phi}=.53)$ were statistically significant, indicating NPs differ in employment status and current practice setting depending on whether they have their own patient panel or not.

\section{Findings for Patient, NP, and Organizational Factors}

The results for patient, NP, and organizational factors are described for NPs with their own patient panel, NPs without own patient panel, and the overall total sample of NP participants. Specific information about NP patient panels is then discussed.

Patient factors. The descriptive findings related to patient factors that may be associated with NP patient panel size are presented in Table 2 . The majority of NPs indicated that they saw patients from all age groups and that slightly more than half of patients seen are females. The most frequently presenting conditions were acute and multi-morbidities, followed by chronic and palliative conditions. NPs reported appointment times based on patient condition with the longest appointments reported for multi-morbid conditions. Additionally, NPs reported that the majority of their appointments were scheduled ahead of time, with only a small percentage of same-day visits. However, most same-day appointments were for patients that the NP already knew and/or had previously treated. NPs reported that the majority of patients in their practice were lowincome earners. 
Table 2

Characteristics of Patients Most Commonly Cared for by NPs

\begin{tabular}{|c|c|c|c|}
\hline Variable & $\begin{array}{l}\text { NPs With Own Panel } \\
\qquad(n=141)\end{array}$ & $\begin{array}{l}\text { NPs Without Own Panel } \\
\qquad(n=142)\end{array}$ & $\begin{array}{c}\text { Total } \\
(n=283)\end{array}$ \\
\hline \multicolumn{4}{|l|}{ Patient age } \\
\hline All ages & 110 & 105 & $215(76.0 \%)$ \\
\hline $\begin{array}{r}\text { Mainly children or } \\
\text { youth }(\leq 17)\end{array}$ & 1 & 1 & $2(0.7 \%)$ \\
\hline Mainly adults (18-64) & 20 & 24 & $44(15.5 \%)$ \\
\hline Mainly seniors $(65+)$ & 10 & 11 & $21(7.4 \%)$ \\
\hline \multicolumn{4}{|l|}{ Patient gender } \\
\hline Female & 70 & 87 & $157(55.5 \%)$ \\
\hline Male & 10 & 7 & $17(6.0 \%)$ \\
\hline Mixture of genders & 61 & 46 & $107(37.8 \%)$ \\
\hline \multicolumn{4}{|l|}{ Socioeconomic status } \\
\hline Low income & 75 & 50 & $125(44.1 \%)$ \\
\hline Middle income & 22 & 41 & $63(22.3 \%)$ \\
\hline High income & 1 & 2 & $3(1.1 \%)$ \\
\hline Mixture of incomes & 43 & 49 & $92(32.5 \%)$ \\
\hline \multicolumn{4}{|l|}{ Health status $(\%)$} \\
\hline \multicolumn{4}{|l|}{ Acute condition } \\
\hline Min, Max & $4.0,87.0$ & $0.0,95.0$ & $0.0,95.0$ \\
\hline Mean $(S D)$ & $27.35(15.5)$ & $39.83(21.4)$ & $33.6(19.7)$ \\
\hline Median & 25.0 & 40.0 & 30.0 \\
\hline \multicolumn{4}{|l|}{ Chronic condition } \\
\hline Min, Max & $0.0,70.0$ & $0.0,90.0$ & $0.0,90.0$ \\
\hline Mean $(S D)$ & $30.49(13.8)$ & $29.54(14.8)$ & $30.0(14.3)$ \\
\hline Median & 30.0 & 30.0 & 30.0 \\
\hline \multicolumn{4}{|l|}{ Multi-morbidities } \\
\hline Min, Max & $3.0,90.0$ & $0.0,90.0$ & $0.0,90.0$ \\
\hline Mean $(S D)$ & $38.91(20.0)$ & $28.37(18.7)$ & $33.6(20.0)$ \\
\hline Median & 36.3 & 25.0 & 30.0 \\
\hline \multicolumn{4}{|l|}{ Palliative } \\
\hline Min, Max & $0.0,20.0$ & $0.0,30.0$ & $0.0,30.0$ \\
\hline Mean $(S D)$ & $3.18(4.2)$ & $2.7(4.6)$ & $2.9(4.4)$ \\
\hline Median & 1.0 & 1.0 & 1.0 \\
\hline \multirow{2}{*}{\multicolumn{4}{|c|}{$\begin{array}{l}\text { Health status } \\
\text { appointment time } \\
\text { (minutes) } \\
\text { Acute condition }\end{array}$}} \\
\hline & & & \\
\hline Min, Max & $15.0,45.0$ & $10.0,45.0$ & $10.0,45.0$ \\
\hline Mean $(S D)$ & $23.62(6.4)$ & $21.21(6.5)$ & $22.4(6.6)$ \\
\hline Median & 20.0 & 20.0 & 20.0 \\
\hline
\end{tabular}




\begin{tabular}{|c|c|c|c|}
\hline Variable & $\begin{array}{l}\text { NPs With Own Panel } \\
(n=141)\end{array}$ & $\begin{array}{l}\text { NPs Without Own Panel } \\
\qquad(n=142)\end{array}$ & $\begin{array}{c}\text { Total } \\
(n=283)\end{array}$ \\
\hline \multicolumn{4}{|l|}{ Single chronic illness } \\
\hline Min, Max & $15.0,60.0$ & $15.0,60.0$ & $15.0,60.0$ \\
\hline Mean $(S D)$ & $29.91(7.4)$ & $27.1(7.6)$ & $28.9(7.5)$ \\
\hline Median & 30.0 & 30.0 & 30.0 \\
\hline \multicolumn{4}{|l|}{ Co-morbidity } \\
\hline Min, Max & $15.0,60.0$ & $15.0,60.0$ & $15.0,60.0$ \\
\hline Mean $(S D)$ & $30.28(8.0)$ & $28.57(7.7)$ & $29.4(7.9)$ \\
\hline Median & 30.0 & 30.0 & 30.0 \\
\hline \multicolumn{4}{|l|}{ Multi-morbidities } \\
\hline Min, Max & $15.0,75.0$ & $15.0,90.0$ & $15.0,90.0$ \\
\hline Mean $(S D)$ & $35.87(11.7)$ & $33.51(13.3)$ & $34.7(12.6)$ \\
\hline Median & 30.0 & 30.0 & 30.0 \\
\hline \multicolumn{4}{|l|}{ Mental health } \\
\hline Min, Max & $15.0,60.0$ & $15.0,60.0$ & $15.0,60.0$ \\
\hline Mean $(S D)$ & $32.59(8.7)$ & $31.34(9.3)$ & $31.9(9.0)$ \\
\hline Median & 30.0 & 30.0 & 30.0 \\
\hline \multicolumn{4}{|l|}{$\begin{array}{l}\text { Mental health \& } \\
\text { chronic illness }\end{array}$} \\
\hline Min, Max & $20.0,60.0$ & $15.0,60.0$ & $15.0,60.0$ \\
\hline Mean $(S D)$ & $35.62(11.2)$ & $32.55(10.7)$ & $34.1(11.0)$ \\
\hline Median & 30.0 & 30.0 & 30.0 \\
\hline \multicolumn{4}{|l|}{ Palliative care } \\
\hline Min, Max & $20.0,90.0$ & $15.0,90.0$ & $15.0,90.0$ \\
\hline Mean $(S D)$ & $38.26(14.4)$ & $36.4(15.3)$ & $37.4(14.8)$ \\
\hline Median & 30.0 & 30.0 & 30.0 \\
\hline \multicolumn{4}{|l|}{$\begin{array}{l}\text { Appointment time by } \\
\text { gender (minutes) }\end{array}$} \\
\hline \multicolumn{4}{|l|}{ Female } \\
\hline Min, Max & $15.0,60.0$ & $10.0,60.0$ & $10.0,60.0$ \\
\hline Mean $(S D)$ & $30.1(9.4)$ & $28.04(9.4)$ & $28.9(8.6)$ \\
\hline Median & 30.0 & 30.0 & 30.0 \\
\hline \multicolumn{4}{|l|}{ Male } \\
\hline Min, Max & $15.0,38.0$ & $20.0,30.0$ & $20.0,38.0$ \\
\hline Mean $(S D)$ & $31.07(2.8)$ & $27.14(4.9)$ & $29.1(4.3)$ \\
\hline Median & 30.0 & 30.0 & 30.0 \\
\hline \multicolumn{4}{|l|}{ Mixture of genders } \\
\hline Min, Max & $15.0,45.0$ & $15.0,60.0$ & $15.0,60.0$ \\
\hline Mean $(S D)$ & $30.19(6.9)$ & $27.18(9.3)$ & $28.9(8.1)$ \\
\hline Median & 30.0 & 30.0 & 30.0 \\
\hline \multicolumn{4}{|l|}{$\begin{array}{l}\text { Same-day patient } \\
\text { visits }\end{array}$} \\
\hline $\begin{array}{r}\text { Patients who the NP } \\
\text { has previously treated }\end{array}$ & 89 & 69 & $158(55.8 \%)$ \\
\hline
\end{tabular}




\begin{tabular}{|c|c|c|c|}
\hline Variable & $\begin{array}{l}\text { NPs With Own Panel } \\
\qquad(n=141)\end{array}$ & $\begin{array}{l}\text { NPs Without Own Panel } \\
\qquad(n=142)\end{array}$ & $\begin{array}{c}\text { Total } \\
(n=283)\end{array}$ \\
\hline $\begin{array}{r}\text { Patients are new to the } \\
\text { NP, but known to the } \\
\text { practice }\end{array}$ & 38 & 61 & $99(35.0 \%)$ \\
\hline $\begin{array}{l}\text { Patients are new to the } \\
\text { NP and the practice }\end{array}$ & 4 & 4 & $8(2.8 \%)$ \\
\hline $\begin{array}{r}\text { NP does not have } \\
\text { same-day patient } \\
\text { visits }\end{array}$ & 3 & 4 & $7(2.5 \%)$ \\
\hline $\begin{array}{r}\text { Combination of more } \\
\text { than one option }\end{array}$ & 7 & 4 & $11(3.9 \%)$ \\
\hline \multicolumn{4}{|l|}{$\begin{array}{l}\text { Same day } \\
\text { appointments }(\%)\end{array}$} \\
\hline Min, Max & $20.0,89.0$ & $30.0,100.0$ & $0.0,100.0$ \\
\hline Mean $(S D)$ & $24.21(18.9)$ & $31.54(26.1)$ & $27.9(23.1)$ \\
\hline Median & 20.0 & 30.0 & 20.0 \\
\hline
\end{tabular}


NP factors. The descriptive results for the NP factors for NPs with and without a patient panel are reported in Table 3 . Of the 283 NPs who participated, slightly more than half had a graduate-level education and the remainder were educated at the diploma or baccalaureate level. Respondents had a wide range of prior RN nursing experience, nearly 10 years of NP experience in total, and six years of experience in their current practice setting. The majority of NPs were employed full time and saw patients on average four days per week $(S D=1.1)$ whether they had a patient panel or not. The NPs reported using different formats in their encounters with patients. Faxing, emailing, and texting patients were not as common as in-person appointments; however, those that did email patients $(n=59 ; 21 \%)$ did so with an average of two $(S D=1.9)$ patients per day, those who faxed patients $(n=41 ; 14 \%)$ did so an average of six $(S D=6.2)$ patients per day, and those who texted patients $(n=12 ; 4 \%)$ did so an average of two $(S D=1.3)$ patients per day. Lastly, almost all $(n=278 ; 98 \%)$ NPs described their understanding of their role within the healthcare team as 'excellent' or 'good'. 
Table 3

Characteristics of NPS

\begin{tabular}{|c|c|c|c|}
\hline Variable & $\begin{array}{l}\text { NPs With Own Panel } \\
\qquad(n=141)\end{array}$ & $\begin{array}{l}\text { NPs Without Own Panel } \\
\qquad(n=142)\end{array}$ & $\begin{array}{c}\text { Total } \\
(n=283)\end{array}$ \\
\hline \multicolumn{4}{|l|}{ Highest education } \\
\hline Master's & 72 & 74 & $146(51.6 \%)$ \\
\hline Baccalaureate & 62 & 62 & $124(43.8 \%)$ \\
\hline Diploma & 4 & 5 & $9(3.2 \%)$ \\
\hline Doctorate & 3 & 1 & $4(1.4 \%)$ \\
\hline \multicolumn{4}{|l|}{$\begin{array}{l}\text { Experience as a NP } \\
\text { (years) }\end{array}$} \\
\hline Min, Max & $2.0,33.0$ & $1.0,44.0$ & $1.0,44.0$ \\
\hline Mean $(S D)$ & $9.66(5.7)$ & $9.59(6.8)$ & $9.62(6.3)$ \\
\hline Median & 8.0 & 8.0 & 8.0 \\
\hline \multicolumn{4}{|l|}{$\begin{array}{l}\text { Experience in current } \\
\text { practice setting } \\
\text { (years) }\end{array}$} \\
\hline Min, Max & $0.17,33.0$ & $0.08,38.0$ & $0.8,38.0$ \\
\hline Mean $(S D)$ & $6.18(4.8)$ & $5.57(4.5)$ & $5.87(4.6)$ \\
\hline Median & 5.0 & 5.0 & 5.0 \\
\hline \multicolumn{4}{|l|}{ Prior RN experience } \\
\hline Hospital/Acute Care & 63 & 75 & $138(48.8 \%)$ \\
\hline Community Nursing & 38 & 39 & $79(27.9 \%)$ \\
\hline Outpost Nursing & 17 & 8 & $25(8.8 \%)$ \\
\hline Administration & 9 & 1 & $10(3.5 \%)$ \\
\hline Education & 2 & 8 & $10(3.5 \%)$ \\
\hline Long-Term Care & 4 & 3 & $7(2.5 \%)$ \\
\hline More than one area & 4 & 2 & $6(2.1 \%)$ \\
\hline Other & 3 & 5 & $8(2.9 \%)$ \\
\hline \multicolumn{4}{|l|}{ Employment status } \\
\hline $\begin{array}{r}\text { Full Time }(\geq 35 \\
\text { hours/week })\end{array}$ & 101 & 76 & $193(68.2 \%)$ \\
\hline $\begin{array}{r}\text { Part Time }(21-34 \\
\text { hours/week })\end{array}$ & 28 & 56 & $84(29.7 \%)$ \\
\hline $\begin{array}{r}\text { Casual/Locum }(\leq 20 \\
\text { hours/week })\end{array}$ & 0 & 6 & $6(2.1 \%)$ \\
\hline \multirow{2}{*}{\multicolumn{4}{|c|}{$\begin{array}{l}\text { Number of patients } \\
\text { seen per day }\end{array}$}} \\
\hline & & & \\
\hline Min, Max & $4.0,45.0$ & $3.0,45.0$ & $3.0,45.0$ \\
\hline Mean $(S D)$ & $12.4(4.6)$ & $14.3(7.7)$ & $13.3(6.4)$ \\
\hline Median & 12.0 & 13.7 & 12.0 \\
\hline
\end{tabular}




\begin{tabular}{|c|c|c|c|}
\hline Variable & $\begin{array}{l}\text { NPs With Own Panel } \\
\qquad(n=141)\end{array}$ & $\begin{array}{l}\text { NPs Without Own Panel } \\
\qquad(n=142)\end{array}$ & $\begin{array}{c}\text { Total } \\
(n=283)\end{array}$ \\
\hline \multicolumn{4}{|l|}{ Telephone } \\
\hline Min, Max & $0.0,15.0$ & $0.0,10.0$ & $0.0,15.0$ \\
\hline Mean $(S D)$ & $4.06(2.9)$ & $4.22(2.5)$ & $4.1(2.7)$ \\
\hline Median & 3.0 & 4.0 & 4.0 \\
\hline \multicolumn{4}{|l|}{ Email } \\
\hline Min, Max & $0.0,5.0$ & $0.0,11.0$ & $0.0,11.0$ \\
\hline Mean $(S D)$ & $0.47(1.0)$ & $0.4(1.3)$ & $0.4(1.2)$ \\
\hline Median & 0.0 & 0.0 & 0.0 \\
\hline \multicolumn{4}{|l|}{ Fax } \\
\hline Min, Max & $0.0,30.0$ & $0.0,20.0$ & $0.0,30.0$ \\
\hline Mean $(S D)$ & $1.06(3.7)$ & $0.77(2.8)$ & $0.9(3.2)$ \\
\hline Median & 0.0 & 0.0 & 0.0 \\
\hline \multicolumn{4}{|l|}{ Text } \\
\hline Min, Max & $0.0,5.0$ & $0.0,3.0$ & $0.0,5.0$ \\
\hline Mean $(S D)$ & $0.07(0.5)$ & $0.08(0.4)$ & $0.1(0.4)$ \\
\hline Median & 0.0 & 0.0 & 0.0 \\
\hline
\end{tabular}


Organizational factors. Table 4 presents the descriptive findings for organizational factors for NPs with and without a patient panel. The majority of NPs reported working at a clinic located within a city with approximately four $(S D=4.7)$ affiliated sites. However, the majority $(n=210 ; 74 \%)$ of these NPs only worked at one of the sites. Seventy-three (26\%) respondents reported working between clinical sites that had an average of two hours $(S D=2.3)$ of travel time. NPs reported that despite the availability of other staff, NPs were consistently responsible for duties such as greeting and escorting patients from the waiting room to their exam room and/or office $(n=209 ; 74 \%)$ and cleaning and preparing exam rooms between patient uses $(n=190 ; 67 \%)$. Almost all NPs $(n=278 ; 98 \%)$ indicated that they used an EMR for activities such as ordering laboratory and/or diagnostic imaging, documenting, or viewing patient notes from other providers an average of more than four times $(M=4.6 ; S D=1.0)$ per week.

In addition, 57 (20\%) NPs indicated that group visits were a part of their practice with chronic illness groups being the most frequent type of group and scheduled on average for 60 minutes $(S D=30.1)$. NPs also reported completing indirect care activities such as consultations with other providers and team meetings about patient care on average 1.5 times $(S D=1.1)$ per week, whether they had a patient panel or not. NPs' reported satisfaction with interdisciplinary team functioning was relatively high and similar whether the NP had a patient panel or not, with a mean score of $28.4(S D=6.1)$ out of 35.0 for team functioning aspects such as communication, frequency of team meetings, and the team's understanding of the NPs' role. 
Table 4

Characteristics of Organizations Where NPs Work

\begin{tabular}{|c|c|c|c|}
\hline Variable & $\begin{array}{l}\text { NPs With Own Panel } \\
\qquad(n=141)\end{array}$ & $\begin{array}{l}\text { NPs Without Own Panel } \\
\qquad(n=142)\end{array}$ & $\begin{array}{c}\text { Total } \\
(n=283)\end{array}$ \\
\hline \multicolumn{4}{|l|}{ Practice location } \\
\hline City/Inner-city & 92 & 80 & $172(60.8 \%)$ \\
\hline Small town & 22 & 27 & $49(17.3 \%)$ \\
\hline Rural & 26 & 34 & $60(21.2 \%)$ \\
\hline Remote & 1 & 1 & $2(0.7 \%)$ \\
\hline \multicolumn{4}{|l|}{ Number of exam rooms } \\
\hline Min, Max & $1.0,6.0$ & $1.0,24.0$ & $1.0,24.0$ \\
\hline Mean $(S D)$ & $1.41(0.8)$ & $1.93(2.7)$ & $1.67(2.0)$ \\
\hline Median & 1.0 & 1.0 & 1.0 \\
\hline \multicolumn{4}{|l|}{$\begin{array}{l}\text { Healthcare team } \\
\text { members }^{\mathrm{a}}\end{array}$} \\
\hline Physician(s) & 133 & 139 & $272(96.1 \%)$ \\
\hline Receptionist(s) & 130 & 131 & $261(92.2 \%)$ \\
\hline $\mathrm{RN}(\mathrm{s})$ & 120 & 114 & $234(82.7 \%)$ \\
\hline Manager/Administrator(s) & 110 & 104 & $214(75.6 \%)$ \\
\hline Clerical Staff & 89 & 97 & $186(65.7 \%)$ \\
\hline $\mathrm{RPN}(\mathrm{s})$ & 82 & 80 & $162(57.2 \%)$ \\
\hline Counselor(s) & 63 & 86 & $149(52.7 \%)$ \\
\hline Dietician(s) & 87 & 60 & $147(51.9 \%)$ \\
\hline Social Worker(s) & 78 & 60 & $138(48.8 \%)$ \\
\hline Housekeeping & 39 & 39 & $78(27.6 \%)$ \\
\hline Pharmacist(s) & 32 & 29 & $61(21.6 \%)$ \\
\hline Community Worker(s) & 22 & 9 & $31(11.0 \%)$ \\
\hline Physiotherapist(s) & 20 & 8 & $28(9.9 \%)$ \\
\hline Chiropody/Foot Care & 15 & 12 & $27(9.5 \%)$ \\
\hline Respiratory Therapist(s) & 12 & 9 & $21(7.4 \%)$ \\
\hline Other & 38 & 44 & $82(28.9 \%)$ \\
\hline \multicolumn{4}{|l|}{ NP sees patients at } \\
\hline Patient home & 84 & 70 & $154(54.4 \%)$ \\
\hline Long-term care & 17 & 21 & $38(13.4 \%)$ \\
\hline School & 12 & 7 & $19(6.7 \%)$ \\
\hline Shelter & 13 & 3 & $16(5.7 \%)$ \\
\hline Street health & 4 & 2 & $6(2.1 \%)$ \\
\hline Hospital & 2 & 2 & $4(1.4 \%)$ \\
\hline Other & 17 & 6 & $23(8.2 \%)$ \\
\hline \multicolumn{4}{|l|}{$\begin{array}{l}\text { Home visits (hours per } \\
\text { week) }\end{array}$} \\
\hline Min, Max & $0.23,28.0$ & $0.25,30.0$ & $0.23,30.0$ \\
\hline Mean $(S D)$ & $2.21(4.2)$ & $3.16(5.9)$ & $2,64(5.1)$ \\
\hline
\end{tabular}




\begin{tabular}{|c|c|c|c|}
\hline Variable & $\begin{array}{l}\text { NPs With Own Panel } \\
\qquad(n=141)\end{array}$ & $\begin{array}{l}\text { NPs Without Own Panel } \\
\qquad(n=142)\end{array}$ & $\begin{array}{c}\text { Total } \\
(n=283)\end{array}$ \\
\hline Median & 1.0 & 1.0 & 1.0 \\
\hline \multicolumn{4}{|l|}{$\begin{array}{l}\text { Home Visits (number of } \\
\text { patients per week) }\end{array}$} \\
\hline Min, Max & $0.25,60.0$ & $0.25,14.0$ & $0.25,60.0$ \\
\hline Mean $(S D)$ & $3.1(8.1)$ & $2.67(2.8)$ & $2.9(2.8)$ \\
\hline Median & 1.0 & 2.0 & 1.0 \\
\hline \multicolumn{4}{|l|}{$\begin{array}{l}\text { Hours per week NP } \\
\text { spends travelling to } \\
\text { patient visits }\end{array}$} \\
\hline Min, Max & $0.08,8.0$ & $0.05,30.0$ & $0.05,30.0$ \\
\hline Mean $(S D)$ & $1.06(1.0)$ & $1.68(3.9)$ & $1.32(2.7)$ \\
\hline Median & 1.0 & 1.0 & 1.0 \\
\hline \multicolumn{4}{|l|}{$\begin{array}{l}\text { Interdisciplinary Team: } \\
\text { Time it takes to obtain an } \\
\text { urgent consult within } \\
\text { NP's practice setting }\end{array}$} \\
\hline Within 15 minutes & 69 & 85 & $154(54.4 \%)$ \\
\hline Within 1 hour & 31 & 29 & $60(21.2 \%)$ \\
\hline Within 4 hours & 11 & 5 & $16(5.7 \%)$ \\
\hline Within 1 day & 23 & 15 & $38(13.4 \%)$ \\
\hline Within 1 week & 3 & 4 & $7(2.5 \%)$ \\
\hline Varies & 2 & 4 & $6(2.1 \%)$ \\
\hline Not applicable & 2 & 0 & $2(0.7 \%)$ \\
\hline \multicolumn{4}{|l|}{$\begin{array}{l}\text { Interdisciplinary Team: } \\
\text { Occurrence of patient } \\
\text { problems due to } \\
\text { uncoordinated care within } \\
\text { NP's practice setting }\end{array}$} \\
\hline Daily & 3 & 1 & $4(1.4 \%)$ \\
\hline Weekly & 18 & 12 & $30(10.6 \%)$ \\
\hline Monthly & 12 & 20 & $32(11.3 \%)$ \\
\hline Quarterly & 19 & 30 & $49(17.3 \%)$ \\
\hline Annually & 4 & 5 & $9(3.2 \%)$ \\
\hline Less than once per year & 45 & 36 & $81(28.6 \%)$ \\
\hline Never & 19 & 16 & $35(12.4 \%)$ \\
\hline Unsure & 13 & 15 & $28(9.9 \%)$ \\
\hline Occasionally & 7 & 5 & $12(4.2 \%)$ \\
\hline Not applicable & 1 & 2 & $3(1.1 \%)$ \\
\hline \multicolumn{4}{|l|}{$\begin{array}{l}\text { NP-Physician } \\
\text { collaboration within NP's } \\
\text { practice setting: NP } \\
\text { satisfaction }\end{array}$} \\
\hline Min, Max & $1.0,5.0$ & $1.0,5.0$ & $1.0,5.0$ \\
\hline
\end{tabular}




\begin{tabular}{|c|c|c|c|}
\hline Variable & $\begin{array}{c}\text { NPs With Own Panel } \\
\qquad(n=141)\end{array}$ & $\begin{array}{l}\text { NPs Without Own Panel } \\
\qquad(n=142)\end{array}$ & $\begin{array}{c}\text { Total } \\
(n=283)\end{array}$ \\
\hline Mean $(S D)$ & $4.41(0.9)$ & $4.48(0.9)$ & $4.45(0.9)$ \\
\hline Median & 5.0 & 5.0 & 5.0 \\
\hline \multicolumn{4}{|l|}{$\begin{array}{l}\text { NP-Physician } \\
\text { collaboration outside of } \\
\text { NP's practice setting: } \\
\text { Time information is } \\
\text { received back from } \\
\text { specialist }\end{array}$} \\
\hline $\begin{array}{l}\text { Sufficiently fast for } \\
\text { optimal patient care }\end{array}$ & 31 & 43 & $74(26.1 \%)$ \\
\hline $\begin{array}{r}\text { Information is delayed } \\
\text { but does not hinder ability } \\
\text { to care for patient }\end{array}$ & 67 & 70 & $137(48.4 \%)$ \\
\hline $\begin{array}{l}\text { Information is delayed } \\
\text { and hinders ability to care } \\
\text { for patients efficiently }\end{array}$ & 41 & 26 & $67(23.7 \%)$ \\
\hline $\begin{array}{r}\text { Information is delayed } \\
\text { and has negative effects } \\
\text { on patient health } \\
\text { outcomes }\end{array}$ & 2 & 3 & $5(1.8 \%)$ \\
\hline $\begin{array}{l}\text { NP Scope of Practice } \\
\text { Amount of NP } \\
\text { knowledge \& skills used }\end{array}$ & \multicolumn{3}{|c|}{$\begin{array}{l}\text { Amount of NP } \\
\text { knowledge \& skills used }\end{array}$} \\
\hline Min, Max & $3.0,4.0$ & $1.0,4.0$ & $1.0,4.0$ \\
\hline Mean $(S D)$ & $3.72(0.7)$ & $3.38(0.9)$ & $3.55(0.8)$ \\
\hline Median & 4.0 & 4.0 & 4.0 \\
\hline \multicolumn{4}{|l|}{$\begin{array}{l}\text { Opportunities for } \\
\text { continuing education }\end{array}$} \\
\hline Min, Max & $1.0,5.0$ & $1.0,5.0$ & $1.0,5.0$ \\
\hline Mean (SD) & $3.9(1.0)$ & $4.1(1.4)$ & $4.0(1.2)$ \\
\hline \multicolumn{4}{|l|}{$\begin{array}{l}\text { Autonomy to make } \\
\text { clinical decisions }\end{array}$} \\
\hline Min, Max & $1.0,5.0$ & $1.0,5.0$ & $1.0,5.0$ \\
\hline Mean $(S D)$ & $4.8(0.4)$ & $4.6(1.0)$ & $4.7(0.7)$ \\
\hline \multicolumn{4}{|l|}{$\begin{array}{r}\text { Autonomy to decide time } \\
\text { with patient }\end{array}$} \\
\hline Min, Max & $1.0,5.0$ & $1.0,5.0$ & $1.0,5.0$ \\
\hline Mean $(S D)$ & $4.4(1.0)$ & $3.8(1.6)$ & $4.1(1.3)$ \\
\hline Overall job & & & \\
\hline Min, Max & $1.0,5.0$ & $1.0,5.0$ & $1.0,5.0$ \\
\hline Mean $(S D)$ & $4.4(1.0)$ & $4.2(1.0)$ & $4.3(1.0)$ \\
\hline Overall satisfaction score & $17.5(3.2)$ & $16.7(3.0)$ & $17.1(3.1)$ \\
\hline
\end{tabular}




\begin{tabular}{|c|c|c|c|}
\hline Variable & $\begin{array}{l}\text { NPs With Own Panel } \\
\qquad(n=141)\end{array}$ & $\begin{array}{l}\text { NPs Without Own Panel } \\
\qquad(n=142)\end{array}$ & $\begin{array}{c}\text { Total } \\
(n=283)\end{array}$ \\
\hline \multicolumn{4}{|l|}{$\begin{array}{l}\text { Interdisciplinary Team } \\
\text { and practice: NP agrees } \\
\text { with }\end{array}$} \\
\hline \multicolumn{4}{|l|}{$\begin{array}{r}\text { Team members provide } \\
\text { useful ideas to enable NP } \\
\text { practice }\end{array}$} \\
\hline Min, Max & $1.0,5.0$ & $1.0,5.0$ & $1.0,5.0$ \\
\hline Mean $(S D)$ & $4.4(1.0)$ & $4.2(0.8)$ & $4.3(0.9)$ \\
\hline \multicolumn{4}{|l|}{$\begin{array}{r}\text { Team members question } \\
\text { decisions and direction of } \\
\text { the practice }\end{array}$} \\
\hline Min, Max & $1.0,5.0$ & $1.0,5.0$ & $1.0,5.0$ \\
\hline Mean $(S D)$ & $4.0(1.1)$ & $2.8(1.5)$ & $3.4(1.3)$ \\
\hline \multicolumn{4}{|l|}{$\begin{array}{r}\text { The practice seeks to } \\
\text { improve }\end{array}$} \\
\hline Min, Max & $1.0,5.0$ & $1.0,5.0$ & $1.0,5.0$ \\
\hline Mean $(S D)$ & $3.8(1.0)$ & $4.0(1.4)$ & $3.9(1.2)$ \\
\hline \multicolumn{4}{|l|}{$\begin{array}{l}\text { It's hard to make change } \\
\text { in this practice }\end{array}$} \\
\hline Min, Max & $1.0,5.0$ & $1.0,5.0$ & $1.0,5.0$ \\
\hline Mean $(S D)$ & $2.6(1.2)$ & $2.6(1.6)$ & $2.6(1.4)$ \\
\hline Total amount NPs agree & $14.8(3.0)$ & $13.6(3.2)$ & $14.1(3.1)$ \\
\hline
\end{tabular}

${ }^{a}$ Could select more than one category. 
NP patient panel size. Table 5 presents results regarding NP patient panel size. Of the 283 NP respondents, $50 \%(n=141)$ stated they had their own patient panel, the remainder stated they did not have their own patient panel $(n=50 ; 18 \%)$ and/or shared the panel with one or more physicians or other NPs $(n=92 ; 33 \%)$. Those who reported they shared a patient panel had an average of 3639 patients $(S D=4058)$; however, it was unclear as to the number of providers with whom they shared the panel. Those who stated they did not have their own patient panel $(n$ $=50)$ did not complete the remaining questions around patient panel size.

Of those NPs who had their own patient panel, the average NP patient panel size was 502 patients $(S D=252)$ patients; however, six NPs did not provide a specific patient panel number and were excluded from further analyses. A variety of approaches were used to assign patients to the NPs who had their own patient panel, but the majority of patients were assigned to the NP panel at the time of booking an appointment with the NP and/or assigned by the receptionist. A portion of NPs $(n=100 ; 71 \%)$ who had their own panel stated that their organization did not have specific NP panel size expectations. For NPs in organizations that did $(n=41 ; 29 \%)$, the average panel size expectation was 696 patients $(S D=153.5)$. Many NPs $(n=102 ; 72 \%)$ reported that there was no formal method of adjusting for patient complexity within their panel size determination; a few $(n=39 ; 28 \%)$ indicated that a patient complexity scoring method, the Standardized Adjustment Clinical Group Morbidity Index (SAMI), was used to adjust NP patient panel size. 
Table 5

Characteristics of NP Patient Panel Size

\begin{tabular}{|c|c|c|c|}
\hline Variable & $\begin{array}{c}\text { NPs with Own Panel } \\
(n=141)\end{array}$ & $\begin{array}{l}\text { NPs With Shared Panel } \\
\qquad(n=92)\end{array}$ & $\begin{array}{c}\text { Total } \\
(n=233)\end{array}$ \\
\hline \multicolumn{4}{|l|}{$\begin{array}{l}\text { Primary way patients } \\
\text { assigned to NP patient panel }\end{array}$} \\
\hline $\begin{array}{r}\text { Patients book appointments } \\
\text { with the NP }\end{array}$ & 141 & 24 & $165(70.8)$ \\
\hline Receptionist assigns & 100 & 17 & $117(50.2)$ \\
\hline $\begin{array}{r}\text { Patients see NP because } \\
\text { physician unavailable }\end{array}$ & 14 & 75 & $89(38.1)$ \\
\hline $\begin{array}{r}\text { Referral from a colleague } \\
\text { within clinic }\end{array}$ & 37 & 38 & $75(32.2)$ \\
\hline Team meetings & 13 & 14 & $27(11.6)$ \\
\hline Referral from another site & 10 & 12 & $22(9.4)$ \\
\hline Clinical leadership assigns & 5 & 5 & $10(4.3)$ \\
\hline Other & 3 & 6 & $9(3.9)$ \\
\hline \multicolumn{4}{|l|}{$\begin{array}{l}\text { NPs at maximum patient } \\
\text { panel size }\end{array}$} \\
\hline Yes & 30 & 32 & $62(26.6)$ \\
\hline No & 111 & 60 & $171(73.4)$ \\
\hline \multicolumn{4}{|l|}{$\begin{array}{l}\text { Organization panel size } \\
\text { expectations }\end{array}$} \\
\hline$T_{-1}$ & 41 & 42 & $83(35.6)$ \\
\hline No & 100 & 50 & $150(64.4)$ \\
\hline \multicolumn{4}{|l|}{ Method to adjust panel size } \\
\hline Yes & 39 & 10 & $49(21.0)$ \\
\hline No & 102 & 82 & $184(78.9)$ \\
\hline
\end{tabular}




\section{Influence of Factors on NP Patient Panel Size}

Three multiple regression models were planned to answer secondary research questions 2, 3, and 4 regarding which patient, NP, and organizational factor(s) had the strongest association with NP patient panel size. Data were first examined to determine if they met the assumptions of multiple regression. Specifically: a normal distribution, no outliers, no or low multicollinearity, and adequate variability (Pallant, 2010). Both the DV (NP patient panel size) and many of the IVs did not have sufficient variability to complete the three regression models as originally planned. For example, NP role clarity was not normally distributed, as almost all NPs (>90\%) selected the same answer. Additionally, all of the 135 NPs who reported their patient panel sizes indicated between 300 to 500 patients, with little variability within the DV and many of the IVs to identify statistically significant relationships. While there may be important relationships present, this sample provided too little variability in the IVs and DV to run meaningful multiple regression analysis. The implications of this finding will be discussed further in Chapter 5 .

\section{Analysis of NP Patient Panel Size by PHC Practice Model}

A cross tabulation table comparing the PHC practice model and whether or not the NP had their own panel was completed to gain an understanding of the PHC models in which NPs were more likely to have a patient panel (see Table 6). This cross tabulation was completed prior to inferential statistical analysis to facilitate understanding of the potential relationships contextual factors with panel size described in the next sections. From this cross tabulation table it is clear that NPs practicing in CHCs and NPLCs were more likely to have their own panel of patients. NPs were less likely to have a patient panel if they worked in models in which physicians are more likely to be in a position of authority over the NP and/or with physicians 
who rely on fee-for-service remuneration, such as FHTs, physician offices, walk-in clinics, and specialty PHC clinics. 
Table 6

PHC Practice Model and Existence of Independent NP Patient Panel Relationship

\begin{tabular}{|c|c|c|c|c|c|}
\hline \multicolumn{6}{|c|}{ NP Has Own Patient Panel } \\
\hline \multirow{2}{*}{$\begin{array}{c}\text { PHC Practice } \\
\text { Model }\end{array}$} & \multicolumn{2}{|c|}{ Yes } & \multicolumn{2}{|c|}{ No } & \multirow{2}{*}{$\begin{array}{c}\text { Total } \\
n\end{array}$} \\
\hline & $n$ & $\%$ & $n$ & $\%$ & \\
\hline $\begin{array}{l}\text { Aboriginal Health } \\
\text { Access Center }\end{array}$ & 6 & 46.2 & 7 & 53.8 & 13 \\
\hline $\begin{array}{l}\text { Community Health } \\
\text { Centre }\end{array}$ & 65 & 73.0 & 24 & 27.0 & 89 \\
\hline Family Health Team & 35 & 26.7 & 96 & 73.3 & 131 \\
\hline NP-led Clinic & 30 & 96.8 & 1 & 3.2 & 31 \\
\hline Physician Office & 2 & 25.0 & 6 & 75.0 & 8 \\
\hline Walk-in Clinic & 1 & 25.0 & 3 & 75.0 & 4 \\
\hline $\begin{array}{l}\text { Specialty PHC } \\
\text { Clinic }\end{array}$ & 1 & 16.7 & 5 & 83.3 & 6 \\
\hline $\begin{array}{l}\text { Total } \\
\text { Missing }\end{array}$ & $\begin{array}{c}140 \\
1\end{array}$ & 49.6 & $\begin{array}{c}142 \\
0\end{array}$ & 50.4 & $\begin{array}{l}282 \\
283\end{array}$ \\
\hline
\end{tabular}




\section{Bivariate Relationships Between Factors and NP Patient Panel Size}

To answer the primary research question and the first secondary research question, other inferential statistical tests were used to examine the relationship between NP patient panel size and select patient, NP, and organizational factors. The factors used in these analyses were selected if there was sufficient variability in their respective measures. NPs with a patient panel were the focus for the rest of the statistical analysis. Scatterplots were used to confirm variability and to ensure no violation of the assumptions of normality, linearity, and homoscedasticity were present.

Patient factors. Patient factors that might influence panel size included age; gender; health status; socioeconomic status; the patient being new to the clinic, and/or to the NP; and same-day or unscheduled patient visits. Of these factors, health status and same-day patient visits had some variability in the responses and their relationship with NP patient panel size was examined using the Pearson's correlation coefficient.

Table 7 reports the Pearson's correlation coefficients for patient health status and sameday patient visits in relation to NP patient panel size. Patient health status was operationalized as appointment times for various health conditions and the percentage of patients the NP cared for with various health conditions. Longer appointment times due to certain health conditions were associated with smaller NP patient panel size; specifically, moderate correlations were found for palliative care and multi-morbidity appointment times and NP patient panel size (DV), indicating that time with these complex patients may negatively impact NP patient panel size resulting in smaller patient panel sizes.

In contrast, a weak, negative correlation was found for percentage of acute conditions, indicating that a high percentage of patients in a panel with acute conditions was associated with 
smaller NP patient panel sizes. A weak, positive correlation was found for percentage of chronic conditions, indicating that having a high percentage of patients with chronic conditions was associated with having larger NP patient panel size. The correlation coefficient between the percentage of same-day patient visits a NP sees per day and NP patient panel size was weak and not significant. 
Table 7

Patient Factors and NP Patient Panel Size Correlation

\begin{tabular}{|c|c|c|c|}
\hline Variable & $n=135$ & $\begin{array}{l}\text { NP Patient Panel Size: } \\
\text { Pearson's } r\end{array}$ & $\begin{array}{l}\text { Strength of } \\
\text { Relationship }\end{array}$ \\
\hline \multicolumn{4}{|l|}{ Patients in panel with (\%) } \\
\hline Acute conditions & 134 & $-.18^{*}$ & Weak \\
\hline Chronic conditions & 134 & $.25 * *$ & Weak \\
\hline Multi-morbidities & 134 & -.05 & Weak \\
\hline Palliative conditions & 134 & .06 & Weak \\
\hline \multicolumn{4}{|l|}{$\begin{array}{l}\text { Health status appointment } \\
\text { time (minutes) }\end{array}$} \\
\hline Acute condition & 135 & $-.20 *$ & Weak \\
\hline Single chronic condition & 135 & $-.29 * *$ & Weak \\
\hline Co-morbidity ${ }^{\mathrm{a}}$ & 135 & $-.17^{*}$ & Weak \\
\hline Multi-morbidity ${ }^{\mathrm{b}}$ & 135 & $-.30 * *$ & Moderate \\
\hline Palliative condition & 99 & $-.30 * *$ & Moderate \\
\hline Mental health & 135 & $-.19 *$ & Weak \\
\hline $\begin{array}{r}\text { Mental health \& chronic } \\
\text { illness }\end{array}$ & 135 & -.16 & Weak \\
\hline $\begin{array}{l}\text { Same-day patient } \\
\text { appointments }(\%)\end{array}$ & 135 & -.15 & Weak \\
\hline \multicolumn{4}{|c|}{$\begin{array}{l}\text { Note. Cohen's (1988) guidelines for } r \text { : a weak relationship is } \\
\text { strong relationship is }>.50 \text {. } \\
\text { a Co-morbidity is defined as having } 2 \text { chronic conditions } \\
{ }^{b} \text { Multi-morbidity is defined as having } \geq 3 \text { chronic conditions } \\
{ }^{*} p<.05 \text { two tailed. }{ }^{* *} p<.001 \text { two tailed. }\end{array}$} \\
\hline
\end{tabular}


NP factors. NP factors that might influence NP patient panel size included years of NP experience in total and in current practice setting, level of education, prior nursing experience, employment status (hours worked per week), and level of role clarity. Factors included for further analysis were years of NP experience (in total and in current practice setting) and employment status, these were ratio level variables and had enough variability within their means and ranges to use Pearson's ' $r$ '.

Table 8 reports the Pearson's correlation coefficients for NP years of experience and employment status in relation to NP patient panel size. NP years of experience in total and working in current practice setting had no significant relationships with NP patient panel size. The number of scheduled hours per week operationalized employment status and was examined in relation to NP patient panel size. NP employment status had a moderate, positive correlation with NP patient panel size; as NPs work more hours per week, their patient panel size increases as well. 
Table 8

NP Factors and NP Patient Panel Size Correlation

\begin{tabular}{|c|c|c|c|}
\hline Variable & $n=135$ & $\begin{array}{c}\text { NP Patient Panel Size: } \\
\text { Pearson's } r\end{array}$ & $\begin{array}{l}\text { Strength of } \\
\text { Relationship }\end{array}$ \\
\hline \multicolumn{4}{|l|}{ Years of experience } \\
\hline In total as a NP & 134 & .15 & Weak \\
\hline $\begin{array}{r}\text { In current practice } \\
\text { setting }\end{array}$ & 135 & .15 & Weak \\
\hline \multicolumn{4}{|l|}{ Employment status } \\
\hline $\begin{array}{r}\text { Hours worked per } \\
\text { week }\end{array}$ & 135 & $.38 * *$ & Moderate \\
\hline
\end{tabular}

Note. Cohen's (1988) guidelines for $r$ : a weak relationship is .00 to .29 , a moderate relationship is .30 to .49 , and a strong relationship is $>.50$.

** $p<.001$ two tailed. 
NP level of education was also included, as it was found to have enough variability. However, it was measured at an ordinal level. Level of education was collapsed into two groups, undergraduate (diploma/baccalaureate) and graduate (master's/doctorate), due to the small number of respondents in the diploma and doctorate categories. Therefore, an independent samples $t$-test was used to compare NP patient panel size based on NP level of education. No difference was found in NP patient panel size between undergraduate $(M=573.80, S D=218.35)$ and graduate $(M=461.69, S D=213.16) ; t(133)=1.67, \mathrm{p}=.10$, two tailed $)$ prepared NPs. The magnitude of the differences in the means (mean difference $=62.11,95 \%$ CI [-11.41 to 135.62]) was small (eta squared $=.02 ;$ Cohen, 1988).

Organizational factors. Organizational factors included time spent in direct care activities, time spent in indirect care activities, personnel support, practice model, practice size, practice location, NP autonomy, interdisciplinary team collaboration, NP-physician collaboration, and technology support. Factors included in analysis were: time spent doing home visits (including travel time), time spent in indirect care activities, number of exam rooms, and PHC practice model. These variables were chosen because all their frequencies, distributions, means, and ranges showed enough variability that a potential relationship could be tested with NP patient panel size. Time spent doing home visits, time in indirect care activities, and number of exam rooms were measured on a ratio level; therefore, Pearson's ' $r$ ' was used. The association between NP patient panel size and practice model was tested using ANOVA. Practice model was a categorical IV with five groups, thus ANOVA was appropriate.

Table 9 reports the Pearson's correlation coefficients between NP patient panel size and number of exam rooms, hours per week spent completing home visits, and time in indirect care activities as all are ratio level factors. Number of exam rooms, time completing home visits and 
travel time, and time spent in indirect care activities all had weak, positive, but non-significant correlations, with NP patient panel size. 
Table 9

Organizational Factors and NP Patient Panel Size Correlation

\begin{tabular}{|c|c|c|c|}
\hline Variable & $n=135$ & $\begin{array}{l}\text { NP Patient Panel Size: } \\
\text { Pearson's } r\end{array}$ & $\begin{array}{l}\text { Strength of } \\
\text { Relationship }\end{array}$ \\
\hline $\begin{array}{r}\begin{array}{r}\text { Number of exam } \\
\text { rooms }\end{array} \\
\end{array}$ & 135 & .16 & Weak \\
\hline \multicolumn{4}{|l|}{$\begin{array}{l}\text { Time spent in direct } \\
\text { care activities (hours } \\
\text { per week) }\end{array}$} \\
\hline Home visits & 118 & .02 & Weak \\
\hline $\begin{array}{r}\text { Travelling between } \\
\text { sites }\end{array}$ & 100 & -.11 & Weak \\
\hline $\begin{array}{l}\text { Time spent in indirect } \\
\text { care activities (times } \\
\text { completed per week) }\end{array}$ & 133 & .07 & Weak \\
\hline
\end{tabular}


The type of PHC practice model as illustrated in Table 6 was further analyzed using ANOVA. The ANOVA test was used to explore the relationship between the PHC practice model and NP patient panel size. Participants were divided into five groups according to clinic model: AHAC, CHC, FHT, NPLC, and Other. A difference was found between the groups, $F(4,129)=5.4, p=.00$. The effect size $($ eta squared $=.14)$ indicated a large effect size (Cohen, 1988). Post-hoc comparisons using the Tukey HSD test indicated that the mean NP patient panel size for NPLCs $(M=607.97, S D=197.06)$ was significantly larger than that found in both AHACs $(M=210.0, S D=143.99)$ and FHTs $(M=419.14, S D=218.13)$. The mean panel sizes for FHTs, CHCs $(M=504.67, S D=133.91)$, AHACs, and Other were not statistically significantly different from each other. Figure 2 presents the NP patient panel size by PHC practice model.

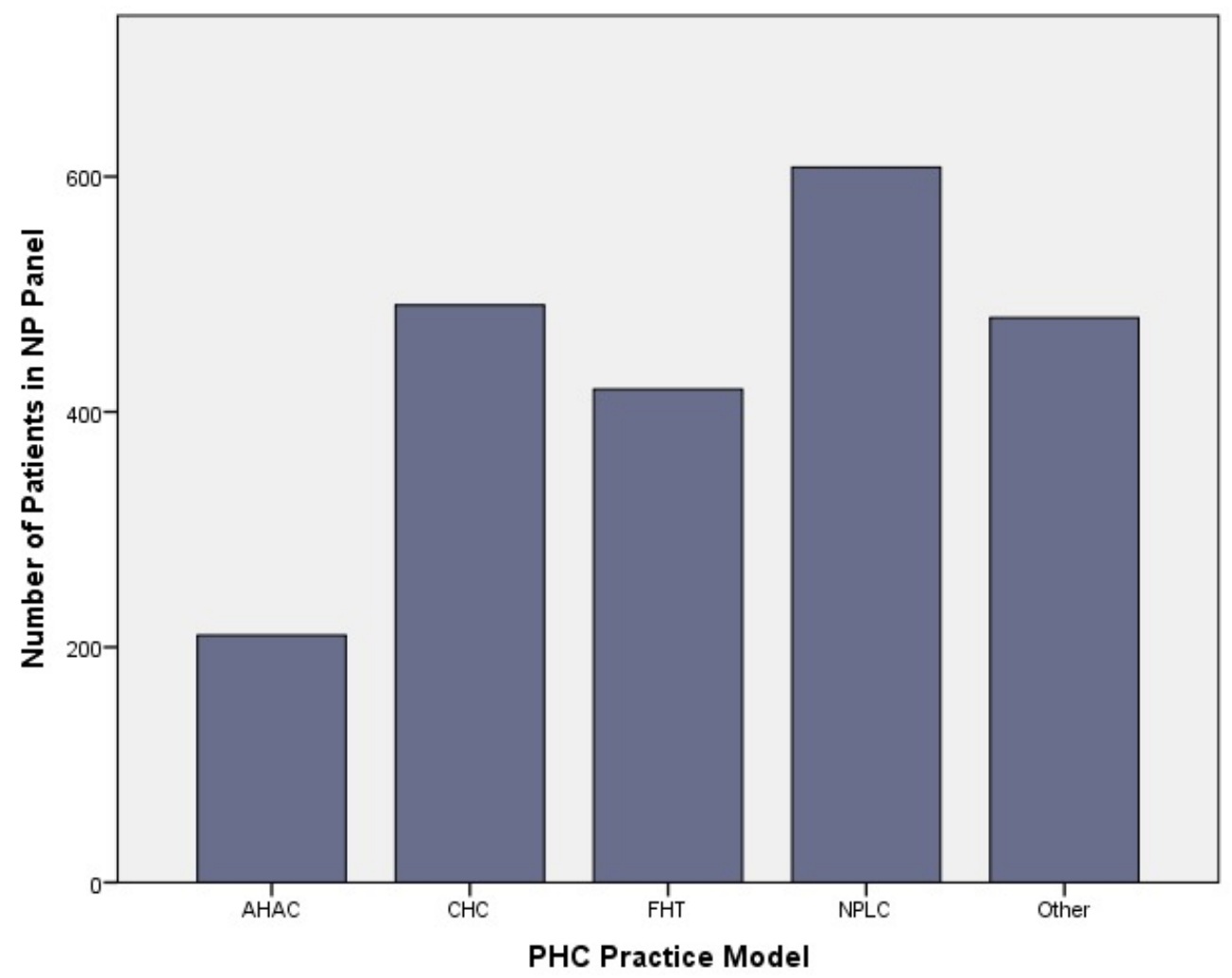

Figure 2. NP Patient Panel Size by PHC Practice Model 


\section{Summary of Findings}

In general, there were approximately even groups of NPs with and without their own patient panel. These two groups differed in employment status and current practice setting depending on whether they had their own patient panel or not. Patient factors largely reported by NPs, whether they had a patient panel or not, were that they saw an all-ages group patient population, mostly females, mainly low-income earners, and ample chronic and multi-morbid conditions. NP respondents mostly had graduate-level education with a wide range of prior RN experience, nearly 10 years of total NP experience, and six years of experience in their current practice setting. Lastly, most NPs practiced within a city-located FHT or CHC with access to approximately one exam room, worked with a variety of healthcare team members, and indicated satisfaction with autonomy and their relationship with the physician(s).

Furthermore, findings from this study demonstrated that higher percentages of certain health conditions (e.g., acute conditions) and/or longer appointment time for multi-morbid and palliative care conditions were associated with smaller NP patient panel size. As well, NPs who worked more hours per week had larger patient panels. Lastly, the type of PHC practice model was related to NP patient panel size, which was largest in NPLCs. 


\section{Chapter 5: Discussion}

At the beginning of this chapter, the representativeness of the sample is described. Key findings regarding NP patient panel size, and each of the patient, NP, and organizational factors are summarized. Implications, strengths, and limitations of this study are then discussed.

\section{Representativeness of the Sample}

The total sample sociodemographic characteristics were compared to the sociodemographic profile of NPs in Ontario using the CNO $(2014 ; 2015)$ documents to assess the representativeness of the sample. The CNO provides demographic data for all NPs regardless of setting. Therefore, the available sociodemographic data for NPs in general were used. CNO (2014) reported that the average age of NPs in Ontario was 44.6 years. The mean age of all NPs who participated in this study was 46.6 years and 47.5 years for those NPs with their own patient panel, indicating the study sample is slightly older than NPs in Ontario as reported by CNO. Furthermore, CNO (2014) reported that $6.1 \%$ of NPs were male and the remaining $93.9 \%$ were female. In this study, $6.7 \%$ were male and $93.3 \%$ were female of the total sample and very similarly $6.3 \%$ were male and $93.7 \%$ were female for NPs with their own patient panel, indicating the study sample was similar in proportion of males to females for NPs in Ontario. CNO (2015) reported that in Ontario $81.5 \%$ of NPs were employed full-time, $16 \%$ part-time, and $2.6 \%$ were casual. In the present study, $68.2 \%$ of the NPs were employed full-time, $29.7 \%$ parttime, and $2.1 \%$ casual; $71.6 \%$ of the NPs with their own patient panels were employed full-time, 19.8\% part-time, and none casual, indicating that the overall study sample worked full-time slightly less and part-time slightly more in comparison to Ontario NPs. The NPs with patient panels, however, were similar in comparison to the overall Ontario NP population. 
CNO $(2014 ; 2015)$ documents did not report NP levels of education; however, CNO (2015) reported the NP specialties with $18.7 \%$ registered in adult, $8 \%$ in paediatrics, and $73.3 \%$ in PHC. In the study sample, 3.2\% were adult, $98.2 \%$ were PHC, and none were registered in paediatrics; these proportions were similar for NPs with patient panels. The difference between the study sample and Ontario NPs may be due to the fact that the focus of the study was on NPs working in PHC settings where NPs see patients across the lifespan, thus it makes sense that NPs are more likely to be registered in the PHC category.

Although sociodemographic characteristic data from Ontario were not available specifically for NP populations in PHC, and the sample represented only $24 \%$ of NPs working in PHC settings based on CNO (2014) membership statistics, the study sample was fairly representative of the Ontario NP population. Study respondents were from broad geographical regions of Ontario and worked in all PHC delivery models, which improves the generalizability of the findings to all NPs working in PHC settings in Ontario.

\section{NP Patient Panel Size}

This study is the first to examine NP patient panel size in Ontario. The MOHLTC has the expectation that NPs working in NPLCs will build a patient panel size of 800 patients (DiCenso et al., 2010); however, other PHC practice model expectations are not specified, thus overall NP patient panel sizes were unknown prior to the present study. This is similar to physician patient panel size, as there is no standard physician patient panel size number and physician patient panels are determined by contextual factors based on the practice setting (CFCP, 2012). The results provided new insight into what NP patient panel size looks like in Ontario PHC settings. About half of the 283 NPs reported having their own patient panel with an average of 502 patients in the panel and 142 NPs did not have their own patient panel. This finding suggests that 
the context of the practice setting and expected panel size varies between practices. Additionally, 92 of the 142 NPs who did not have their own panels indicated that they shared a patient panel with one or more healthcare providers, which provides further evidence that NP patient panel size is operationalized differently across practice models. These contextual differences are highlighted by the finding that NPs who worked at NPLCs and CHCs were more likely to carry their own patient panel than those in FHTs and AHACs. This finding is not entirely surprising due to the differences in NP autonomy, responsibility, and interdisciplinary team focus across these PHC models (DiCenso et al., 2010; Thibeault, 2011). PHC practice model will be discussed in more detail below.

The sociodemographic characteristics of NPs with and without their own patient panel were also compared to understand potential differences among the sample. NP employment status by the number of scheduled hours worked per week and the NP's current practice setting were statistically significantly different, indicating that whether or not NPs have their own patient panel depends on the NPs' employment status and practice setting. These findings add to the literature, as the comparison of NPs with and without their own patient panel have not been published. As well, both findings are not surprising due to the literature that discusses the contextual nature of patient panel size (e.g., CFCP, 2012; Muldoon et al., 2012; Rayner, 2014).

Furthermore, based on questionnaire responses (e.g., respondents notes and question marks written on the questionnaire), some NPs may not have completely understood the term "patient panel size" despite the description in the information letter. The term "patient panel size" only began to appear in the literature in 2012 for Ontario physicians (CFPC, 2012; Muldoon et al., 2012) and has not been widely used for NPs. The lack of understanding of this term may have affected the answers on the questionnaire, as some NPs may have incorrectly 
indicated they did or did not carry a patient panel and as well did not know or provide the actual number of patients in their panel. This potential confusion may have resulted in an underreporting of the number of NPs with their own patient panel. This possible misunderstanding due to the novelty of NP patient panel size in PHC was considered when interpreting findings.

\section{Patient Factors}

There were many patient factors identified within the available literature as potentially influencing NP patient panel size; however, in the present study, only descriptive data could be reported for most of these factors. It was hypothesized that older patient age, female gender, and lower socioeconomic status would require more NP time and ultimately decrease NP patient panel size, but the findings of the present study indicated that the majority (78\%) of NPs with a patient panel reported a patient population that was comprised of all ages, rather than the trend most often described in the literature of mainly treating older adults (Koren et al., 2010; Mian et al., 2012; Sangster-Gormley et al., 2012; Sloan et al., 2006; Rayner, 2014; Roots \& MacDonald, 2014). NP participants with a patient panel also reported that although they treat a higher proportion of female patients, the appointment time did not vary by gender, with an average of approximately 30 minutes. However, it is not known if the female patients were more likely to have appointments more frequently than male patients, as well there was insufficient data on transgender appointment time. Lastly, although many NPs with their own panel $(n=75 ; 53 \%)$ reported treating mostly low-income patients, a somewhat smaller proportion $(n=43 ; 30 \%)$ reported treating a comparable number of patients of different income levels. The existing literature has largely been from a physician patient panel size perspective; therefore, perhaps these differences between the literature and the present study's findings indicate a difference in 
practice patterns of NPs with a patient panel, such as NPs completing more walk-in and sameday patient visits where they see a wide variety of patients and see more people of different ages and incomes, for example. These differences may also be due to the literature being largely from other countries, provinces, and jurisdictions, again highlighting contextual differences. The hypothesis that older patient age, female gender, and lower socioeconomic status negatively influence NP patient panel size was not supported.

Furthermore, NPs ranked patient health status as having the most impact on their patient panel size, which has consistently been reported in the literature as impacting NP time and resources (Dahrouge et al., 2014; Glazier et al., 2012; Muldoon et al., 2012; Potts et al., 2011; Sangster-Gormley et al., 2012; Watts et al., 2009; Way et al., 2001; VHA 2009, 2014). The importance of patient health status on NP patient panel size was supported by the relationship observed between health conditions and NP patient panel size. Specifically, seeing a higher percentage of patients with acute conditions was associated with a smaller NP patient panel size. This finding may represent the large portion of the respondents who indicated that acute conditions are often accompanied by chronic and/or multi-morbidities; therefore, a typical acute condition may take longer to address.

In contrast, seeing a higher percentage of patients with chronic conditions was associated with having a larger NP patient panel size. This was an unexpected finding, as the literature indicates that having patients with a large number of chronic conditions leads to decreased patient panel sizes. Those NPs who work in NPLCs have a larger patient panel size than the other models, so it may be that they also have a relatively larger proportion of patients with chronic conditions; while this study did not address this level of analysis, it is an important area for future research. The percentage of patients with multi-morbidities was not related to NP 
patient panel size, which was another unexpected finding. Chronic conditions are often accompanied by multi-morbidities, leading to longer appointment times to address multiple issues and provide increased teaching and counseling. However, it is likely that NPs grouped chronic and multi-morbid conditions together with acute conditions, and indicated that they often all occur together in a large majority of their patient population. Therefore, this potential grouping may have been related to the lack of definitions for each of the categories (i.e., acute, chronic, multi-morbidities). Nevertheless, all of these findings provide a better understanding of the health status of the patient population NPs treat.

Smaller patient panel sizes were associated with longer appointment times across a number of conditions: acute, single chronic, co-morbidity, multi-morbidity, palliative care, and mental health (see Table 7). The strongest relationships were with multi-morbidity and palliative care for appointment time. This finding is consistent with the literature in that these patients are more complex and take more of the NP's time, which impacts NP patient panel size (Dahrouge et al., 2014; Glazier et al., 2012; Muldoon et al., 2012; Potts et al., 2011; Rayner, 2014; SangsterGormley et al., 2012; Watts et al., 2009; Way et al., 2001; VHA 2009, 2014) and supports the hypothesis set out in Chapter 2 that patients who have multiple chronic diseases decrease NP patient panel size, as these patients require longer consultation times and more organization of resources.

The finding that multi-morbidity and palliative appointment times were associated with NP patient panel size, whereas the percentage of patients with multi-morbidities and palliative conditions were not, suggests that appointment time may be a stronger indicator of NP patient panel size than the patient's identified condition/diagnosis. The finding that appointment time may be a stronger indicator of patient panel size highlights that each patient needs to be assessed 
individually and a system should be used to adjust the panel size, such as the SAMI score. A group of patients seen by a NP may have chronic and/or multi-morbid conditions; however, may be well managed and thus does not necessarily mean they require more time. The concept of appointment time and understanding what is influencing the requirement for a longer appointment is important and requires further examination.

No relationship was found between same-day patient appointments and NP patient panel size. Based on the literature, same-day patient appointments were expected to impact NP patient panel size because these patients were potentially unknown to the NP requiring more time to complete an initial health history (Dahrouge et al., 2014; Hing et al., 2011; Glazier et al., 2012). However, NPs in the present study reported that same-day appointments were mostly patients they knew and/or had treated. This suggests that the familiarity of a patient to the NP may be more important than whether or not a patient appointment is scheduled in advance versus sameday. Transient patients or patients that move between PHC practices and providers were not specifically examined as a factor; however, may also be a part of same-day patient appointments adding another layer of complexity to this factor.

\section{NP Factors}

Based on the available literature, several NP factors were included in the present study. Due to issues with response variance, many factors could only be analyzed descriptively. Limited literature was found regarding the influence on panel size of prior RN experience before becoming a NP that made forming a hypothesis about this factor difficult; this relationship could not tested in the present study due to interrelating categories and lack of variability. However, $72 \%$ of NPs with their own patient panel had previous clinical experience from either hospital settings and/or community-based settings, the remaining NPs had experience in roles such as 
administration and education. With the majority having clinical backgrounds may suggest that a clinical nursing background prior to entering NP practice may provide a solid basis in nursing, including an understanding of autonomy and responsibility (Martin-Misener et al., 2010; Waszynski et al., 2000). Furthermore, NPs reported an excellent or good understanding of their NP role. With clinical nursing backgrounds and a strong understanding of their role, the NPs in this study were, on average, well prepared NPs. Despite this preparation, only half reported that they carried their own patient panel. This finding may be because there was potential underreporting of panel size due to lack of understanding among NPs of the term "patient panel size". As well, although the average NP respondent in the present study was well prepared, approximately $30 \%$ of the sample had less than three years of prior RN experience. Prior RN experience and NP role clarity may have a relationship with NP patient panel size; however, these associations require further exploration.

Based on the evidence from the literature it was hypothesized that novice NPs (less than five years of experience) were likely assigned smaller patient panel sizes due to inexperience in their role (Dierick-van Daele et al., 2009; Dierick-van Daele et al., 2011; Johnson, 2005; Venning et al., 2000; VHA, 2009). However, no relationship was found between years of experience (in total or in current practice setting) and NP patient panel size in the present study. It is possible that there is a relationship, but because the majority of NPs who participated in this study had a strong understanding of their role, a clinical nursing background, and were highly experienced, this relationship was not detected; therefore, the hypothesis that novice NPs were more likely to be assigned smaller patient panel sizes due to inexperience and their need for longer times to complete assessments was not supported by the present study's findings. NP level of education also had no relationship with NP patient panel size, the small effect size 
suggests that level of education may not lead to a meaningful increase in NP patient panel size. Thus, NP level of education may be a less important determinant of NP patient panel size.

In contrast, NP employment status, operationalized by the number of hours scheduled per week, had a moderate relationship with NP patient panel size. This association suggests that the more hours a NP worked, the larger their patient panel size. This finding is consistent with the literature in that the more hours a NP works, the more familiar they are with the patient population, and therefore the faster they can see patients (Donelan et al., 2013; Ortiz et al., 2010). Additionally, more hours worked logically translates to the potential to see more patients.

\section{Organizational Factors}

Lastly, several organizational factors were tested in the present study based on the available literature, but many could only be analyzed descriptively. The consensus in the literature was that NPs likely spend more time travelling between clinic sites than other healthcare providers (Buerhaus et al., 2015; Koren et al., 2010; Martin, 2000; Huang et al., 2004), but the majority of NPs $(n=210 ; 74 \%)$ in this study indicated they do not work between sites. How this travel compares to other providers was not investigated. The finding that the majority of the NP participants do not travel between clinic sites may be due to the fact that most of the respondents were practicing at a FHT or CHC within a city $(n=172 ; 60.8 \%)$. These clinics typically have abundant resources on site (Muldoon et al., 2013). As well, the literature was largely from other countries and provinces where NP practice patterns may be different from NPs in Ontario.

Descriptive findings highlighted that almost all NP participants frequently used EMR systems (more than four times per week) as part of their patient care. This finding adds to the literature on technology use and highlights the number of times per week NPs spend using EMR 
systems, which was unknown prior to this study due to the lack of literature on technology use. In addition, $74 \%$ of NPs indicated that they were responsible for cleaning exam rooms between patients, which impacts their overall time to see patients. Based on the literature, this NP cleaning responsibility is not surprising and has been found in other studies (e.g., Abood, 2005; Poghsyan et al., 2015; Rayner, 2014). These findings may provide further knowledge of NP time and activities.

The majority of NPs indicated that they were "Satisfied" or "Somewhat satisfied," with regard to all aspects of interdisciplinary team functioning, physician collaboration, and autonomy. Given the literature regarding NP dissatisfaction with these factors, this was an unexpected finding (Abood, 2005; van Soeren et al., 2009). This satisfaction suggests that the NPs who participated in this study may be more supported in their roles than the overall NP population and/or the NP role has become more established within Ontario PHC settings since the above published literature. Although the majority of NPs indicated that they were "Satisfied" or "Somewhat satisfied" on all three factors, further research is needed to identify the number and type of interdisciplinary staff and their role interaction with NPs to understand how this may influence NP patient panel size. The number of staff at each site was not captured in this study, which could have shown whether these NPs were more or less supported than the overall NP population. As well, during the period of this study, remuneration mechanisms changed so that NPs could refer directly to physician specialists (Health Services Branch, MOHLTC, 2015). This change may have also contributed to achieving higher team functioning satisfaction scores, due to NPs feeling a sense of increased autonomy within the healthcare team.

NP respondents ranked the time they spend in direct care activities as the most important influence on their patient panel size. This finding is consistent with reports of others that the time 
NPs spend in direct care activities (e.g., counseling) impacts NPs' overall available time to see an increased number of patients (Dahrouge et al., 2014; Koren et al., 2010). In addition to the impact of appointment times for certain health conditions on NP time, the amount of time spent in home visits was examined in this study where no relationship was found. Perhaps the time and types of direct care activities mandated by the patient needs and/or NP's organization does influence their patient panel size. However, the present study was unable to detect this potential relationship because few NPs indicated completing direct care activities such as shelter visits or long-term care visits. More research is needed around this factor, as time spent in shelter visits, long-term care visits, etc. was not captured. On the other hand, the finding that few NPs in this study indicated completing these activities suggests that these activities are not routinely part of most NPs' role. This context requires further investigation to explore the impact of external site visits, such as home visits and shelter visits on NP patient panel size.

Furthermore, despite the literature indicating the strong influence of the number of exam rooms on patient panel size (VHA 2009, 2014), the number of exam rooms was not associated with NP patient panel size in the present study. These NPs with a patient panel indicated they had access to a mean of 1.4 exam rooms. Others have reported or argued that having a greater number of exam rooms meant more patients could be seen and larger patient panels could be supported (Dahrouge et al., 2014; DiCenso et al., 2010; Duck et al., 2001; Hayes, 2007; Liu et al., 2014; Muldoon et al., 2012; Rayner, 2014; Sloan et al., 2006; VHA 2009, 2014). The VHA $(2009,2014)$ recommended three exam or consult rooms per PCP and noted that teaching students and other learners would require additional clinic rooms. The VHA $(2009,2014)$ also recommended specific support staff for an NP that was not explored in the present study. It is not known how the combination of an increased number and type of support staff and an increased 
number of exam rooms may influence NP patient panel size in Ontario PHC settings. However, this was a US study that included NPs, as well as other primary care providers. Nevertheless, the finding that the number of exam rooms was not associated with NP patient panel size in the present study could have been due to the fact that the majority of the respondents worked in FHTs and CHCs, where they typically have more resources, and the number of exam rooms may have been less of a factor for these NPs. There also is the potential that NPs misunderstood this particular question, potentially under-representing or over-representing the number of exam rooms they use on a daily basis and thus affecting the results. Overall, the hypothesis that NPs who work in large, urban practices with more support staff and increased autonomy may have larger patient panel sizes was not supported in the present study.

Time spent in indirect care activities was also not significantly related to NP patient panel size. This was an unexpected finding, as the literature suggested that NPs were very involved on a weekly basis with activities such as community development, administration, and health service planning (Koren et al., 2010; Martin-Misener et al., 2010; Sangster-Gormley et al., 2012; Thibeault, 2011). This finding could be due to NPs underreporting their time in these activities and/or the fact that the literature was from mainly an international and physician perspective representing potentially different practice patterns than Ontario NPs.

In contrast, the type of PHC practice model was significantly associated with NP patient panel size with a large effect size suggesting that the type of PHC practice model has a meaningful influence on NP patient panel size. Differences were found between the different PHC practice models and NP patient panel size. Specifically, NPLCs had much larger patient panel sizes than those NPs who worked in AHACs or FHTs. Furthermore, NPs who worked at NPLCs and CHCs were more likely to carry their own patient panel than those NPs working in 
other clinic models. NPLCs typically do not have a physician on site most days of the week (DiCenso et al., 2010); therefore, the finding that NPs working in NPLCs were more likely to carry their own patient panels is consistent with the literature. It also makes sense that NPs were more likely to carry their own patient panel at $\mathrm{CHCs}$, where there is a stronger collaborative interdisciplinary team-based model and where physicians are typically remunerated through a salary model (Muldoon et al., 2013). In comparison, FHTs are typically well resourced and NPs work directly with a team of physicians who may be in supervisory roles and/or are reimbursed on a rostered/blended model per patient. The FHT model may make it less likely for NPs to carry their own patient panels, and instead share patients (Muldoon et al., 2013). Shared patient panel models were beyond the scope of this study and thus were not explored in further detail. However, NPs were less likely to have a patient panel if they worked in models in which physicians were more likely to be in a position of authority over the NP and/or with physicians who relied on fee-for service or per-patient remuneration (e.g., FHTs, physician offices, walk-in clinics, specialty PHC clinics). Walk-in clinics, physician offices and specialty PHC clinics were grouped as the "Other" category in the results section.

\section{Implications}

The data obtained provides an understanding of the patient, NP, and organizational factors from the NP perspective that inform NP roles and activities, a key component of NP patient panel size. Implications of the findings are discussed for nursing research, administrators, policy decision makers, and NP education and practice.

Nursing research. Due to both the limited variance of NP patient panel size and some of the IVs, and the finding that only half the sample reported having a patient panel, the use of multiple regression analysis to predict the factors most important to NP patient panel size was 
precluded, even though the sample was sufficient to meet the power calculation for sample size. Not being able to complete multiple regression impeded findings such as, whether patient age or multi-morbidities, for example, had a greater influence on NP patient panel size, which would have provided valuable information to further develop the concept of NP patient panel size. Understanding why the multiple model regression was not possible for the present study informs future research designs around NP patient panel size. Researchers can use this study's findings to design different research approaches. For example, future research may take a more narrow approach and focus on specific factors such as PHC practice model because looking at each factor in a more detailed way may increase the potential to further explore NP patient panel size and the factors that influence quality patient care.

Research is also needed to further compare the types of NP patient panels within the different practice models by exploring the differences between the NPs who stated they had a patient panel versus those that shared a panel. It was beyond the scope of the present study to explore shared panels. Understanding the differences in practice patterns between these NPs working in different PHC settings would provide a more complete picture of the factors that influence NP patient panel size in Ontario. Additionally, following-up on the present study's findings with a qualitative study, such as interviewing NPs across the province who are working in different PHC models would shed light on the factors that influence NP patient panel size. Further qualitative information may help researchers understand how NPs recognize and interpret the term "patient panel size", and may also help to gain a clearer comprehension of the factors that influence NP patient panel size in Ontario.

Relationships were found between some of the factors identified in the literature and NP patient panel size, that is longer multi-morbidity and palliative care appointment time decreased 
NP patient panel size. These associations support the notion described in Chapter 1, that due to overlapping scopes of practice between NPs and physicians and similar practice environments, some of the factors that impact physicians' patient panel sizes also impact those of NPs' (Donald et al., 2010; Marchildon, 2005). Future research can continue to explore similarities and differences in factors associated with patient panel size between NPs and physicians working in PHC, to gain a clearer understanding of NP patient panels. Due to the number and complexity of potential influencing factors, a next step for future research would be to look at each factor in more detail using both qualitative and quantitative methods.

As well, components of the conceptual model, such as system factors and outcomes, were not investigated in this study but are likely important to understanding NP patient panel size and could be explored further in future research. Improving data by linking patients to the practice and having practices continually evaluated on a number of outcome factors including patient outcomes, patient and provider satisfaction, and quality of care processes would be a way to explore outcomes for NP patient panel size in the future.

Administrators. The present study improved knowledge about patient, NP, and organizational factors that might influence NP patient panel size in PHC settings in Ontario. Some aspects of NP practice patterns, role components, and activities were identified that administrators in various models of NP practice can focus on when considering the optimization of NP patient panel size. An example of a NP activity includes the frequent use of EMR systems. Retrieval of patient information and the time for documentation suggests to administrators that there is a need for continual reassessment and streamlining of these systems to ensure efficiency (Evans et al., 2010). Another example of a NP activity administrators can focus on when considering the optimization of NP patient panel size is home visits. In the present study, home 
visits were completed by only half of the NPs, which is an activity that could be increased in various practice models to increase access to patient care; however, should be considered when determining NP patient panel size. As well, understanding that multi-morbid and palliative patients require longer appointment times, due to increased patient needs and resources, highlights the need for administrators and their organizations to create sufficient appointment time and resources for these patients and to consider smaller panel size options for NPs who care for them. Smaller panels may allow complex patients to receive quality care and reduce other demands on the system related to possible improved outcomes. Understanding the length of time needed for complex patient care and its influence on NP patient panel size may also encourage or support administrators to implement a formal method of adjusting for patient complexity, such as SAMI, when determining panel size.

Policy makers. Policy makers can benefit from this research. For instance, it may provide them with a better understanding of some factors that impact NPs' patient panel size in PHC settings that could inform health workforce planning and better allocation of resources. By understanding that patient health status, NP employment status, and types of PHC practice model influence NP patient panel size, policy makers can be more aware of some key factors influencing NP patient panel size before developing relevant policies and can give further consideration to these specific factors.

Furthermore, this research highlights the highly contextual and complex nature of NP patient panel size and draws attention to the need for more research before concrete policy decisions can be made. The findings of the present research serve as a reminder for policy makers that patient panel size is not a one-size-fits-all solution and there are a number of contextual factors that may have an influence. Therefore, setting specific patient panel size goals, 
such as the expectation for NPs in NPLCs to maintain a patient panel of 800 might be an impractical expectation in Ontario PHC settings. Contextual differences within PHC models need to be taken into consideration, e.g., some FHTs serve primarily an older population with an increased number of multi-morbidities versus other FHTs that serve primarily young families with children (Glazier et al., 2012). No participants in this Ontario study indicated that they had the available supports and space recommended by the VHA (2014) of at least three support staff to one FTE PCP to maintain a certain panel size, three exam rooms per PCP. The contextual aspects of both NP practice within and across Ontario PHC practice models needs to be considered when making policy decisions that influence NP patient panel size. Knowledge and understanding of NP patient panel size across different practice models can better inform health workforce planning and decisions regarding NP workload, productivity, patient needs, and the number of patients NPs are expected to care for.

NP education. Gaining a more comprehensive understanding of NP patient panel size and its potential influencing factors provides new knowledge that NP educators can incorporate into their curriculum. This knowledge may provide graduating NPs with a clearer understanding of workload, patient needs, and expectations in PHC. New knowledge about the key factors that influence NP patient panel size may allow educators to incorporate focused education, and include such topics as complex patient care, mental health conditions, time management skills, and utilization of community resources. Teaching NP students about these specific concepts may improve their understanding and ability to take on potentially complex patient panels.

NP practice. The present study findings may make NPs more aware of where they are spending their time, where they can improve their own individual practice and time management, and may generate more discussion within practice settings regarding NP patient panel size to 
clearly articulate what their practice needs are moving forward. Furthermore, these findings may promote inter-professional practice and further collaboration with physicians due to identified complex patient care needs, as well as roles and activities of NPs, e.g., cleaning and preparing exam rooms between patient uses, that require more support.

\section{Strengths and Limitations}

One of the strengths of the present study was that it was guided by a conceptual model derived from a recent scoping review of the literature (Martin-Misener et al., 2015). In addition, readily available instruments through CIHI (2013) were used with questions adapted by a panel of experts and questions added from the available literature. Pilot testing of the questionnaire was completed with four NPs working in diverse PHC settings to reduce bias and increase validity to determine adequacy of the instrument to measure the DV and IVs. Furthermore, by using two sampling methods and two repeat reminder mailings an adequate sample size and response rate was obtained.

There were limitations to the present study. Due to the self-report nature of a survey design, there was the potential of response bias (e.g., misunderstanding survey questions and/or giving socially acceptable answers) (Grove et al., 2013). Pilot testing with four different NPs working in PHC helped reduce potential clarity issues contributing to NPs misunderstanding questions. As well, potential response bias, such as giving socially acceptable answers, was taken into consideration during data analysis and interpretation. Furthermore, because the assumptions of multiple regression were not met, the planned multiple regression analysis to answer secondary research questions 2,3 , and 4 could not be carried out. Lastly, NP patient panel size is a new concept within the PHC environment, which may have introduced the potential for NPs to not understand or be familiar with the concept to answer the questionnaire accurately; however, a 
working definition was provided in both recruitment material and the consent form. . A recommendation for future studies is to include the definition within the questionnaire to increase the likelihood that participants will read the definition. As well, due to its novelty, influencing factors may have been missed, as they have not yet been identified to be associated with NP patient panel size.

\section{Conclusion}

Overall, this study provided information about NP patient panel size and factors that may impact it in Ontario PHC settings. Higher percentages of certain health conditions and/or longer appointment time for multi-morbid and palliative care conditions, NPs who work more hours, and PHC practice model were all associated with NP patient panel size, indicating that these factors are important to consider when optimizing NP patient panel size. Findings regarding NP patient panel size also suggested implications for focused nursing research, NP education, and NP practice considerations. Administrators and policy makers can benefit from this research to create policies that consider the complexities of patient needs, NP factors, and organizational influences that impact NP patient panel size to benefit patients, NPs, the practice, and ultimately the broader health care system. 


\section{Appendices}

\section{Appendix A}

\section{Literature Review Search Terms}

\begin{tabular}{|l|l|}
\hline \multicolumn{1}{|c|}{ Topic } & \multicolumn{1}{c|}{ Search Terms } \\
\hline Nurse Practitioner & $\begin{array}{l}\text { Nurse practitioners, family nurse practitioners, primary care nurse practitioners, } \\
\text { advanced practice nurse, NP, education, entry to practice, NP experience }\end{array}$ \\
\hline Primary Care & $\begin{array}{l}\text { Primary health care, primary care, outpatient care, outpatient clinic, outpatient } \\
\text { service, ambulatory care, ambulatory care facilities, ambulatory clinic, walk-in } \\
\text { clinic, nursing station, community health services, community health nursing, } \\
\text { family, rural health, rural health services, rural health nursing, rural population, } \\
\text { rural, remote }\end{array}$ \\
\hline Workload & $\begin{array}{l}\text { Workload, caseload, benchmark, benchmarking, diagnosis-related groups, health } \\
\text { care manpower, health manpower, workforce planning, organization and } \\
\text { administration, management, administration, organizational efficiency, } \\
\text { productivity, organization and manpower, organizational decision making, } \\
\text { decision making, organizational model, personnel management, refusal to treat, } \\
\text { patient-centred care, health transition, hand off (patient safety), continuity of } \\
\text { patient care }\end{array}$ \\
\hline Patient panel, patient panel size, patient population, roster, case mix, patient mix \\
\hline
\end{tabular}




\section{Appendix B}

\section{Summary of Literature Examining Patient Factors}

\begin{tabular}{|c|c|c|c|c|c|c|c|}
\hline Source & Purpose & Design & Sample & Concepts & Instruments & Results & Comments \\
\hline $\begin{array}{l}\text { Bertakis, } \\
\text { Azari, } \\
\text { Helms, } \\
\text { Callahan, \& } \\
\text { Robbins, } \\
(2000)\end{array}$ & $\begin{array}{l}\text { Using patient } \\
\text { socio- } \\
\text { demographics } \\
\text { and health } \\
\text { status, to } \\
\text { investigate } \\
\text { gender } \\
\text { differences in } \\
\text { the use and costs } \\
\text { of healthcare } \\
\text { services }\end{array}$ & $\begin{array}{l}\text { Randomized } \\
\text { control trial }\end{array}$ & $\begin{array}{l}\text { New adult } \\
\text { patients }(n=509) \\
\text { were randomly } \\
\text { assigned to } \\
\text { primary care } \\
\text { providers at a } \\
\text { university } \\
\text { medical center } \\
\text { United States } \\
\text { (US) }\end{array}$ & Gender & $\begin{array}{l}\text { Pre/post study } \\
\text { interviews } \\
\text { Medical Outcomes } \\
\text { Study Short Form- } \\
36 \text { (SF-36) }\end{array}$ & $\begin{array}{l}\text { Women require } \\
\text { more healthcare } \\
\text { visits, longer } \\
\text { exams, present } \\
\text { with more } \\
\text { complex issues }\end{array}$ & $\begin{array}{l}\text { Study done in } \\
\text { the United } \\
\text { States (US), } \\
\text { may not be } \\
\text { representative } \\
\text { of Ontario NPs } \\
\text { Indicates } \\
\text { gender } \\
\text { differences } \\
\text { found in NP } \\
\text { literature }\end{array}$ \\
\hline $\begin{array}{l}\text { Buerhaus, } \\
\text { DesRoches, } \\
\text { Dittus, \& } \\
\text { Donelan, } \\
(2015)\end{array}$ & $\begin{array}{l}\text { The purpose of } \\
\text { this study was to } \\
\text { identify } \\
\text { demographic } \\
\text { and practice } \\
\text { characteristics of } \\
\text { PCNPs and to } \\
\text { compare these } \\
\text { characteristics } \\
\text { with primary } \\
\text { care physicians } \\
\text { (PCMDs) }\end{array}$ & $\begin{array}{l}\text { Cross- } \\
\text { sectional } \\
\text { survey }\end{array}$ & $\begin{array}{l}\text { From November } \\
23,2011, \text { to } \\
\text { April 9, 2012, } \\
\text { we conducted a } \\
\text { national postal } \\
\text { mail survey of } \\
972 \text { clinicians } \\
\text { (467 PCNPs and } \\
505 \text { PCMDs) } \\
\text { United States } \\
\text { (US) }\end{array}$ & $\begin{array}{l}\text { Socioeconomic } \\
\text { status }\end{array}$ & $\begin{array}{l}\text { Questionnaire } \\
\text { domains included } \\
\text { compensation and } \\
\text { billing practices; } \\
\text { characteristics of } \\
\text { patients treated; } \\
\text { PCNPs' use of } \\
\text { their own National } \\
\text { Provider } \\
\text { Identification } \\
\text { number to bill } \\
\text { services; how } \\
\text { PCNPs spend their } \\
\text { time; clinical and } \\
\text { nonclinical } \\
\text { activities } \\
\text { performed; and } \\
\text { whether PCNPs } \\
\text { have privileges to }\end{array}$ & $\begin{array}{l}\text { PCNPs are more } \\
\text { likely to treat } \\
\text { Medicaid } \\
\text { recipients and } \\
\text { other vulnerable } \\
\text { populations }\end{array}$ & $\begin{array}{l}\text { Study done in } \\
\text { the US, may } \\
\text { not be } \\
\text { representative } \\
\text { of Ontario NPs }\end{array}$ \\
\hline
\end{tabular}




\begin{tabular}{|c|c|c|c|c|c|c|c|}
\hline Source & Purpose & Design & Sample & Concepts & Instruments & Results & Comments \\
\hline & & & & & $\begin{array}{l}\text { admit, round on } \\
\text { (i.e., oversee the } \\
\text { care provided to) } \\
\text { patients, and write } \\
\text { orders } \\
\text { independently of } \\
\text { physicians. The } \\
\text { response rate was } \\
61.2 \% \text {. }\end{array}$ & & \\
\hline $\begin{array}{l}\text { Canadian } \\
\text { Womens } \\
\text { Health } \\
\text { Network, } \\
(2005)\end{array}$ & $\begin{array}{l}\text { Report } \\
\text { published to } \\
\text { produce } \\
\text { information } \\
\text { around PHC } \\
\text { reform in } \\
\text { Canada and why } \\
\text { it is particularly } \\
\text { important to } \\
\text { women }\end{array}$ & $\begin{array}{l}\text { Discussion } \\
\text { Report }\end{array}$ & $\begin{array}{l}\text { Canadian study- } \\
\text { national } \\
\text { perspective }\end{array}$ & Female gender & & $\begin{array}{l}\text { Women require } \\
\text { more frequent } \\
\text { visits, longer } \\
\text { exams, and } \\
\text { bring their } \\
\text { children to } \\
\text { appointments }\end{array}$ & $\begin{array}{l}\text { Not specific to } \\
\text { NP PHC } \\
\text { Included to } \\
\text { provide more } \\
\text { information } \\
\text { around female } \\
\text { gender health } \\
\text { needs in PHC }\end{array}$ \\
\hline $\begin{array}{l}\text { Dahrouge et } \\
\text { al. (2014) }\end{array}$ & $\begin{array}{l}\text { To describe the } \\
\text { models of } \\
\text { practice used by } \\
\text { nurse } \\
\text { practitioners } \\
\text { (NPs) and FPs in } \\
\text { community } \\
\text { health centres } \\
\text { (CHCs), and to } \\
\text { examine the } \\
\text { roles of NPs and } \\
\text { FPs in these } \\
\text { models. }\end{array}$ & $\begin{array}{l}\text { Cross- } \\
\text { sectional } \\
\text { survey }\end{array}$ & $\begin{array}{l}21 \mathrm{CHCs} \\
\text { A total of } 44849 \\
\text { patients, } 53 \text { full- } \\
\text { time equivalent } \\
\text { FPs, and } 41 \text { full- } \\
\text { time equivalent } \\
\text { NPs. } \\
\text { Ontario study }\end{array}$ & $\begin{array}{l}\text { Patient age and } \\
\text { gender } \\
\text { Socioeconomic } \\
\text { status } \\
\text { Same-day } \\
\text { patient visits }\end{array}$ & $\begin{array}{l}\text { Organizational } \\
\text { survey completed } \\
\text { by managers of the } \\
\text { CHC sites, as well } \\
\text { as administrative } \\
\text { data on patient } \\
\text { sociodemographic } \\
\text { characteristics and } \\
\text { encounter } \\
\text { activities }\end{array}$ & $\begin{array}{l}\text { Patients from } \\
\text { CHCs who } \\
\text { received care } \\
\text { from a NP } \\
\text { tended to be } \\
\text { younger, } \\
\text { female, } \\
\text { homeless, and } \\
\text { did not have a } \\
\text { postsecondary } \\
\text { education } \\
\text { NPs do more } \\
\text { walk-in visits } \\
\text { versus family } \\
\text { physicians }\end{array}$ & $\begin{array}{l}\text { Results } \\
\text { exclusive to } \\
\text { Ontario CHCs }\end{array}$ \\
\hline
\end{tabular}




\begin{tabular}{|c|c|c|c|c|c|c|c|}
\hline Source & Purpose & Design & Sample & Concepts & Instruments & Results & Comments \\
\hline $\begin{array}{l}\text { Deshefy- } \\
\text { Longhi, } \\
\text { Swartz, \& } \\
\text { Grey (2008) }\end{array}$ & $\begin{array}{l}\text { Characterize } \\
\text { NPs practice by } \\
\text { using reports of } \\
\text { patient } \\
\text { encounters to } \\
\text { more accurately } \\
\text { reflect practice } \\
\text { patterns than has } \\
\text { been previously } \\
\text { performed }\end{array}$ & $\begin{array}{l}\text { Cross- } \\
\text { sectional } \\
\text { survey }\end{array}$ & $\begin{array}{l}54 \text { NPs from } 45 \\
\text { different practice } \\
\text { sites (both acute } \\
\text { care and primary } \\
\text { care settings } \\
\text { within the } \\
\text { practice-based } \\
\text { research } \\
\text { networks) } \\
\text { More than 55\% } \\
\text { of NPs in sample } \\
\text { practices in } \\
\text { community- } \\
\text { based primary } \\
\text { care clinics, } \\
\text { private pediatric } \\
\text { and obstetrical } \\
\text { practices, and } \\
\text { home visits to } \\
\text { elderly patients } \\
\text { living in } \\
\text { facilities } \\
\text { United States } \\
\text { study }\end{array}$ & $\begin{array}{l}\text { Patient age, } \\
\text { gender, and } \\
\text { health status }\end{array}$ & $\begin{array}{l}\text { Two part survey } \\
\text { included } \\
\text { demographic form } \\
\text { and practice form }\end{array}$ & $\begin{array}{l}\text { Majority of } \\
\text { patients were } \\
\text { between } 14 \text { and } \\
64 \text { years of age } \\
\text { Patients more } \\
\text { frequently } \\
\text { female } \\
\text { NPs in PHC } \\
\text { spend } 45 \% \text { of } \\
\text { their patient } \\
\text { visits treating } \\
\text { acute illness and } \\
30 \% \text { of their } \\
\text { patient visits on } \\
\text { chronic illness }\end{array}$ & $\begin{array}{l}\text { Study done in } \\
\text { the US, may } \\
\text { not be } \\
\text { representative } \\
\text { of Ontario NPs }\end{array}$ \\
\hline $\begin{array}{l}\text { Dierick-van } \\
\text { Daele et al. } \\
(2010)\end{array}$ & $\begin{array}{l}\text { To estimate } \\
\text { costs of GP } \\
\text { versus NP } \\
\text { consultations } \\
\text { from practice } \\
\text { and societal } \\
\text { perspectives }\end{array}$ & $\begin{array}{l}\text { Randomized } \\
\text { control trial } \\
\text { (RCT) }\end{array}$ & $\begin{array}{l}\text { Patients were } \\
\text { randomly } \\
\text { allocated to GP } \\
\text { or NP } \\
\text { consultation } \\
\text { Netherland study }\end{array}$ & $\begin{array}{l}\text { Age and gender } \\
\text { of patients }\end{array}$ & $\begin{array}{l}\text { Chart reviews to } \\
\text { evaluate resource } \\
\text { use, follow-up } \\
\text { consultations, } \\
\text { length of } \\
\text { consultations, and } \\
\text { salary costs }\end{array}$ & $\begin{array}{l}\text { Increased } \\
\text { workload with } \\
\text { increasing age } \\
\text { of patients } \\
\text { Direct costs } \\
\text { lower for NP } \\
\text { consultations } \\
\text { NPs treat a } \\
\text { higher } \\
\text { proportion of }\end{array}$ & $\begin{array}{l}\text { Dutch study } \\
\text { Focused on NP } \\
\text { cost- } \\
\text { effectiveness, } \\
\text { but provided } \\
\text { relevant results } \\
\text { on types of } \\
\text { patients NPs } \\
\text { treat }\end{array}$ \\
\hline
\end{tabular}




\begin{tabular}{|c|c|c|c|c|c|c|c|}
\hline Source & Purpose & Design & Sample & Concepts & Instruments & Results & Comments \\
\hline & & & & & & female patients & \\
\hline $\begin{array}{l}\text { Donald et al. } \\
(2010)\end{array}$ & $\begin{array}{l}\text { To develop a } \\
\text { better } \\
\text { understanding of } \\
\text { advanced } \\
\text { practice nursing } \\
\text { roles, their } \\
\text { current use, and } \\
\text { the individual, } \\
\text { organizational } \\
\text { and health } \\
\text { system factors } \\
\text { that influence } \\
\text { their effective } \\
\text { development } \\
\text { and integration }\end{array}$ & $\begin{array}{l}\text { Literature } \\
\text { Review }\end{array}$ & $\begin{array}{l}468 \text { articles } \\
\text { Interviews ( } n= \\
62) \text { and focus } \\
\text { groups ( } n=4 \\
\text { with a total of } 19 \\
\text { NPs) } \\
\text { Ontario study }\end{array}$ & $\begin{array}{l}\text { Socioeconomic } \\
\text { status }\end{array}$ & $\begin{array}{l}\text { Literature review } \\
\text { and key informant } \\
\text { interviews }\end{array}$ & $\begin{array}{l}\text { Majority of } \\
\text { respondents } \\
\text { from a previous } \\
\text { survey on } \\
\text { Ontario } \\
\text { PHCNPs } \\
\text { reported } \\
\text { working with } \\
\text { marginalized } \\
\text { populations }\end{array}$ & $\begin{array}{l}\text { No focus on } \\
\text { impact of } \\
\text { socioeconomic } \\
\text { status on NP } \\
\text { patient panel } \\
\text { size }\end{array}$ \\
\hline $\begin{array}{l}\text { Duck, } \\
\text { DeLia, \& } \\
\text { Cantor } \\
(2001)\end{array}$ & $\begin{array}{l}\text { Use a survey of } \\
\text { free-standing } \\
\text { clinics and } \\
\text { hospital } \\
\text { outpatient } \\
\text { departments to } \\
\text { develop two } \\
\text { measures of } \\
\text { facility } \\
\text { productivity and } \\
\text { describe which } \\
\text { inputs and } \\
\text { facility } \\
\text { characteristics } \\
\text { are associated } \\
\text { with } \\
\text { productivity }\end{array}$ & $\begin{array}{l}\text { Cross- } \\
\text { sectional } \\
\text { survey }\end{array}$ & $\begin{array}{l}226 \text { hospitals-- } \\
\text { sponsored and } \\
\text { free-standing } \\
\text { ambulatory care } \\
\text { sites or the sites' } \\
\text { sponsoring } \\
\text { organizations in } \\
\text { New York City } \\
\text { in late } 1997 \\
\text { Target } \\
\text { population } \\
\text { within } 226 \\
\text { hospitals-- } \\
\text { physician } \\
\text { assistants, NPs, } \\
\text { certified nurse } \\
\text { midwives, } \\
\text { medical } \\
\text { residents, and }\end{array}$ & $\begin{array}{l}\text { Socioeconomic } \\
\text { status }\end{array}$ & $\begin{array}{l}1997 \text { New York } \\
\text { City Ambulatory } \\
\text { Care Provider } \\
\text { Survey } \\
\text { The survey } \\
\text { collected } \\
\text { information about } \\
\text { provider } \\
\text { characteristics and } \\
\text { auspices, scope } \\
\text { and volume of } \\
\text { services provided, } \\
\text { staffing, managed } \\
\text { care arrangements, } \\
\text { and payer mix }\end{array}$ & $\begin{array}{l}\text { Response rate of } \\
80 \% \\
\text { Lower } \\
\text { socioeconomic } \\
\text { status increases } \\
\text { provider } \\
\text { workload }\end{array}$ & $\begin{array}{l}\text { Study done in } \\
\text { the US, may } \\
\text { not be } \\
\text { representative } \\
\text { of Ontario NPs }\end{array}$ \\
\hline
\end{tabular}




\begin{tabular}{|c|c|c|c|c|c|c|c|}
\hline Source & Purpose & Design & Sample & Concepts & Instruments & Results & Comments \\
\hline & & & $\begin{array}{l}\text { nonresident } \\
\text { physicians } \\
\text { United States } \\
\text { study }\end{array}$ & & & & \\
\hline $\begin{array}{l}\text { Glazier, } \\
\text { Zagorski, \& } \\
\text { Rayner } \\
(2012)\end{array}$ & $\begin{array}{l}\text { Examined } \\
\text { patients/clients } \\
\text { enrolled in } \\
\text { CHCs, FHTs, } \\
\text { Family health } \\
\text { groups, family } \\
\text { health networks, } \\
\text { family health } \\
\text { organizations to } \\
\text { determine if } \\
\text { there is a } \\
\text { difference } \\
\text { between Ontario } \\
\text { PHC models and } \\
\text { how often their } \\
\text { patients/clients } \\
\text { go to the ED }\end{array}$ & $\begin{array}{l}\text { Secondary } \\
\text { data analysis }\end{array}$ & $\begin{array}{l}\text { All residents of } \\
\text { Ontario eligible } \\
\text { for health care in } \\
2008 / 09 \text { to } 2009 \text { - } \\
10 \text { with a } \\
\text { physician/NP } \\
\text { visit during this } \\
\text { time period and } \\
\text { alive on March } \\
31,2010 \text { were } \\
\text { included- } \\
11,896,508 \\
\text { residents } \\
\text { Ontario study }\end{array}$ & $\begin{array}{l}\text { Health status of } \\
\text { patient } \\
\text { Socioeconomic } \\
\text { status } \\
\text { Same-day } \\
\text { patient visits }\end{array}$ & $\begin{array}{l}\text { Electronic record } \\
\text { encounter for } \\
\text { CHCs and } \\
\text { routinely collected } \\
\text { health care } \\
\text { administrative data } \\
\text { were used }\end{array}$ & $\begin{array}{l}\text { Lower } \\
\text { socioeconomic } \\
\text { status increases } \\
\text { provider } \\
\text { workload } \\
\text { CHCs have } \\
\text { more } \\
\text { newcomers }\end{array}$ & $\begin{array}{l}\text { Focused on } \\
\text { physicians, } \\
\text { looked at NPs } \\
\text { as part of the } \\
\text { inter- } \\
\text { disciplinary } \\
\text { team } \\
\text { Data around } \\
\text { NPs focused on } \\
\text { NPs in CHCs } \\
\text { exclusively }\end{array}$ \\
\hline $\begin{array}{l}\text { Hing, } \\
\text { Hooker, \& } \\
\text { Ashman } \\
(2011)\end{array}$ & $\begin{array}{l}\text { Compared the } \\
\text { role of NPs, } \\
\text { PAs, nurse } \\
\text { midwives, and } \\
\text { physicians in } \\
\text { CHCs }\end{array}$ & $\begin{array}{l}\text { Cross- } \\
\text { sectional } \\
\text { survey }\end{array}$ & $\begin{array}{l}1434 \text { providers } \\
\text { and their visits } \\
\text { during 2006- } \\
2007 \\
\text { United States } \\
\text { study }\end{array}$ & $\begin{array}{l}\text { Patient gender } \\
\text { New patients }\end{array}$ & $\begin{array}{l}\text { National } \\
\text { ambulatory } \\
\text { medical care } \\
\text { survey }\end{array}$ & $\begin{array}{l}\text { NPs treat higher } \\
\text { percentage of } \\
\text { female patients } \\
\text { CHCs are more } \\
\text { likely to accept } \\
\text { new patients } \\
\text { versus office } \\
\text { based practices }\end{array}$ & $\begin{array}{l}\text { Survey done in } \\
\text { the US, may } \\
\text { not be } \\
\text { representative } \\
\text { of Ontario NPs }\end{array}$ \\
\hline $\begin{array}{l}\text { Holcomb } \\
(2000)\end{array}$ & $\begin{array}{l}\text { To identify the } \\
\text { activities of NPs } \\
\text { in PHC }\end{array}$ & $\begin{array}{l}\text { Cross- } \\
\text { sectional } \\
\text { survey } \\
\text { Delphi }\end{array}$ & $\begin{array}{l}131 \text { NPs } \\
\text { United States } \\
\text { study }\end{array}$ & $\begin{array}{l}\text { Socioeconomic } \\
\text { status }\end{array}$ & $\begin{array}{l}\text { Investigator } \\
\text { developed tools } \\
\text { 1) Survey tool- } \\
\text { consisting of a list }\end{array}$ & $\begin{array}{l}\text { Patients with } \\
\text { higher levels of } \\
\text { education } \\
\text { correlated with }\end{array}$ & $\begin{array}{l}\text { Study done in } \\
\text { the US, may } \\
\text { not be } \\
\text { representative }\end{array}$ \\
\hline
\end{tabular}




\begin{tabular}{|c|c|c|c|c|c|c|c|}
\hline Source & Purpose & Design & Sample & Concepts & Instruments & Results & Comments \\
\hline & & method & & & $\begin{array}{l}\text { of activities } \\
\text { 2) Demographic } \\
\text { information for } \\
\text { NPs }\end{array}$ & $\begin{array}{l}\text { the NP } \\
\text { performing a } \\
\text { smaller variety } \\
\text { of interventions } \\
\text { and teaching } \\
\text { activities }\end{array}$ & of Ontario NPs \\
\hline $\begin{array}{l}\text { Koren, } \\
\text { Mian, \& } \\
\text { Rukholm } \\
(2010)\end{array}$ & $\begin{array}{l}\text { To determine } \\
\text { employment and } \\
\text { practice } \\
\text { characteristics of } \\
\text { PHC NPs } \\
\text { practicing in } \\
\text { Ontario }\end{array}$ & $\begin{array}{l}\text { Cross- } \\
\text { sectional } \\
\text { survey }\end{array}$ & $\begin{array}{l}\text { PHC NPs } \\
\text { registered with } \\
\text { the College of } \\
\text { Nurses of } \\
\text { Ontario in } 2008 \\
\text { Survey sent to } \\
733 \text { PHC NPs in } \\
\text { Ontario } \\
\text { Ontario study }\end{array}$ & $\begin{array}{l}\text {-Patient age, } \\
\text { gender, illness, } \\
\text { socioeconomic } \\
\text { status }\end{array}$ & $\begin{array}{l}\text { Survey developed } \\
\text { by the CRaNHR } \\
\text { team in } \\
\text { consultation with } \\
\text { MOHLTC Nursing } \\
\text { Secretariat } \\
\text { Pilot tested for } \\
\text { validity and } \\
\text { readability }\end{array}$ & $\begin{array}{l}\text {-Response rate: } \\
68 \% \\
\text {-Increased } \\
\text { workload with } \\
\text { increasing age } \\
\text { of patients } \\
\text {-NPs report a } \\
\text { typical family } \\
\text { clientele } \\
\text {-A third of NPs } \\
\text { time is spent on } \\
\text { treatment of } \\
\text { minor illnesses, } \\
25 \% \text { on chronic } \\
\text { disease } \\
\text { management } \\
\text { - PHC NPs care } \\
\text { for } 62 \% \text { low- } \\
\text { income earners, } \\
46 \% \\
\text { unemployed } \\
\text { patients, and } \\
50 \% \text { substance } \\
\text { abusers }\end{array}$ & $\begin{array}{l}\text { Useful results; } \\
\text { however, } \\
\text { authors did not } \\
\text { relate findings } \\
\text { to NP patient } \\
\text { panel size }\end{array}$ \\
\hline $\begin{array}{l}\text { Koren, } \\
\text { Mian, \& } \\
\text { Rukholm } \\
(2010)\end{array}$ & $\begin{array}{l}\text { Highlight } \\
\text { demographic, } \\
\text { employment and } \\
\text { practice findings } \\
\text { from the } 2010\end{array}$ & $\begin{array}{l}\text { Cross- } \\
\text { sectional } \\
\text { survey }\end{array}$ & $\begin{array}{l}\text { PHC NPs } \\
\text { registered with } \\
\text { the College of } \\
\text { Nurses of } \\
\text { Ontario in } 2010\end{array}$ & Patient gender & $\begin{array}{l}\text { Survey developed } \\
\text { in consultation } \\
\text { with MOHLTC } \\
\text { Nursing } \\
\text { Secretariat and NP }\end{array}$ & $\begin{array}{l}\text { Response rate of } \\
38 \% \\
\text { NPs treat more } \\
\text { female patients }\end{array}$ & $\begin{array}{l}\text { Focus on rural } \\
\text { Ontario NPs } \\
\text { exclusively }\end{array}$ \\
\hline
\end{tabular}




\begin{tabular}{|c|c|c|c|c|c|c|c|}
\hline Source & Purpose & Design & Sample & Concepts & Instruments & Results & Comments \\
\hline & $\begin{array}{l}\text { survey of } \\
\text { Ontario's NP } \\
\text { workforce }\end{array}$ & & $\begin{array}{l}\text { Survey sent to } \\
991 \text { NPs in } \\
\text { Ontario }\end{array}$ & & $\begin{array}{l}\text { stakeholders } \\
\text { Pilot tested }\end{array}$ & & \\
\hline $\begin{array}{l}\text { Mian, } \\
\text { Lacarte, \& } \\
\text { Koren } \\
(2012)\end{array}$ & $\begin{array}{l}\text { To determine } \\
\text { employment and } \\
\text { practice } \\
\text { characteristics of } \\
\text { NPs practicing } \\
\text { in Ontario }\end{array}$ & $\begin{array}{l}\text { Cross- } \\
\text { sectional } \\
\text { survey }\end{array}$ & $\begin{array}{l}\text { NPs registered } \\
\text { with the College } \\
\text { of Nurses of } \\
\text { Ontario in } 2011 \\
\text { Survey sent to } \\
1,441 \text { NPs in } \\
\text { Ontario }\end{array}$ & Patient age & $\begin{array}{l}\text { Survey developed } \\
\text { by the CRaNHR } \\
\text { team in } \\
\text { consultation with } \\
\text { MOHLTC Nursing } \\
\text { Secretariat }\end{array}$ & $\begin{array}{l}\text { Response rate } \\
\text { of } 48 \% \\
73 \% \text { of NP } \\
\text { clientele was } \\
\text { composed of } \\
\text { seniors and } \\
\text { adults }\end{array}$ & $\begin{array}{l}\text { Data included } \\
\text { acute care NPs } \\
\text { working in } \\
\text { settings other } \\
\text { than PHC }\end{array}$ \\
\hline $\begin{array}{l}\text { Miller et al. } \\
(2004)\end{array}$ & $\begin{array}{l}\text { To determine the } \\
\text { feasibility of } \\
\text { implementing a } \\
\text { group medical } \\
\text { visit model with } \\
\text { low-income } \\
\text { women in an } \\
\text { inner-city PHC } \\
\text { clinic setting }\end{array}$ & $\begin{array}{l}\text { Case study } \\
\text { design }\end{array}$ & $\begin{array}{l}\text { Six group } \\
\text { medical visit } \\
\text { sessions } \\
28 \text { patients with } \\
\text { at least one } \\
\text { chronic illness } \\
\text { United States } \\
\text { study }\end{array}$ & $\begin{array}{l}\text { Chronic illness } \\
\text { on provider } \\
\text { productivity }\end{array}$ & $\begin{array}{l}\text { Open-ended } \\
\text { interviews } \\
\text { Chart reviews }\end{array}$ & $\begin{array}{l}\text { Group medical } \\
\text { visits for } \\
\text { chronic illness } \\
\text { did not improve } \\
\text { or change } \\
\text { provider } \\
\text { productivity }\end{array}$ & $\begin{array}{l}\text { Study done in } \\
\text { the US, may } \\
\text { not be } \\
\text { representative } \\
\text { of Ontario NPs }\end{array}$ \\
\hline $\begin{array}{l}\text { Morgan et } \\
\text { al. (2015) }\end{array}$ & $\begin{array}{l}\text { Compares } \\
\text { characteristics of } \\
\text { patient visits to } \\
\text { NPs, physician } \\
\text { assistants (PAs), } \\
\text { and physicians } \\
\text { in CHCs }\end{array}$ & $\begin{array}{l}\text { Cross- } \\
\text { sectional } \\
\text { survey }\end{array}$ & $\begin{array}{l}104 \text { CHCs } \\
670 \text { physicians } \\
245 \text { NPs } \\
103 \text { PAs } \\
\text { United States } \\
\text { study }\end{array}$ & $\begin{array}{l}\text { Patient gender } \\
\text { and health status }\end{array}$ & $\begin{array}{l}2006-2010 \text { annual } \\
\text { survey data from } \\
\text { the National } \\
\text { Ambulatory } \\
\text { Medical Care } \\
\text { Survey CHC } \\
\text { sample, a } \\
\text { representative } \\
\text { national sample of } \\
\text { CHC providers } \\
\text { and patient visits }\end{array}$ & $\begin{array}{l}\text {-NPs see more } \\
\text { females and } \\
\text { complete more } \\
\text { preventative } \\
\text { care than } \\
\text { physicians or } \\
\text { PAs } \\
\text {-NP patient } \\
\text { visits } \\
\text { statistically } \\
\text { different than } \\
\text { PAs' and } \\
\text { physicians' }\end{array}$ & $\begin{array}{l}\text { Study done in } \\
\text { the US, may } \\
\text { not be } \\
\text { representative } \\
\text { of Ontario NPs }\end{array}$ \\
\hline
\end{tabular}




\begin{tabular}{|c|c|c|c|c|c|c|c|}
\hline Source & Purpose & Design & Sample & Concepts & Instruments & Results & Comments \\
\hline $\begin{array}{l}\text { Muldoon, } \\
\text { Dahrouge, } \\
\text { Russell, } \\
\text { Hogg, \& } \\
\text { Ward (2012) }\end{array}$ & $\begin{array}{l}\text { Investigate the } \\
\text { relationship } \\
\text { between panel } \\
\text { size and quality } \\
\text { and outcomes of } \\
\text { individuals and } \\
\text { the contextual } \\
\text { factors that } \\
\text { affect it }\end{array}$ & $\begin{array}{l}\text { Literature } \\
\text { review }\end{array}$ & $\begin{array}{l}\text { Ontario CHC } \\
\text { study }\end{array}$ & $\begin{array}{l}\text { Patient health } \\
\text { status and socio- } \\
\text { economic status }\end{array}$ & Literature Review & $\begin{array}{l}\text {-Chronic illness } \\
\text { increases } \\
\text { provider } \\
\text { workload } \\
\text {-Patients with } \\
\text { low SES } \\
\text { increase } \\
\text { provider } \\
\text { workload }\end{array}$ & $\begin{array}{l}\text { Focus on } \\
\text { CHCs only in } \\
\text { Ontario } \\
\text { Focus on } \\
\text { physician } \\
\text { patient panel } \\
\text { size }\end{array}$ \\
\hline $\begin{array}{l}\text { Muldoon, } \\
\text { Rayner, and } \\
\text { Dahrouge } \\
(2013)\end{array}$ & $\begin{array}{l}\text { To determine if } \\
\text { patient poverty } \\
\text { is associated } \\
\text { with increased } \\
\text { workload for } \\
\text { primary care } \\
\text { providers } \\
\text { (PCPs) }\end{array}$ & $\begin{array}{l}\text { Linkage of } \\
\text { admin data } \\
\text { identifying } \\
\text { patient } \\
\text { poverty and } \\
\text { comorbidity } \\
\text { with survey } \\
\text { data about } \\
\text { the } \\
\text { organizationa } \\
1 \text { structure of } \\
\text { community } \\
\text { health } \\
\text { centres } \\
\text { (CHCs). }\end{array}$ & $\begin{array}{l}64 \text { Ontario } \\
\text { CHCs }\end{array}$ & $\begin{array}{l}\text { Patient } \\
\text { socioeconomic } \\
\text { status }\end{array}$ & $\begin{array}{l}\text { Administrative } \\
\text { data housed at the } \\
\text { Institute for } \\
\text { Clinical Evaluative } \\
\text { Sciences (ICES) } \\
\\
\text { Patient-level data } \\
\text { were extracted } \\
\text { from the CHCs' } \\
\text { electronic clinical } \\
\text { management } \\
\text { systems (CMSs) } \\
\text {-Organizational } \\
\text { survey }\end{array}$ & $\begin{array}{l}\text { Poor patients } \\
\text { generate a } \\
\text { higher workload } \\
\text { for PCPs in } \\
\text { CHCs } \\
\text { The CHCs with } \\
\text { higher } \\
\text { proportions of } \\
\text { poor patients } \\
\text { had smaller } \\
\text { panel sizes }\end{array}$ & $\begin{array}{l}\text { Focused only } \\
\text { on Ontario } \\
\text { CHCs }\end{array}$ \\
\hline $\begin{array}{l}\text { Oritz, Wan, } \\
\text { Meemon, } \\
\text { Paek, \& } \\
\text { Agiro } \\
(2010)\end{array}$ & $\begin{array}{l}\text { Examine the } \\
\text { relative } \\
\text { contribution of } \\
\text { NPs to rural } \\
\text { health clinics } \\
\text { (RHC) } \\
\text { productivity, } \\
\text { determine the } \\
\text { interrelationship } \\
\text { of efficiency } \\
\text { indicators of }\end{array}$ & $\begin{array}{l}\text { Secondary } \\
\text { data analysis }\end{array}$ & $\begin{array}{l}\text { 3,565 RHCs } \\
\text { United states } \\
\text { study }\end{array}$ & $\begin{array}{l}\text { Patient gender } \\
\text { and } \\
\text { socioeconomic } \\
\text { status }\end{array}$ & $\begin{array}{l}\text { There were two } \\
\text { principal sources } \\
\text { of study data: the } \\
\text { Medicare Cost } \\
\text { Report and the } \\
\text { Area Resource File } \\
\text { or ARF System } \\
\text { (Bureau of Health } \\
\text { Professions, 2007). } \\
\text { Additional sources } \\
\text { included the CMS }\end{array}$ & $\begin{array}{l}\text { NPs treat a high } \\
\text { proportion of } \\
\text { female patients } \\
\text { Lower } \\
\text { socioeconomic } \\
\text { status increases } \\
\text { provider } \\
\text { workload }\end{array}$ & $\begin{array}{l}\text { Focused on } \\
\text { RHCs } \\
\text { Survey done in } \\
\text { the US, may } \\
\text { not be } \\
\text { representative } \\
\text { of Ontario NPs }\end{array}$ \\
\hline
\end{tabular}




\begin{tabular}{|c|c|c|c|c|c|c|c|}
\hline Source & Purpose & Design & Sample & Concepts & Instruments & Results & Comments \\
\hline & $\begin{array}{l}\text { RHCs, and } \\
\text { identify } \\
\text { contextual and } \\
\text { structural factors } \\
\text { that influence } \\
\text { the variation in } \\
\text { efficiency }\end{array}$ & & & & $\begin{array}{l}\text { Online Survey } \\
\text { (2007) and } \\
\text { Certification } \\
\text { Reporting System } \\
\text { (OSCAR), the } \\
\text { Bureau of Labor } \\
\text { Statistics, the } \\
\text { Department of } \\
\text { Labor, and the } \\
\text { Bureau of Census } \\
\text { databases. }\end{array}$ & & \\
\hline $\begin{array}{l}\text { Poghosyan, } \\
\text { Lucero, } \\
\text { Rauch, \& } \\
\text { Berkowitz } \\
\text { (2012) }\end{array}$ & $\begin{array}{l}\text { Article discusses } \\
\text { NP topics such } \\
\text { as professional } \\
\text { identity, scope } \\
\text { of practice } \\
\text { regulations, } \\
\text { payment } \\
\text { regulations for } \\
\text { NP care, health } \\
\text { reform, patient } \\
\text { centered medical } \\
\text { homes, primary } \\
\text { care settings as } \\
\text { organizations, } \\
\text { and } \\
\text { research/practice } \\
\text { /policy } \\
\text { recommendation } \\
\text { s }\end{array}$ & $\begin{array}{l}\text { Discussion } \\
\text { article, not a } \\
\text { research } \\
\text { study }\end{array}$ & $\begin{array}{l}\text { United states } \\
\text { study }\end{array}$ & $\begin{array}{l}\text { Patient } \\
\text { socioeconomic } \\
\text { status }\end{array}$ & & $\begin{array}{l}\text { Lower } \\
\text { socioeconomic } \\
\text { status increases } \\
\text { provider } \\
\text { workload }\end{array}$ & $\begin{array}{l}\text { Report } \\
\text { completed in } \\
\text { the US, may } \\
\text { not be } \\
\text { representative } \\
\text { of Ontario NPs }\end{array}$ \\
\hline $\begin{array}{l}\text { Potts, } \\
\text { Adams, \& } \\
\text { Spadin, } \\
(2011)\end{array}$ & $\begin{array}{l}\text { To understand } \\
\text { how many NPs } \\
\text { were needed and } \\
\text { how they could } \\
\text { assist physicians }\end{array}$ & & $\begin{array}{l}37 \text { internists and } \\
8 \text { family practice } \\
\text { specialists with } \\
\text { average patient } \\
\text { panel size of }\end{array}$ & $\begin{array}{l}\text { Patient health } \\
\text { status }\end{array}$ & $\begin{array}{l}\text { Identified } 6 \\
\text { chronic illnesses, } \\
\text { attached a value, } \\
\text { compared to each } \\
\text { physician patient }\end{array}$ & $\begin{array}{l}\text { Patients } \\
\text { presenting with } \\
\text { chronic illnesses } \\
\text { (e.g., } \\
\text { hypertension, }\end{array}$ & $\begin{array}{l}\text { Study done in } \\
\text { the US, may } \\
\text { not be } \\
\text { representative } \\
\text { of Ontario NPS }\end{array}$ \\
\hline
\end{tabular}




\begin{tabular}{|c|c|c|c|c|c|c|c|}
\hline Source & Purpose & Design & Sample & Concepts & Instruments & Results & Comments \\
\hline & $\begin{array}{l}\text { with large } \\
\text { patient panels } \\
\text { with heavy } \\
\text { disease burden }\end{array}$ & & $\begin{array}{l}2,650 \\
\text { United states } \\
\text { study }\end{array}$ & & $\begin{array}{l}\text { panel in Ohio } \\
\text { region to } \\
\text { understand disease } \\
\text { burden and how } \\
\text { many NPs were } \\
\text { needed to support } \\
\text { the panel }\end{array}$ & $\begin{array}{l}\text { diabetes, renal } \\
\text { disease, } \\
\text { congestive heart } \\
\text { failure, mental } \\
\text { health and } \\
\text { addiction issues, } \\
\text { and co- } \\
\text { morbidities } \\
\text { require more } \\
\text { resources, care } \\
\text { coordination, } \\
\text { and provider } \\
\text { time in } \\
\text { comparison to } \\
\text { those presenting } \\
\text { with acute } \\
\text { illnesses }\end{array}$ & $\begin{array}{l}\text { Physician } \\
\text { focus }\end{array}$ \\
\hline $\begin{array}{l}\text { Rayner } \\
(2014)\end{array}$ & $\begin{array}{l}\text { The Community } \\
\text { Health Centre } \\
\text { (CHC) Panel } \\
\text { Size Handbook } \\
\text { outlines } \\
\text { procedures that } \\
\text { relate to (1) the } \\
\text { calculation of } \\
\text { current panel } \\
\text { sizes and (2) } \\
\text { adjusted target } \\
\text { panel sizes for } \\
\text { CHCs in } \\
\text { Ontario. } \\
\text { Following these } \\
\text { procedures will } \\
\text { ensure that all } \\
\text { CHCs calculate }\end{array}$ & & $\begin{array}{l}\text { NP, physician, } \\
\text { and other } \\
\text { healthcare } \\
\text { providers in } \\
\text { primary care } \\
\text { All ages patient } \\
\text { population } \\
\text { Ontario study }\end{array}$ & $\begin{array}{l}\text { Patient age, } \\
\text { gender, and } \\
\text { socioeconomic } \\
\text { status } \\
\text { Patient panel } \\
\text { size }\end{array}$ & $\begin{array}{l}\text { SAMI-- } \\
\text { Standardized } \\
\text { Adjusted Clinical } \\
\text { Group (ACG) } \\
\text { Morbidity Index }\end{array}$ & $\begin{array}{l}\text {-Age and gender } \\
\text { of clients is an } \\
\text { important factor } \\
\text { to take into } \\
\text { consideration } \\
\text { when measuring } \\
\text { provider } \\
\text { workload } \\
\text {-High } \\
\text { prevalence of } \\
\text { multiple } \\
\text { comorbidities in } \\
\text { CHCs in } \\
\text { Ontario and } \\
\text { how this must } \\
\text { be factored into } \\
\text { provider } \\
\text { workload }\end{array}$ & $\begin{array}{l}\text { Focus on CHC } \\
\text { and FHTs } \\
\text { Patient panel } \\
\text { size estimation } \\
\text { for CHCs only }\end{array}$ \\
\hline
\end{tabular}




\begin{tabular}{|c|c|c|c|c|c|c|c|}
\hline Source & Purpose & Design & Sample & Concepts & Instruments & Results & Comments \\
\hline & $\begin{array}{l}\text { panel size using } \\
\text { a consistent } \\
\text { formula. This } \\
\text { allows for } \\
\text { meaningful } \\
\text { comparisons and } \\
\text { reliable } \\
\text { projections. }\end{array}$ & & & & & $\begin{array}{l}\text {-High } \\
\text { prevalence of } \\
\text { poverty, } \\
\text { unemployment, } \\
\text { and } \\
\text { homelessness in } \\
\text { CHC clients in } \\
\text { Ontario } \\
\text { impacting } \\
\text { provider patient } \\
\text { panel size } \\
\text {-More likely to } \\
\text { be female }\end{array}$ & \\
\hline $\begin{array}{l}\text { Roots } \\
(2014)\end{array}$ & $\begin{array}{l}\text { Identify the } \\
\text { changes } \\
\text { associated with } \\
\text { the introduction } \\
\text { of the NP role } \\
\text { into fee-for- } \\
\text { service } \\
\text { community } \\
\text { based primary } \\
\text { care practices }\end{array}$ & $\begin{array}{l}\text { Multiple case } \\
\text { study using } \\
\text { mixed } \\
\text { methods }\end{array}$ & $\begin{array}{l}3 \text { sites- two } \\
\text { rural, one urban } \\
\text { in British } \\
\text { Columbia (BC) } \\
\text { GPs, NPs, other } \\
\text { practice staff, } \\
\text { community } \\
\text { based health } \\
\text { providers, health } \\
\text { authority } \\
\text { representative } \\
\text { from each site }\end{array}$ & -Patient age & $\begin{array}{l}\text {-Interviews, } \\
\text { observational data, } \\
\text { archival records, } \\
\text { chart reviews, field } \\
\text { notes }\end{array}$ & $\begin{array}{l}\text { Increased } \\
\text { workload with } \\
\text { increasing age } \\
\text { of patients }\end{array}$ & $\begin{array}{l}\text {-BC study, } \\
\text { results may not } \\
\text { be } \\
\text { representative } \\
\text { of Ontario NPs }\end{array}$ \\
\hline $\begin{array}{l}\text { Russell et al. } \\
(2009)\end{array}$ & $\begin{array}{l}\text { This study (1) } \\
\text { assessed } \\
\text { whether chronic } \\
\text { disease } \\
\text { management } \\
\text { differed among } \\
4 \text { models of } \\
\text { primary health } \\
\text { care delivery }\end{array}$ & $\begin{array}{l}\text { Cross- } \\
\text { sectional } \\
\text { survey }\end{array}$ & 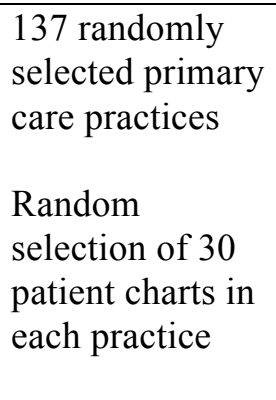 & Chronic illness & $\begin{array}{l}\text { Survey: clinician } \\
\text { questionnaire } \\
\text { Chart audit } \\
\text { Semi-structured } \\
\text { interviews with } \\
\text { physicians and } \\
\text { NPs }\end{array}$ & $\begin{array}{l}\text { Chronic disease } \\
\text { management } \\
\text { superior in } \\
\text { CHCs } \\
\text { High quality } \\
\text { chronic disease } \\
\text { management } \\
\text { was likely to be }\end{array}$ & $\begin{array}{l}\text { Focused on NP } \\
\text { effectiveness } \\
\text { of chronic } \\
\text { disease } \\
\text { management } \\
\text { versus how it } \\
\text { impacts NP } \\
\text { patient panel } \\
\text { size }\end{array}$ \\
\hline
\end{tabular}




\begin{tabular}{|c|c|c|c|c|c|c|c|}
\hline Source & Purpose & Design & Sample & Concepts & Instruments & Results & Comments \\
\hline & $\begin{array}{l}\text { and (2) } \\
\text { identified which } \\
\text { practice } \\
\text { organizational } \\
\text { factors were } \\
\text { independently } \\
\text { associated with } \\
\text { high-quality } \\
\text { care. }\end{array}$ & & $\begin{array}{l}1-2 \text { physicians } \\
\text { and NPs at each } \\
\text { site } \\
\text { Ontario study }\end{array}$ & & & $\begin{array}{l}\text { in the presence } \\
\text { of a NP }\end{array}$ & \\
\hline $\begin{array}{l}\text { Sangster- } \\
\text { Gormley et } \\
\text { al. (2012) }\end{array}$ & $\begin{array}{l}\text { To better } \\
\text { understand how } \\
\text { NPs in British } \\
\text { Columbia (BC) } \\
\text { are practicing } \\
\text { from Sept 2011- } \\
\text { January } 2012 \\
\end{array}$ & $\begin{array}{l}\text { Cross- } \\
\text { sectional } \\
\text { survey } \\
\text { design }\end{array}$ & $\begin{array}{l}37 \text { NPs returned } \\
\text { the survey in } \\
\text { British Columbia }\end{array}$ & Patient age & Survey & $\begin{array}{l}\text { NPs treat } 42 \% \\
\text { adults and } 13 \% \\
\text { seniors }\end{array}$ & $\begin{array}{l}\text { BC-based } \\
\text { study }\end{array}$ \\
\hline $\begin{array}{l}\text { Shortt, } \\
\text { Hogg, } \\
\text { Devlin, } \\
\text { Russell, \& } \\
\text { Muldoon, } \\
\text { (2012) }\end{array}$ & $\begin{array}{l}\text { To test the } \\
\text { accuracy of } \\
\text { imputing a } \\
\text { practice } \\
\text { population's } \\
\text { average } \\
\text { socioeconomic } \\
\text { characteristics } \\
\text { (such as average } \\
\text { education levels } \\
\text { and average } \\
\text { income) using } \\
\text { census data } \\
\text { centred on the } \\
\text { location of the } \\
\text { practice. }\end{array}$ & $\begin{array}{l}\text { Comparison } \\
\text { of census } \\
\text { data with } \\
\text { survey data } \\
\text { collected in } \\
\text { primary care } \\
\text { offices. }\end{array}$ & $\begin{array}{l}\text { A cross-sectional } \\
\text { sample of } \\
\text { patients from } \\
116 \text { urban } \\
\text { practices. } \\
\text { Ontario study }\end{array}$ & $\begin{array}{l}\text { Patient age, } \\
\text { gender, and } \\
\text { socioeconomic } \\
\text { status }\end{array}$ & $\begin{array}{l}4413 \text { patient } \\
\text { surveys were } \\
\text { collected and } \\
\text { compared to } \\
\text { census data }\end{array}$ & $\begin{array}{l}\text { CHC client } \\
\text { populations } \\
\text { found that } \\
\text { patients were } \\
\text { older, poorer, } \\
\text { and more likely } \\
\text { to be female }\end{array}$ & $\begin{array}{l}\text { Focus on all } \\
\text { CHC primary } \\
\text { care providers, } \\
\text { not exclusive } \\
\text { to NPs and all } \\
\text { PHC practice } \\
\text { models }\end{array}$ \\
\hline
\end{tabular}




\begin{tabular}{|c|c|c|c|c|c|c|c|}
\hline Source & Purpose & Design & Sample & Concepts & Instruments & Results & Comments \\
\hline $\begin{array}{l}\text { Sloan, Pong, } \\
\text { Rukholm, \& } \\
\text { Caty (2006) }\end{array}$ & $\begin{array}{l}\text { To conduct a } \\
\text { survey of all } \\
\text { PHC NPs and } \\
\text { ACNPs, in order } \\
\text { to describe NPs } \\
\text { in Ontario with } \\
\text { respect to their } \\
\text { demographic } \\
\text { characteristics, } \\
\text { geographic } \\
\text { distribution, } \\
\text { employment } \\
\text { trends and } \\
\text { practice profiles }\end{array}$ & $\begin{array}{l}\text { Cross- } \\
\text { sectional } \\
\text { survey }\end{array}$ & $\begin{array}{l}\text { All NPs } \\
\text { practicing in } \\
\text { Ontario in } 2004 \\
\text { Survey mailed to } \\
621 \text { NPs }\end{array}$ & $\begin{array}{l}\text { Patient age } \\
\text { Patient gender } \\
\text { Socioeconomic } \\
\text { status }\end{array}$ & $\begin{array}{l}\text { Questionnaire for } \\
\text { both PHC NPs and } \\
\text { ACNPs was } \\
\text { developed in } \\
\text { consultation with } \\
\text { the Advisory } \\
\text { Committee for the } \\
\text { NPAO Electronic } \\
\text { Registry Project } \\
\text { and with the } \\
\text { Project Manager } \\
\text { Pilot tested for } \\
\text { content validity }\end{array}$ & $\begin{array}{l}\text {-Response rate } \\
60 \% \\
\text {-NPs treat a } \\
\text { typical family } \\
\text { clientele } \\
\text {-NPs treat a } \\
\text { high number of } \\
\text { female patients } \\
\text { with more } \\
\text { complex health } \\
\text { issues } \\
\text {-NPs describe } \\
\text { their client } \\
\text { population as } \\
\text { low-income } \\
\text { earners, } \\
\text { unemployed, } \\
\text { substance } \\
\text { abusers, } \\
\text { mentally ill, } \\
\text { cultural } \\
\text { minorities, and } \\
\text { recent } \\
\text { immigrants }\end{array}$ & $\begin{array}{l}\text { Results } \\
\text { represent acute } \\
\text { care and PHC } \\
\text { NPs }\end{array}$ \\
\hline VHA (2009) & $\begin{array}{l}\text { Establishes the } \\
\text { guidelines for } \\
\text { use of PHC } \\
\text { Management } \\
\text { Module at all } \\
\text { VHA Primary } \\
\text { Care sites of } \\
\text { care. }\end{array}$ & & $\begin{array}{l}\text { United States } \\
\text { report }\end{array}$ & $\begin{array}{l}\text { Age and gender } \\
\text { of patient } \\
\text { Socioeconomic } \\
\text { status }\end{array}$ & & $\begin{array}{l}\text {-Increasing age } \\
\text { of patients' } \\
\text { results in } \\
\text { increased } \\
\text { workload for the } \\
\text { provider } \\
\text {-NPs treat a } \\
\text { high number of } \\
\text { female patients, } \\
\text { who often make } \\
\text { more frequent }\end{array}$ & $\begin{array}{l}\text { US report and } \\
\text { data, may not } \\
\text { be } \\
\text { representative } \\
\text { of Ontario NPs }\end{array}$ \\
\hline
\end{tabular}




\begin{tabular}{|c|c|c|c|c|c|c|c|}
\hline Source & Purpose & Design & Sample & Concepts & Instruments & Results & Comments \\
\hline & & & & & & $\begin{array}{l}\text { visits, and have } \\
\text { more complex } \\
\text { health issues } \\
\text {-Chronic illness } \\
\text { requires more } \\
\text { provider time } \\
\text {-Low SES } \\
\text { increases } \\
\text { provider } \\
\text { workload }\end{array}$ & \\
\hline VHA (2014) & $\begin{array}{l}\text { This Veterans } \\
\text { Health } \\
\text { Administration } \\
\text { (VHA) } \\
\text { Handbook } \\
\text { establishes the } \\
\text { procedures for } \\
\text { Patient Aligned } \\
\text { Care Teams } \\
\text { (PACTs) to } \\
\text { provide } \\
\text { Veterans with } \\
\text { primary care that } \\
\text { is patient- } \\
\text { centered, data } \\
\text { driven, } \\
\text { continuously } \\
\text { improving, } \\
\text { team-based, } \\
\text { accessible, } \\
\text { timely, } \\
\text { comprehensive, } \\
\text { coordinated, and } \\
\text { provides } \\
\text { continuity of }\end{array}$ & & $\begin{array}{l}\text { United States } \\
\text { report }\end{array}$ & $\begin{array}{l}\text { Age and gender } \\
\text { of patient } \\
\text { Patient } \\
\text { socioeconomic } \\
\text { status }\end{array}$ & & $\begin{array}{l}\text {-Increasing age } \\
\text { of patients } \\
\text { results in } \\
\text { increased } \\
\text { workload for the } \\
\text { provider } \\
\text {-NPs treat a } \\
\text { high number of } \\
\text { female patients, } \\
\text { whom often } \\
\text { make more } \\
\text { frequent visits, } \\
\text { and have more } \\
\text { complex health } \\
\text { issues } \\
\text {-Chronic illness } \\
\text { requires more } \\
\text { provider time } \\
\text {-Low SES } \\
\text { increases } \\
\text { provider } \\
\text { workload }\end{array}$ & $\begin{array}{l}\text { US report and } \\
\text { data, may not } \\
\text { be } \\
\text { representative } \\
\text { of Ontario NPs }\end{array}$ \\
\hline
\end{tabular}




\begin{tabular}{|c|c|c|c|c|c|c|c|}
\hline Source & Purpose & Design & Sample & Concepts & Instruments & Results & Comments \\
\hline & care over time. & & & & & & \\
\hline $\begin{array}{l}\text { Watts et al. } \\
\text { (2009) }\end{array}$ & $\begin{array}{l}\text { To describe the } \\
\text { role of NPs in } \\
\text { shared medical } \\
\text { appointments/gr } \\
\text { oup visits based } \\
\text { on the chronic } \\
\text { care model }\end{array}$ & Case study & $\begin{array}{l}\text { Three specific } \\
\text { chronic illnesses } \\
\text { groups--diabetes, } \\
\text { heart failure, and } \\
\text { hypertension } \\
3 \mathrm{NPs} \\
\text { United states } \\
\text { study }\end{array}$ & $\begin{array}{l}\text { Patient health } \\
\text { status } \\
\text { Chronic Illness }\end{array}$ & $\begin{array}{l}\text { Interviews with } \\
\text { participating staff } \\
\text { and convenience } \\
\text { sample of patients } \\
\text { from each group }\end{array}$ & $\begin{array}{l}\text { Group visits } \\
\text { decrease } \\
\text { provider (NP) } \\
\text { backlog, lower } \\
\text { costs, provide } \\
\text { timely } \\
\text { appointments, } \\
\text { improve patient } \\
\text { satisfaction, and } \\
\text { increase } \\
\text { effectiveness of } \\
\text { chronic illness } \\
\text { management }\end{array}$ & $\begin{array}{l}\text { Study done in } \\
\text { the US, may } \\
\text { not be } \\
\text { representative } \\
\text { of Ontario NPs }\end{array}$ \\
\hline $\begin{array}{l}\text { Way, Jones, } \\
\text { Baskerville } \\
\text { \& Busing } \\
(2001)\end{array}$ & $\begin{array}{l}\text { To determine } \\
\text { what services } \\
\text { are provided by } \\
\text { NPs and family } \\
\text { physicians (FP) } \\
\text { in a rural } \\
\text { practice settings }\end{array}$ & Case study & $\begin{array}{l}2 \text { NPs, } 4 \text { FPs } \\
400 \text { patient } \\
\text { encounters } \\
\text { Ontario study }\end{array}$ & NP role clarity & $\begin{array}{l}\text { Data analyzed } \\
\text { from } 122 \mathrm{NP} \\
\text { patient encounters } \\
\text { and } 278 \mathrm{FP} \text { patient } \\
\text { encounters to } \\
\text { determine frequent } \\
\text { activities and } \\
\text { practice patterns }\end{array}$ & $\begin{array}{l}\text { Chronic illness } \\
\text { increases } \\
\text { provider } \\
\text { workload }\end{array}$ & $\begin{array}{l}\text { Physician } \\
\text { focused } \\
\text { Focus on rural } \\
\text { NP/FP } \\
\text { activities that } \\
\text { may vary in } \\
\text { other PHC } \\
\text { settings }\end{array}$ \\
\hline
\end{tabular}




\section{Appendix C}

\section{Summary of Literature Examining NP-related Factors}

\begin{tabular}{|c|c|c|c|c|c|c|c|}
\hline Source & Purpose & Design & Sample & Concepts & Instruments & Results & Comments \\
\hline $\begin{array}{l}\text { Buerhaus, } \\
\text { DesRoches, } \\
\text { Dittus, \& } \\
\text { Donelan, } \\
(2015)\end{array}$ & $\begin{array}{l}\text { The purpose of } \\
\text { this study was } \\
\text { to identify } \\
\text { demographic } \\
\text { and practice } \\
\text { characteristics } \\
\text { of primary care } \\
\text { NPs (PCNPs) } \\
\text { and compare } \\
\text { these } \\
\text { characteristics } \\
\text { with primary } \\
\text { care physicians } \\
\text { (PCMDs) }\end{array}$ & $\begin{array}{l}\text { Cross- } \\
\text { sectional } \\
\text { survey }\end{array}$ & $\begin{array}{l}\text { From November } \\
23,2011 \text {, to April } \\
9,2012, \text { we } \\
\text { conducted a } \\
\text { national postal } \\
\text { mail survey of } \\
972 \text { clinicians } \\
\text { (467 PCNPs and } \\
505 \text { PCMDs) } \\
\text { United states } \\
\text { study }\end{array}$ & $\begin{array}{l}\text { NP employment } \\
\text { status }\end{array}$ & $\begin{array}{l}\text { Questionnaire } \\
\text { domains } \\
\text { included } \\
\text { compensation } \\
\text { and billing } \\
\text { practices; } \\
\text { characteristics } \\
\text { of patients } \\
\text { treated; PCNPs' } \\
\text { use of their own } \\
\text { National } \\
\text { Provider } \\
\text { Identification } \\
\text { number to bill } \\
\text { services; how } \\
\text { PCNPs spend } \\
\text { their time; } \\
\text { clinical and } \\
\text { nonclinical } \\
\text { activities } \\
\text { performed; and } \\
\text { whether PCNPs } \\
\text { have privileges } \\
\text { to admit, round } \\
\text { on (i.e., oversee } \\
\text { the care } \\
\text { provided to) } \\
\text { patients, and } \\
\text { write orders } \\
\text { independently of } \\
\text { physicians. The }\end{array}$ & $\begin{array}{l}\text { PCNPs work less } \\
\text { hours and see } \\
\text { fewer patients, } \\
\text { and only a handful } \\
\text { of PCNPs have } \\
\text { their salary } \\
\text { adjusted for } \\
\text { productivity and } \\
\text { quality } \\
\text { performance }\end{array}$ & $\begin{array}{l}\text { Study done in } \\
\text { the US, may } \\
\text { not be } \\
\text { representative } \\
\text { of Ontario NPs }\end{array}$ \\
\hline
\end{tabular}




\begin{tabular}{|c|c|c|c|c|c|c|c|}
\hline Source & Purpose & Design & Sample & Concepts & Instruments & Results & Comments \\
\hline & & & & & $\begin{array}{l}\text { response rate } \\
\text { was } 61.2 \%\end{array}$ & & \\
\hline $\begin{array}{l}\text { Dierick-van } \\
\text { Daele et al. } \\
(2009)\end{array}$ & $\begin{array}{l}\text { Evaluate } \\
\text { process and } \\
\text { outcomes of } \\
\text { care provided to } \\
\text { patients with } \\
\text { common } \\
\text { complaints by } \\
\text { general } \\
\text { practitioners or } \\
\text { specially } \\
\text { trained NPs as } \\
\text { first point of } \\
\text { contact }\end{array}$ & $\begin{array}{l}\text { Randomized } \\
\text { control trial }\end{array}$ & $\begin{array}{l}1501 \text { patients in } \\
15 \text { general } \\
\text { practices were } \\
\text { randomly } \\
\text { assigned to a } \\
\text { general } \\
\text { practitioner or a } \\
\text { NP } \\
\text { Netherlands study }\end{array}$ & $\begin{array}{l}\text { Years of } \\
\text { experience }\end{array}$ & $\begin{array}{l}\text { Questionnaires } \\
\text { Extracting } \\
\text { medical records } \\
\text { from practice } \\
\text { computer } \\
\text { systems and } \\
\text { recording the } \\
\text { length of } \\
\text { consultations }\end{array}$ & $\begin{array}{l}\text { Patients in the NP } \\
\text { group had more } \\
\text { follow up } \\
\text { consultations and } \\
\text { visits with NPs } \\
\text { took longer }\end{array}$ & $\begin{array}{l}\text { Dutch study } \\
\text { Focused on } \\
\text { comparing } \\
\text { NPs to } \\
\text { physicians }\end{array}$ \\
\hline $\begin{array}{l}\text { Dierick-van } \\
\text { Daele et al. } \\
(2010)\end{array}$ & $\begin{array}{l}\text { To estimate } \\
\text { costs of GP } \\
\text { versus NP } \\
\text { consultations } \\
\text { from practice } \\
\text { and societal } \\
\text { perspectives }\end{array}$ & $\begin{array}{l}\text { Randomized } \\
\text { control trial } \\
(\mathrm{RCT})\end{array}$ & $\begin{array}{l}\text { Patients were } \\
\text { randomly } \\
\text { allocated to GP or } \\
\text { NP consultation }\end{array}$ & $\begin{array}{l}\text { Years of } \\
\text { experience }\end{array}$ & $\begin{array}{l}\text { Chart reviews to } \\
\text { evaluate } \\
\text { resource use, } \\
\text { follow-up } \\
\text { consultations, } \\
\text { length of } \\
\text { consultations, } \\
\text { and salary costs }\end{array}$ & $\begin{array}{l}\text { To be cost } \\
\text { effective must } \\
\text { have the right skill } \\
\text { mix among NP } \\
\text { staff and } \\
\text { physician staff }\end{array}$ & $\begin{array}{l}\text { Dutch study } \\
\text { Focused on } \\
\text { NP cost- } \\
\text { effectiveness } \\
\text { Also provided } \\
\text { relevant results } \\
\text { on types of } \\
\text { patients NPs } \\
\text { treat }\end{array}$ \\
\hline $\begin{array}{l}\text { Dierick-van } \\
\text { Daele et al. } \\
(2011)\end{array}$ & $\begin{array}{l}\text { Examines the } \\
\text { potential } \\
\text { economic } \\
\text { viability of } \\
\text { nurse } \\
\text { practitioner } \\
\text { employment in } \\
\text { Dutch general } \\
\text { practices. }\end{array}$ & $\begin{array}{l}\text { Descriptive/ } \\
\text { exploratory } \\
\text { study }\end{array}$ & $\begin{array}{l}\text { GPs employing } \\
\text { NPs }(n=132) \\
\text { Health insures ( } n \\
=12) \\
\text { Netherlands study }\end{array}$ & $\begin{array}{l}\text { Years of } \\
\text { experience }\end{array}$ & $\begin{array}{l}\text { Two } \\
\text { questionnaires }\end{array}$ & $\begin{array}{l}\text { To be cost- } \\
\text { effective, must } \\
\text { have the right skill } \\
\text { mix among NP } \\
\text { staff and } \\
\text { physician staff } \\
\text { NPs take longer } \\
\text { doing } \\
\text { consultations }\end{array}$ & $\begin{array}{l}\text { Dutch study } \\
\text { Focused on } \\
\text { NP cost- } \\
\text { effectiveness } \\
\text { Also provided } \\
\text { relevant results } \\
\text { on NP } \\
\text { characteristics }\end{array}$ \\
\hline
\end{tabular}




\begin{tabular}{|c|c|c|c|c|c|c|c|}
\hline Source & Purpose & Design & Sample & Concepts & Instruments & Results & Comments \\
\hline $\begin{array}{l}\text { Donald et al. } \\
\text { (2010) }\end{array}$ & $\begin{array}{l}\text { To develop a } \\
\text { better } \\
\text { understanding } \\
\text { of advanced } \\
\text { practice nursing } \\
\text { roles, their } \\
\text { current use, and } \\
\text { the individual, } \\
\text { organizational } \\
\text { and health } \\
\text { system factors } \\
\text { that influence } \\
\text { their effective } \\
\text { development } \\
\text { and integration }\end{array}$ & $\begin{array}{l}\text { Literature } \\
\text { Review }\end{array}$ & $\begin{array}{l}468 \text { articles } \\
\text { Interviews ( } n= \\
62) \text { and focus } \\
\text { groups ( } n=4 \\
\text { with a total of } 19 \\
\text { NPs) } \\
\text { Ontario study }\end{array}$ & NP role clarity & $\begin{array}{l}\text { Literature } \\
\text { review and key } \\
\text { informant } \\
\text { interviews }\end{array}$ & $\begin{array}{l}\text { Lack of role } \\
\text { clarity results in } \\
\text { lack of planning } \\
\text { for the role, } \\
\text { clearly defined } \\
\text { goals are not } \\
\text { outlined, and } \\
\text { outcomes and } \\
\text { potential impacts } \\
\text { of the role are not } \\
\text { evaluated properly }\end{array}$ & $\begin{array}{l}\text { Relevant NP } \\
\text { data, however, } \\
\text { did not relate } \\
\text { results to } \\
\text { impact to NP } \\
\text { patient panel } \\
\text { size }\end{array}$ \\
\hline $\begin{array}{l}\text { Donelan, } \\
\text { DesRoches, } \\
\text { Dittus, \& } \\
\text { Buerhaus } \\
\text { (2013) }\end{array}$ & $\begin{array}{l}\text { To examine the } \\
\text { scope of NP } \\
\text { practice }\end{array}$ & $\begin{array}{l}\text { Cross- } \\
\text { sectional } \\
\text { survey }\end{array}$ & $\begin{array}{l}505 \text { physicians } \\
467 \text { NPs in PHC } \\
\text { United states } \\
\text { study }\end{array}$ & $\begin{array}{l}\text { NP employment } \\
\text { status }\end{array}$ & $\begin{array}{l}\text { Survey } \\
\text { addressing } \\
\text { scope of work, } \\
\text { practice } \\
\text { characteristics, } \\
\text { and attitudes } \\
\text { about the effect } \\
\text { of expanding the } \\
\text { NP scope of } \\
\text { practice }\end{array}$ & $\begin{array}{l}\text { Response rate: } \\
61.2 \% \\
\text { NPs that were } \\
\text { full-time } \\
\text { employees in } \\
\text { various PHC } \\
\text { clinics increased } \\
\text { productivity, } \\
\text { depends on clinic } \\
\text { size }\end{array}$ & $\begin{array}{l}\text { Study done in } \\
\text { the US, may } \\
\text { not be } \\
\text { representative } \\
\text { of Ontario NPs }\end{array}$ \\
\hline $\begin{array}{l}\text { Humbert et } \\
\text { al. (2007) }\end{array}$ & $\begin{array}{l}\text { Evaluate the } \\
\text { efficacy of } \\
\text { integrating a NP } \\
\text { into PHC } \\
\text { settings with } \\
\text { interdisciplinary } \\
\text { teams and the } \\
\text { effect on } \\
\text { patients with } \\
\text { multiple }\end{array}$ & $\begin{array}{l}\text { Randomized } \\
\text { control trial }\end{array}$ & $\begin{array}{l}3 \text { NPs each had } \\
40 \text { patients } \\
\text { Ontario study }\end{array}$ & $\begin{array}{l}\text {-NP role } \\
\text { confusion }\end{array}$ & $\begin{array}{l}\text { Home visit data } \\
\text { collection } \\
\text { Care planning }\end{array}$ & $\begin{array}{l}\text { Understanding NP } \\
\text { role is crucial for } \\
\text { it to be used } \\
\text { appropriately to } \\
\text { benefit patient } \\
\text { care }\end{array}$ & $\begin{array}{l}\text { Focus on rural } \\
\text { healthcare }\end{array}$ \\
\hline
\end{tabular}




\begin{tabular}{|c|c|c|c|c|c|c|c|}
\hline Source & Purpose & Design & Sample & Concepts & Instruments & Results & Comments \\
\hline & $\begin{array}{l}\text { chronic } \\
\text { illnesses }\end{array}$ & & & & & & \\
\hline $\begin{array}{l}\text { IBM } \\
\text { Business } \\
\text { Consulting } \\
\text { Services } \\
(2003)\end{array}$ & $\begin{array}{l}\text { To examine } \\
\text { barriers and } \\
\text { facilitators to } \\
\text { encourage } \\
\text { further } \\
\text { integration of } \\
\text { NPs into } \\
\text { specific practice } \\
\text { settings }\end{array}$ & $\begin{array}{l}\text { Cross- } \\
\text { sectional } \\
\text { survey } \\
\text { design }\end{array}$ & $\begin{array}{l}476 \text { NPs } \\
500 \text { Physicians } \\
\text { Ontario report }\end{array}$ & NP role clarity & $\begin{array}{l}\text { Literature } \\
\text { Review } \\
\text { NP Survey- } \\
\text { response rate } \\
77 \% \\
\text { Physician } \\
\text { Survey } \\
\text { Site visits } \\
\text { Patient survey } \\
\text { Population- } \\
\text { based survey }\end{array}$ & $\begin{array}{l}\text { Whether or not a } \\
\text { NP's role is } \\
\text { clearly defined } \\
\text { was a predictor of } \\
\text { NPs integration } \\
\text { into } \\
\text { interdisciplinary } \\
\text { practice settings } \\
\text { NPs with a clearly } \\
\text { defined role are } \\
\text { more likely to be } \\
\text { satisfied with their } \\
\text { role and both } \\
\text { physician and NPs } \\
\text { are less likely to } \\
\text { express concern } \\
\text { regarding NP } \\
\text { scope and/or } \\
\text { liability }\end{array}$ & $\begin{array}{l}\text { Not specific to } \\
\text { NP patient } \\
\text { panel size; } \\
\text { however, } \\
\text { provided } \\
\text { relevant NP } \\
\text { data }\end{array}$ \\
\hline $\begin{array}{l}\text { Johnson } \\
\text { (2005) }\end{array}$ & $\begin{array}{l}\text { To uncover } \\
\text { patterns across } \\
\text { NP experiences } \\
\text { that contribute } \\
\text { to } \\
\text { understanding } \\
\text { their } \\
\text { perceptions of } \\
\text { managed care, } \\
\text { how it affects } \\
\text { daily practice, } \\
\text { and how NPs } \\
\text { respond to a }\end{array}$ & $\begin{array}{l}\text { Descriptive } \\
\text { Qualitative }\end{array}$ & $\begin{array}{l}14 \text { NPs with three } \\
\text { years minimum } \\
\text { experience } \\
\text { New England } \\
\text { study }\end{array}$ & $\begin{array}{l}\text { Years of } \\
\text { experience }\end{array}$ & $\begin{array}{l}\text { In-depth } \\
\text { interviews }\end{array}$ & $\begin{array}{l}\text { Novice NPs have } \\
\text { a more difficult } \\
\text { time transitioning } \\
\text { into managed care } \\
\text { PHC } \\
\text { environments in } \\
\text { comparison to } \\
\text { senior } \\
\text { practitioners }\end{array}$ & $\begin{array}{l}\text { Study done in } \\
\text { New England } \\
\text { may not } \\
\text { represent } \\
\text { Ontario NPs }\end{array}$ \\
\hline
\end{tabular}




\begin{tabular}{|c|c|c|c|c|c|c|c|}
\hline Source & Purpose & Design & Sample & Concepts & Instruments & Results & Comments \\
\hline & $\begin{array}{l}\text { changing } \\
\text { managed care } \\
\text { workplace }\end{array}$ & & & & & & \\
\hline $\begin{array}{l}\text { Koren, Mian, } \\
\text { \& Rukholm } \\
(2010)\end{array}$ & $\begin{array}{l}\text { To determine } \\
\text { employment } \\
\text { and practice } \\
\text { characteristics } \\
\text { of PHC NPs } \\
\text { practicing in } \\
\text { Ontario }\end{array}$ & $\begin{array}{l}\text { Cross- } \\
\text { sectional } \\
\text { survey }\end{array}$ & $\begin{array}{l}\text { PHC NPs } \\
\text { registered with } \\
\text { the College of } \\
\text { Nurses of Ontario } \\
\text { in } 2008 \\
\text { Survey sent to } \\
733 \text { PHC NPs in } \\
\text { Ontario }\end{array}$ & $\begin{array}{l}\text { NP education } \\
\text { and prior } \\
\text { nursing } \\
\text { experience } \\
\text { NP role } \\
\text { confusion }\end{array}$ & $\begin{array}{l}\text { Survey } \\
\text { developed by } \\
\text { the CRaNHR } \\
\text { team in } \\
\text { consultation } \\
\text { with MOHLTC } \\
\text { Nursing } \\
\text { Secretariat } \\
\text { Pilot tested for } \\
\text { validity and } \\
\text { readability }\end{array}$ & $\begin{array}{l}\text {-Response rate of } \\
68 \% \\
-70 \% \text { reported } \\
\text { having a Council } \\
\text { of Ontario } \\
\text { University } \\
\text { Programs in } \\
\text { Nursing } \\
\text { (COUPN) } \\
\text { certificate or } \\
\text { equivalent as the } \\
\text { highest level of } \\
\text { nursing education } \\
\text { and } 22 \% \text { reported } \\
\text { having a master's } \\
\text { degree in nursing } \\
\text {-The physician } \\
\text { NPs worked with } \\
\text { most often had a } \\
\text { strong } \\
\text { understanding of } \\
\text { their role and } \\
\text { supported the NP } \\
\text { to practice to their } \\
\text { full scope; } \\
\text { physicians outside } \\
\text { of the practice } \\
\text { lacked this } \\
\text { understanding }\end{array}$ & $\begin{array}{l}\text { Relevant NP } \\
\text { data; however, } \\
\text { did not relate } \\
\text { data to NP } \\
\text { patient panel } \\
\text { size }\end{array}$ \\
\hline $\begin{array}{l}\text { Martin- } \\
\text { Misener et al. } \\
\text { (2010) }\end{array}$ & $\begin{array}{l}\text { To examine the } \\
\text { practice } \\
\text { patterns of NPs }\end{array}$ & $\begin{array}{l}\text { Cross- } \\
\text { sectional } \\
\text { survey }\end{array}$ & $\begin{array}{l}\text { Survey sent to } 55 \\
\text { NPs, } 39 \\
\text { responded }\end{array}$ & $\begin{array}{l}\text { Years of } \\
\text { experience } \\
\text { practicing as a }\end{array}$ & Survey & $\begin{array}{l}\text {-Response rate } \\
\text { was } 71 \% \\
\text {-Found a wide }\end{array}$ & $\begin{array}{l}\text { Study specific } \\
\text { to Nova Scotia } \\
\text { NPs }\end{array}$ \\
\hline
\end{tabular}




\begin{tabular}{|c|c|c|c|c|c|c|c|}
\hline Source & Purpose & Design & Sample & Concepts & Instruments & Results & Comments \\
\hline & $\begin{array}{l}\text { in primary } \\
\text { health care in } \\
\text { Nova Scotia }\end{array}$ & & Nova Scotia study & $\begin{array}{l}\text { NP } \\
\text { Prior nursing } \\
\text { experience } \\
\text { NP education } \\
\text { NP employment } \\
\text { status } \\
\text { NP role clarity }\end{array}$ & & $\begin{array}{l}\text { array of NP } \\
\text { educational } \\
\text { backgrounds and } \\
\text { prior nursing } \\
\text { experience. The } \\
\text { majority of } \\
\text { respondents had a } \\
\text { masters with a NP } \\
\text { degree, with a } \\
\text { mean of } 24 \text { years } \\
\text { of prior nursing } \\
\text { experience, and } \\
\text { five years working } \\
\text { as a NP } \\
\text {-Most NPs were } \\
\text { employed full- } \\
\text { time in either a } \\
\text { community health } \\
\text { center or family } \\
\text { practice in Nova } \\
\text { Scotia } \\
\text {-Physicians } \\
\text { outside of practice } \\
\text { refuse referrals } \\
\text { due to not } \\
\text { understanding NP } \\
\text { role }\end{array}$ & $\begin{array}{l}\text { Small sample } \\
\text { size }\end{array}$ \\
\hline $\begin{array}{l}\text { Miller et al. } \\
(2004)\end{array}$ & $\begin{array}{l}\text { To determine } \\
\text { the feasibility of } \\
\text { implementing a } \\
\text { group medical } \\
\text { visit model with } \\
\text { low-income } \\
\text { women in an } \\
\text { inner-city PHC }\end{array}$ & $\begin{array}{l}\text { Case study } \\
\text { design }\end{array}$ & $\begin{array}{l}\text { Six group medical } \\
\text { visit sessions } \\
28 \text { patients with at } \\
\text { least one chronic } \\
\text { illness } \\
\text { United states }\end{array}$ & $\begin{array}{l}\text { Provider } \\
\text { productivity } \\
\text { Role clarity }\end{array}$ & $\begin{array}{l}\text { Open-ended } \\
\text { interviews } \\
\text { Chart reviews }\end{array}$ & $\begin{array}{l}\text { An example of } \\
\text { where physicians } \\
\text { and NPs worked } \\
\text { in equivalent roles } \\
\text { and had a strong } \\
\text { understanding of } \\
\text { their tasks within } \\
\text { a group medical }\end{array}$ & $\begin{array}{l}\text { Study done in } \\
\text { the US, may } \\
\text { not be } \\
\text { representative } \\
\text { of Ontario NPs }\end{array}$ \\
\hline
\end{tabular}




\begin{tabular}{|c|c|c|c|c|c|c|c|}
\hline Source & Purpose & Design & Sample & Concepts & Instruments & Results & Comments \\
\hline & clinic setting & & study & & & $\begin{array}{l}\text { visit, and how this } \\
\text { increased } \\
\text { productivity and } \\
\text { produced positive } \\
\text { patient health } \\
\text { outcomes }\end{array}$ & \\
\hline $\begin{array}{l}\text { Oritz et al. } \\
(2010)\end{array}$ & $\begin{array}{l}\text { Examine the } \\
\text { relative } \\
\text { contribution of } \\
\text { NPs to rural } \\
\text { health clinics } \\
\text { (RHC) } \\
\text { productivity, } \\
\text { determine the } \\
\text { interrelationship } \\
\text { of efficiency } \\
\text { indicators of } \\
\text { RHCs, and } \\
\text { identify } \\
\text { contextual and } \\
\text { structural } \\
\text { factors that } \\
\text { influence the } \\
\text { variation in } \\
\text { efficiency }\end{array}$ & $\begin{array}{l}\text { Secondary } \\
\text { data analysis }\end{array}$ & $\begin{array}{l}\text { 3,565 RHCs } \\
\text { United states } \\
\text { study }\end{array}$ & $\begin{array}{l}\text { NP employment } \\
\text { status }\end{array}$ & $\begin{array}{l}\text { There were two } \\
\text { principal } \\
\text { sources of study } \\
\text { data: the } \\
\text { Medicare Cost } \\
\text { Report and the } \\
\text { Area Resource } \\
\text { File (ARF) } \\
\text { System } \\
\text { Additional } \\
\text { sources included } \\
\text { the CMS Online } \\
\text { Survey (2007) } \\
\text { and Certification } \\
\text { Reporting } \\
\text { System } \\
\text { (OSCAR), the } \\
\text { Bureau of Labor } \\
\text { Statistics, the } \\
\text { Department of } \\
\text { Labor, and the } \\
\text { Bureau of } \\
\text { Census } \\
\text { databases. }\end{array}$ & $\begin{array}{l}\text { Full-time } \\
\text { employment } \\
\text { increases clinic } \\
\text { productivity } \\
\text { depending on } \\
\text { clinic size }\end{array}$ & $\begin{array}{l}\text { Focused on } \\
\text { RHC } \\
\text { Survey done in } \\
\text { the US, may } \\
\text { not be } \\
\text { representative } \\
\text { of Ontario NPs }\end{array}$ \\
\hline Rich (2005) & $\begin{array}{l}\text { This study } \\
\text { assessed } \\
\text { whether a } \\
\text { relationship } \\
\text { exists between }\end{array}$ & $\begin{array}{l}\text { Cross- } \\
\text { sectional } \\
\text { survey }\end{array}$ & $\begin{array}{l}\text { Three } \\
\text { northeastern } \\
\text { universities with } \\
\text { NP programs }\end{array}$ & $\begin{array}{l}\text {-Prior nursing } \\
\text { experience } \\
\text {-NP education }\end{array}$ & $\begin{array}{l}\text { Researcher } \\
\text { developed tool-- } \\
\text { the Nurse } \\
\text { Practitioner } \\
\text { Demographic }\end{array}$ & $\begin{array}{l}\text { Response rate } \\
21 \% \\
\text { There is a } \\
\text { negative }\end{array}$ & $\begin{array}{l}\text { Study done in } \\
\text { the US, may } \\
\text { not be } \\
\text { representative } \\
\text { of Ontario NPs }\end{array}$ \\
\hline
\end{tabular}




\begin{tabular}{|c|c|c|c|c|c|c|c|}
\hline Source & Purpose & Design & Sample & Concepts & Instruments & Results & Comments \\
\hline & $\begin{array}{l}\text { duration of } \\
\text { prior RN } \\
\text { experience and } \\
\text { NP clinical } \\
\text { skills } \\
\text { competence in } \\
\text { professional } \\
\text { practice. }\end{array}$ & & $\begin{array}{l}\text { Surveys mailed to } \\
710 \text { NP alumni } \\
\text { United states } \\
\text { study }\end{array}$ & & $\begin{array}{l}\text { Tool (NPDT) } \\
\text { The Nurse } \\
\text { Practitioner } \\
\text { Skills Inventory } \\
\text { (NPSI) }\end{array}$ & $\begin{array}{l}\text { correlation } \\
\text { between years of } \\
\text { experience as a } \\
\text { registered nurse } \\
\text { (RN) and NP } \\
\text { clinical practice } \\
\text { skills }\end{array}$ & \\
\hline $\begin{array}{l}\text { Sangster- } \\
\text { Gormley et } \\
\text { al. (2012) }\end{array}$ & $\begin{array}{l}\text { To better } \\
\text { understand how } \\
\text { NPs in British } \\
\text { Columbia (BC) } \\
\text { are practicing } \\
\text { from Sept } 2011 \text { - } \\
\text { January 2012 }\end{array}$ & $\begin{array}{l}\text { Cross- } \\
\text { sectional } \\
\text { survey } \\
\text { design }\end{array}$ & $\begin{array}{l}37 \text { NPs returned } \\
\text { the survey } \\
\text { British Columbia } \\
\text { study }\end{array}$ & $\begin{array}{l}\text { NP education } \\
\text { and prior } \\
\text { nursing } \\
\text { experience } \\
\text { NP employment } \\
\text { status }\end{array}$ & Survey & $\begin{array}{l}\text {-NPs have a } \\
\text { master's degree } \\
\text { with the NP } \\
\text { certification } \\
-68 \% \text { of NPs are } \\
\text { full-time, } 26 \% \\
\text { part-time }\end{array}$ & $\begin{array}{l}\text { BC based } \\
\text { study may not } \\
\text { be } \\
\text { representative } \\
\text { of Ontario } \\
\text { PHC and NP } \\
\text { practice }\end{array}$ \\
\hline $\begin{array}{l}\text { Sloan, Pong, } \\
\text { Rukholm, \& } \\
\text { Caty (2006) }\end{array}$ & $\begin{array}{l}\text { To conduct a } \\
\text { survey of all } \\
\text { PHC NPs and } \\
\text { ACNPs, in } \\
\text { order to } \\
\text { describe NPs in } \\
\text { Ontario with } \\
\text { respect to their } \\
\text { demographic } \\
\text { characteristics, } \\
\text { geographic } \\
\text { distribution, } \\
\text { employment } \\
\text { trends and } \\
\text { practice profiles }\end{array}$ & $\begin{array}{l}\text { Cross- } \\
\text { sectional } \\
\text { survey }\end{array}$ & $\begin{array}{l}\text { All NPs } \\
\text { practicing in } \\
\text { Ontario in } 2004 \\
\text { Survey mailed to } \\
621 \text { NPs }\end{array}$ & $\begin{array}{l}\text { NP role clarity } \\
\text { NP employment } \\
\text { status }\end{array}$ & $\begin{array}{l}\text { Questionnaire } \\
\text { for both PHC } \\
\text { NPs and ACNPs } \\
\text { was developed } \\
\text { in consultation } \\
\text { with the } \\
\text { Advisory } \\
\text { Committee for } \\
\text { the NPAO } \\
\text { Electronic } \\
\text { Registry Project } \\
\text { and with the } \\
\text { Project Manager } \\
\text { Pilot tested for } \\
\text { content validity }\end{array}$ & $\begin{array}{l}\text { Response rate } \\
60 \% \\
\text { Lack of } \\
\text { interdisciplinary } \\
\text { education on NP } \\
\text { scope of practice } \\
75 \% \text { of NPs were } \\
\text { employed full- } \\
\text { time, } 21 \% \text { were } \\
\text { part-time, and } 2 \% \\
\text { were casual }\end{array}$ & $\begin{array}{l}\text { Results } \\
\text { represent acute } \\
\text { care and PHC } \\
\text { NPs }\end{array}$ \\
\hline $\begin{array}{l}\text { van Soeren et } \\
\text { al. }(2009)\end{array}$ & $\begin{array}{l}\text { To examine } \\
\text { NP-PHC } \\
\text { demographics, }\end{array}$ & $\begin{array}{l}\text { Cross- } \\
\text { sectional } \\
\text { survey } \\
\end{array}$ & $\begin{array}{l}\text { Surveys sent to } \\
589 \text { NPs in } \\
\text { Ontario }\end{array}$ & $\begin{array}{l}\text { Years of } \\
\text { experience } \\
\text { practicing as a }\end{array}$ & $\begin{array}{l}\text { Survey designed } \\
\text { by NPAO } \\
\text { Electronic } \\
\end{array}$ & $\begin{array}{l}\text { Response rate was } \\
60 \%\end{array}$ & $\begin{array}{l}\text { Results } \\
\text { represent acute } \\
\text { care and } \mathrm{PHC} \\
\end{array}$ \\
\hline
\end{tabular}




\begin{tabular}{|c|c|c|c|c|c|c|c|}
\hline Source & Purpose & Design & Sample & Concepts & Instruments & Results & Comments \\
\hline & $\begin{array}{l}\text { geographic } \\
\text { distribution, } \\
\text { employment } \\
\text { trends, and } \\
\text { practice profiles }\end{array}$ & & & $\begin{array}{l}\text { NP } \\
\text { NP education } \\
\text { NP role clarity }\end{array}$ & $\begin{array}{l}\text { Registry } \\
\text { Advisory } \\
\text { Committee and } \\
\text { the CRaNHR } \\
\text { team } \\
\text { Survey pilot } \\
\text { tested with } 13 \\
\text { NPs for content } \\
\text { validity }\end{array}$ & $\begin{array}{l}87 \% \text { of NPs } \\
\text { reported } \\
\text { completing the } \\
\text { PHC NP } \\
\text { certification } \\
\text { process } \\
\text { The majority of } \\
\text { participants had } \\
\text { approximately } \\
\text { three years } \\
\text { experience as a } \\
\text { NP } \\
\text { Lack of } \\
\text { interdisciplinary } \\
\text { education on NP } \\
\text { scope of practice }\end{array}$ & NPs \\
\hline $\begin{array}{l}\text { Venning et } \\
\text { al. }(2000)\end{array}$ & $\begin{array}{l}\text { To compare the } \\
\text { cost } \\
\text { effectiveness of } \\
\text { general } \\
\text { practitioners } \\
\text { and nurse } \\
\text { practitioners as } \\
\text { first point of } \\
\text { contact in } \\
\text { primary care. }\end{array}$ & $\begin{array}{l}\text { Multi-centre } \\
\text { RCT }\end{array}$ & $\begin{array}{l}20 \text { general } \\
\text { practices in } \\
\text { England and } \\
\text { Wales } \\
1292 \text { patients } \\
\text { (651 general } \\
\text { practitioner visits } \\
\text { and } 641 \mathrm{NP} \\
\text { visits) }\end{array}$ & $\begin{array}{l}\text { Years of } \\
\text { experience }\end{array}$ & $\begin{array}{l}\text { Consultation } \\
\text { process (length } \\
\text { of consultation, } \\
\text { examinations, } \\
\text { prescriptions, } \\
\text { referrals), } \\
\text { patient } \\
\text { satisfaction, } \\
\text { health status, } \\
\text { return clinic } \\
\text { visits over two } \\
\text { weeks, and costs }\end{array}$ & $\begin{array}{l}\text { Novice NPs have } \\
\text { similar patient } \\
\text { outcomes; } \\
\text { however, are more } \\
\text { likely to ask } \\
\text { patients to return } \\
\text { and take longer } \\
\text { doing consults }\end{array}$ & $\begin{array}{l}\text { United } \\
\text { Kingdom } \\
\text { study } \\
\text { Strong focus } \\
\text { on NP cost- } \\
\text { effectiveness }\end{array}$ \\
\hline VHA (2009) & $\begin{array}{l}\text { Establishes the } \\
\text { guidelines for } \\
\text { use of PCMM } \\
\text { at all VHA } \\
\text { Primary Care }\end{array}$ & & $\begin{array}{l}\text { United States } \\
\text { report }\end{array}$ & $\begin{array}{l}\text { Years of } \\
\text { experience } \\
\text { practicing as a } \\
\text { NP in a } \\
\text { particular PHC }\end{array}$ & & $\begin{array}{l}\text { It may take } 12 \text { to } \\
15 \text { months to } \\
\text { build a panel of } \\
\text { patients; the } \\
\text { provider operates }\end{array}$ & $\begin{array}{l}\text { US report and } \\
\text { data, may not } \\
\text { be } \\
\text { representative } \\
\text { of Ontario NPs }\end{array}$ \\
\hline
\end{tabular}




\begin{tabular}{|c|c|c|c|c|c|c|c|}
\hline Source & Purpose & Design & Sample & Concepts & Instruments & Results & Comments \\
\hline & sites of care. & & & site & & $\begin{array}{l}\text { at } 50 \% \text { of a fully- } \\
\text { established } \\
\text { provider for the } \\
\text { first six months, } \\
\text { and increases to } \\
100 \% \text { at } 12 \\
\text { months }\end{array}$ & \\
\hline $\begin{array}{l}\text { Waszynski, } \\
\text { Murakami, \& } \\
\text { Lewis (2000) }\end{array}$ & $\begin{array}{l}\text { This article } \\
\text { discusses the } \\
\text { results of a } \\
\text { group of } \\
\text { advanced } \\
\text { practice nurses } \\
\text { who designed } \\
\text { and } \\
\text { implemented a } \\
\text { care } \\
\text { coordination } \\
\text { model for high } \\
\text { risk older adults }\end{array}$ & $\begin{array}{l}\text { Model } \\
\text { development } \\
\text { and } \\
\text { implementati } \\
\text { on }\end{array}$ & $\begin{array}{l}\text { United States } \\
\text { study }\end{array}$ & $\begin{array}{l}\text { NP role clarity } \\
\text { NP education }\end{array}$ & $\begin{array}{l}\text { Process } \\
\text { outcomes and } \\
\text { challenges } \\
\text { assessed }\end{array}$ & $\begin{array}{l}\text { Lack of } \\
\text { interdisciplinary } \\
\text { education on NP } \\
\text { scope of practice } \\
\text { Master's level } \\
\text { education strives } \\
\text { to develop and } \\
\text { refine these } \\
\text { clinical, } \\
\text { interpersonal and } \\
\text { organizational } \\
\text { facets of role } \\
\text { development }\end{array}$ & $\begin{array}{l}\text { US report and } \\
\text { data, may not } \\
\text { be } \\
\text { representative } \\
\text { of Ontario NPs }\end{array}$ \\
\hline $\begin{array}{l}\text { Way, Jones, } \\
\text { Baskerville } \\
\text { \& Busing } \\
(2001)\end{array}$ & $\begin{array}{l}\text { To determine } \\
\text { what services } \\
\text { are provided by } \\
\text { NPs and family } \\
\text { physicians (FP) } \\
\text { in a rural } \\
\text { practice settings }\end{array}$ & Case study & $\begin{array}{l}2 \text { NPs, } 4 \text { FPs } \\
400 \text { patient } \\
\text { encounters } \\
\text { Ontario study }\end{array}$ & NP role clarity & $\begin{array}{l}\text { Data analyzed } \\
\text { from } 122 \mathrm{NP} \\
\text { patient } \\
\text { encounters and } \\
278 \text { FP patient } \\
\text { encounters to } \\
\text { determine } \\
\text { frequent } \\
\text { activities and } \\
\text { practice patterns }\end{array}$ & $\begin{array}{l}\text { Lack of } \\
\text { interdisciplinary } \\
\text { education on NP } \\
\text { scope of practice }\end{array}$ & $\begin{array}{l}\text { Physician } \\
\text { focused } \\
\text { Focus on rural } \\
\text { NP/FP } \\
\text { activities that } \\
\text { may vary in } \\
\text { other settings }\end{array}$ \\
\hline
\end{tabular}




\section{Appendix D}

Summary of Literature Examining Organizational Factors

\begin{tabular}{|c|c|c|c|c|c|c|c|}
\hline Source & Purpose & Design & Sample & Concepts & Instruments & Results & Comments \\
\hline Abood (2005) & $\begin{array}{l}\text { The purpose of } \\
\text { this study was } \\
\text { to describe the } \\
\text { compensation } \\
\text { arrangements } \\
\text { experienced by } \\
\text { primary care } \\
\text { NPs in the } \\
\text { managed care } \\
\text { environment. }\end{array}$ & $\begin{array}{l}\text { Cross-sectional } \\
\text { survey with } \\
\text { qualitative } \\
\text { interviews }\end{array}$ & $\begin{array}{l}1000 \mathrm{NPs} \\
\text { mailed } \\
\text { United states } \\
\text { study }\end{array}$ & $\begin{array}{l}\text { NP has own } \\
\text { patient panel } \\
\text { Personnel } \\
\text { support }\end{array}$ & Survey & $\begin{array}{l}\text {-Response rate } \\
\text { of } 38 \% \\
\text {-NPs who had } \\
\text { their own } \\
\text { patients as a } \\
\text { primary care } \\
\text { provider had } \\
\text { greater clinical } \\
\text { decision making } \\
\text { authority and } \\
\text { increased } \\
\text { productivity } \\
\text {-NPs have to do } \\
\text { everything- } \\
\text { NP, RN, } \\
\text { scheduler, set up } \\
\text { rooms, etc. }\end{array}$ & $\begin{array}{l}\text { Study done in } \\
\text { the US, may } \\
\text { not be } \\
\text { representative } \\
\text { of Ontario NPs }\end{array}$ \\
\hline $\begin{array}{l}\text { Altschuler, } \\
\text { Margolius, } \\
\text { Bodenheimer, \& } \\
\text { Grumbach } \\
\text { (2012) }\end{array}$ & $\begin{array}{l}\text { Estimate } \\
\text { primary care } \\
\text { panel sizes } \\
\text { under different } \\
\text { models of task } \\
\text { delegation to } \\
\text { non-physician } \\
\text { members of the } \\
\text { primary care } \\
\text { team }\end{array}$ & $\begin{array}{l}\text { Secondary data } \\
\text { analysis }\end{array}$ & $\begin{array}{l}\text { United states } \\
\text { study }\end{array}$ & $\begin{array}{l}\text { Inter- } \\
\text { disciplinary } \\
\text { team }\end{array}$ & $\begin{array}{l}\text { Used three } \\
\text { companion studies } \\
\text { and data from the } \\
\text { National } \\
\text { Ambulatory care } \\
\text { survey }\end{array}$ & $\begin{array}{l}77 \% \text { of } \\
\text { preventative } \\
\text { services and } \\
47 \% \text { of chronic } \\
\text { care can be } \\
\text { delegated to a } \\
\text { NP to increase a } \\
\text { physician's } \\
\text { patient panel } \\
\text { size }\end{array}$ & $\begin{array}{l}\text { US data, may } \\
\text { not be } \\
\text { representative } \\
\text { of Ontario NPs } \\
\text { Focus on } \\
\text { physician } \\
\text { patient panel } \\
\text { size }\end{array}$ \\
\hline $\begin{array}{l}\text { Buerhaus, } \\
\text { DesRoches, } \\
\text { Dittus, \& } \\
\text { Donelan (2015) }\end{array}$ & $\begin{array}{l}\text { The purpose of } \\
\text { this study was } \\
\text { to identify } \\
\text { demographic }\end{array}$ & $\begin{array}{l}\text { Cross-sectional } \\
\text { survey }\end{array}$ & $\begin{array}{l}\text { From } \\
\text { November 23, } \\
\text { 2011, to April } \\
9,2012 \text {, we }\end{array}$ & $\begin{array}{l}\text { Practice size, } \\
\text { type, and } \\
\text { location }\end{array}$ & $\begin{array}{l}\text { Questionnaire } \\
\text { domains included } \\
\text { compensation and } \\
\text { billing practices; }\end{array}$ & $\begin{array}{l}\text {-PCNPs are } \\
\text { more likely than } \\
\text { PCMDs to } \\
\text { practice in urban }\end{array}$ & $\begin{array}{l}\text { Study done in } \\
\text { the US, may } \\
\text { not be } \\
\text { representative }\end{array}$ \\
\hline
\end{tabular}




\begin{tabular}{|c|c|c|c|c|c|c|c|}
\hline Source & Purpose & Design & Sample & Concepts & Instruments & Results & Comments \\
\hline & $\begin{array}{l}\text { and practice } \\
\text { characteristics } \\
\text { of PCNPs and } \\
\text { compare these } \\
\text { characteristics } \\
\text { with primary } \\
\text { care physicians } \\
\text { (PCMDs) }\end{array}$ & & $\begin{array}{l}\text { conducted a } \\
\text { national postal } \\
\text { mail survey of } \\
972 \text { clinicians } \\
\text { (467 PCNPs } \\
\text { and } 505 \\
\text { PCMDs) } \\
\text { United states } \\
\text { study }\end{array}$ & $\begin{array}{l}\text { The inter- } \\
\text { disciplinary } \\
\text { team and NP- } \\
\text { physician } \\
\text { collaboration }\end{array}$ & $\begin{array}{l}\text { characteristics of } \\
\text { patients treated; } \\
\text { PCNPs' use of } \\
\text { their own National } \\
\text { Provider } \\
\text { Identification } \\
\text { number to bill } \\
\text { services; how } \\
\text { PCNPs spend their } \\
\text { time; clinical and } \\
\text { nonclinical } \\
\text { activities } \\
\text { performed; and } \\
\text { whether PCNPs } \\
\text { have privileges to } \\
\text { admit, round on } \\
\text { (i.e., oversee the } \\
\text { care provided to) } \\
\text { patients, and write } \\
\text { orders } \\
\text { independently of } \\
\text { physicians. The } \\
\text { response rate was } \\
61.2 \% \text {. }\end{array}$ & $\begin{array}{l}\text { and rural areas } \\
\text { and provide care } \\
\text { in a wider range } \\
\text { of community } \\
\text { settings } \\
\text {-The majority of } \\
\text { both clinicians } \\
\text { believe that } \\
\text { increasing the } \\
\text { supply of } \\
\text { PCNPs will } \\
\text { result in greater } \\
\text { collaboration } \\
\text { and team } \\
\text { practice }\end{array}$ & of Ontario NPs \\
\hline $\begin{array}{l}\text { Carryer \& } \\
\text { Yarwood (2015) }\end{array}$ & $\begin{array}{l}\text { Discussion } \\
\text { paper around } \\
\text { the NP role in } \\
\text { New Zealand } \\
\text { and the ability } \\
\text { for the role to } \\
\text { transform PHC } \\
\text { services }\end{array}$ & & $\begin{array}{l}\text { Examine the } \\
\text { following } \\
\text { studies: } \\
\text { Carryer, } \\
\text { Budge, } \\
\text { Hansen, \& } \\
\text { Gibbs, 2010; } \\
\text { Carryer, } \\
\text { Budge, } \\
\text { Hansen, \& } \\
\text { Gibbs, 2010; }\end{array}$ & $\begin{array}{l}\text { NP } \\
\text { autonomy }\end{array}$ & & $\begin{array}{l}\text { NPs have the } \\
\text { potential to } \\
\text { improve patient } \\
\text { safety and } \\
\text { improve patient } \\
\text { outcomes by } \\
\text { maximizing } \\
\text { their scope }\end{array}$ & $\begin{array}{l}\text { Focused on } \\
\text { NPs in New } \\
\text { Zealand; thus } \\
\text { may not be } \\
\text { representative } \\
\text { of Ontario NPs }\end{array}$ \\
\hline
\end{tabular}




\begin{tabular}{|c|c|c|c|c|c|c|c|}
\hline Source & Purpose & Design & Sample & Concepts & Instruments & Results & Comments \\
\hline & & & $\begin{array}{l}\text { Carryer, } \\
\text { Doolan-Noble, } \\
\text { Gauld, \& } \\
\text { Budge, 2014; } \\
\text { Carryer, Snell, } \\
\text { Hunt, Perry, \& } \\
\text { Blakey, 2008; } \\
\text { Yarwood, } \\
2008 \\
\text { New Zealand } \\
\text { study }\end{array}$ & & & & \\
\hline $\begin{array}{l}\text { Chumbler et al. } \\
\text { (2000) }\end{array}$ & $\begin{array}{l}\text { Determine if } \\
\text { NPs with } \\
\text { greater clinical } \\
\text { decision } \\
\text { making will } \\
\text { have greater } \\
\text { outpatient } \\
\text { clinical } \\
\text { productivity }\end{array}$ & $\begin{array}{l}\text { Cross-sectional } \\
\text { survey }\end{array}$ & $\begin{array}{l}628 \text { NPs } \\
\text { United states } \\
\text { study }\end{array}$ & $\begin{array}{l}\text { Indirect } \\
\text { patient care } \\
\text { activities } \\
\text { NP has own } \\
\text { patient panel } \\
\text { NP level of } \\
\text { autonomy } \\
\text { Inter- } \\
\text { disciplinary } \\
\text { team }\end{array}$ & Survey & $\begin{array}{l}\text {-Time spent in } \\
\text { NP activities } \\
\text { was correlated } \\
\text { to clinical } \\
\text { decision-making } \\
\text { autonomy } \\
\text { - NPs who had } \\
\text { their own } \\
\text { patients as a } \\
\text { primary care } \\
\text { provider had } \\
\text { greater clinical } \\
\text { decision making } \\
\text { authority } \\
\text { - NP clinical } \\
\text { productivity } \\
\text { increases as NP } \\
\text { decision-making } \\
\text { authority } \\
\text { increases } \\
\text { - NPs who } \\
\text { practiced in } \\
\text { multispecialty }\end{array}$ & $\begin{array}{l}\text { Study done in } \\
\text { the US, may } \\
\text { not be } \\
\text { representative } \\
\text { of Ontario NPs }\end{array}$ \\
\hline
\end{tabular}




\begin{tabular}{|c|c|c|c|c|c|c|c|}
\hline Source & Purpose & Design & Sample & Concepts & Instruments & Results & Comments \\
\hline & & & & & & $\begin{array}{l}\text { practice versus a } \\
\text { single-specialty } \\
\text { practice had } \\
\text { greater levels of } \\
\text { clinical } \\
\text { decision-making }\end{array}$ & \\
\hline $\begin{array}{l}\text { Dahrouge et al. } \\
\text { (2014) }\end{array}$ & $\begin{array}{l}\text { To describe the } \\
\text { models of } \\
\text { practice used by } \\
\text { nurse } \\
\text { practitioners } \\
\text { (NPs) and FPs } \\
\text { in community } \\
\text { health centres } \\
\text { (CHCs), and to } \\
\text { examine the } \\
\text { roles of NPs } \\
\text { and FPs in these } \\
\text { models. }\end{array}$ & $\begin{array}{l}\text { Cross-sectional } \\
\text { survey }\end{array}$ & $\begin{array}{l}21 \text { CHCs } \\
\text { A total of } 44 \\
849 \text { patients, } \\
53 \text { full-time } \\
\text { equivalent } \\
\text { FPs, and } 41 \\
\text { full-time } \\
\text { equivalent } \\
\text { NPs. } \\
\text { Ontario study }\end{array}$ & $\begin{array}{l}\text { Direct patient } \\
\text { care activities } \\
\text { Personnel } \\
\text { support }\end{array}$ & $\begin{array}{l}\text { Organizational } \\
\text { survey completed } \\
\text { by managers of the } \\
\text { CHC sites, as well } \\
\text { as administrative } \\
\text { data on patient } \\
\text { sociodemographic } \\
\text { characteristics and } \\
\text { encounter } \\
\text { activities }\end{array}$ & $\begin{array}{l}\text { NPs and family } \\
\text { physicians in } \\
\text { CHCs spend a } \\
\text { similar amount } \\
\text { of time in direct } \\
\text { clinical care and } \\
\text { administration } \\
\text { tasks } \\
\text { Support staff } \\
\text { increase patient } \\
\text { panel size } \\
\text { Larger practices } \\
\text { can support } \\
\text { larger panel } \\
\text { sizes }\end{array}$ & $\begin{array}{l}\text { Focus on only } \\
\text { Ontario CHCs }\end{array}$ \\
\hline $\begin{array}{l}\text { Deshefy-Longhi, } \\
\text { Swartz, \& Grey } \\
\text { (2008) }\end{array}$ & $\begin{array}{l}\text { Characterize } \\
\text { NPs practice by } \\
\text { using reports of } \\
\text { patient } \\
\text { encounters to } \\
\text { more accurately } \\
\text { reflect practice } \\
\text { patterns than } \\
\text { has been } \\
\text { previously } \\
\text { performed }\end{array}$ & $\begin{array}{l}\text { Descriptive } \\
\text { study } \\
\text { Six month } \\
\text { study }\end{array}$ & $\begin{array}{l}54 \text { NPs from } \\
45 \text { different } \\
\text { practice sites } \\
\text { United states } \\
\text { study }\end{array}$ & $\begin{array}{l}\text { Direct patient } \\
\text { care activities }\end{array}$ & $\begin{array}{l}\text { Two part survey } \\
\text { included } \\
\text { demographic form } \\
\text { and practice form }\end{array}$ & $\begin{array}{l}\text {-NPs in PHC } \\
\text { spend } 45 \% \text { of } \\
\text { their patient } \\
\text { visits treating } \\
\text { acute illness and } \\
30 \% \text { of their } \\
\text { patient visits on } \\
\text { chronic illness } \\
\text {-Counseling of } \\
\text { some kind in } \\
84 \% \text { of all } \\
\text { patient visits } \\
\text { - General } \\
\text { medical exam, }\end{array}$ & $\begin{array}{l}\text { Study done in } \\
\text { the US, may } \\
\text { not be } \\
\text { representative } \\
\text { of Ontario NPs }\end{array}$ \\
\hline
\end{tabular}




\begin{tabular}{|c|c|c|c|c|c|c|c|}
\hline Source & Purpose & Design & Sample & Concepts & Instruments & Results & Comments \\
\hline & & & & & & $\begin{array}{l}\text { well-baby exam, } \\
\text { and cough are } \\
\text { the top three } \\
\text { visits patients }\end{array}$ & \\
\hline $\begin{array}{l}\text { DiCenso et al. } \\
(2010)\end{array}$ & $\begin{array}{l}\text { Describe the } \\
\text { integration of } \\
\text { NPs into two } \\
\text { PHC models: } \\
\text { fee-for service } \\
\text { practices and } \\
\text { NPLCs }\end{array}$ & & Ontario study & $\begin{array}{l}\text { Personnel } \\
\text { support } \\
\text { Practice size, } \\
\text { type, location }\end{array}$ & $\begin{array}{l}\text { Literature Review } \\
\text { Key informant } \\
\text { interviews }\end{array}$ & $\begin{array}{l}\text { Increased staff } \\
\text { support, } \\
\text { secretarial, } \\
\text { admin, and } \\
\text { housekeeping } \\
\text { increases clinic } \\
\text { productivity and } \\
\text { patient panel } \\
\text { size } \\
\text { Larger practices } \\
\text { can have more } \\
\text { exam rooms and } \\
\text { therefore larger } \\
\text { patient panels }\end{array}$ & $\begin{array}{l}\text { Focus on only } \\
\text { two PHC } \\
\text { models; } \\
\text { however, } \\
\text { provided } \\
\text { relevant PHC } \\
\text { data }\end{array}$ \\
\hline $\begin{array}{l}\text { DiCicco-Bloom } \\
\text { \& Cunningham } \\
(2015)\end{array}$ & $\begin{array}{l}\text { This qualitative } \\
\text { study explored } \\
\text { how patients are } \\
\text { assigned and } \\
\text { cared for by } \\
\text { NPs vs. } \\
\text { physicians and } \\
\text { how these } \\
\text { clinicians relate } \\
\text { to one another. } \\
\text { Additionally } \\
\text { how PCNPs } \\
\text { relate to } \\
\text { physicians } \\
\text { outside the } \\
\text { practice was } \\
\text { examined. }\end{array}$ & $\begin{array}{l}\text { Qualitative } \\
\text { Interviews with } \\
\text { content } \\
\text { analysis }\end{array}$ & $\begin{array}{l}1 \mathrm{NP} \text { and } 1 \\
\text { physician in } \\
10 \mathrm{PHC} \\
\text { practices } \\
\text { United states } \\
\text { study }\end{array}$ & $\begin{array}{l}\text { Inter- } \\
\text { disciplinary } \\
\text { team and NP } \\
\text { physician } \\
\text { collaboration }\end{array}$ & In depth interviews & $\begin{array}{l}\text {-Participating } \\
\text { NPs and } \\
\text { physicians have } \\
\text { highly } \\
\text { collaborative } \\
\text { relationships. } \\
\text { NPs often } \\
\text { function } \\
\text { independently, } \\
\text { engage in } \\
\text { reciprocal } \\
\text { consultations } \\
\text { with physicians, } \\
\text { and provide care } \\
\text { to highly } \\
\text { complex } \\
\text { patients. }\end{array}$ & $\begin{array}{l}\text { US study, thus } \\
\text { may not be } \\
\text { representative } \\
\text { of Ontario NPs }\end{array}$ \\
\hline
\end{tabular}




\begin{tabular}{|c|c|c|c|c|c|c|c|}
\hline Source & Purpose & Design & Sample & Concepts & Instruments & Results & Comments \\
\hline & & & & & & $\begin{array}{l}\text {-NP } \\
\text { relationships } \\
\text { with physicians } \\
\text { outside the } \\
\text { practice are } \\
\text { disruptive }\end{array}$ & \\
\hline $\begin{array}{l}\text { Dierick-van } \\
\text { Daele et al. } \\
\text { (2009) }\end{array}$ & $\begin{array}{l}\text { Evaluate } \\
\text { process and } \\
\text { outcomes of } \\
\text { care provided to } \\
\text { patients with } \\
\text { common } \\
\text { complaints by } \\
\text { general } \\
\text { practitioners or } \\
\text { specially } \\
\text { trained NPs as } \\
\text { first point of } \\
\text { contact }\end{array}$ & $\begin{array}{l}\text { Randomized } \\
\text { control trial }\end{array}$ & $\begin{array}{l}1501 \text { patients } \\
\text { in } 15 \text { general } \\
\text { practices were } \\
\text { randomly } \\
\text { assigned to a } \\
\text { general } \\
\text { practitioner or } \\
\text { a NP } \\
\text { Netherlands } \\
\text { study }\end{array}$ & $\begin{array}{l}\text { Inter- } \\
\text { disciplinary } \\
\text { team }\end{array}$ & $\begin{array}{l}\text { Questionnaires } \\
\text { Extracting medical } \\
\text { records from } \\
\text { practice computer } \\
\text { systems and } \\
\text { recording the } \\
\text { length of } \\
\text { consultations }\end{array}$ & $\begin{array}{l}\text { NPs can be a } \\
\text { substitute for } 70 \\
\text { to } 80 \% \text { of } \\
\text { general } \\
\text { practitioners } \\
\text { activity to } \\
\text { increase patient } \\
\text { panel size }\end{array}$ & $\begin{array}{l}\text { Dutch study } \\
\text { Focuses on } \\
\text { comparing } \\
\text { NPs to } \\
\text { physicians }\end{array}$ \\
\hline $\begin{array}{l}\text { Dierick-van } \\
\text { Daele et al. } \\
\text { (2011) }\end{array}$ & $\begin{array}{l}\text { Examines the } \\
\text { potential } \\
\text { economic } \\
\text { viability of } \\
\text { nurse } \\
\text { practitioner } \\
\text { employment in } \\
\text { Dutch general } \\
\text { practices. }\end{array}$ & $\begin{array}{l}\text { Descriptive/ } \\
\text { exploratory } \\
\text { study }\end{array}$ & $\begin{array}{l}\text { GPs } \\
\text { employing } \\
\text { NPs }(n=132) \\
\text { Health insurers } \\
(n=12) \\
\text { Netherlands } \\
\text { study }\end{array}$ & $\begin{array}{l}\text { Direct patient } \\
\text { care activities } \\
\text { Indirect } \\
\text { patient care } \\
\text { activities } \\
\text { Practice size } \\
\text { Inter- } \\
\text { disciplinary } \\
\text { team }\end{array}$ & $\begin{array}{l}\text { Two } \\
\text { questionnaires }\end{array}$ & $\begin{array}{l}\text {-NPs spend } 77 \% \\
\text { of their time in } \\
\text { direct care } \\
\text { substituted tasks } \\
\text { for family } \\
\text { physicians and } \\
23 \% \text { of their } \\
\text { time in } \\
\text { complementary } \\
\text { tasks which tend } \\
\text { to be indirect } \\
\text { patient care } \\
\text { activities } \\
\text {-Larger practice } \\
\text { is associated } \\
\text { with a larger }\end{array}$ & $\begin{array}{l}\text { Focused on } \\
\text { NP cost- } \\
\text { effectiveness } \\
\text { Dutch study }\end{array}$ \\
\hline
\end{tabular}




\begin{tabular}{|c|c|c|c|c|c|c|c|}
\hline Source & Purpose & Design & Sample & Concepts & Instruments & Results & Comments \\
\hline & & & & & & $\begin{array}{l}\text { number of NPs } \\
\text {-NPs can be a } \\
\text { substitute for } 70 \\
\text { to } 80 \% \text { of } \\
\text { general } \\
\text { practitioners } \\
\text { activity to } \\
\text { increase patient } \\
\text { panel size }\end{array}$ & \\
\hline $\begin{array}{l}\text { Donald et al. } \\
\text { (2010) }\end{array}$ & $\begin{array}{l}\text { To develop a } \\
\text { better } \\
\text { understanding } \\
\text { of advanced } \\
\text { practice nursing } \\
\text { roles, their } \\
\text { current use, and } \\
\text { the individual, } \\
\text { organizational } \\
\text { and health } \\
\text { system factors } \\
\text { that influence } \\
\text { their effective } \\
\text { development } \\
\text { and integration }\end{array}$ & $\begin{array}{l}\text { Literature } \\
\text { Review }\end{array}$ & $\begin{array}{l}468 \text { articles } \\
\text { Interviews ( } n \\
=62) \text { and } \\
\text { focus groups } \\
(n=4 \text { with a } \\
\text { total of } 19 \\
\text { NPs }) \\
\text { Ontario study }\end{array}$ & $\begin{array}{l}\text { Direct patient } \\
\text { care activities }\end{array}$ & $\begin{array}{l}\text { Literature review } \\
\text { and key informant } \\
\text { interviews }\end{array}$ & $\begin{array}{l}94 \% \text { of NPs } \\
\text { stated their main } \\
\text { responsibility } \\
\text { was direct } \\
\text { patient care }\end{array}$ & $\begin{array}{l}\text { Did not link } \\
\text { data to NP } \\
\text { patient panel } \\
\text { size }\end{array}$ \\
\hline $\begin{array}{l}\text { Duck et al. } \\
\text { (2001) }\end{array}$ & $\begin{array}{l}\text { Use a survey of } \\
\text { free standing } \\
\text { clinics and } \\
\text { hospital } \\
\text { outpatient } \\
\text { departments to } \\
\text { develop two } \\
\text { measures of } \\
\text { facility } \\
\text { productivity } \\
\text { and describe }\end{array}$ & $\begin{array}{l}\text { Cross-sectional } \\
\text { survey }\end{array}$ & $\begin{array}{l}226 \text { hospital- } \\
\text { sponsored and } \\
\text { free-standing } \\
\text { ambulatory } \\
\text { care sites or to } \\
\text { the sites' } \\
\text { sponsoring } \\
\text { organizations } \\
\text { in New York } \\
\text { City in late } \\
1997\end{array}$ & $\begin{array}{l}\text { Personnel } \\
\text { support } \\
\text { Size of } \\
\text { practice } \\
\text { Inter- } \\
\text { disciplinary } \\
\text { team } \\
\text { NP }\end{array}$ & $\begin{array}{l}1997 \text { New York } \\
\text { City Ambulatory } \\
\text { Care Provider } \\
\text { Survey } \\
\text { The survey } \\
\text { collected } \\
\text { information about } \\
\text { provider } \\
\text { characteristics and } \\
\text { auspices, scope } \\
\text { and volume of }\end{array}$ & $\begin{array}{l}\text {-Response rate } \\
\text { of } 80 \% \\
\text {-Increased staff } \\
\text { support, } \\
\text { secretarial, } \\
\text { admin, and } \\
\text { housekeeping } \\
\text { increases clinic } \\
\text { productivity and } \\
\text { patient panel } \\
\text { size }\end{array}$ & $\begin{array}{l}\text { Study done in } \\
\text { the US, may } \\
\text { not be } \\
\text { representative } \\
\text { of Ontario NPs }\end{array}$ \\
\hline
\end{tabular}




\begin{tabular}{|c|c|c|c|c|c|c|c|}
\hline Source & Purpose & Design & Sample & Concepts & Instruments & Results & Comments \\
\hline & $\begin{array}{l}\text { which inputs } \\
\text { and facility } \\
\text { characteristics } \\
\text { are associated } \\
\text { with } \\
\text { productivity }\end{array}$ & & $\begin{array}{l}\text { - Target } \\
\text { population } \\
\text { within } 226 \\
\text { hospitals- } \\
\text { physician } \\
\text { assistants, } \\
\text { NPs, certified } \\
\text { nurse } \\
\text { midwives, } \\
\text { medical } \\
\text { residents, and } \\
\text { nonresident } \\
\text { physicians }\end{array}$ & autonomy & $\begin{array}{l}\text { services provided, } \\
\text { staffing, managed } \\
\text { care arrangements, } \\
\text { and payer mix }\end{array}$ & $\begin{array}{l}\text {-More exam } \\
\text { rooms increases } \\
\text { provider } \\
\text { productivity } \\
\text {-Productivity } \\
\text { depends on staff } \\
\text { composition } \\
\text {-increased NP } \\
\text { autonomy } \\
\text { results in } \\
\text { increased clinic } \\
\text { productivity }\end{array}$ & \\
\hline $\begin{array}{l}\text { Grover \& } \\
\text { Niecko-Najjum } \\
\text { (2013) }\end{array}$ & $\begin{array}{l}\text { Explore } \\
\text { existing team- } \\
\text { based clinical } \\
\text { care delivery } \\
\text { models. The } \\
\text { authors describe } \\
\text { the barriers to } \\
\text { adopting these } \\
\text { models on a } \\
\text { large scale, } \\
\text { particularly the } \\
\text { regulatory, } \\
\text { financial, and } \\
\text { cultural factors } \\
\text { as well as scope } \\
\text { of practice } \\
\text { considerations } \\
\text { for non- } \\
\text { physician } \\
\text { providers. }\end{array}$ & $\begin{array}{l}\text { Literature } \\
\text { Review }\end{array}$ & $\begin{array}{l}\text { United states } \\
\text { study }\end{array}$ & $\begin{array}{l}\text { Inter- } \\
\text { disciplinary } \\
\text { team }\end{array}$ & & $\begin{array}{l}\text { Some physicians } \\
\text { continue to be } \\
\text { reluctant to give } \\
\text { autonomy, work } \\
\text { as a team } \\
\text { member, share } \\
\text { patient } \\
\text { responsibility, } \\
\text { office space, and } \\
\text { examination } \\
\text { rooms with non- } \\
\text { physician } \\
\text { providers such } \\
\text { as NPs } \\
\text { perpetuating the } \\
\text { barriers to team- } \\
\text { based primary } \\
\text { care models }\end{array}$ & $\begin{array}{l}\text { Study done in } \\
\text { the US may } \\
\text { not be } \\
\text { representative } \\
\text { of Ontario NPs }\end{array}$ \\
\hline $\begin{array}{l}\text { Guey-Chi Chen, } \\
\text { Mehrotra, and }\end{array}$ & $\begin{array}{l}\text { Discussion } \\
\text { paper how }\end{array}$ & & $\begin{array}{l}\text { United states } \\
\text { study }\end{array}$ & $\begin{array}{l}\text { NP direct } \\
\text { patient care }\end{array}$ & & $\begin{array}{l}\text { Group visits } \\
\text { decrease }\end{array}$ & $\begin{array}{l}\text { US report, } \\
\text { may not be }\end{array}$ \\
\hline
\end{tabular}




\begin{tabular}{|c|c|c|c|c|c|c|c|}
\hline Source & Purpose & Design & Sample & Concepts & Instruments & Results & Comments \\
\hline Auerbach (2014) & $\begin{array}{l}\text { effective } \\
\text { healthcare must } \\
\text { be balanced } \\
\text { with efficiency }\end{array}$ & & & $\begin{array}{l}\text { activities } \\
\text { NP level of } \\
\text { autonomy }\end{array}$ & & $\begin{array}{l}\text { provider } \\
\text { backlog, lower } \\
\text { costs, provide } \\
\text { timely } \\
\text { appointments, } \\
\text { improve patient } \\
\text { satisfaction, and } \\
\text { increase } \\
\text { effectiveness of } \\
\text { chronic illness } \\
\text { management. } \\
\text { Email and tele- } \\
\text { health had } \\
\text { similar positive } \\
\text { impacts } \\
\text { Greater NP } \\
\text { autonomy } \\
\text { increases clinic } \\
\text { productivity }\end{array}$ & $\begin{array}{l}\text { representative } \\
\text { of Ontario NPs }\end{array}$ \\
\hline $\begin{array}{l}\text { Haber et al. } \\
(2009)\end{array}$ & $\begin{array}{l}\text { Describes the } \\
\text { development of } \\
\text { the NP- } \\
\text { managed } \\
\text { faculty practice } \\
\text { model } \\
\text { development } \\
\text { between the } \\
\text { New York } \\
\text { University } \\
\text { college of } \\
\text { dentistry and } \\
\text { nursing to } \\
\text { provide } \\
\text { increased } \\
\text { access to PHC }\end{array}$ & Case study & $\begin{array}{l}18 \text { months } \\
510 \text { patients, } \\
210 \text { were } \\
\text { referrals made } \\
\text { from the } \\
\text { dental school } \\
\text { United states } \\
\text { study }\end{array}$ & $\begin{array}{l}\text { Indirect } \\
\text { patient care } \\
\text { activities }\end{array}$ & $\begin{array}{l}\text { Needs assessment } \\
\text { survey } \\
\text { Patient satisfaction } \\
\text { survey }\end{array}$ & $\begin{array}{l}\text {-NPs had to } \\
\text { network within } \\
\text { the dental school } \\
\text { to develop } \\
\text { relationships in } \\
\text { order to foster } \\
\text { this } \\
\text { collaboration } \\
\text {-NPs would } \\
\text { teach second } \\
\text { year dental } \\
\text { students to take } \\
\text { an accurate } \\
\text { blood pressure }\end{array}$ & $\begin{array}{l}\text { Study done in } \\
\text { the US, may } \\
\text { not be } \\
\text { representative } \\
\text { of Ontario NPs }\end{array}$ \\
\hline
\end{tabular}




\begin{tabular}{|c|c|c|c|c|c|c|c|}
\hline Source & Purpose & Design & Sample & Concepts & Instruments & Results & Comments \\
\hline Hayes (2007) & $\begin{array}{l}\text { To explore the } \\
\text { attitudes of } \\
\text { nurse } \\
\text { practitioners } \\
\text { (NPs) toward } \\
\text { managed care } \\
\text { and to identify } \\
\text { the sources of } \\
\text { negative } \\
\text { attitudes and the } \\
\text { factors that may } \\
\text { ameliorate } \\
\text { them. }\end{array}$ & $\begin{array}{l}\text { Narrative } \\
\text { inquiry }\end{array}$ & $\begin{array}{l}51 \text { NPs } \\
\text { United states } \\
\text { study }\end{array}$ & $\begin{array}{l}\text {-Personnel } \\
\text { support }\end{array}$ & $\begin{array}{l}\text { In-depth } \\
\text { interviews }\end{array}$ & $\begin{array}{l}\text { Increased staff } \\
\text { support, } \\
\text { secretarial, } \\
\text { admin, and } \\
\text { housekeeping } \\
\text { increases clinic } \\
\text { productivity and } \\
\text { patient panel } \\
\text { size }\end{array}$ & $\begin{array}{l}\text { Study done in } \\
\text { the US, may } \\
\text { not be } \\
\text { representative } \\
\text { of Ontario NPs }\end{array}$ \\
\hline Holcomb (2000) & $\begin{array}{l}\text { To identify the } \\
\text { activities of } \\
\text { NPs in PHC }\end{array}$ & $\begin{array}{l}\text { Cross-sectional } \\
\text { survey } \\
\text { Delphi method }\end{array}$ & $\begin{array}{l}131 \text { NPs } \\
\text { United states } \\
\text { study }\end{array}$ & $\begin{array}{l}\text { Direct patient } \\
\text { care activities } \\
\text { Indirect } \\
\text { patient care } \\
\text { activities }\end{array}$ & $\begin{array}{l}\text { Investigator } \\
\text { developed tools } \\
\text { 1) Survey tool- } \\
\text { consisting of a list } \\
\text { of activities } \\
\text { 2) Demographic } \\
\text { information for } \\
\text { NPs }\end{array}$ & $\begin{array}{l}-83 \text { core } \\
\text { activities that } \\
\text { NPs participate } \\
\text { in and } 90 \% \text { of } \\
\text { the core } \\
\text { activities } \\
\text { involve direct } \\
\text { care of their } \\
\text { patients } \\
\text {-The age of the } \\
\text { NP, the race of } \\
\text { the majority of } \\
\text { the patients, and } \\
\text { the community } \\
\text { size and practice } \\
\text { setting predicted } \\
\text { how much time } \\
\text { a NP was } \\
\text { completing } \\
\text { community } \\
\text { involvement } \\
\text { work and }\end{array}$ & $\begin{array}{l}\text { Study done in } \\
\text { the US, may } \\
\text { not be } \\
\text { representative } \\
\text { of Ontario NPs }\end{array}$ \\
\hline
\end{tabular}




\begin{tabular}{|c|c|c|c|c|c|c|c|}
\hline Source & Purpose & Design & Sample & Concepts & Instruments & Results & Comments \\
\hline & & & & & & $\begin{array}{l}\text { research } \\
\text { activities }\end{array}$ & \\
\hline $\begin{array}{l}\text { Huang et al. } \\
(2004)\end{array}$ & $\begin{array}{l}\text { To evaluate the } \\
\text { degree to which } \\
\text { Veterans } \\
\text { Affairs medical } \\
\text { centers } \\
\text { (VAMCs) } \\
\text { incorporated } \\
\text { NPs into PC } \\
\text { practices } \\
\text { between } 1996 \\
\text { and } 1999 \text {, and } \\
\text { to identify the } \\
\text { internal and } \\
\text { external } \\
\text { practice } \\
\text { environment } \\
\text { features } \\
\text { associated with } \\
\text { NP use. }\end{array}$ & $\begin{array}{l}\text { Cross-sectional } \\
\text { survey }\end{array}$ & $\begin{array}{l}131 \text { primary } \\
\text { care directors } \\
1996-1999 \\
\text { United states } \\
\text { study }\end{array}$ & $\begin{array}{l}\text { Practice } \\
\text { location }\end{array}$ & $\begin{array}{l}\text { Compared survey } \\
\text { results to } \\
\text { previously } \\
\text { published literature } \\
\text { and HRSA State } \\
\text { Health Workforce } \\
\text { Profiles }\end{array}$ & $\begin{array}{l}\text { Urban practices } \\
\text { have more NPs }\end{array}$ & $\begin{array}{l}\text { Focus only on } \\
\text { veterans } \\
\text { affairs } \\
\text { practices in } \\
\text { US }\end{array}$ \\
\hline $\begin{array}{l}\text { Humbert et al. } \\
\text { (2007) }\end{array}$ & $\begin{array}{l}\text { Evaluate the } \\
\text { efficacy of } \\
\text { integrating a NP } \\
\text { into PHC } \\
\text { settings with } \\
\text { interdisciplinary } \\
\text { teams and the } \\
\text { effect on } \\
\text { patients with } \\
\text { multiple } \\
\text { chronic } \\
\text { illnesses }\end{array}$ & $\begin{array}{l}\text { Randomized } \\
\text { control trial }\end{array}$ & $\begin{array}{l}3 \text { NPs each } \\
\text { had } 40 \text { patients } \\
\text { Ontario study }\end{array}$ & $\begin{array}{l}\text { Direct patient } \\
\text { care activities } \\
\text { Practice } \\
\text { location }\end{array}$ & $\begin{array}{l}\text { Home visit data } \\
\text { collection } \\
\text { Care planning }\end{array}$ & $\begin{array}{l}\text { Most of NP time } \\
\text { was spent on } \\
\text { care plan } \\
\text { development } \\
\text { and home visits } \\
\text { Travel time } \\
\text { needs to be } \\
\text { considered }\end{array}$ & $\begin{array}{l}\text { Focus on rural } \\
\text { PHC }\end{array}$ \\
\hline IBM Business & To examine & Cross-sectional & 476 NPs & Direct patient & Literature Review & -On average & Useful results; \\
\hline
\end{tabular}




\begin{tabular}{|c|c|c|c|c|c|c|c|}
\hline Source & Purpose & Design & Sample & Concepts & Instruments & Results & Comments \\
\hline $\begin{array}{l}\text { Consulting } \\
\text { Services (2003) }\end{array}$ & $\begin{array}{l}\text { barriers and } \\
\text { facilitators to } \\
\text { encourage } \\
\text { further } \\
\text { integration of } \\
\text { NPs into } \\
\text { specific practice } \\
\text { settings }\end{array}$ & survey design & $\begin{array}{l}500 \text { Physicians } \\
\text { Ontario report }\end{array}$ & $\begin{array}{l}\text { care activities } \\
\text { Indirect } \\
\text { patient care } \\
\text { activities } \\
\text { Practice type } \\
\text { NP level of } \\
\text { autonomy } \\
\text { Inter- } \\
\text { disciplinary } \\
\text { team }\end{array}$ & $\begin{array}{l}\text { NP Survey- } \\
\text { response rate 77\% } \\
\text { Physician Survey } \\
\text { Site visits } \\
\text { Patient survey } \\
\text { Population-based } \\
\text { survey }\end{array}$ & $\begin{array}{l}\text { PHC NPs spent } \\
73 \% \text { of their } \\
\text { time on clinical } \\
\text { activities } \\
\text {-NPs see the } \\
\text { requirement to } \\
\text { have physicians } \\
\text { sign referral } \\
\text { forms as time } \\
\text { consuming and } \\
\text { causes } \\
\text { fragmented care } \\
\text {-FHTs see more } \\
\text { patients then } \\
\text { CHCs per day } \\
-62 \% \text { of NPs } \\
\text { indicated that } \\
\text { autonomy was } \\
\text { one of the most } \\
\text { positive aspects } \\
\text { of their job. } \\
-75 \% \text { of NPs } \\
\text { indicated that } \\
\text { they delivered } \\
\text { care in the way } \\
\text { they liked } \\
\text {-On average } \\
\text { NPs reported } \\
\text { being satisfied } \\
\text { with open } \\
\text { communication } \\
\text { and amount of } \\
\text { collaboration } \\
\text { with physicians } \\
\text { regarding }\end{array}$ & $\begin{array}{l}\text { however, do } \\
\text { not relate } \\
\text { results } \\
\text { specifically to } \\
\text { NP patient } \\
\text { panel size }\end{array}$ \\
\hline
\end{tabular}




\begin{tabular}{|c|c|c|c|c|c|c|c|}
\hline Source & Purpose & Design & Sample & Concepts & Instruments & Results & Comments \\
\hline & & & & & & $\begin{array}{l}\text { patient care } \\
\text { decisions }\end{array}$ & \\
\hline Johnson (2005) & $\begin{array}{l}\text { To uncover } \\
\text { patterns across } \\
\text { (NP) } \\
\text { experiences that } \\
\text { contribute to } \\
\text { understanding } \\
\text { their } \\
\text { perceptions of } \\
\text { managed care, } \\
\text { how it affects } \\
\text { daily practice, } \\
\text { and how NPs } \\
\text { respond to a } \\
\text { changing } \\
\text { managed care } \\
\text { workplace }\end{array}$ & $\begin{array}{l}\text { Descriptive } \\
\text { Qualitative }\end{array}$ & $\begin{array}{l}14 \text { NPs with } \\
\text { three years } \\
\text { minimum } \\
\text { experience } \\
\text { New England } \\
\text { study }\end{array}$ & $\begin{array}{l}\mathrm{NP} \\
\text { autonomy }\end{array}$ & $\begin{array}{l}\text { In-depth } \\
\text { interviews }\end{array}$ & $\begin{array}{l}\text { NPs in specialty } \\
\text { practices are } \\
\text { often an added } \\
\text { value whereas in } \\
\text { primary care } \\
\text { practices NPs } \\
\text { are viewed as a } \\
\text { substitute for a } \\
\text { physician }\end{array}$ & $\begin{array}{l}\text { Study done in } \\
\text { New England, } \\
\text { may not be } \\
\text { representative } \\
\text { of Ontario NPs }\end{array}$ \\
\hline $\begin{array}{l}\text { Koren, Mian, \& } \\
\text { Rukholm } \\
(2010)\end{array}$ & $\begin{array}{l}\text { To determine } \\
\text { employment } \\
\text { and practice } \\
\text { characteristics } \\
\text { of PHC NPs } \\
\text { practicing in } \\
\text { Ontario }\end{array}$ & $\begin{array}{l}\text { Cross-sectional } \\
\text { survey }\end{array}$ & $\begin{array}{l}\text { PHC NPs } \\
\text { registered with } \\
\text { the College of } \\
\text { Nurses of } \\
\text { Ontario in } \\
2008 \\
\text { Survey sent to } \\
733 \text { PHC NPs } \\
\text { in Ontario }\end{array}$ & $\begin{array}{l}\text { Direct patient } \\
\text { care activities } \\
\text { Indirect } \\
\text { patient care } \\
\text { activities } \\
\mathrm{NP} \\
\text { autonomy } \\
\text { Inter- } \\
\text { disciplinary } \\
\text { team }\end{array}$ & $\begin{array}{l}\text {-Survey developed } \\
\text { by the CRaNHR } \\
\text { team in } \\
\text { consultation with } \\
\text { MOHLTC Nursing } \\
\text { Secretariat } \\
\text {-Pilot tested for } \\
\text { validity and } \\
\text { readability }\end{array}$ & $\begin{array}{l}\text {-Response rate } \\
\text { of } 68 \% \\
\text {-A third of NPs } \\
\text { time is spent on } \\
\text { treatment of } \\
\text { minor illnesses, } \\
25 \% \text { on chronic } \\
\text { disease } \\
\text { management, } \\
\text { and } 22 \% \text { on } \\
\text { health } \\
\text { promotion and } \\
\text { disease } \\
\text { prevention } \\
\text {-NPs working in } \\
\text { FHTs spent } \\
\text { more time in }\end{array}$ & $\begin{array}{l}\text { No focus on } \\
\text { NP patient } \\
\text { panel size }\end{array}$ \\
\hline
\end{tabular}




\begin{tabular}{|c|c|c|c|c|c|c|c|}
\hline Source & Purpose & Design & Sample & Concepts & Instruments & Results & Comments \\
\hline & & & & & & $\begin{array}{l}\text { direct patient } \\
\text { care compared } \\
\text { to other practice } \\
\text { settings } \\
\text { - NPs estimated } \\
\text { about } 5 \\
\text { telephone } \\
\text { consultations in } \\
\text { an average day. } \\
\text { As well, over } \\
13 \% \text { of their } \\
\text { sample had on- } \\
\text { call } \\
\text { responsibilities } \\
\text {-NPs in NPLC } \\
\text { spend more time } \\
\text { in administrative } \\
\text { duties and } \\
\text { travelling } \\
\text { between } \\
\text { multiple sites } \\
\text {-Rural NPs } \\
\text { work longer } \\
\text { hours, see more } \\
\text { patients, and } \\
\text { travel between } \\
\text { sites } \\
\text { - PHC NPS } \\
\text { provided care } \\
\text { for } 80 \% \text { of their } \\
\text { clients } \\
\text { autonomously or } \\
\text { with minimal } \\
\text { physician } \\
\text { consultation }\end{array}$ & \\
\hline
\end{tabular}




\begin{tabular}{|c|c|c|c|c|c|c|c|}
\hline Source & Purpose & Design & Sample & Concepts & Instruments & Results & Comments \\
\hline & & & & & & $\begin{array}{l}\text {-Physicians } \\
\text { outside of } \\
\text { practice often do } \\
\text { not accept } \\
\text { referrals from } \\
\text { NPs }\end{array}$ & \\
\hline $\begin{array}{l}\text { Kralewski, } \\
\text { Dowd, Curoe, } \\
\text { Savage, \& Tong } \\
\text { (2015) }\end{array}$ & $\begin{array}{l}\text { This study } \\
\text { aimed to } \\
\text { determine the } \\
\text { association of } \\
\text { NP care with } \\
\text { cost and quality } \\
\text { of care. }\end{array}$ & $\begin{array}{l}85 \text { primary } \\
\text { care medical } \\
\text { group practices } \\
\text { were matched } \\
\text { with } 315,000 \\
\text { Medicare } \\
\text { patients. Per } \\
\text { beneficiary per } \\
\text { year total costs } \\
\text { and quality of } \\
\text { care were } \\
\text { calculated from } \\
\text { Medicare } \\
\text { claims data. } \\
\text { Data were } \\
\text { analyzed using } \\
\text { multivariate } \\
\text { regression }\end{array}$ & $\begin{array}{l}85 \text { primary } \\
\text { care medical } \\
\text { group } \\
\text { practices were } \\
\text { matched with } \\
315,000 \\
\text { Medicare } \\
\text { patients } \\
\text { United states } \\
\text { study }\end{array}$ & $\begin{array}{l}\text { NP } \\
\text { autonomy }\end{array}$ & $\begin{array}{l}5 \text { quality of care } \\
\text { measures assessed }\end{array}$ & $\begin{array}{l}\text {-NPs who act in } \\
\text { a complimentary } \\
\text { rather than } \\
\text { substitutive role } \\
\text { can decrease } \\
\text { costs and } \\
\text { increase quality } \\
\text { of care } \\
\text {-Employing } 2 \\
\text { NPs per } \\
\text { physician } \\
\text { reduces costs } \\
\text { and increases } \\
\text { quality of care }\end{array}$ & $\begin{array}{l}\text { US study; thus } \\
\text { may not be } \\
\text { representative } \\
\text { of Ontario NPs }\end{array}$ \\
\hline $\begin{array}{l}\text { Liu \& D'Anno, } \\
\text { (2012) }\end{array}$ & $\begin{array}{l}\text { To develop } \\
\text { simple stylized } \\
\text { models for } \\
\text { evaluating the } \\
\text { productivity } \\
\text { and cost- } \\
\text { efficiencies of } \\
\text { different } \\
\text { practice models } \\
\text { to involve NPs } \\
\text { in primary care }\end{array}$ & $\begin{array}{l}\text { Literature } \\
\text { review }\end{array}$ & $\begin{array}{l}\text { United states } \\
\text { study }\end{array}$ & $\begin{array}{l}\text { Inter- } \\
\text { disciplinary } \\
\text { team }\end{array}$ & $\begin{array}{l}\text { Previous literature } \\
\text { and survey reports }\end{array}$ & $\begin{array}{l}\text {-NPs can be a } \\
\text { substitute for } 70 \\
\text { to } 80 \% \text { of } \\
\text { general } \\
\text { practitioners } \\
\text { activity to } \\
\text { increase patient } \\
\text { panel size } \\
\text {-When general } \\
\text { practitioners } \\
\text { have to }\end{array}$ & $\begin{array}{l}\text { Study done in } \\
\text { the US, may } \\
\text { not be } \\
\text { representative } \\
\text { of Ontario NPs }\end{array}$ \\
\hline
\end{tabular}




\begin{tabular}{|c|c|c|c|c|c|c|c|}
\hline Source & Purpose & Design & Sample & Concepts & Instruments & Results & Comments \\
\hline & & & & & & $\begin{array}{l}\text { supervise NPs } \\
\text { this decreases } \\
\text { productivity and } \\
\text { patient panel } \\
\text { size }\end{array}$ & \\
\hline Liu et al. (2014) & $\begin{array}{l}\text { The aim of this } \\
\text { article was to } \\
\text { compare the } \\
\text { productivity } \\
\text { and cost } \\
\text { efficiency of } \\
\text { NP utilization } \\
\text { models } \\
\text { implemented in } \\
\text { primary care } \\
\text { sites with and } \\
\text { without medical } \\
\text { assistant (MA) } \\
\text { support. }\end{array}$ & & $\begin{array}{l}\text { United states } \\
\text { study }\end{array}$ & $\begin{array}{l}\text { Personnel } \\
\text { support }\end{array}$ & $\begin{array}{l}\text { Queuing models } \\
\text { for these NP } \\
\text { utilization models, } \\
\text { of which the } \\
\text { parameters are } \\
\text { extracted from } \\
\text { literature or } \\
\text { government } \\
\text { reports }\end{array}$ & $\begin{array}{l}\text { Increased staff } \\
\text { support, } \\
\text { secretarial, } \\
\text { admin, and } \\
\text { housekeeping } \\
\text { increases clinic } \\
\text { productivity and } \\
\text { patient panel } \\
\text { size }\end{array}$ & $\begin{array}{l}\text { Study done in } \\
\text { the US, may } \\
\text { not be } \\
\text { representative } \\
\text { of Ontario NPs }\end{array}$ \\
\hline $\begin{array}{l}\text { Liu, Ozen, and } \\
\text { Balasubramanian } \\
\text { (2013) }\end{array}$ & $\begin{array}{l}\text { To develop } \\
\text { methods for } \\
\text { evaluating } \\
\text { access to care } \\
\text { and continuity } \\
\text { of care in } \\
\text { commonly-used } \\
\text { primary care } \\
\text { delivery models } \\
\text { adjusted for } \\
\text { case-mixes; and } \\
\text { to study how } \\
\text { these two } \\
\text { system } \\
\text { performance } \\
\text { measures }\end{array}$ & & $\begin{array}{l}\text { United states } \\
\text { study }\end{array}$ & $\begin{array}{l}\text { NP-physician } \\
\text { collaboration }\end{array}$ & $\begin{array}{l}\text { The access to care } \\
\text { is evaluated by the } \\
\text { patient } \\
\text { appointment delay, } \\
\text { and the continuity } \\
\text { of care is defined } \\
\text { as the percentage } \\
\text { of time a patient } \\
\text { seen by her own } \\
\text { primary care } \\
\text { provider. Queuing } \\
\text { analysis is } \\
\text { performed for } \\
\text { three commonly- } \\
\text { used primary care } \\
\text { practice designs, }\end{array}$ & $\begin{array}{l}\text { Partial pooling } \\
\text { model allows } \\
\text { provider } \\
\text { independence } \\
\text { and continuity } \\
\text { for patients }\end{array}$ & $\begin{array}{l}\text { Study done in } \\
\text { the US, may } \\
\text { not be } \\
\text { representative } \\
\text { of Ontario NPs }\end{array}$ \\
\hline
\end{tabular}




\begin{tabular}{|c|c|c|c|c|c|c|c|}
\hline Source & Purpose & Design & Sample & Concepts & Instruments & Results & Comments \\
\hline & $\begin{array}{l}\text { change under } \\
\text { panel (re)design } \\
\text { and provider } \\
\text { capacity } \\
\text { pooling (i.e., } \\
\text { patient sharing). }\end{array}$ & & & & $\begin{array}{l}\text { i.e., dedicated } \\
\text { service design, } \\
\text { partial pooling } \\
\text { design and } \\
\text { complete pooling } \\
\text { design. Model } \\
\text { parameters are } \\
\text { estimated using } \\
\text { data from Primary } \\
\text { Care Internal } \\
\text { Medicine Practice } \\
\text { at the Mayo Clinic } \\
\text { in Rochester, } \\
\text { Minnesota. }\end{array}$ & & \\
\hline Martin (2000) & $\begin{array}{l}\text { To determine } \\
\text { nurse } \\
\text { practitioners' } \\
\text { (NPs) practice } \\
\text { patterns and } \\
\text { willingness to } \\
\text { practice in } \\
\text { underserved } \\
\text { areas in both } \\
\text { rural and urban } \\
\text { settings in a } \\
\text { largely rural } \\
\text { state. }\end{array}$ & $\begin{array}{l}\text { Cross-sectional } \\
\text { survey }\end{array}$ & $\begin{array}{l}\text { Response rates } \\
\text { of } 76 \%(1,725 \\
\text { of } 2,280 \\
\text { surveys }) \\
\text { United states } \\
\text { study }\end{array}$ & $\begin{array}{l}\text { Practice } \\
\text { location } \\
\text { NP has own } \\
\text { patient panel }\end{array}$ & $\begin{array}{l}\text { A census of all } \\
\text { NPs holding a } \\
\text { Pennsylvania } \\
\text { license and } \\
\text { providing } \\
\text { addresses in } \\
\text { Pennsylvania or } \\
\text { one of the } \\
\text { contiguous states } \\
\text { was conducted in } \\
\text { 1996. The ZIP } \\
\text { codes of practice } \\
\text { sites were matched } \\
\text { with } 1990 \text { census } \\
\text { data. }\end{array}$ & $\begin{array}{l}\text {-Rural NPs } \\
\text { work longer } \\
\text { hours, see more } \\
\text { patients } \\
\text {-Urban practices } \\
\text { have more NPs } \\
\text {-Rural NPs are } \\
\text { more likely to } \\
\text { be the principle } \\
\text { care provider for } \\
\text { their patients } \\
\text { and see more } \\
\text { patients. }\end{array}$ & $\begin{array}{l}\text { Study done in } \\
\text { the US, may } \\
\text { not be } \\
\text { representative } \\
\text { of Ontario NPs }\end{array}$ \\
\hline $\begin{array}{l}\text { Martin-Misener } \\
\text { et al. (2010) }\end{array}$ & $\begin{array}{l}\text { To examine the } \\
\text { practice } \\
\text { patterns of NPs } \\
\text { in primary } \\
\text { health care in }\end{array}$ & $\begin{array}{l}\text { Cross-sectional } \\
\text { survey }\end{array}$ & $\begin{array}{l}\text { Survey sent to } \\
55 \text { NPs, } 39 \\
\text { responded } \\
\text { Nova Scotia } \\
\text { study }\end{array}$ & $\begin{array}{l}\text { Direct patient } \\
\text { care activities } \\
\text { Indirect care } \\
\text { activities }\end{array}$ & Survey & $\begin{array}{l}\text {-Response rate } \\
\text { was } 71 \% \\
-70 \% \text { in direct } \\
\text { patient care } \\
\text { activities } \\
\text { including, } 28 \%\end{array}$ & $\begin{array}{l}\text { Study specific } \\
\text { to Nova Scotia } \\
\text { NPs } \\
\text { Small sample }\end{array}$ \\
\hline
\end{tabular}




\begin{tabular}{|c|c|c|c|c|c|c|c|}
\hline Source & Purpose & Design & Sample & Concepts & Instruments & Results & Comments \\
\hline & Nova Scotia & & & & & $\begin{array}{l}\text { of time on } \\
\text { management } \\
\text { and monitoring } \\
\text { of chronic } \\
\text { illness, } 25 \% \text { on } \\
\text { wellness and } \\
\text { health } \\
\text { promotion, and } \\
20 \% \text { on episodic } \\
\text { care for minor } \\
\text { acute illness and } \\
\text { injury } \\
\text {-82\% of NPs } \\
\text { reported } \\
\text { performing } \\
\text { community } \\
\text { development } \\
\text { activities, which } \\
\text { included } \\
\text { planning and } \\
\text { implementing } \\
\text { health programs } \\
\text { and speaking to } \\
\text { communities } \\
\text { about health } \\
\text { related topics. } \\
\text { Many indicated } \\
\text { they had } \\
\text { administrative } \\
\text { responsibilities, } \\
\text { educated other } \\
\text { learners, and } \\
\text { had leadership } \\
\text { functions }\end{array}$ & $\begin{array}{l}\text { No time } \\
\text { allotted to } \\
\text { indirect NP } \\
\text { activities }\end{array}$ \\
\hline Mian et al. & To determine & Cross-sectional & NPs registered & Direct patient & -Survey developed & -Response rate & Focused on \\
\hline
\end{tabular}




\begin{tabular}{|c|c|c|c|c|c|c|c|}
\hline Source & Purpose & Design & Sample & Concepts & Instruments & Results & Comments \\
\hline (2012) & $\begin{array}{l}\text { employment } \\
\text { and practice } \\
\text { characteristics } \\
\text { of NPs } \\
\text { practicing in } \\
\text { Ontario }\end{array}$ & survey & $\begin{array}{l}\text { with the } \\
\text { College of } \\
\text { Nurses of } \\
\text { Ontario (CNO) } \\
\text { in } 2011 \\
\text { Survey sent to } \\
1,441 \text { NPs in } \\
\text { Ontario }\end{array}$ & $\begin{array}{l}\text { care activities } \\
\text { Indirect care } \\
\text { activities }\end{array}$ & $\begin{array}{l}\text { by the CRaNHR } \\
\text { team in } \\
\text { consultation with } \\
\text { MOHLTC Nursing } \\
\text { Secretariat }\end{array}$ & $\begin{array}{l}\text { of } 48 \% \\
\text {-On average, } \\
\text { respondents } \\
\text { spent } 72 \% \text { of } \\
\text { their time in a } \\
\text { typical month on } \\
\text { direct patient } \\
\text { care } \\
\text {-53\% on acute } \\
\text { and chronic } \\
\text { illness } \\
\text {-25\% on health } \\
\text { promotion and } \\
\text { disease } \\
\text { prevention } \\
\text {-NPs spend } 8 \% \\
\text { of their time in } \\
\text { an average } \\
\text { month on } \\
\text { education and } \\
\text { research }\end{array}$ & $\begin{array}{l}\text { PHC and acute } \\
\text { care NPs }\end{array}$ \\
\hline $\begin{array}{l}\text { Mian \& Koren, } \\
(2011)\end{array}$ & $\begin{array}{l}\text { Annual tracking } \\
\text { survey of PHC } \\
\text { NPs in Ontario }\end{array}$ & $\begin{array}{l}\text { Cross-sectional } \\
\text { survey }\end{array}$ & $\begin{array}{l}378 \text { NPs } \\
\text { responded to } \\
\text { the survey, } \\
\text { representing } \\
53 \% \text { of PHC } \\
\text { NPs in Ontario }\end{array}$ & $\begin{array}{l}\text { Direct patient } \\
\text { care activities } \\
\text { Indirect } \\
\text { patient care } \\
\text { activities }\end{array}$ & $\begin{array}{l}\text { Survey developed } \\
\text { by the CRaNHR } \\
\text { team in } \\
\text { consultation with } \\
\text { MOHLTC Nursing } \\
\text { Secretariat }\end{array}$ & $\begin{array}{l}\text {-Over a typical } \\
\text { month NPs } \\
\text { spent } 77 \% \text { of } \\
\text { their time in } \\
\text { direct patient } \\
\text { care activities } \\
\text {-During an } \\
\text { average week } \\
24.8 \% \text { spent on } \\
\text { chronic disease } \\
\text { management, } \\
30.6 \% \text { on minor } \\
\text { illnesses, } 22.2 \%\end{array}$ & $\begin{array}{l}\text { No focus on } \\
\text { impact to NP } \\
\text { patient panel } \\
\text { size }\end{array}$ \\
\hline
\end{tabular}




\begin{tabular}{|c|c|c|c|c|c|c|c|}
\hline Source & Purpose & Design & Sample & Concepts & Instruments & Results & Comments \\
\hline & & & & & & $\begin{array}{l}\text { on health } \\
\text { promotion and } \\
\text { disease } \\
\text { prevention, } \\
14.5 \% \text { on } \\
\text { counseling } \\
\text {-NPs spent } 6 \% \\
\text { of their time } \\
\text { teaching, } 5 \% \text { of } \\
\text { their time in } \\
\text { administration, } \\
\text { and } 2 \% \text { in } \\
\text { research } \\
\text { activities }\end{array}$ & \\
\hline $\begin{array}{l}\text { Miller et al. } \\
(2004)\end{array}$ & $\begin{array}{l}\text { To determine } \\
\text { the feasibility of } \\
\text { implementing a } \\
\text { group medical } \\
\text { visit model with } \\
\text { low-income } \\
\text { women in an } \\
\text { inner-city PHC } \\
\text { clinic setting }\end{array}$ & $\begin{array}{l}\text { Case study } \\
\text { design }\end{array}$ & $\begin{array}{l}\text { Six group } \\
\text { medical visit } \\
\text { sessions } \\
28 \text { patients } \\
\text { with at least } \\
\text { one chronic } \\
\text { illness } \\
\text { United states } \\
\text { study }\end{array}$ & $\begin{array}{l}\text { Inter- } \\
\text { disciplinary } \\
\text { team }\end{array}$ & $\begin{array}{l}\text { Open-ended } \\
\text { interviews } \\
\text { Chart reviews }\end{array}$ & $\begin{array}{l}\text { An example of } \\
\text { physicians and } \\
\text { NPs where they } \\
\text { worked in } \\
\text { equivalent roles } \\
\text { and had a strong } \\
\text { understanding of } \\
\text { their tasks } \\
\text { within a group } \\
\text { medical visit } \\
\text { and how this } \\
\text { increased } \\
\text { productivity and } \\
\text { produced } \\
\text { positive patient } \\
\text { health outcomes }\end{array}$ & $\begin{array}{l}\text { Study done in } \\
\text { the US, may } \\
\text { not be } \\
\text { representative } \\
\text { of Ontario NPs }\end{array}$ \\
\hline $\begin{array}{l}\text { Muldoon et al. } \\
\text { (2012) }\end{array}$ & $\begin{array}{l}\text { Take a look at } \\
\text { the relationship } \\
\text { of panel size to } \\
\text { quality and } \\
\text { outcomes of }\end{array}$ & $\begin{array}{l}\text { Literature } \\
\text { Review }\end{array}$ & Ontario study & $\begin{array}{l}\text { Personnel } \\
\text { support } \\
\text { Practice size }\end{array}$ & Literature Review & $\begin{array}{l}\text {-Increased staff } \\
\text { support, } \\
\text { secretarial, } \\
\text { admin, and } \\
\text { housekeeping }\end{array}$ & $\begin{array}{l}\text { Looks at panel } \\
\text { size with a } \\
\text { focus on } \\
\text { physicians }\end{array}$ \\
\hline
\end{tabular}




\begin{tabular}{|c|c|c|c|c|c|c|c|}
\hline Source & Purpose & Design & Sample & Concepts & Instruments & Results & Comments \\
\hline & $\begin{array}{l}\text { individuals and } \\
\text { the contextual } \\
\text { factors that } \\
\text { affect it }\end{array}$ & & & $\begin{array}{l}\text { Inter- } \\
\text { disciplinary } \\
\text { team }\end{array}$ & & $\begin{array}{l}\text { increases clinic } \\
\text { productivity and } \\
\text { patient panel } \\
\text { size } \\
\text {-More exam } \\
\text { rooms increases } \\
\text { panel size } \\
\text {-inter- } \\
\text { professional } \\
\text { teams allows for } \\
\text { physician } \\
\text { patient panel } \\
\text { size to increase }\end{array}$ & \\
\hline $\begin{array}{l}\text { Muldoon et al. } \\
\text { (2013) }\end{array}$ & $\begin{array}{l}\text { To determine if } \\
\text { patient poverty } \\
\text { is associated } \\
\text { with increased } \\
\text { workload for } \\
\text { primary care } \\
\text { providers } \\
(\mathrm{PCPs})\end{array}$ & $\begin{array}{l}\text { Linkage of } \\
\text { administrative } \\
\text { data } \\
\text { identifying } \\
\text { patient poverty } \\
\text { and } \\
\text { comorbidity } \\
\text { with survey } \\
\text { data about the } \\
\text { organizational } \\
\text { structure of } \\
\text { community } \\
\text { health centres } \\
\text { (CHCs). }\end{array}$ & $\begin{array}{l}64 \text { Ontario } \\
\text { CHCs }\end{array}$ & $\begin{array}{l}\text { NP has own } \\
\text { patient panel } \\
\text { size } \\
\text { Inter- } \\
\text { disciplinary } \\
\text { team }\end{array}$ & $\begin{array}{l}\text {-Administrative } \\
\text { data housed at the } \\
\text { Institute for } \\
\text { Clinical Evaluative } \\
\text { Sciences (ICES) } \\
\text {-Patient-level data } \\
\text { were extracted } \\
\text { from the CHCs' } \\
\text { electronic clinical } \\
\text { management } \\
\text { systems (CMSs) } \\
\text {-Organizational } \\
\text { survey }\end{array}$ & $\begin{array}{l}\text {-NPs are } \\
\text { principle } \\
\text { provider for } \\
22 \% \text { of patients } \\
\text { in CHCs } \\
\text {-Adding a social } \\
\text { worker to the } \\
\text { team did not } \\
\text { allow a larger } \\
\text { panel size } \\
\text {-working in } \\
\text { inter- } \\
\text { disciplinary } \\
\text { teams increases } \\
\text { patient panel } \\
\text { size }\end{array}$ & $\begin{array}{l}\text { Focused only } \\
\text { on } \mathrm{CHCs}\end{array}$ \\
\hline $\begin{array}{l}\text { Oritz et al. } \\
(2010)\end{array}$ & $\begin{array}{l}\text { Examine the } \\
\text { relative } \\
\text { contribution of } \\
\text { NPs to rural } \\
\text { health clinics } \\
\text { (RHC) }\end{array}$ & $\begin{array}{l}\text { Secondary data } \\
\text { analysis }\end{array}$ & $\begin{array}{l}\text { 3,565 RHCs } \\
\text { United states } \\
\text { study }\end{array}$ & $\begin{array}{l}\text { Practice type } \\
\text { and size }\end{array}$ & $\begin{array}{l}\text { There were two } \\
\text { principal sources } \\
\text { of study data: the } \\
\text { Medicare Cost } \\
\text { Report and the } \\
\text { Area Resource File }\end{array}$ & $\begin{array}{l}\text { FHTs see more } \\
\text { patients (14) per } \\
\text { day than CHCs } \\
\text { (11) } \\
\text { Larger practices }\end{array}$ & $\begin{array}{l}\text { Focused on } \\
\text { RHC } \\
\text { Survey done in } \\
\text { the US, may } \\
\text { not be }\end{array}$ \\
\hline
\end{tabular}




\begin{tabular}{|c|c|c|c|c|c|c|c|}
\hline Source & Purpose & Design & Sample & Concepts & Instruments & Results & Comments \\
\hline & $\begin{array}{l}\text { productivity, } \\
\text { determine the } \\
\text { interrelationship } \\
\text { of efficiency } \\
\text { indicators of } \\
\text { RHCs, and } \\
\text { identify } \\
\text { contextual and } \\
\text { structural } \\
\text { factors that } \\
\text { influence the } \\
\text { variation in } \\
\text { efficiency }\end{array}$ & & & & $\begin{array}{l}\text { or ARF System } \\
\text { Additional sources } \\
\text { included the CMS } \\
\text { Online Survey } \\
\text { (2007) and } \\
\text { Certification } \\
\text { Reporting System } \\
\text { (OSCAR), the } \\
\text { Bureau of Labor } \\
\text { Statistics, the } \\
\text { Department of } \\
\text { Labor, and the } \\
\text { Bureau of Census } \\
\text { databases. }\end{array}$ & $\begin{array}{l}\text { are associated } \\
\text { with a larger } \\
\text { number of NPs }\end{array}$ & $\begin{array}{l}\text { representative } \\
\text { of Ontario NPs }\end{array}$ \\
\hline $\begin{array}{l}\text { Phillips, } \\
\text { Bazemore, and } \\
\text { Peterson (2014) }\end{array}$ & $\begin{array}{l}\text { Discussion } \\
\text { paper how } \\
\text { effective } \\
\text { healthcare must } \\
\text { be balanced } \\
\text { with efficiency }\end{array}$ & & $\begin{array}{l}\text { United states } \\
\text { study }\end{array}$ & $\begin{array}{l}\text { Inter- } \\
\text { disciplinary } \\
\text { team }\end{array}$ & & $\begin{array}{l}\text { Inter- } \\
\text { professional } \\
\text { practice has } \\
\text { great potential to } \\
\text { improve } \\
\text { continuity of } \\
\text { care for patients }\end{array}$ & $\begin{array}{l}\text { Study done in } \\
\text { the US, may } \\
\text { not be } \\
\text { representative } \\
\text { of Ontario NPs }\end{array}$ \\
\hline $\begin{array}{l}\text { Poghosyan \& } \\
\text { Aiken (2015) }\end{array}$ & $\begin{array}{l}\text { Identify the } \\
\text { organizational } \\
\text { barriers that } \\
\text { hinder NPs } \\
\text { optimal use }\end{array}$ & $\begin{array}{l}\text { Cross-sectional } \\
\text { survey design }\end{array}$ & $\begin{array}{l}592 \text { NPs } \\
\text { United states } \\
\text { study }\end{array}$ & $\begin{array}{l}\text { Inter- } \\
\text { disciplinary } \\
\text { team and NP } \\
\text { physicians } \\
\text { collaboration }\end{array}$ & $\begin{array}{l}\text { Survey focused on: } \\
\text { organizational } \\
\text { support available } \\
\text { to them, } \\
\text { relationships } \\
\text { between NPs and } \\
\text { administration, } \\
\text { their job } \\
\text { satisfaction, and } \\
\text { intentions of } \\
\text { leaving their jobs }\end{array}$ & $\begin{array}{l}\text { NPs report lack } \\
\text { of org support } \\
\text { and resources } \\
\text { Problematic } \\
\text { relationships } \\
\text { often with } \\
\text { administrators } \\
\text { and/or } \\
\text { physicians }\end{array}$ & $\begin{array}{l}\text { Study done in } \\
\text { the US, may } \\
\text { not be } \\
\text { representative } \\
\text { of Ontario NPs }\end{array}$ \\
\hline $\begin{array}{l}\text { Poghosyan et al. } \\
(2015)\end{array}$ & $\begin{array}{l}\text { The aims of this } \\
\text { study were to } \\
\text { investigate NP }\end{array}$ & $\begin{array}{l}\text { Cross-sectional } \\
\text { survey design, } \\
\text { descriptive }\end{array}$ & $\begin{array}{l}\text { In MA } 291 \\
\text { NPs } \\
\text { In NY } 278\end{array}$ & $\begin{array}{l}\text { Personnel } \\
\text { support }\end{array}$ & $\begin{array}{l}\text { Practice } \\
\text { environments were } \\
\text { measured using the }\end{array}$ & $\begin{array}{l}\text { Nurse } \\
\text { practitioners } \\
\text { reported }\end{array}$ & $\begin{array}{l}\text { Study done in } \\
\text { the US, may } \\
\text { not be }\end{array}$ \\
\hline
\end{tabular}




\begin{tabular}{|c|c|c|c|c|c|c|c|}
\hline Source & Purpose & Design & Sample & Concepts & Instruments & Results & Comments \\
\hline & $\begin{array}{l}\text { practice } \\
\text { environments in } \\
\text { two states, } \\
\text { Massachusetts } \\
\text { (MA) and New } \\
\text { York State } \\
\text { (NY), and } \\
\text { determine the } \\
\text { impact of state } \\
\text { and } \\
\text { organization on } \\
\text { NP practice } \\
\text { environment }\end{array}$ & $\begin{array}{l}\text { stats and } \\
\text { multivariate } \\
\text { analysis }\end{array}$ & $\begin{array}{l}\text { NPs } \\
\text { United states } \\
\text { study }\end{array}$ & & $\begin{array}{l}\text { Nurse Practitioner } \\
\text { Primary Care } \\
\text { Organizational } \\
\text { Climate } \\
\text { Questionnaire in } \\
\text { terms of NP- } \\
\text { physician } \\
\text { relations, NP- } \\
\text { administration } \\
\text { relations, support, } \\
\text { NP role } \\
\text { comprehension, } \\
\text { and NP } \\
\text { independent } \\
\text { practice }\end{array}$ & $\begin{array}{l}\text { favorable } \\
\text { relationships } \\
\text { with physicians, } \\
\text { deficiencies in } \\
\text { their } \\
\text { relationships } \\
\text { with } \\
\text { administrators, } \\
\text { and lack of } \\
\text { clerical and } \\
\text { personnel } \\
\text { support }\end{array}$ & $\begin{array}{l}\text { representative } \\
\text { of Ontario NPs }\end{array}$ \\
\hline $\begin{array}{l}\text { Poghosyan, } \\
\text { Lucero, Rauch \& } \\
\text { Berkowitz } \\
(2012)\end{array}$ & $\begin{array}{l}\text { To describe } \\
\text { how the NP } \\
\text { workforce is } \\
\text { growing and } \\
\text { how NPs can be } \\
\text { utilized to } \\
\text { alleviate } \\
\text { workforce } \\
\text { shortages }\end{array}$ & $\begin{array}{l}\text { Literature } \\
\text { Review }\end{array}$ & $\begin{array}{l}\text { United states } \\
\text { study }\end{array}$ & $\begin{array}{l}\text { Inter- } \\
\text { disciplinary } \\
\text { team }\end{array}$ & & $\begin{array}{l}\text { NPs view the } \\
\text { partnership } \\
\text { between } \\
\text { physicians and } \\
\text { NPs as } \\
\text { supervisory } \\
\text { rather than } \\
\text { collaborative } \\
\text { and report } \\
\text { dissatisfaction } \\
\text { with intra- } \\
\text { practice } \\
\text { partnerships }\end{array}$ & $\begin{array}{l}\text { Study done in } \\
\text { the US, may } \\
\text { not be } \\
\text { representative } \\
\text { of Ontario NPs }\end{array}$ \\
\hline $\begin{array}{l}\text { Poghosyan, } \\
\text { Nannini, and } \\
\text { Clarke (2013) }\end{array}$ & $\begin{array}{l}\text { The purpose of } \\
\text { this review is to } \\
\text { investigate } \\
\text { literature } \\
\text { related to orga- } \\
\text { nizational } \\
\text { climate, define }\end{array}$ & $\begin{array}{l}\text { Literature } \\
\text { Review }\end{array}$ & $\begin{array}{l}52 \text { peer } \\
\text { reviewed } \\
\text { articles } \\
\text { United states } \\
\text { study }\end{array}$ & $\begin{array}{l}\mathrm{NP} \\
\text { autonomy }\end{array}$ & $\begin{array}{l}\text { A search was } \\
\text { conducted using } \\
\text { MEDLINE, } \\
\text { PubMed, } \\
\text { HealthSTAR/Ovid, } \\
\text { ISI Web of } \\
\text { Science, and }\end{array}$ & $\begin{array}{l}\text {-PHC } \\
\text { organizational } \\
\text { environments } \\
\text { that are } \\
\text { restrictive } \\
\text { affects NP } \\
\text { autonomy, NPs }\end{array}$ & $\begin{array}{l}\text { Study done in } \\
\text { the US, may } \\
\text { not be } \\
\text { representative } \\
\text { of Ontario NPs }\end{array}$ \\
\hline
\end{tabular}




\begin{tabular}{|c|c|c|c|c|c|c|c|}
\hline Source & Purpose & Design & Sample & Concepts & Instruments & Results & Comments \\
\hline & $\begin{array}{l}\text { organizational } \\
\text { climate, and } \\
\text { identify its } \\
\text { domains for } \\
\text { nurse } \\
\text { practitioner } \\
\text { (NP) practice in } \\
\text { primary care } \\
\text { settings. }\end{array}$ & & & & $\begin{array}{l}\text { several other } \\
\text { health policy and } \\
\text { nursingy databases }\end{array}$ & $\begin{array}{l}\text { ability to } \\
\text { exercise clinical } \\
\text { judgment, and } \\
\text { initiative in } \\
\text { patient care. }\end{array}$ & \\
\hline Rayner (2014) & $\begin{array}{l}\text { The Community } \\
\text { Health Centre } \\
\text { (CHC) Panel } \\
\text { Size Handbook } \\
\text { outlines } \\
\text { procedures that } \\
\text { relate to (1) the } \\
\text { calculation of } \\
\text { current panel } \\
\text { sizes and (2) } \\
\text { adjusted target } \\
\text { panel sizes for } \\
\text { CHCs in } \\
\text { Ontario. } \\
\text { Following these } \\
\text { procedures will } \\
\text { ensure that all } \\
\text { CHCs calculate } \\
\text { panel size using } \\
\text { a consistent } \\
\text { formula. This } \\
\text { allows for } \\
\text { meaningful } \\
\text { comparisons } \\
\text { and reliable } \\
\text { projections. }\end{array}$ & & $\begin{array}{l}\text { NP, physician, } \\
\text { and other } \\
\text { healthcare } \\
\text { providers in } \\
\text { primary care } \\
\text { All ages } \\
\text { patient } \\
\text { population } \\
\text { Ontario study }\end{array}$ & $\begin{array}{l}\begin{array}{l}\text { Size of } \\
\text { Practice }\end{array} \\
\text { Patient panel } \\
\text { size }\end{array}$ & $\begin{array}{l}\text { SAMI-- } \\
\text { Standardized } \\
\text { Adjusted Clinical } \\
\text { Group (ACG) } \\
\text { Morbidity Index }\end{array}$ & $\begin{array}{l}\text {-Levels of } \\
\text { support staff, } \\
\text { and the number } \\
\text { of exam/consult } \\
\text { rooms are } \\
\text { significant } \\
\text { factors that } \\
\text { influence the } \\
\text { number of } \\
\text { primary care } \\
\text { clients that can } \\
\text { be managed } \\
\text {-NPs who had } \\
\text { their own } \\
\text { patients as a } \\
\text { PCP had greater } \\
\text { clinical decision } \\
\text { making } \\
\text { authority and } \\
\text { increased } \\
\text { productivity } \\
\text {-\# of exam } \\
\text { rooms must be } \\
\text { taken into } \\
\text { consideration } \\
\text { when }\end{array}$ & $\begin{array}{l}\text { Focus on CHC } \\
\text { and FHTs }\end{array}$ \\
\hline
\end{tabular}




\begin{tabular}{|c|c|c|c|c|c|c|c|}
\hline Source & Purpose & Design & Sample & Concepts & Instruments & Results & Comments \\
\hline & & & & & & $\begin{array}{l}\text { determining } \\
\text { provider } \\
\text { workload }\end{array}$ & \\
\hline $\begin{array}{l}\text { Reay, Patterson, } \\
\text { Halma, \& Steed } \\
(2006)\end{array}$ & $\begin{array}{l}\text { To report on the } \\
\text { experiences of } \\
\text { introducing a } \\
\text { nurse } \\
\text { practitioner } \\
\text { (NP) into a } \\
\text { rural physicians' } \\
\text { clinic in Taber, } \\
\text { Alberta }\end{array}$ & $\begin{array}{l}\text { Case study, } \\
\text { grounded } \\
\text { theory } \\
\text { qualitative } \\
\text { approach }\end{array}$ & $\begin{array}{l}\text { A rural } \\
\text { community- } \\
\text { based family } \\
\text { practice in } \\
\text { Taber, Alberta } \\
20 \text { relevant } \\
\text { stakeholders }\end{array}$ & $\begin{array}{l}\text { Indirect } \\
\text { patient care } \\
\text { activities }\end{array}$ & $\begin{array}{l}\text { Open-ended } \\
\text { interviews } \\
\text { Patient survey }\end{array}$ & $\begin{array}{l}\text { Part of the NP } \\
\text { role was to work } \\
\text { closely with } \\
\text { other clinic staff } \\
\text { to develop } \\
\text { programs for } \\
\text { particular } \\
\text { chronic diseases } \\
\text { to improve } \\
\text { patient } \\
\text { outcomes }\end{array}$ & $\begin{array}{l}\text { Results from } \\
\text { rural PHC } \\
\text { clinic in } \\
\text { Alberta }\end{array}$ \\
\hline Roots (2014) & $\begin{array}{l}\text { Identify the } \\
\text { changes } \\
\text { associated with } \\
\text { the introduction } \\
\text { of the NP role } \\
\text { into fee-for- } \\
\text { service } \\
\text { community } \\
\text { based primary } \\
\text { care practices }\end{array}$ & $\begin{array}{l}\text { Multiple case } \\
\text { study using } \\
\text { mixed methods }\end{array}$ & $\begin{array}{l}3 \text { sites- two } \\
\text { rural, one } \\
\text { urban in } \\
\text { British } \\
\text { Columbia } \\
\text { GPs, NPs, } \\
\text { other practice } \\
\text { staff, } \\
\text { community } \\
\text { based health } \\
\text { providers, } \\
\text { health } \\
\text { authority } \\
\text { representative } \\
\text { from each site }\end{array}$ & $\begin{array}{l}\text { Direct patient } \\
\text { care activities } \\
\mathrm{NP} \\
\text { autonomy } \\
\text { Inter- } \\
\text { disciplinary } \\
\text { team }\end{array}$ & $\begin{array}{l}\text { Interviews, } \\
\text { observational data, } \\
\text { archival records, } \\
\text { chart reviews, field } \\
\text { notes }\end{array}$ & $\begin{array}{l}-88 \% \text { of NP } \\
\text { time in direct } \\
\text { clinical care } \\
\text {-Optimizing NP } \\
\text { scope of practice } \\
\text { results in } \\
\text { improved } \\
\text { patient safety, } \\
\text { inter- } \\
\text { professional } \\
\text { relationships } \\
\text { and better } \\
\text { patient health } \\
\text { outcomes } \\
\text {-NPs broke } \\
\text { down "siloed" } \\
\text { practice }\end{array}$ & $\begin{array}{l}\text { BC based } \\
\text { study }\end{array}$ \\
\hline $\begin{array}{l}\text { Sangster- } \\
\text { Gormley et al. } \\
(2012)\end{array}$ & $\begin{array}{l}\text { To better } \\
\text { understand how } \\
\text { NPs in British } \\
\text { Columbia (BC) }\end{array}$ & $\begin{array}{l}\text { Cross-sectional } \\
\text { survey design }\end{array}$ & $\begin{array}{l}37 \text { NPs } \\
\text { returned the } \\
\text { survey }\end{array}$ & $\begin{array}{l}\text { Indirect } \\
\text { patient care } \\
\text { activities }\end{array}$ & Survey & $\begin{array}{l}\text { NPs spend } \\
\text { approximately } \\
10 \text { hours per } \\
\text { week in non- }\end{array}$ & $\begin{array}{l}\text { BC based } \\
\text { study }\end{array}$ \\
\hline
\end{tabular}




\begin{tabular}{|c|c|c|c|c|c|c|c|}
\hline Source & Purpose & Design & Sample & Concepts & Instruments & Results & Comments \\
\hline & $\begin{array}{l}\text { are practicing } \\
\text { from Sept } \\
2011 \text { - January } \\
2012\end{array}$ & & $\begin{array}{l}\text { British } \\
\text { Columbia } \\
\text { study }\end{array}$ & $\begin{array}{l}\text { Inter- } \\
\text { disciplinary } \\
\text { team }\end{array}$ & & $\begin{array}{l}\text { clinical } \\
\text { activities } \\
\text { including } \\
\text { management, } \\
\text { leadership, team } \\
\text { meetings, } \\
\text { community } \\
\text { development, } \\
\text { and education } \\
\text { and training of } \\
\text { other staff } \\
-74 \% \text { of NPs } \\
\text { work in direct } \\
\text { relationship with } \\
\text { a physician, } \\
68 \% \text { satisfied } \\
\text { with this } \\
\text { relationship } \\
\text {-Specialist } \\
\text { physicians will } \\
\text { deny referrals }\end{array}$ & \\
\hline $\begin{array}{l}\text { Sangster- } \\
\text { Gormley et al. } \\
\text { (2015) }\end{array}$ & $\begin{array}{l}\text { To evaluate the } \\
\text { integration of } \\
\text { NPs into the BC } \\
\text { healthcare } \\
\text { system and } \\
\text { determine } \\
\text { changes that } \\
\text { occurred when } \\
\text { NPs became } \\
\text { members of the } \\
\text { health team }\end{array}$ & $\begin{array}{l}\text { Multi-phase } \\
\text { mixed } \\
\text { methods- } \\
\text { survey and } \\
\text { interviews }\end{array}$ & $\begin{array}{l}38 \text { surveys and } \\
30 \text { interviews } \\
\text { completed } \\
\text { with co- } \\
\text { workers } \\
\text { British } \\
\text { Columbia } \\
\text { study }\end{array}$ & $\begin{array}{l}\text { Inter- } \\
\text { disciplinary } \\
\text { team and NP- } \\
\text { physician } \\
\text { collaboration }\end{array}$ & $\begin{array}{l}\text { NPs in BC } \\
\text { completed a } \\
\text { practice patterns } \\
\text { survey in year one } \\
\text { of this study and } \\
\text { then NPs } \\
\text { distributed the } \\
\text { same surveys to } \\
\text { co-workers }\end{array}$ & $\begin{array}{l}\text { NPs contribute } \\
\text { to team } \\
\text { functioning and } \\
\text { allow more } \\
\text { patients to be } \\
\text { accepted to the } \\
\text { practice }\end{array}$ & $\begin{array}{l}\text { BC study, may } \\
\text { not be } \\
\text { representative } \\
\text { of Ontario } \\
\text { PHC } \\
\text { Only } 38 \\
\text { survey } \\
\text { respondents }\end{array}$ \\
\hline $\begin{array}{l}\text { Sloan et al. } \\
\text { (2006) }\end{array}$ & $\begin{array}{l}\text { To conduct a } \\
\text { survey of all } \\
\text { PHC NPs and }\end{array}$ & $\begin{array}{l}\text { Cross-sectional } \\
\text { survey }\end{array}$ & $\begin{array}{l}\text { All NPs } \\
\text { practicing in } \\
\text { Ontario in }\end{array}$ & $\begin{array}{l}\text { Direct patient } \\
\text { care activities }\end{array}$ & $\begin{array}{l}\text { Questionnaire for } \\
\text { both PHC NPs and } \\
\text { ACNPs was }\end{array}$ & $\begin{array}{l}\text {-Response rate } \\
60 \% \\
\text {-NPs reported }\end{array}$ & $\begin{array}{l}\text { Focused on } \\
\text { acute care and } \\
\text { PHC NPs }\end{array}$ \\
\hline
\end{tabular}




\begin{tabular}{|c|c|c|c|c|c|c|c|}
\hline Source & Purpose & Design & Sample & Concepts & Instruments & Results & Comments \\
\hline & $\begin{array}{l}\text { ACNPs, in } \\
\text { order to } \\
\text { describe NPs in } \\
\text { Ontario with } \\
\text { respect to their } \\
\text { demographic } \\
\text { characteristics, } \\
\text { geographic } \\
\text { distribution, } \\
\text { employment } \\
\text { trends and } \\
\text { practice profiles }\end{array}$ & & $\begin{array}{l}2004 \\
\text { Survey mailed } \\
\text { to } 621 \mathrm{NPs}^{2}\end{array}$ & $\begin{array}{l}\text { Indirect } \\
\text { patient care } \\
\text { activities } \\
\text { Personnel } \\
\text { support }\end{array}$ & $\begin{array}{l}\text { developed in } \\
\text { consultation with } \\
\text { the Advisory } \\
\text { Committee for the } \\
\text { NPAO Electronic } \\
\text { Registry Project } \\
\text { and with the } \\
\text { Project Manager } \\
\text { Pilot tested for } \\
\text { content validity }\end{array}$ & $\begin{array}{l}75 \% \text { of their } \\
\text { time was spent } \\
\text { in direct patient } \\
\text { care } \\
\text {-NPs reported } \\
\text { spending } 12 \% \text { of } \\
\text { their time in } \\
\text { administrative } \\
\text { duties, about } 7 \% \\
\text { teaching, and } \\
4 \% \text { doing } \\
\text { research or other } \\
\text { scholarly work } \\
\text {-18\% of PHC } \\
\text { NPs had on-call } \\
\text { responsibilities } \\
\text {-Increased staff } \\
\text { support, } \\
\text { secretarial, } \\
\text { admin, and } \\
\text { housekeeping } \\
\text { increases clinic } \\
\text { productivity and } \\
\text { patient panel } \\
\text { size }\end{array}$ & \\
\hline Thibeault (2011) & $\begin{array}{l}\text { The purpose of } \\
\text { this project is to } \\
\text { design, develop, } \\
\text { implement, and } \\
\text { evaluate a } \\
\text { Nurse } \\
\text { Practitioner } \\
\text { (NP)-led } \\
\text { primary }\end{array}$ & Case study & $\begin{array}{l}6 \text { full-time } \\
\text { NPs can each } \\
\text { serve } 800 \\
\text { patients } \\
\text { Ontario study }\end{array}$ & $\begin{array}{l}\text { Indirect } \\
\text { patient care } \\
\text { activities }\end{array}$ & $\begin{array}{l}\text { Patient encounters } \\
\text { and NP data } \\
\text { collected }\end{array}$ & $\begin{array}{l}\text { NPs working in } \\
\text { NPLC spend } \\
\text { more time in } \\
\text { administrative } \\
\text { activities and } \\
\text { work in multiple } \\
\text { sites }\end{array}$ & $\begin{array}{l}\text { Focus on one } \\
\text { NPLC }\end{array}$ \\
\hline
\end{tabular}




\begin{tabular}{|c|c|c|c|c|c|c|c|}
\hline Source & Purpose & Design & Sample & Concepts & Instruments & Results & Comments \\
\hline & $\begin{array}{l}\text { healthcare } \\
\text { clinic in } \\
\text { northwestern } \\
\text { Ontario. }\end{array}$ & & & & & & \\
\hline $\begin{array}{l}\text { Tomblin Murphy } \\
\text { (2004) }\end{array}$ & $\begin{array}{l}\text { The purpose of } \\
\text { this work was } \\
\text { to review and } \\
\text { synthesize the } \\
\text { current national } \\
\text { and } \\
\text { international } \\
\text { literature on } \\
\text { recruitment and } \\
\text { retention } \\
\text { activities } \\
\text { related } \\
\text { specifically to } \\
\text { PHCNPs }\end{array}$ & $\begin{array}{l}\text { Literature } \\
\text { Review }\end{array}$ & Ontario study & $\begin{array}{l}\text { NP } \\
\text { autonomy }\end{array}$ & $\begin{array}{l}\text { This literature was } \\
\text { accessed through } \\
\text { major health } \\
\text { databases } \\
\text { including } \\
\text { CINAHL, Pub } \\
\text { Med and the } \\
\text { Cochrane Library. } \\
\text { In addition, the } \\
\text { electronic grey } \\
\text { literature } \\
\text { pertaining to } \\
\text { PHCNPs was } \\
\text { reviewed }\end{array}$ & $\begin{array}{l}62 \% \text { of NPs } \\
\text { indicated that } \\
\text { autonomy was } \\
\text { one of the most } \\
\text { positive aspects } \\
\text { of their job }\end{array}$ & $\begin{array}{l}\text { No focus on } \\
\text { NP patient } \\
\text { panel size }\end{array}$ \\
\hline $\begin{array}{l}\text { van Soeren et al. } \\
(2009)\end{array}$ & $\begin{array}{l}\text { To examine } \\
\text { NP-PHC } \\
\text { demographics, } \\
\text { geographic } \\
\text { distribution, } \\
\text { employment } \\
\text { trends, and } \\
\text { practice profiles }\end{array}$ & $\begin{array}{l}\text { Cross-sectional } \\
\text { survey }\end{array}$ & $\begin{array}{l}\text { Surveys sent } \\
\text { to } 589 \text { NPs in } \\
\text { Ontario }\end{array}$ & $\begin{array}{l}\text { Direct patient } \\
\text { care activities } \\
\text { Personnel } \\
\text { support } \\
\text { NP } \\
\text { autonomy }\end{array}$ & $\begin{array}{l}\text { Survey designed } \\
\text { by NPAO } \\
\text { Electronic Registry } \\
\text { Advisory } \\
\text { Committee and the } \\
\text { CRaNHR team } \\
\text { Survey pilot tested } \\
\text { with } 13 \text { NPs for } \\
\text { content validity }\end{array}$ & $\begin{array}{l}\text {-Response rate } \\
\text { was } 60 \% \\
-74 \% \text { in direct } \\
\text { clinical care } \\
\text {-How NPs were } \\
\text { frustrated wit } \\
\text { the lack of } \\
\text { funding of } \\
\text { clerical support } \\
\text {-NPs viewed not } \\
\text { practicing to } \\
\text { their full scope } \\
\text { as a barrier to } \\
\text { care that was } \\
\text { frustrating }\end{array}$ & $\begin{array}{l}\text { Results } \\
\text { represent acute } \\
\text { care and PHC } \\
\text { NPs }\end{array}$ \\
\hline $\begin{array}{l}\text { Venning et al. } \\
(2000)\end{array}$ & $\begin{array}{l}\text { To compare the } \\
\text { cost }\end{array}$ & $\begin{array}{l}\text { Multi-centre } \\
\text { RCT }\end{array}$ & $\begin{array}{l}20 \text { general } \\
\text { practices in }\end{array}$ & $\begin{array}{l}\text { Indirect } \\
\text { patient care }\end{array}$ & $\begin{array}{l}\text { Consultation } \\
\text { process (length of }\end{array}$ & $\begin{array}{l}\text { NPs spent a } \\
\text { mean of } 1.33\end{array}$ & $\begin{array}{l}\text { United } \\
\text { Kingdom }\end{array}$ \\
\hline
\end{tabular}




\begin{tabular}{|c|c|c|c|c|c|c|c|}
\hline Source & Purpose & Design & Sample & Concepts & Instruments & Results & Comments \\
\hline & $\begin{array}{l}\text { effectiveness of } \\
\text { general } \\
\text { practitioners } \\
\text { and nurse } \\
\text { practitioners as } \\
\text { first point of } \\
\text { contact in } \\
\text { primary care. }\end{array}$ & & $\begin{array}{l}\text { England and } \\
\text { Wales } \\
1292 \text { patients } \\
\text { (651 general } \\
\text { practitioner } \\
\text { visits and } 641 \\
\text { NP visits) }\end{array}$ & activities & $\begin{array}{l}\text { consultation, } \\
\text { examinations, } \\
\text { prescriptions, } \\
\text { referrals), patient } \\
\text { satisfaction, health } \\
\text { status, return clinic } \\
\text { visits over two } \\
\text { weeks, and costs }\end{array}$ & $\begin{array}{l}\text { minutes per } \\
\text { patient waiting } \\
\text { for a } \\
\text { prescription } \\
\text { signature from } \\
\text { the family } \\
\text { physician }\end{array}$ & study \\
\hline VHA (2009) & $\begin{array}{l}\text { Establishes the } \\
\text { guidelines for } \\
\text { use of PCMM } \\
\text { at all VHA } \\
\text { Primary Care } \\
\text { sites of care. }\end{array}$ & & $\begin{array}{l}\text { United States } \\
\text { report }\end{array}$ & $\begin{array}{l}\text { Personnel } \\
\text { support } \\
\text { Practice size } \\
\text { Inter- } \\
\text { disciplinary } \\
\text { team }\end{array}$ & & $\begin{array}{l}\text {-Recommends } \\
2.17 \text { full-time } \\
\text { equivalent } \\
\text { (FTE) support } \\
\text { staff per FTE } \\
\text { primary care } \\
\text { provider (PCP) } \\
\text { and three exam } \\
\text { rooms in order } \\
\text { to support a full- } \\
\text { time patient } \\
\text { panel of } \\
\text { approximately } \\
1,200 \text { patients } \\
\text { receiving } \\
\text { comprehensive } \\
\text { care } \\
\text {-Multi- } \\
\text { disciplinary } \\
\text { teams increases } \\
\text { patient panel } \\
\text { size }\end{array}$ & $\begin{array}{l}\text { US report and } \\
\text { data, may not } \\
\text { be } \\
\text { representative } \\
\text { of Ontario NPs }\end{array}$ \\
\hline VHA (2014) & $\begin{array}{l}\text { This Veterans } \\
\text { Health } \\
\text { Administration } \\
\text { (VHA) } \\
\text { Handbook }\end{array}$ & & $\begin{array}{l}\text { United States } \\
\text { report }\end{array}$ & $\begin{array}{l}\text { Personnel } \\
\text { support } \\
\text { Practice size }\end{array}$ & & $\begin{array}{l}\text {-Recommends a } \\
\text { support staff } \\
\text { ratio of at least } \\
\text { three FTE } \\
\text { support staff per }\end{array}$ & $\begin{array}{l}\text { US report and } \\
\text { data, may not } \\
\text { be } \\
\text { representative } \\
\text { of Ontario NPs }\end{array}$ \\
\hline
\end{tabular}




\begin{tabular}{|c|c|c|c|c|c|c|c|}
\hline Source & Purpose & Design & Sample & Concepts & Instruments & Results & Comments \\
\hline & $\begin{array}{l}\text { establishes the } \\
\text { procedures for } \\
\text { Patient Aligned } \\
\text { Care Teams } \\
\text { (PACTs) to } \\
\text { provide } \\
\text { Veterans with } \\
\text { primary care } \\
\text { that is patient- } \\
\text { centered, data } \\
\text { driven, } \\
\text { continuously } \\
\text { improving, } \\
\text { team-based, } \\
\text { accessible, } \\
\text { timely, } \\
\text { comprehensive, } \\
\text { coordinated, } \\
\text { and provides } \\
\text { continuity of } \\
\text { care over time. }\end{array}$ & & & $\begin{array}{l}\text { Inter- } \\
\text { disciplinary } \\
\text { team }\end{array}$ & & $\begin{array}{l}\text { FTE PCP for } \\
\text { "teamlets" } \\
3 \text { exam rooms } \\
\text { per PCP } \\
\text {-Multi- } \\
\text { disciplinary } \\
\text { teams increases } \\
\text { patient panel } \\
\text { size }\end{array}$ & \\
\hline $\begin{array}{l}\text { Waszynski, } \\
\text { Murakami, \& } \\
\text { Lewis (2000) }\end{array}$ & $\begin{array}{l}\text { This article } \\
\text { discusses the } \\
\text { results of a } \\
\text { group of } \\
\text { advanced } \\
\text { practice nurses } \\
\text { who designed } \\
\text { and } \\
\text { implemented a } \\
\text { care } \\
\text { coordination } \\
\text { model for high } \\
\text { risk older adults }\end{array}$ & $\begin{array}{l}\text { Model } \\
\text { development } \\
\text { and } \\
\text { implementation }\end{array}$ & $\begin{array}{l}\text { United States } \\
\text { study }\end{array}$ & $\begin{array}{l}\mathrm{NP} \\
\text { autonomy }\end{array}$ & $\begin{array}{l}\text { Process outcomes } \\
\text { and challenges } \\
\text { assessed }\end{array}$ & $\begin{array}{l}\text { NPs are often } \\
\text { not utilized to } \\
\text { their full scope } \\
\text { due to lack of } \\
\text { understanding of } \\
\text { the NP } \\
\text { competencies }\end{array}$ & $\begin{array}{l}\text { Study done in } \\
\text { the US, may } \\
\text { not be } \\
\text { representative } \\
\text { of Ontario NPs }\end{array}$ \\
\hline Watts et al. & To describe the & Case studies of & United States & NP direct & Interviews with & Group medical & Study done in \\
\hline
\end{tabular}




\begin{tabular}{|c|c|c|c|c|c|c|c|}
\hline Source & Purpose & Design & Sample & Concepts & Instruments & Results & Comments \\
\hline (2009) & $\begin{array}{l}\text { roles of nurse } \\
\text { practitioners } \\
\text { (NPs) in a novel } \\
\text { model of } \\
\text { healthcare } \\
\text { delivery for } \\
\text { patients with } \\
\text { chronic disease: } \\
\text { shared medical } \\
\text { appointments } \\
\text { (SMAs)/group } \\
\text { visits based on } \\
\text { the chronic care } \\
\text { model (CCM). }\end{array}$ & $\begin{array}{l}\text { three disease- } \\
\text { specific shared } \\
\text { medical } \\
\text { appointments }\end{array}$ & study & $\begin{array}{l}\text { patient care } \\
\text { activities }\end{array}$ & $\begin{array}{l}\text { staff participants } \\
\text { and sample of } \\
\text { patients from each } \\
\text { medical visit }\end{array}$ & $\begin{array}{l}\text { visits can } \\
\text { decrease } \\
\text { provider } \\
\text { backlog, lower } \\
\text { costs, provide } \\
\text { timely } \\
\text { appointments, } \\
\text { improve patient } \\
\text { satisfaction, and } \\
\text { increase } \\
\text { effectiveness of } \\
\text { chronic illness } \\
\text { management }\end{array}$ & $\begin{array}{l}\text { the US, may } \\
\text { not be } \\
\text { representative } \\
\text { of Ontario NPs }\end{array}$ \\
\hline $\begin{array}{l}\text { Way, Jones, } \\
\text { Baskerville \& } \\
\text { Busing (2001) }\end{array}$ & $\begin{array}{l}\text { To determine } \\
\text { what services } \\
\text { are provided by } \\
\text { NPs and family } \\
\text { physicians (FP) } \\
\text { in a rural } \\
\text { practice settings }\end{array}$ & Case study & $\begin{array}{l}2 \text { NPs, } 4 \text { FPs } \\
400 \text { patient } \\
\text { encounters } \\
\text { Ontario study }\end{array}$ & $\begin{array}{l}\text { NP } \\
\text { autonomy }\end{array}$ & $\begin{array}{l}\text { Data analyzed } \\
\text { from } 122 \mathrm{NP} \\
\text { patient encounters } \\
\text { and } 278 \mathrm{FP} \text { patient } \\
\text { encounters to } \\
\text { determine frequent } \\
\text { activities and } \\
\text { practice patterns }\end{array}$ & $\begin{array}{l}\text { NPs are often } \\
\text { not utilized to } \\
\text { their full scope } \\
\text { due to lack of } \\
\text { understanding of } \\
\text { the NP } \\
\text { competencies }\end{array}$ & $\begin{array}{l}\text { Physician } \\
\text { focused } \\
\text { Focus on rural } \\
\text { NP/FP } \\
\text { activities that } \\
\text { may vary in } \\
\text { other settings }\end{array}$ \\
\hline $\begin{array}{l}\text { Yoshida, Fenick } \\
\text { and Rosenthal } \\
(2014)\end{array}$ & $\begin{array}{l}\text { To determine if } \\
\text { group well- } \\
\text { child visits } \\
\text { (WCV) can be } \\
\text { cost neutral } \\
\text { compared to } \\
\text { individual } \\
\text { WCV by } \\
\text { varying health } \\
\text { care providers, } \\
\text { group size, and } \\
\text { physician salary }\end{array}$ & $\begin{array}{l}\text { Created } 6 \\
\text { economic } \\
\text { models to } \\
\text { evaluate the } \\
\text { costs of WCV }\end{array}$ & $\begin{array}{l}3 \text { for } \\
\text { individual } \\
\text { WCV } \\
\text { delivered by } \\
\text { (1) advanced } \\
\text { practice } \\
\text { registered } \\
\text { nurse, (2) } \\
\text { resident, and } \\
\text { (3) attending } \\
\text { and } 3 \text { for } \\
\text { group WCV } \\
\text { delivered by }\end{array}$ & $\begin{array}{l}\text { Direct patient } \\
\text { care activities }\end{array}$ & $\begin{array}{l}\text { For group WCV, } \\
\text { sensitivity analyses } \\
\text { were performed on } \\
\text { group size and } \\
\text { duration of } \\
\text { provider } \\
\text { participation }\end{array}$ & $\begin{array}{l}\text { Group visits } \\
\text { decrease } \\
\text { provider } \\
\text { backlog, lower } \\
\text { costs, provide } \\
\text { timely } \\
\text { appointments, } \\
\text { improve patient } \\
\text { satisfaction, and } \\
\text { increase } \\
\text { effectiveness of } \\
\text { chronic illness } \\
\text { management }\end{array}$ & $\begin{array}{l}\text { Study done in } \\
\text { the US, may } \\
\text { not be } \\
\text { representative } \\
\text { of Ontario NPs }\end{array}$ \\
\hline
\end{tabular}




\begin{tabular}{|c|c|c|c|c|c|c|c|}
\hline Source & Purpose & Design & Sample & Concepts & Instruments & Results & Comments \\
\hline & & & $\begin{array}{l}\text { (4) APRN } \\
\text { with a nurse } \\
\text { and social } \\
\text { worker; (5) } \\
\text { resident with } \\
\text { an attending, } \\
\text { nurse, and } \\
\text { child life } \\
\text { specialist; and } \\
\text { (6)attending } \\
\text { with a nurse } \\
\text { United states } \\
\text { study }\end{array}$ & & & & \\
\hline
\end{tabular}


Appendix E

Recruitment Flyer for Primary Care Today Conference
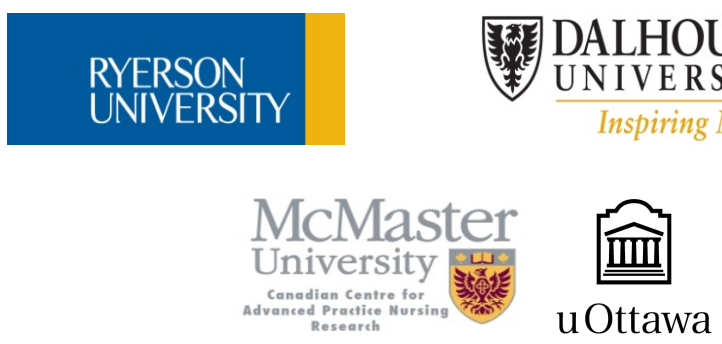

POntario

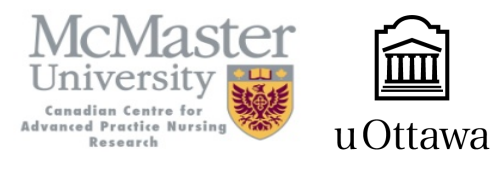

Centre de recherche
Centre afflliéa lUniversité de Montréal

\section{NP Patient Panel Size Study}

(Panel size is loosely described as patients registered or rostered to NPs)

\section{NPs, this is an Opportunity to tell the MOHLTC and Others about Patient, NP, \& Organizational Factors that Influence NP Patient Panel Size}

If you want to learn more about this study and/or how to participate, we need your name and email address to send you information about this important study

Please sign up or drop off your business
card

Thank you! 


\section{Appendix F}

\section{Email Recruitment Script to Send to Interested NPs From Primary Care Today Conference and NPs unable to Participate in Larger Research Study}

Email Subject Line: Research to Identify Patient, NP, and Organization Factors that Influence NP Patient Panel Size

Good Morning/Afternoon

My name is Nicole Bennewies and I am a Master of Nursing student at Ryerson University. You are receiving this email because you provided your email address at the conference "Primary Care Today" or expressed interest in participating in the study Measuring Factors that Influence Nurse Practitioner (NP) Activities and the Implications for Optimizing NP Patient Panel Size in Primary Healthcare (PHC) Settings. Panel size is loosely defined as the number of patients that are 'registered' or 'rostered' to a NP.

Under the supervision of Dr. Faith Donald, I am conducting a study for my Master's thesis to identify factors that influence NP patient panel size. This study has been approved by Ryerson University's Research Ethics Board. The information gained may improve inter-professional team functioning, as well as potentially contribute to efficient human resource planning and timely access to high quality patient care.

Attached is an overview of the study, the objectives, and the data collection procedures. Please feel free to email me with any questions.

If you wish to receive the questionnaire to participate in this study, please respond with your preferred Canada post mailing address. I will send up to two reminders about this email. If you no longer work in a primary health care setting, or you do not wish to receive the questionnaire or the reminders, please email me and I will remove your name from the list.

Thank you for your interest in this study!

Best Regards,

Nicole Bennewies

Nicole Bennewies RN, MN (student)

Daphne Cockwell School of Nursing, Ryerson University, Toronto, Ontario

Email: nbennewi@ryerson.ca

Faith Donald, NP-PHC, PhD (Thesis Supervisor)

Principle Investigator and Project Lead

Associate Professor, Daphne Cockwell School of Nursing, Ryerson University fdonald@,ryerson.ca

Tel: 416-979-5000, 1-6309\# 


\section{Appendix G}

\section{Ryerson Ethics Review Board Approval Letter}

\section{RYERSONUNIVERSITY}

\section{RESEARCH ETHICS BOARD}

To: Nicole Bennewies

Faculty of Nursing- Master of Nursing

Re: REB 2015-237: Identifying Factors that Influence Ontario Nurse Practitioners' (NP) Patient Panel Size in Primary Healthcare (PHC) Settings.

Date: July 23, 2015

\section{Dear Nicole Bennewies,}

The review of your protocol REB File REB 2015-237 is now complete. The project has been approved for a one year period. Please note that before proceeding with your project, compliance with other required University approvals/certifications, institutional requirements, or governmental authorizations may be required.

This approval may be extended after one year upon request. Please be advised that if the project is not renewed, approval will expire and no more research involving humans may take place. If this is a funded project, access to research funds may also be affected.

Please note that REB approval policies require that you adhere strictly to the protocol as last reviewed by the REB and that any modifications must be approved by the Board before they can be implemented. Adverse or unexpected events must be reported to the REB as soon as possible with an indication from the Principal Investigator as to how, in the view of the Principal Investigator, these events affect the continuation of the protocol.

Finally, if research subjects are in the care of a health facility, at a school, or other institution or community organization, it is the responsibility of the Principal Investigator to ensure that the ethical guidelines and approvals of those facilities or institutions are obtained and filed with the REB prior to the initiation of any research.

Please quote your REB file number (REB 2015-237) on future correspondence.

Congratulations and best of luck in conducting your research.

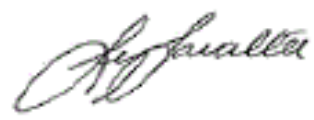

Lynn Lavallée, $\mathrm{Ph} . \mathrm{D}$.

Chair, Research Ethics Board 


\section{Appendix $\mathbf{H}$}

\section{Cover Letter for Province-wide Questionnaire}

October 29, 2015

Dear Nurse Practitioner,

Research Study Title: Identifying Factors that Influence Ontario Nurse Practitioners' (NP) Patient Panel Size in Primary Healthcare (PHC) Settings

You are invited to complete a questionnaire about factors that influence NP patient panel size. The reason you are receiving this questionnaire is because you consented through the College of Nurses of Ontario to release your address for research purposes or provided your address during the Primary Care Today or NP-Led Clinic Leadership conference.

Under the supervision of Dr. Faith Donald, I am conducting a study for my Master's thesis to identify factors that influence NP patient panel size. Panel size is loosely defined as the number of patients that are 'registered' or 'rostered' to a NP. This study has been approved by Ryerson University's Research Ethics Board. The information gained may improve inter-professional team functioning, as well as potentially contribute to efficient human resource planning and timely access to high quality patient care.

Attached to this letter is further information about the study and the questionnaire. A \$5.00 Tim Horton's gift card is enclosed as a token of appreciation for your time and effort to complete the questionnaire. If you have questions, please email either Faith or me.

If you wish to participate, please complete the attached questionnaire and return it in the enclosed, self-addressed, stamped envelope. I will send up to two reminder mailings about completing the questionnaire. If you no longer work in a primary health care setting, or you do not wish to receive the reminders, please email me and I will remove your name from the list. Thank you for considering the invitation to participate in this important research study.

Best Regards,

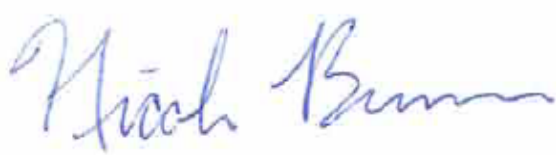

Nicole Bennewies

Nicole Bennewies RN, MN (student)

Daphne Cockwell School of Nursing, Ryerson University, Toronto, Ontario

Email: nbennewi@,ryerson.ca

Faith Donald, NP-PHC, PhD (Thesis Supervisor)

Associate Professor, Daphne Cockwell School of Nursing, Ryerson University

fdonald@ryerson.ca, Tel: 416-979-5000, 1-6309\# 


\section{Appendix I}

\section{Description of Variables by Question}

\begin{tabular}{|c|c|c|c|c|}
\hline \multicolumn{5}{|c|}{ Independent Variables (IV) } \\
\hline NP Factors & Conceptual Model & $\begin{array}{l}\text { Question } \\
\text { Number }\end{array}$ & $\begin{array}{c}\text { Level of } \\
\text { Measurement }\end{array}$ & Coding in SPSS (v23) \\
\hline $\begin{array}{cl}\text { Years of experience } \\
\text { - } & \text { As a NP in } \\
& \text { total } \\
\text { - } & \text { At current } \\
& \text { PHC practice } \\
\text { setting }\end{array}$ & $\begin{array}{l}\text { Provider Influencing } \\
\text { Factor } \leftarrow \rightarrow \text { NP roles } \\
\& \\
\text { activities } \leftarrow \rightarrow \text { patient } \\
\text { panel size }\end{array}$ & $41,42,43$ & $\begin{array}{l}\text { 41, 42, \& 43: } \\
\text { Ratio }\end{array}$ & $\begin{array}{l}\text { 41: \# of years } \\
\text { 42: \# of years } \\
\text { 43: \# of years }\end{array}$ \\
\hline NP Education & & $34,35,36$ & $\begin{array}{l}34,35, \& 36: \\
\text { Nominal/ } \\
\text { Ordinal }\end{array}$ & $\begin{array}{l}\text { 34: } 1=\text { Diploma, } 2= \\
\text { Baccalaureate, } 3= \\
\text { Master's, } 4= \\
\text { Doctorate } \\
\text { 35: Check all that } \\
\text { apply question } \\
\text { therefore each item } \\
\text { treated individually, } \\
\text { e.g., did you complete } \\
\text { the NP-PHC } \\
\text { certification } 2=\text { Yes, } \\
\text { 1= No } \\
\text { 36: } 1=\text { Post-RN or } \\
\text { Post-Baccalaureate } \\
\text { NP, } 2=\text { Master's or } \\
\text { Post-Master's NP, } 3= \\
\text { Doctorate in Nursing } \\
\text { Practice NP, } 4=\text { Other } \\
\text { Programs }\end{array}$ \\
\hline $\begin{array}{l}\text { Prior Nursing } \\
\text { Experience }\end{array}$ & & 39,40 & 39: Nominal & $\begin{array}{l}39: 1= \\
\text { Administration, } 2= \\
\text { Critical Care, } 3= \\
\text { Education, } 4= \\
\text { Government/Policy, } 5 \\
=\text { Home Care, } 6= \\
\text { Long-Term Care, } 7= \\
\text { Maternal Newborn, } 8 \\
=\text { Medical/Surgical, } 9 \\
=\text { Mental Health, } 10= \\
\text { Outpost Nursing, 11= } \\
\text { Pediatrics, } 12= \\
\text { Primary Health Care } \\
\text { (PHC), } 13=\text { Public } \\
\text { Health, } 14= \\
\text { Emergency/trauma, } 15\end{array}$ \\
\hline
\end{tabular}




\begin{tabular}{|c|c|c|c|c|}
\hline & & & 40: Ratio & $\begin{array}{l}=\text { Telephone triage, } 16 \\
=\text { Occupational health, } \\
17=\text { Specialized acute } \\
\text { care inpatient units, } 18 \\
=\text { More than one } \\
\text { indicated area, } 19= \\
\text { Research } \\
40: \# \text { of years entered, } \\
0=\text { not applicable }\end{array}$ \\
\hline Employment status & & $\begin{array}{l}45,46,47 \\
48,49,50\end{array}$ & $\begin{array}{l}45,46, \& 49 \text { : } \\
\text { Nominal/ } \\
\text { Ordinal } \\
\\
47,48, \& 50 \text { : } \\
\text { Ratio }\end{array}$ & $\begin{array}{l}45: 1=\text { Full-time }(\geq 35 \\
\text { hours/wk), } 2=\text { Part- } \\
\text { time }(21-34 \text { hours per } \\
\text { week }), 3=\text { Casual } \\
(\leq 20 \text { hours per week }) \\
\text { 46: } 2=\text { Yes, } 1=\text { No } \\
\text { 49: } 1=12 \text {-hour shifts, } \\
2=10 \text {-hour shifts, } 3= \\
8 \text {-hour shifts, } 4=4- \\
\text { hour shifts, } 5=6 \text { hour, } \\
6=7 \text { hours, } 7=9 \\
\text { hours, } 8=\text { Varies } \\
\text { 47: \# of hours entered } \\
\text { 48: \# of days entered } \\
\text { 50: \# of patients } \\
\text { entered for each } \\
\text { category }\end{array}$ \\
\hline Role confusion & & 51 & 51: Ordinal & 51: Score of 1 to 5 \\
\hline \multicolumn{3}{|c|}{ Sample demographics- \#38, 39} & $\begin{array}{l}\text { 37: Ratio } \\
\text { 38: Nominal }\end{array}$ & $\begin{array}{l}37: \text { \# of years } \\
38: 1=\text { female, } 2= \\
\text { male, } 3=\text { transgender, } \\
4=\text { Other }\end{array}$ \\
\hline \multicolumn{3}{|c|}{$\# 53$ addresses all NP factors } & 53: Ordinal & $\begin{array}{l}\text { 53: enter \# for each } \\
\text { category }\end{array}$ \\
\hline Patient Factors & Conceptual Model & $\begin{array}{l}\text { Question } \\
\text { Number }\end{array}$ & $\begin{array}{c}\text { Level of } \\
\text { Measurement }\end{array}$ & $\begin{array}{c}\text { Scoring in SPSS } \\
\text { (v23) }\end{array}$ \\
\hline Age & $\begin{array}{l}\text { Patient Influencing } \\
\text { Factor } \leftarrow \rightarrow \text { NP roles } \\
\& \\
\text { activities } \leftarrow \rightarrow \text { patient } \\
\text { panel size }\end{array}$ & 26 & $\begin{array}{l}\text { 26: Nominal/ } \\
\text { Ordinal }\end{array}$ & $\begin{array}{l}1=\text { All ages } \\
2=\text { Mainly children or } \\
\text { youth (ages } \leq 17 \text { ) } \\
3=\text { Mainly adults } \\
\text { (ages } 18-64 \text { ) } \\
4=\text { Mainly seniors } \\
\text { (ages } 65+\text { ) }\end{array}$ \\
\hline Gender & & 27 & 27: Nominal \& & $1=$ Female, $2=$ male \\
\hline
\end{tabular}




\begin{tabular}{|c|c|c|c|}
\hline & & Ratio & $\begin{array}{l}3=\text { transgender, } 4= \\
\text { mixed genders, } 5= \\
\text { Other } \\
\# \text { of minutes entered } \\
\text { for each category }\end{array}$ \\
\hline $\begin{array}{l}\text { Health status } \\
\text { - Acute illness } \\
\text { - Chronic } \\
\text { illness } \\
\text { - Co- } \\
\text { morbidities }\end{array}$ & 28,13 & $\begin{array}{l}\text { 28a: Nominal/ } \\
\text { Ordinal } \\
13 \& 28 b, c: \\
\text { Interval/Ratio }\end{array}$ & $\begin{array}{l}\text { 28a: } 1=\text { Mainly acute } \\
\text { conditions, } 2=\text { Mainly } \\
\text { chronic conditions, } 3= \\
\text { Mainly multi- } \\
\text { morbidities, } 4=\text { Even } \\
\text { mixture of acute, } \\
\text { chronic, and co- } \\
\text { morbid conditions } \\
\text { 28b: \% entered } \\
\text { 28c: \# of minutes } \\
\text { entered for each } \\
\text { category, } 0=\mathrm{N} / \mathrm{A} \\
\text { 13: \# of minutes (for } \\
\text { other category too), } 0 \\
=\text { Not applicable } \\
\text { Overall mean of } \\
\text { appointment time for } \\
\text { chronic illness }\end{array}$ \\
\hline Socioeconomic status & 29,30 & $\begin{array}{l}\text { 29: Nominal/ } \\
\text { Ordinal } \\
\text { 30: Ratio }\end{array}$ & $\begin{array}{l}\text { 29: } 1=\text { Mainly high } \\
\text { income earners, } 2= \\
\text { Mainly middle income } \\
\text { earners, } 3=\text { Mainly } \\
\text { low income earners, } 4 \\
=\text { Mixture of incomes } \\
30: \% \text { entered }\end{array}$ \\
\hline $\begin{array}{ll}\text { Same-day visits } \\
\text { - New patient to } \\
\text { practice } \\
\text { - New patient to } \\
\text { provider }\end{array}$ & 31,32 & $\begin{array}{l}\text { 31a,b,c: Ratio } \\
\text { 32: Nominal }\end{array}$ & $\begin{array}{l}\text { 31a,b,c: } \% \text { entered } \\
32: 1=\text { Patients are } \\
\text { new to me as a } \\
\text { provider, but known to } \\
\text { the practice } \\
2=\text { Patients are new } \\
\text { me as a provider and } \\
\text { new to the practice } \\
3=\text { They are patients I } \\
\text { previously have } \\
\text { treated and/or know } \\
4=\text { None of my } \\
\text { patient visits are walk- } \\
\text { ins } \\
5=\text { Mixture of } 1,2, \&\end{array}$ \\
\hline
\end{tabular}




\begin{tabular}{|c|c|c|c|c|}
\hline & & & & 3 \\
\hline $\begin{array}{l}\# 52 \text { addresses all } \\
\text { patient factors }\end{array}$ & & 52 & 52: Ordinal & $\begin{array}{l}\text { 52: enter \# for each } \\
\text { factor }\end{array}$ \\
\hline $\begin{array}{c}\text { Organizational } \\
\text { Factors }\end{array}$ & Conceptual Model & $\begin{array}{l}\text { Question } \\
\text { Number }\end{array}$ & $\begin{array}{c}\text { Level of } \\
\text { Measurement }\end{array}$ & $\begin{array}{c}\text { Scoring in SPSS } \\
(\mathrm{v} 23)\end{array}$ \\
\hline \multirow[t]{7}{*}{$\begin{array}{cl}\text { Direct } & \text { patient care } \\
\text { - } & \text { Time spent in } \\
& \text { direct patient } \\
& \text { care } \\
\text { - } & \text { Types of } \\
& \text { activities } \\
\text { - } & \text { Innovative } \\
& \text { health visits } \rightarrow \\
\text { group visits, } \\
\text { email, } \\
\text { telephone }\end{array}$} & \multirow[t]{7}{*}{$\begin{array}{l}\text { Organizational } \\
\text { Influencing } \\
\text { Factors } \leftarrow \rightarrow \text { NP roles } \\
\& \\
\text { activities } \leftarrow \rightarrow \text { patient } \\
\text { panel size }\end{array}$} & \multirow[t]{7}{*}{$12,13,15$} & $\begin{array}{l}\text { 12a: Yes- } \\
\text { Interval/Ratio, } \\
\text { No- Nominal/ } \\
\text { Ordinal }\end{array}$ & $\begin{array}{l}\text { 12: If Yes }=2 \text { and \# of } \\
\text { hours per week } \\
\text { entered and \# of } \\
\text { patients entered } \\
\text { If No }=1 \text { and } 0=\text { not } \\
\text { applicable in \# of } \\
\text { patients and \# of hours } \\
\text { columns } \\
\text { Overall means taken } \\
\text { (avg hours per week, } \\
\text { avg \# of patients per } \\
\text { week) }\end{array}$ \\
\hline & & & 12b: Ratio & $\begin{array}{l}\text { 12b: \# of hours per } \\
\text { week entered }\end{array}$ \\
\hline & & & 12c: Nominal & $\begin{array}{l}12 \mathrm{c}: 2=\text { Yes, } 1=\text { No I } \\
\text { go to the site for a full } \\
\text { shift, } 4=\text { No the travel } \\
\text { time is in addition to } \\
\text { my work hours, } 3=\mathrm{I} \\
\text { don't know, } 0=\text { not } \\
\text { applicable }\end{array}$ \\
\hline & & & $\begin{array}{l}\text { 13: Interval/ } \\
\text { Ratio }\end{array}$ & $\begin{array}{l}\text { 13: \# of minutes (for } \\
\text { other category too), } 0 \\
=\text { Not applicable }\end{array}$ \\
\hline & & & $\begin{array}{l}\text { 15a,b: Nominal/ } \\
\text { Ordinal }\end{array}$ & 15a: $2=$ Yes, $1=\mathrm{No}$ \\
\hline & & & & $\begin{array}{l}\text { 15b: Check all that } \\
\text { apply question } \\
\text { therefore each item } \\
\text { treated individually, } \\
\text { e.g., do you complete } \\
\text { group visits for } \\
\text { prenatal care } 2=\text { Yes, } \\
1=\text { No, } 0=\text { not } \\
\text { applicable }\end{array}$ \\
\hline & & & $\begin{array}{l}15 \mathrm{c}: \text { Interval/ } \\
\text { ratio }\end{array}$ & $\begin{array}{l}\text { 15c: \# of minutes } \\
\text { entered (including for } \\
\text { other); } 0=\text { not } \\
\text { applicable }\end{array}$ \\
\hline Indirect patient care & & 14 & 14: Ordinal & $14: 1=$ not at all, $2=$ \\
\hline
\end{tabular}




\begin{tabular}{|c|c|c|c|}
\hline $\begin{array}{ll}\text { - } & \text { Time spent in } \\
\text { indirect } \\
\text { patient care } \\
\text { - Types of } \\
\text { activities }\end{array}$ & & & $\begin{array}{l}\text { once a week, } 3=\text { twice } \\
\text { a week, } 4=\text { three } \\
\text { times per week, } 5=\geq \\
\text { four times per week, \# } \\
\text { of weeks entered }\end{array}$ \\
\hline Personnel support & 7,8 & 7 \& 8: Nominal & $\begin{array}{l}\text { 7: Check all that apply } \\
\text { question therefore } \\
\text { each item treated } \\
\text { individually, e.g., is } \\
\text { there physician(s) } 2= \\
\text { Yes, } 1=\text { No } \\
8: 1=\text { Someone else, } 2 \\
=\text { Me, } 3=\text { Both } \\
\text { answers checked, } 0= \\
\text { not applicable }\end{array}$ \\
\hline $\begin{array}{ll}\text { Practice } \\
\text { - } & \text { Type } \\
\text { - } & \text { Size (\# of } \\
& \text { exam rooms) } \\
\text { - } & \text { Location }\end{array}$ & $\begin{array}{l}44,50,1,2, \\
3\end{array}$ & $\begin{array}{l}44 \& 2: \\
\text { Nominal }\end{array}$ & $\begin{array}{l}\text { 44: } 1=\text { Aboriginal } \\
\text { Health Access Center, } \\
2=\text { Community } \\
\text { Health Center, } 3= \\
\text { Family Health Team, } \\
4=\text { NP-Led Clinic, } 5 \\
=\text { Physician office, } 6= \\
\text { Walk-in clinic, } 7= \\
\text { Specialty PHC clinic } \\
\text { 2: } 1=\text { City, } 2=\text { Inner- } \\
\text { city, } 3=\text { Small town, } 4 \\
=\text { Rural, } 5=\text { Remote } \\
\text { 50: \# of patients } \\
\text { entered } \\
\text { 1a: } 1=\text { single site, } \\
\text { multi-sites }=\# \text { of sites } \\
\text { entered } \\
\text { 1b: } 2=\text { Yes, } 1=\text { No, } 0 \\
=\text { Not applicable } \\
\# \text { of sites entered for } \\
\text { yes } \\
1 \mathrm{c}: \# \text { of hours entered, } \\
0=\text { Not applicable } \\
3: \# \text { of rooms entered }\end{array}$ \\
\hline $\begin{array}{l}\text { Level of NP autonomy } \\
\text { - Scope of } \\
\text { Practice } \\
\text { - Independence }\end{array}$ & $9,25,33$ & $9 \& 25:$ Ordinal & $\begin{array}{l}9: 1=\mathrm{I} \text { use little, } 2=\mathrm{I} \\
\text { use most, } 3=\mathrm{I} \text { use } \\
\text { about half, } 4=\mathrm{I} \text { use all }\end{array}$ \\
\hline
\end{tabular}




\begin{tabular}{|c|c|c|c|}
\hline $\begin{array}{l}\text { in decision } \\
\text { making, etc. }\end{array}$ & & $\begin{array}{l}\text { 33: Interval/ } \\
\text { Ratio }\end{array}$ & $\begin{array}{l}25: 1=\text { Dissatisfied, } 2 \\
=\text { Not very satisfied, } 3 \\
=\text { Unsure, } 4= \\
\text { Somewhat satisfied, } 5 \\
=\text { Satisfied } \\
\text { 33: \# of patients } \\
\text { entered }\end{array}$ \\
\hline $\begin{array}{l}\text { Interdisciplinary team } \\
\text { members \& Physician } \\
\text { collaboration }\end{array}$ & $\begin{array}{l}7,16,17, \\
18,19,20, \\
21,22,23, \\
24\end{array}$ & $\begin{array}{l}7,16,17,18,19, \\
20,21,22,23, \\
\text { \& 24: Nominal/ } \\
\text { Ordinal }\end{array}$ & $\begin{array}{l}\text { 7: Check all that apply } \\
\text { question therefore } \\
\text { each item treated } \\
\text { individually, e.g., is } \\
\text { there physician(s) } 2= \\
\text { Yes, } 1=\text { No } \\
\text { 16:1 = Dissatisfied, } 2 \\
=\text { Somewhat } \\
\text { dissatisfied, } 3= \\
\text { Unsure, } 4=\text { Somewhat } \\
\text { satisfied, } 5=\text { Satisfied } \\
\text { 17: } 1=\text { Disagree, } 2= \\
\text { Somewhat disagree, } 3 \\
=\text { Unsure, } 4= \\
\text { Somewhat agree, } 5= \\
\text { Agree } \\
\text { 18: Score of } 1 \text { to } 5 \\
\text { 19: } 0=\text { not applicable, } \\
1=\text { Within } 15 \\
\text { minutes, } 2=\text { Within } 1 \\
\text { hour, } 3=\text { Within } 4 \\
\text { hours, } 4=\text { Within } 1 \\
\text { day, } 5=\text { Within } 1 \\
\text { week, } 6=\text { Within } 3 \\
\text { weeks, } 7=\text { varies } \\
\text { 20: } 0=\text { Not applicable, } \\
1=\text { Daily, } 2= \\
\text { Weekly, } 3=\text { Monthly, } \\
4=\text { Quaterly, } 5= \\
\text { Annually, } 6=\text { Less } \\
\text { than once per year, } 7= \\
\text { Never, } 8=\text { Unsure, } 9 \\
=\text { Occasionally } \\
21: 1=\text { Sufficiently } \\
\text { fast for optimal patient } \\
\text { care } \\
2=\text { Information is } \\
\text { delayed but does not }\end{array}$ \\
\hline
\end{tabular}




\begin{tabular}{|c|c|c|c|}
\hline & & & $\begin{array}{l}\text { hinder ability to care } \\
\text { for patient } \\
3=\text { Information is } \\
\text { delayed and hinders } \\
\text { ability to care for } \\
\text { patient efficiently } \\
4=\text { Information is } \\
\text { delayed and has } \\
\text { negative effects on } \\
\text { patient health or health } \\
\text { outcomes } \\
\text { 22: } 2=\text { Yes, } 1=\text { No } \\
\text { 23: Check all that } \\
\text { apply question } \\
\text { therefore each item } \\
\text { treated individually, } \\
\text { e.g., Do patients book } \\
\text { themselves through a } \\
\text { web-based } \\
\text { appointment system } 2 \\
\text { = Yes, } 1=\text { No } \\
\text { 24: } 1=\text { Telephone, } 2= \\
\text { Healthcare connect, } 3 \\
=\text { Web/paper } \\
\text { application, } 4= \\
\text { Referral from another } \\
\text { HCP, } 5=\text { Our clinic is } \\
\text { not accepting new } \\
\text { patients, } 6=\text { Walk-ins, } \\
7=\text { Waiting list, } 8= \\
\text { Word of mouth, } 9= \\
\text { unsure }\end{array}$ \\
\hline EMR & 10,11 & $\begin{array}{l}10 \& 11: \\
\text { Nominal/ } \\
\text { Ordinal }\end{array}$ & $\begin{array}{l}\text { 10: } 2=\text { Yes, } 3=\text { No } \\
\text { but planning to adopt, } \\
1=\text { No } \\
\text { 11: } 1=\text { not at all, } 2= \\
\text { once a week, } 3=\text { twice } \\
\text { a week, } 4=\text { three } \\
\text { times a week, } 5=\geq \\
\text { four times per week, } 0 \\
=\text { not applicable } \\
\text { (skipped from } \\
\text { previous question) }\end{array}$ \\
\hline \multicolumn{2}{|c|}{ \#54- Addresses all for organizational factors } & 54: Ordinal & $\begin{array}{l}\text { 54: \# entered for each } \\
\text { category }\end{array}$ \\
\hline
\end{tabular}




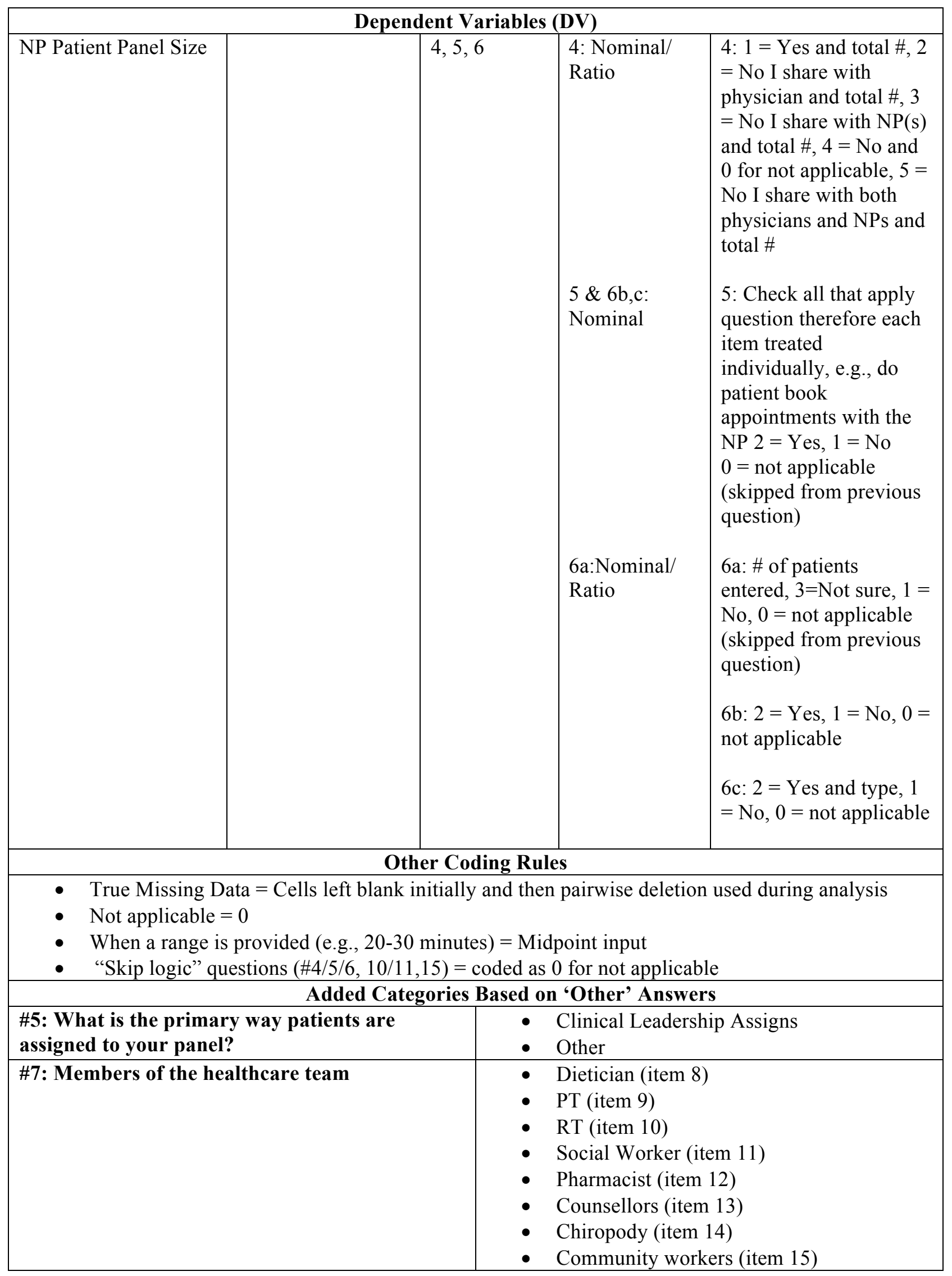




\begin{tabular}{|c|c|}
\hline & - Other (item 16) \\
\hline \#12: Direct Patient Care Activities & $\begin{array}{l}\text { - Other community visits } \\
\text { - Hospital visits }\end{array}$ \\
\hline \#15: Group Visits & $\begin{array}{ll}\text { - } & \text { New patient groups (item 9) } \\
\text { - } & \text { Mental health/social issues (item 10) } \\
\text { - } & \text { Palliative care (item 11) } \\
\end{array}$ \\
\hline $\begin{array}{l}\text { \#19: How soon are you able to urgently consult } \\
\text { with another HCP? }\end{array}$ & $\begin{array}{ll}\text { - } & \text { Varies } \\
\text { - } & \text { Not applicable } \\
\text { - } & \text { Within } 3 \text { weeks } \\
\end{array}$ \\
\hline $\begin{array}{l}\text { \#20: How often does a patient experience } \\
\text { problems due to uncoordinated care? }\end{array}$ & $\begin{array}{ll}\text { - } & \text { Not applicable } \\
\text { - } & \text { Unsure } \\
\text { - } & \text { Occasionally } \\
\end{array}$ \\
\hline \# 23: How are patient appointments made? & - $\quad$ Other (item 7) \\
\hline $\begin{array}{l}\text { \#24: How do patients first make contact with } \\
\text { your clinic? }\end{array}$ & $\begin{array}{ll}\text { - } & \text { Paper Application form (grouped under } \\
\text { code } 3 \text { ) } \\
\text { - Walk-ins } \\
\text { - Waiting list } \\
\text { - Word of mouth } \\
\text { - Unsure }\end{array}$ \\
\hline \#28: Common Health conditions & - Preventative/Health promotion \\
\hline \#32: Same day patient appointments & - Combination of more than one option \\
\hline \#36: NP Education & - Other programs \\
\hline \#39: Prior RN Experience & $\begin{array}{ll}\text { - } & \text { More than one indicated area } \\
\text { - } & \text { Other } \\
\end{array}$ \\
\hline \#44: Type of PHC setting & $\begin{array}{ll}\text { - } & \text { Physician office } \\
\text { - } & \text { Other } \\
\end{array}$ \\
\hline \#45: Employment Status & - Casual/locum \\
\hline \#49: Hours worked most often & $\begin{array}{ll} & 6 \text { hour } \\
- & 7 \text { hours } \\
\text { - } & 9 \text { hours } \\
\text { - } & \text { Varies } \\
\end{array}$ \\
\hline
\end{tabular}




\section{Appendix J}

\section{Questionnaire Cover Letter for Pilot Testing}

Research Study Title: Identifying Patient, NP, and Organization Factors that Influence NP Patient Panel Size

Hello

My name is Nicole Bennewies and I am a Master of Nursing student at Ryerson University. Under the supervision of Dr. Faith Donald, I am conducting a study for my Master's thesis to identify factors that influence NP patient panel size. Panel size is loosely defined as the number of patients that are 'registered' or 'rostered' to a NP. This study has been approved by Ryerson University's Research Ethics Board. The information gained may improve inter-professional team functioning, as well as potentially contribute to efficient human resource planning and timely access to high quality patient care.

Thank you for agreeing to pilot test this questionnaire, I appreciate any suggestions to strengthen the questionnaire. Changes will be made based on your feedback and the literature to ensure the questionnaire adequately identifies the important factors that influence NP patient panel size. The final questionnaire will be mailed later this Fall to all NPs working in primary health care in Ontario who consented through the CNO to be contacted for research or supplied their names to Faith. If there are no major changes to the questionnaire, I plan to include your responses in the database. Please read the consent to ensure that this is agreeable for you and let me know if you prefer to not have your data kept for the study.

Attached to this cover letter is the consent and questionnaire, an evaluation form regarding the questionnaire, and a 10-dollar Tim Horton's gift card as a token of appreciation for your time and effort. If you have any questions please feel free to email either Faith or myself.

Please complete the pilot test and return the questionnaire by mail by October 12, 2015 .

Best Regards,

Nicole Bennewies RN, MN (student)

Daphne Cockwell School of Nursing, Ryerson University

Toronto, Ontario

Email: nbennewi@ryerson.ca

Faith Donald, NP-PHC, PhD (Thesis Supervisor)

Principle Investigator and Project Lead

Associate Professor, Daphne Cockwell School of Nursing

Ryerson University

fdonald@,ryerson.ca

Tel: 416-979-5000, 1-6309\# 


\section{Appendix K}

\section{Pilot Testing Evaluation Form}

Study Title: Identifying Factors that Influence Ontario Nurse Practitioners' (NP) Patient Panel Size in Primary Healthcare (PHC) Settings

Please complete the questionnaire as you normally would if you were not part of the pilot test. However, as you work through please feel free to write comments directly on the questionnaire and/or this question form about the following items:

1) Are the instructions for completing the survey clearly written?

2) Are the questions easy to read and understand?

3) Is the content appropriate and/or are there any factors not covered?

4) Are response choices mutually exclusive and exhaustive?

5) Is the format of the survey easy to follow?

Thank you for your feedback! Please return the survey within two weeks (return by October 12, 2015) in the provided envelope. If you have misplaced the researcher-addressed stamped envelope please fax to 416-946-1792, attention Faith Donald. 


\section{References}

Abood, S. A. (2005). Analysis of the compensation arrangements experienced by primary care nurse practitioners in the managed care environment. (Unpublished doctoral dissertation) George Mason University, Fairfax, VA.

Altschuler, J., Margolius, D., Bodenheimer, T., \& Grumbach, K. (2012). Estimating a reasonable patient panel size for primary care physicians with team-based task delegation. Annals of Family Medicine, 10, 396-400.

American Association for Public Opinion Research (AAPOR). (2000). Standard definitions: Final dispositions of case codes and outcome rates for surveys. Ann Arbor, MI: Author.

Bertakis, K. D., Azari, R., Helms, L. J. Callahan, E. J., \& Robbins, J. A. (2000). Gender differences in the utilization of health care services. Journal of Family Practice, 49, $147-152$.

Bridges, D. R., Davidson, R. A., Odegard, P. S., Maki, I. V., \& Tomkowiak, J. (2011). Interprofessional collaboration: Three best practice models of interprofessional education. Medical Education Online, 16. doi: 10.3402/meo.v16i0.6035

Buerhaus, P.I., DesRoches, C.M., Dittus, R., \& Donelan, K. (2015). Practice characteristics of primary care nurse practitioners and physicians. Nursing Outlook, 63(2), 144-53. doi: 10.1016/j.outlook.2014.08.008.

Canadian Association of Schools of Nursing. (2012). Nurse practitioner education in Canada: National framework of guiding principles and essential components. Retrieved from http://casn.ca/wp-content/uploads/2014/12/FINALNPFrameworkEN20130131.pdf

Canadian Institute for Health Information. (2013). About the primary health care practice-based surveys. Retrieved from 
http://www.cihi.ca/CIHI-ext portal/pdf/internet/INFO_PHC_HANDOUT_EN

Canadian Nurses Association. (2004). Workforce management objective A: Workload

measurement tools. Retrieved from https://www.cna-aiic.ca/ /media/cna/page-

content/pdf-fr/workload_measurement_tools_e.pdf?la=en

Canadian Nurses Association. (2015). Primary health care. Retrieved from

https://www.cna-aiic.ca/on-the-issues/better-health/primary-health-care

Canadian Women's Health Network. (2005). Primary healthcare reform and women. Retrieved from http://www.nnewh.org/images/upload/attach/2753Primary\%20Health\%20Care \%20Reform\%20and\%20Women.pdf

Carryer, J., \& Yarwood, J. (2015). The nurse practitioner role: Solution or servant in improving primary health care service delivery. Collegian: Journal of the Royal College of Nursing, Australia, 22, 169-74.

Chumbler, N. R., Geller, J. M., \& Weier, A. W. (2000) The effects of clinical decision making on nurse practitioners' clinical productivity. Evaluation \& the Health Professions, 23, 284-305.

Cohen, J. (1988). Statistical power analysis for the behavioural sciences $\left(2^{\text {nd }}\right.$ ed.). Hillsdale, NJ: Lawrence Erlbaum.

College of Family Physicians Canada. (2012). Best advice: Panel size. Retrieved from http://www.cfpc.ca/uploadedFiles/Health_Policy/_PDFs/Final\%20June\%209\%2011\%20 Final\%20Panel\%20Size\%20Best\%20Advice.pdf

College of Nurses of Ontario. (2015). Membership statistics highlights 2015. Retrieved from http://www.cno.org/globalassets/docs/general/43069_stats/membership-statisticshighlights-2015.pdf 
College of Nurses of Ontario. (2014). Membership statistics highlights 2014. Retrieved from https://www.cno.org/globalassets/docs/general/43069_stats/43069_membershipstatisticshighlights.pdf

College of Nurses of Ontario. (2011). Practice standard: Nurse practitioner. Retrieved from http://www.cno.org/Global/docs/prac/41038_StrdRnec.pdf

Cook, J. V., Dickinson, H., \& Eccles, M. (2009). Response rates in postal surveys of healthcare professionals between 1996 and 2005: An observational study. BMC Health Services Research, 9, 160. doi: 10.1186/1472-6963-9-160

Dahrouge, S., Muldoon, L., Ward, N., Hogg, W., Russell, G., \& Taylor-Sussex, R. (2014). Roles of nurse practitioners and family physicians in community health centers. Canadian Family Physician, 60(11), 1020-1027.

Department of Veterans Affairs, Veteran Health Administration (2009). Primary care management module (PCMM): VHA handbook 1101.02 Veterans Health Administration transmittal sheet. Retrieved from http://www.va.gov/vhapublications/ViewPublication.asp?pub_ID=2017

Department of Veterans Affairs, Veteran Health Administration. (2014). Patient aligned care team (PACT) handbook. Retrieved from http://www.va.gov/vhapublications/ViewPublication.asp?pub_ID=2977

Deshefy-Longhi, T., Swartz, M. K., \& Grey, M. (2008). Characterizing nurse practitioner practice by sampling patient encounters: An APRNet study. Journal of the American Academy of Nurse Practitioners, 20, 281-287.

DiCenso, A., Bourgeault, I., Abelson, J., Martin-Misener, R., Kaasalainen, S., Carter, ... 
Kilpatrick, K. (2010). Utilization of nurse practitioners to increase patient access to primary healthcare in Canada - thinking outside the box. Nursing Leadership, 23(Special Issue), 239-259. Retrieved from http://www.longwoods.com/content/22281

DiCicco-Bloom, B., \& Cunningham, R. S. (2015). Complex patients and interprofessional relationships: Perceptions of primary care nurse practitioners and primary care physicians. Journal of the American Association of Nurse Practitioners, 27(11), 646-652.

Dierick-van Daele, A. T., Metsemakers, J. F., Derckx, E. W., Spreeuwenberg, C., \& Vrijhoef, H. J. (2009). Nurse practitioners substituting for general practitioners: Randomized controlled trial. Journal of Advanced Nursing, 65, 391-401.

Dierick-van Daele, A. T., Steuten, L. M., Metsemakers, J. F., Derckx, E. W., Spreeuwenberg, C., \& Vrijhoef, H. J. (2010). Economic evaluation of nurse practitioners versus GPs in treating common conditions. British Journal of General Practice, 60 (570), 28-35.

Dierick-van Daele, A. T., Steuten, L. M., Romeijin, A., Derckx, E. W., \& Vrijhoef, H. J. (2011). Is it economically viable to employ the nurse practitioner in general practice? Journal of Clinical Nursing, 20(3), 518-529.

Dillman, D. A. (2009). Internet, mail, and mixed-mode surveys: The tailored design method ( ${ }^{\mathrm{rd}}$ ed.). Hoboken, NJ: Wiley.

Donald, F., Bryant-Lukosius, D., Martin-Misener, R., Kaasalainen, S., Kilpatrick, K., Carter, N., ...DiCenso, A. (2010). Clinical nurse specialists and nurse practitioners: Title confusion and lack of role clarity. Nursing Leadership, 23(Special Issue), 189-210. Retrieved from http://www.longwoods.com/content/22276

Donald, F., Kilpatrick, K., Reid, K., Carter, N., Martin-Misener, R., Bryant-Lukosius, D., ... 
DiCenso, A. (2014). A systematic review of the cost-effectiveness of nurse practitioners and clinical nurse specialists: What is the quality of the evidence? Nursing Research and Practice, 2014, 1-28. . doi: 10.1155/2014/896587. Retrieved from http://www.hindawi.com/journals/nrp/2014/896587/

Donald, F., Martin-Misener, R., Bryant-Lukosius, D., Kilpatrick, K., Kaasalainen, S., Carter, N., ... DiCenso, A. (2010). The primary healthcare nurse practitioner role in Canada. Nursing Leadership, 23(Special Issue), 88-113. Retrieved from http://www.longwoods.com/content/22271

Donelan, K., DesRoches, C. M., Dittus, R. S., \& Buerhaus, P. (2013). Perspectives of physicians and nurse practitioners on primary care practice. New England Journal of Medicine, 368, 1898-906.

Draper, N. R., \& Smith, H. (2003). Applied regression analysis ( $3^{\text {rd }}$ ed.). New York, NY: Wiley. Duck, E., DeLia, D., \& Cantor, J. C. (2001). Primary care productivity and the health care safety net in New York City. Journal of Ambulatory Care Management, 24, 1-14.

Edwards, P., Roberts, I., Clarke, M., DiGuiseppi, C., Pratap, S., Wentz, R., \& Kwan, I. (2002). Increasing response rates to postal questionnaires: Systematic review. British Medical Journal, 324(7347), 1183.

Evans, R. E., Schneider, D., \& Barer, M. (2010). Health human resources productivity: What it is, how it's measured, why (how you measure) it matters, and who's thinking about it. Retrieved from www.cfhi fcass.ca/Migrated/PDF/ResearchReports/.../HHRP_en_FINAL.pdf

Fowler, F. J. (2009). Survey research methods (4th ed.). Thousand Oaks, CA: Sage.

Fox-Wasylyshyn, S., \& El-Masri, M. (2005). Handling missing data in self-report measures. 
Research in Nursing \& Health, 28, 488-495.

Glazier, R. H., Zagorski, B. M., \& Rayner, J. (2012). Comparison of primary care models in Ontario by demographics, case mix, and emergency department use, 2008/09 to 2009/10. ICES Investigative Report. Toronto: Institute for Clinical Evaluative Sciences. Retrieved from http://www.ices.on.ca/flip-publication/comparison-of-primary-care-models-inontario-by-demographics/index.html

Glenngård, A. H. (2013). Productivity and patient satisfaction in primary care- Conflicting or compatible goals? Health Policy, 111, 157-165. doi: 10.1016/j.healthpol.2013.04.012

Gorman, D. (2015). Developing health care workforces for uncertain futures. Academic Medicine, 90(4), 1-4.

Grove, S., Burns, N., \& Gray, J.R. (2013). The practice of nursing research: Appraisal, synthesis and generation of evidence (7th ed.). St. Louis, MO: Elsevier Saunders.

Grover, A., \& Niecko-Najjum, L. M. (2013). Primary care teams: Are we there yet? Implications for workforce planning. Academic Medicine, 88, 1827-1829.

Guey-Chi Chen, P., Mehrotra, A., \& Auerbach, D. I. (2014). Response: Effectiveness in primary care is paramount, but need not come at the expense of efficiency. Medical Care, 52, 99-100.

Haber, J., Strasser, S., Lloyd, M., Dorsen, C., Knapp, R., Auerhahn, C., ... Fulmer, T. (2009). The oral-systemic connection in primary care. The Nurse Practitioner, 34, 43-48.

Hayes, E. F. (2007). Embattled and embittered or empowered and evolving: Nurse practitioner attitudes toward managed care. Journal of the American Academy of Nurse Practitioner, $19,143-151$.

Health Canada. (2012). About primary health care. Retrieved from http://www.hc-sc.gc.ca/hcs- 
sss/prim/about-apropos-eng.php

Health Services Branch, Ministry of Health and Long-Term Care. (2015). Nurse practitioner referrals to physicians. Retrieved from http://www.health.gov.on.ca/english/providers/program/ohip/sob/sob_mn.html

Hing, E., Hooker, R. S., \& Ashman, J. J. (2011). Primary health care in community health centers and comparison with office-based practice. Journal of Community Health, 36, 406-413.

Hogg, W., Rowan, M., Russell, G., Geneau, R., \& Muldoon, L. (2008). Framework for primary care organizations: The structural domain. International Journal for Quality in Health Care, 20, 308-313.

Holcomb, L. O. (2000). A Delphi survey to identify activities of nurse practitioners in primary care. Clinical Excellence for Nurse Practitioners, 4, 163-172.

Horrocks, S., Anderson, E., \& Salisbury, C. (2002). Systematic review of whether nurse practitioners working in primary care can provide equivalent care to doctors. British Medical Journal, 324(7341), 819-823.

Huang, P. Y., Yano, E. M., Lee, M. L. Chang, B. L., \& Rubenstein, L. V. (2004). Variations in nurse practitioner use in Veterans Affairs primary care practices. Health Services Research, 39, 887-904.

Humbert, J., Legault, F., Dahrouge, S., Halabisky, B., Boyce, G., Hogg, W., \& Amos, S. (2007). Integration of nurse practitioners into a family health network. Canadian Nurse, 103, 3034.

IBM Business Consulting Services. (2003). Report on the integration of primary 
healthcare nurse practitioners into the province of Ontario. Retrieved from http://www.health.gov.on.ca/en/common/ministry/publications/reports/nurseprac03/nurse prac03_mn.aspx

Jennings, N., O’Reilly, G., Lee, G., Cameron, P., Free, B., \& Bailey, M. (2008). Evaluating outcomes of the nurse practitioner in Melbourne, Australia. Journal of Clinical Nursing, 17, 1044-1050. doi: $10.1111 / j .1365-2702.2007 .02038 . x$

Johnson, R. (2005). Shifting patterns of practice: Nurse practitioners in managed care environment. Research and Theory for Nursing Practice, 19, 323-340.

Kaasalainen, S., Martin-Misener, R., Kilpatrick, K., Harbman, P., Bryant-Lukosius, D., Donald, F., ...DiCenso, A. (2010). A historical overview of the development of advanced practice nursing roles in Canada. Nursing Leadership, 23(Special Issue), 35-60. http://www.longwoods.com/content/22268

Koren, I., Mian, O., \& Rukholm, E. (2010). Primary health care nurse practitioners in rural locations of Ontario: Demographic and practice profile. Centre for Rural and Northern Health Research, Laurentian University, Sudbury, Ontario. Retrieved from http://www.cranhr.ca/NPworkforcestudy.html

Koren, I., Mian, O., \& Rukholm, E. (2010). Integration of nurse practitioners into Ontario's primary health care system: Variations across practice settings. Canadian Journal of Nursing Research, 42, 48-69.

Kralewski, J., Dowd, B., Curoe, A., Savage, M., \& Tong, J. (2015). The role of nurse practitioners in primary healthcare. American Journal of Managed Care, 21, 366-371.

Kuo, Y. F., Chen, N. W., Baillargeon, J., Raji, M. A., \& Goodwin, J. S. (2015). Potentially 
preventable hospitalizations in Medicare patients with diabetes: A comparison of primary care provided by nurse practitioners versus physicians. Medical Care, 53, 776-83.

Liu, N., \& D'Aunno, T. (2012). The productivity and cost-efficiency of models for involving nurse practitioners in primary care: A perspective from queuing analysis. Health Services Research, 47, 594-613.

Liu, N., Finkelstein, S., \& Poghosyan, L. (2014). A new model for nurse practitioner utilization in primary care: Increased efficiency and implications. Healthcare Management Review, $39(1), 10-20$.

Liu, N., Ozen, A., \& Balasubramanian, H. J. (2013). Primary care practice design under case mix: Joint consideration of access to care and continuity of care. Retrieved from http://www.columbia.edu/ nl2320/doc/Practice\%20Design\%20under\%20Case\%20Mix_ $\% 20$ online\%20version.pdf

Marchildon, G.P. (2005). Health systems in transition: Canada. European Observatory on Health Systems and Policies, 7(3), 1-156. Retrieved from http://www.euro.who.int/document/e87954.pdf

Martin, K. E. (2000). Nurse practitioners: A comparison of rural-urban practice patters and willingness to serve in underserved areas. Journal of the American Academy of Nurse Practitioners, 12, 491-496.

Martin-Misener, R., Crawford, T., DiCenso, A., Akhtar-Danesh, N., Donald, F., BryantLukosius, D., Kaasalainen, S. (2010). A survey of the practice patterns of nurse practitioners in primary health care in Nova Scotia. College of Registered Nurses of Nova Scotia and Dalhousie University School of Nursing, Halifax, NS.

Martin-Misener, R., Donald, F., Kilpatrick, K., Bryant-Lukosius, D., Rayner, J., Landry, V., ... 
McKinlay, J. (2015). Benchmarking for nurse practitioner caseload and comparative analysis of nurse practitioner pay scales: Update of a scoping review. Report presented May 31, 2013. Updated from December 5, 2014 stakeholders meeting.

Martin-Misener, R., Harbman, P., Donald, F., Reid, K., Kilpatrick, K., Carter, N., ..., DiCenso, A. (2015). Cost-effectiveness of nurse practitioners in primary and specialized ambulatory care: Systematic review. British Medical Journal Open, 5(6). doi:10.1136/bmjopen-2014-007167

Mayo-Bruinsma, L., Hogg, W., Taljaard, M., \& Dahrouge, S. (2013). Family-centred care delivery: Comparing models of primary care service delivery in Ontario. Canadian Family Physician, 59, 1202-1210.

Medical dictionary online. (n.d.). Retrieved from http://medicaldictionary.thefreedictionary.com/acute+disease

Merriam-Webster's online dictionary. (n.d.). Retrieved from http://www.merriamwebster.com/dictionary/age

Merriam-Webster's online dictionary. (n.d.). Retrieved from http://www.merriamwebster.com/dictionary/gender

Merriam-Webster's online dictionary. (n.d.). Retrieved from http://www.merriam-webster.com/dictionary/socioeconomic

McKnight, P. E., McKnight, K. M., Sidani, S., \& Figueredo, A. J. (2007). Missing data: A gentle introduction. New York, NY: Guilford.

Mian, O., \& Koren, I. (2011). Primary healthcare nurse practitioner tracking study: The 2010 survey report. Centre for Rural and Northern Health Research, Laurentian University, Sudbury, ON. Retrieved from http://www.cranhr.ca/NPworkforcestudy.html 
Mian, O., Lacarte, S., \& Koren, I. (2012). 2012 nurse practitioner workforce tracking study. Centre for Rural and Northern Health Research, Laurentian University, Sudbury, ON. Retrieved from http://cranhr.ca/onlrpts.html\#NP12

Miller, D., Zantop, V., Hammer, H., Faust, S., \& Grumbach, K. (2004). Group medical visits for low-income women with chronic disease: A feasibility study. Journal of Women's Health, 13, 217-225.

Ministry of Health and Long-term Care (MOHLTC). (2011). Rural and northern health care report. Retrieved from http://www.health.gov.on.ca/

Morgan, P., Everett, C., \& Hing, E. (2015). Nurse practitioners, physician assistants, and physicians in community health centers, 2006-2010. Healthcare, 3, 102-107.

Morris, R., MacNeela, P., Scott, A., Treacy, P., \& Hyde, A. (2007). Reconsidering the conceptualization of nursing workload. Literature review. Journal of Advanced Nursing, $57,463-471$.

Muldoon, L., Dahrouge, S., Russell, G., Hogg, W., \& Ward, N. (2012). How many patients should a family physician have? Factors to consider in answering a deceptively simple question. Healthcare Policy, 7, 26-34.

Muldoon, L., Rayner, J., \& Dahrouge, S. (2013). Patient poverty and workload in primary care. Canadian Family Physician, 59, 384-90.

Murray, M., Davies, M., \& Boushon, B. (2007). Panel size: How many patients can one doctor manage? Family Practice Management, 1, 44-51.

Oritz, J., Wan, T. T., Meemon, N., Paek, S., \& Agiro, A. (2010). Contextual correlates of rural health clinics' efficiency: Analysis of nurse practitioners' contributions. Nursing Economics, 28, 237-244. 
Pallant, J. (2010). SPSS survival manual: A step by step guide to data analysis using SPSS (4 ${ }^{\text {th }}$ ed.). Berkshire, ENG: McGraw-Hill.

Parker, R., Forrest, L., Ward, N., McCracken, J., Cox, D., Derrett, J. (2013). How acceptable are primary health care nurse practitioners to Australian consumers? Collegian, 20, 35-41.

Phillips, R. L., Bazemore, A. M., \& Peterson, L. E. (2014). Effectiveness over efficiency underestimating the primary care physician shortage. Medical Care, 52, 97-98.

Poghosyan, L., \& Aiken, L. H. (2015). Maximizing nurse practitioners' contributions to primary care through organizational changes. Journal of Ambulatory Care Management, 38, 109117.

Poghosyan, L., Boyd, D., \& Knutson, A. R. (2014). Nurse practitioner role, independent practice, and teamwork in primary care. The Journal for Nurse Practitioners, 10, 472-479.

Poghosyan, L., Lucero, R., Rauch, L., \& Berkowitz, B. (2012). Nurse practitioner workforce: A substantial supply of primary care providers. Nursing Economics, 30, 268-274.

Poghosyan, L., Nannini, A., \& Clarke, S. (2013). Organizational climate in primary care settings: Implications for nurse practitioner practice. Journal of the American Association of Nurse Practitioners, 25, 134-140.

Poghosyan, L., Shang, J., Liu, J., Poghosyan, H., Liu, N., \& Bobbie, B. (2015). Nurse practitioners as primary care providers: Creating favourable practice environments in New York State and Massachusetts. Health Care Management Review, 40, 46-55.

Polit, F. D. (2010). Statistics and data analysis for nursing research ( $2^{\text {nd }}$ ed.). New Jersey, NJ: Pearson Education.

Polit, F. D., \& Beck, C. T. (2004). Nursing research: Principles and methods $\left(7^{\text {th }}\right.$ ed.). Philadelphia, PA: Lippincott. Williams \& Wilkins.

Potts, B., Adams, R., \& Spadin, M. (2011). Sustaining primary care practice: A model to 
calculate disease burden and adjust panel size. Permanente Journal, 15, 53-56.

Rayner, J. (2014). Ontario CHC panel size handbook v.3. Toronto, ON: Association of Ontario Health Centres.

Reay, T., Patterson, E. M., Halma, L., \& Steed, W. B. (2006). Introducing a nurse practitioner: Experiences in a rural Alberta family practice clinic. Canadian Journal of Rural Medicine, 11, 101-107.

Rhoads, J., Ferguson, L.A., \& Langford, C. A. (2006). Measuring nurse practitioner productivity. Dermatology Nursing, 18, 32-34.

Rich, E. R. (2005). Does RN experience relate to NP clinical skills? Nurse Practitioner, 30(12), 53-36.

Roots, A., \& MacDonald, M. (2014). Outcomes associated with nurse practitioners in collaborative practice with general practitioners in rural settings in Canada: A mixed methods study. Human Resources for Health (Electronic Resource), 12, 69.

Russell, G. M., Dahrouge, S., Hogg, W., Geneau, R., Muldoon, L., \& Tuna, M. (2009). Managing chronic disease in Ontario primary care: The impact of organizational factors. Annals of Family Medicine, 7, 309-318.

Sangster-Gormley, E., Canitz, B., Schreiber, R., Borycki, E., Frisch, N., Sawchenko, L., ... Swamy, M. (2012). A survey of nurse practitioner practice patterns in British Columbia. Victoria, British Columbia: University of Victoria. Retrieved from http://www.uvic.ca/hsd/nursing/assets/docs/news/np_practice_patterns.pdf Sangster-Gormley, E., Griffith, J., Schreiber, R., Borycki, E., Feddema, A., \& Thompson, J. (2015). Interprofessional collaboration: Co-workers' perceptions of adding nurse practitioners to primary care teams. Quality in Primary Care, 23, 122-126. 
Shortt, M., Hogg, W., Devlin, R., Russell, G., \& Muldoon, L. (2012). Estimating patient demographic profiles from practice location. Canadian Family Physician, 58, 414419.

Sloan, C., Pong, R., Rukholm, E., \& Caty, S. (2006). Nurse practitioner workforce survey and NPAO electronic registry project report. Centre for Rural and Northern health Research, Laurentian University, Sudbury, Ontario. Retrieved from www.cranhr.ca/pdf/NP_Registry_fin2006.pdf

Statistics Canada. (2015). Census data and definitions. Retrieved from http://www.statcan.gc.ca/pub/21-006-x/2008008/section/s2-eng.htm

Statistics Canada. (2013). Health status. Retrieved from http://www.statcan.gc.ca/pub/82-229x/2009001/status/int4-eng.htm

Swan, M., Ferguson, S., Chang, A., Larson, E., \& Smaldone, A. (2015). Quality of primary care by advanced practice nurses: A systematic review. International Journal for Quality in Health Care, 27, 396-404.

Tabachnick, B. G., \& Fidell, L. S. (2007). Using multivariate statistics $\left(5^{\text {th }}\right.$ ed.). Boston, MA: Pearson Education.

Thibeault, L. D. (2011). Nurse practitioner-led clinic in Thunder Bay. (DNP capstone project). The College of St. Scholastica, Ann Arbor, MI.

Tomblin Murphy Consulting Incorporated. (2004). Human health resource component. Recruitment and retention of primary health care nurse practitioners in Canada. Ottawa, ON: Canadian Nurses Association.

van Soeren, M., Hurlock-Chorostecki, C., Goodwin, S., \& Baker, E. (2009). The primary 
healthcare nurse practitioner in Ontario: A workforce study. Nursing Leadership, 22, 5872.

Venning, P., Durie, A., Roland, M., Roberts, C., \& Leese, B. (2000). Randomized controlled trial comparing cost effectiveness of general practitioners and nurse practitioners in primary care. British Medical Journal, 320, 1048-1053.

Wallace, E., Salisbury, C., Guthrie, B., Lewis, C., Fahey, T., \& Smith, S. (2015). Managing patients with multimorbidity in primary care. British Medical Journal, 350, 176. doi: http://dx.doi.org/10.1136/bmj.h176

Waszynski, C., Murakami, W., \& Lewis, M. (2000). Community care management. Advanced practice nurses as care managers. Care Management Journals, 2, 148-152.

Watson, D., Broemeling, A., \& Wong, S. (2009). A results-based logic model for primary healthcare: A conceptual foundation for population-based information systems. Healthcare Policy, 5(Special Issue), 33.

Watts, S., Gee, J., O’Day, M., Schaub, K., Lawrence, R., Aron, D., \& Kirsh, S. (2009). Nurse practitioner chronic illness care: The unique strengths of nurse practitioners applied to shared medical appointments/group visits. Journal of the American Academy of Nurse Practitioners, 21, 167-172.

Way, D., Jones, L., Baskerville, B., \& Busing, N. (2001). Primary health care services provided by nurse practitioners and family physicians in shared practice. Canadian Medical Association Journal, 165, 1210-1214.

Way, D., Jones, L., \& Busing, N. (2000). Implementation strategies: “Collaboration in primary 
care-Family doctors \& nurse practitioners delivering shared care": Discussion paper written for The Ontario College of Family Physicians. Retrieved from http://www.eicp.ca/en/toolkit/management-leadership/ocfp-paper-handout.pdf

Yoshida, H., Fenick, A., \& Rosenthal, M. (2014). Group well-child care: An analysis of cost. Clinical Pediatrics, 53, 387-394. 